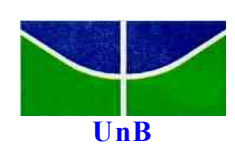

Universidade de Brasília

Faculdade de Educação Física

Programa de Pós-Graduação em Educação Física

\title{
O Projeto Centro de Iniciação Desportiva e as políticas esportivas no Distrito Federal: uma análise à luz dos direitos de cidadania
}




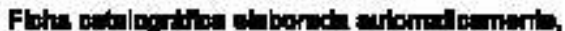

com 1os dados tomentibe pelo(a) autor(a)

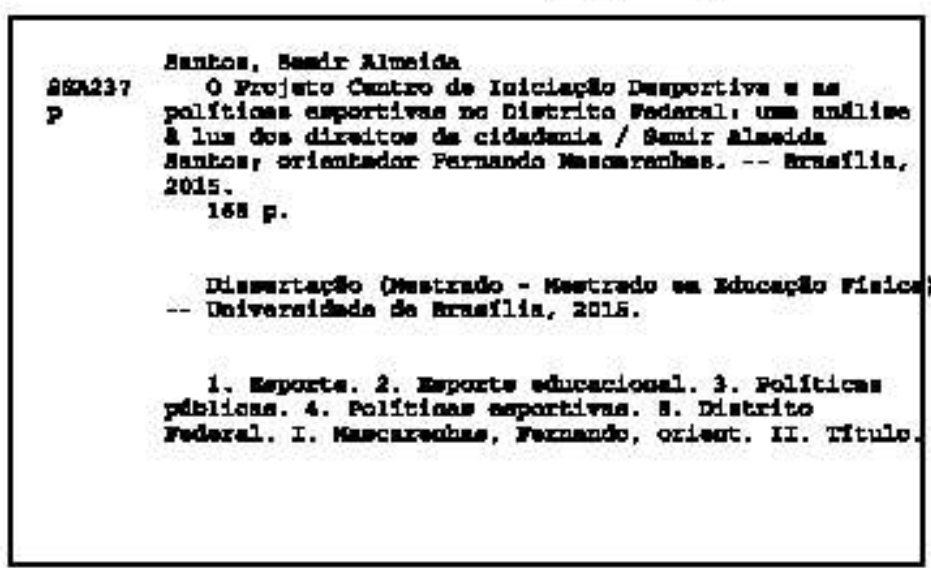


SAMIR ALMEIDA SANTOS

O Projeto Centro de Iniciação Desportiva e as políticas esportivas no Distrito Federal: uma análise à luz dos direitos de cidadania

Dissertação apresentada à Faculdade de Educação Física da Universidade de Brasília como requisito parcial para obtenção do grau de Mestre em Educação Física.

ORIENTADOR: PROF. DR. FERNANDO MASCARENHAS

BRASÍLIA, DF

2015 


\section{O Projeto Centro de Iniciação Desportiva e as políticas esportivas no Distrito Federal: uma análise à luz dos direitos de cidadania}

Dissertação apresentada à Faculdade de Educação Física da Universidade de Brasília como requisito parcial para obtenção do grau de Mestre em Educação Física.

Data de Aprovação: 10/12/2015

BANCA EXAMINADORA:

Prof. Dr. Fernando Mascarenhas Alves

Orientador

Universidade de Brasília

Prof. Dr. Pedro Fernando Avalone Athayde

Membro Interno

Universidade de Brasília

Prof. Dr. Roberto Liáo Jr.

Membro Externo

Secretaria de Estado de Educação do Distrito Federal

Prof. Dr. Arthur José Medeiros de Almeida

Membro Suplente

UNICEUB 


\section{DEDICATÓRIA}

Cresça. Independente do que aconteça. Eu não quero que você esqueça: gosto muito de você...

Aos meus filhos Davi e João Pedro.

Juntamente, o pedido de perdão pelo irrecuperável tempo que lhes subtraí. 


\section{AGRADECIMENTOS}

À minha esposa Eliane pelo amor, paciência e compreensão, em especial pela confiança e companheirismo. Desde o início e sempre.

Eu vi chover, eu vi relampear. Mas, mesmo assim, o céu estava azul...

Aos amigos Daniel Cantanhede, Pedro Tatu, José Montanha Soares, Juarez Sampaio, Roberto Liáo Jr., Zezão de Miranda, obrigado por iluminarem com seu companheirismo minha infindável formação humana, onde também navega, dialeticamente, minha formação acadêmica. Tê-los como amigos é um privilégio.

À minha família nuclear original, pai Francisco Gomes, mãe Heloísa, irmã Gabrielle e primos, tias e tios, que, para além de festejarem comigo a conclusão desta etapa, me dedicarem apoio e incentivo para esta formação por acreditarem em minha capacidade.

Aos professores e professoras da SEDF que de forma gentil e com olhar de esperança me receberam em suas escolas e Regionais de Ensino. Com eles, possuo o indelével compromisso de retornar este trabalho de forma digna e honesta.

Aos amigos e amigas da CEFDESC por contribuírem de forma gentil e solícita com esta pesquisa: Luís Maurício, José Oldair, Juarez Sampaio, Roberto Liáo, Rubens Memória, Elisa Pinheiro, Vênus Aragão, Mariana, extensivo aos tantos outros que outrora, ainda na DIDESC, alimentaram minha intenção de pesquisar as políticas públicas de esporte e lazer na SEDF.

Pelo mundo andei, pelo mundo andar...

Aos companheiros do Avante, Grupo de Pesquisa que, tamanha grandeza e estatura acadêmica, ultrapassa os limites da Universidade para, indubitavelmente, repercutir na práxis social de cada um e cada uma e seus(suas) pesquisadores(as).

Ao Lino Castellani Filho, que talvez nunca saberá da importância em minha trajetória de tê-lo como companheiro de Avante e amigo nas folgas acadêmicas.

Ao Fernando Mascarenhas pela paciência e companheirismo em relação às minhas demandas pessoais e familiares, sempre respeitando minha autonomia intelectual e provocando-me a romper meus limites.

Aos amigos acadêmicos da FEF, com menção especial ao Nadson Santana Reis, que me incentivou através de seu exemplo e bravura neste processo de formação.

Aos funcionários e professores da FEF, pessoas amigas que atravessaram todo meu processo de formação para o trabalho, formação acadêmica e formação humana no interior daquele espaço: David, Josino, Theodoro (in memorian), seu Marcos, Áurea, Glauco Falcão, e nos tempos atuais Raposo, Marcelo Húngaro e seus demais trabalhadores. Extensivo à Secretaria de Pós-Graduação: Quélbia, Thiago e Alba. 
Ao SINPRO-DF e sua diretoria colegiada, em especial a Rosilene Corrêa e Luciana Custódio, pelo companheirismo e ajuda incansável nas lutas necessárias.

À população do Distrito Federal que ajudou financiar esta pesquisa ao possibilitar o afastamento de minhas funções laborais de forma remunerada e para quem retorno este trabalho na intenção de contribuir com uma Educação Física e um esporte educacional mais democrático e humano.

Finalmente, Àqueles que em outro plano me ajudaram a trilhar esse caminho.

Ele bradou na aldeia, e aqui vai bradar. 


\section{Resumo}

O Projeto Centro de Iniciação Desportiva (CID) é uma política de esporte educacional organizada pela Secretaria de Educação do Distrito Federal e atende a estudantes da rede pública do DF que desejam aperfeiçoar-se em uma modalidade esportiva em seu contraturno escolar. Esta pesquisa propôs-se analisar os limites e possibilidades que esta política experimenta quanto a garantia dos direitos de cidadania, partindo do pressuposto que o esporte se apresenta como um satisfador intermediário das necessidades humanas básicas. Dessa forma, procurou discutir as perspectivas do Projeto, confrontando sua trajetória histórica, proposta pedagógica e seus marcos jurídico e institucional. Quanto ao seu delineamento, a pesquisa se desenvolveu a partir de uma abordagem qualitativa, apoiada em revisão de literatura, levantamento documental e realização de entrevistas semiestruturadas. Os dados obtidos foram discutidos a partir de uma perspectiva crítica de análise de políticas sociais, considerando os aspectos: configuração e abrangência; financiamento e gasto; gestão e controle social. Os resultados revelaram que o CID se aproximou em sua experiência histórica de uma lógica focalizada, utilitarista, seletiva e acrítica ao reproduzir um modelo pautado pelo esporte de alto rendimento. Entretanto, a proximidade com a lógica educacional tem permitido, especialmente nos últimos quatro anos, uma reorientação do CID em direção à garantia de direitos e democratização de sua gestão. Tal reorientação pode conferir ao CID um horizonte de transformação no sentido contra-hegemônico em tempos de pauperização e despolitização das políticas públicas.

\section{Palavras-chaves:}

Esporte; Esporte educacional; Políticas públicas; Políticas esportivas; Distrito Federal. 


\begin{abstract}
The Centro de Iniciação Desportiva Project (CID) is an educational sport policy organized in Brazil's Federal District Secretary of Education and caters to students from public school who wish to improve in a sport in your school hours. This research set out to analyze the limits and possibilities that this policy experience as a guarantee of citizenship rights, assuming that the sport is presented as an intermediary satisfier of basic human needs. Thus, we discuss the prospects of the Project, comparing their historical trajectory, pedagogical proposal and its legal and institutional frameworks. As for its lineation, the research was developed from a qualitative approach, based on literature review, documentary survey and conducting semi-structured interviews. The data were discussed from a critical perspective analysis of social policies, considering aspects: configuration and coverage; financing and spending; management and social control. The results revealed that the CID came in their historical experience in a focused, utilitarian, selective and uncritical logical when ruled by a guided model for high performance sport. However, proximity to educational logic has allowed, especially in the last four years, a reorientation of the CID towards the guarantee of rights and democratization of their management. Such reorientation may confer upon the CID a horizon of other-hegemony transformation, in times of impoverishment and despoliticization of public policy.
\end{abstract}

\title{
Keywords:
}

Sport; Educational sports; Public policy; Sports policies; Federal District. 


\section{LISTA DE FIGURAS}

Item

Página

Figura 1 - Pirâmide Esportiva prevista no Diagnóstico da Educação Física e Desportos do Governo Médici. 


\section{LISTA DE GRÁFICOS}

Item

Página

Gráfico 1 - Gasto com esporte realizado pelo governo federal entre 2003 e $2008 \ldots . .43$ 


\section{LISTA DE QUADROS}

Item

Página

Quadro 1 - Políticas de esporte educacional do Governo Federal. 38

Quadro 2 - PPA 2008/2011 92

Quadro 3 - PPA 2012/2015 94

Quadro 4 - Aspectos e indicadores de análise. 118

Quadro 5 - Modalidades do CID versus Modalidades dos Jogos da Juventude 123 


\section{LISTA DE ABREVIATURAS}

$\mathrm{CBC}$ Confederação Brasileira de Clubes

CBD Confederação Brasileira de Desportos

CBDE Confederação Brasileira de Desporto Escolar

CBF Confederação Brasileira de Futebol CEFDESC Coordenação de Educação Física e Desporto Escolar

$\mathrm{CF}$ Constituição Federal

CID Centro de Iniciação Desportiva

CND Comissão Nacional do Desporto

CNE Conferência Nacional de Esporte

COB Comitê Olímpico Brasileiro

$\mathrm{COI}$ Comitê Olímpico Internacional CONFEF Conselho Federal de Educação Física

CPB Comitê Paralímpico Brasileiro

CRE Coordenação Regional de Ensino CREF Conselho Regional de Educação Física

DIDESC Diretoria de Desporto Escolar e Educação Física DF Distrito Federal DODF Diário Oficial do Distrito Federal EAR Esporte de alto rendimento FIFA. Federação Internacional de Futebol FIEP Federação Internacional de Educação Física GDF Governo do Distrito Federal LDB Lei de Diretrizes e Bases da Educação Nacional LODF Lei Orgânica do Distrito Federal ME Ministério do Esporte 
MEC Ministério da Educação

MEEF Movimento dos Estudantes de Educação Física

OnG Organização não-Governamental $\mathrm{OP}$ .Orientação Pedagógica

OSCIP Organização da Sociedade Civil de Interesse Público PCdoB Partido Comunista do Brasil PDAD Pesquisa Distrital por Amostra de Domicílios PDAF Programa de Descentralização Administrativa e Financeira PELC Programa Esporte e Lazer na Cidade PMDB Partido do Movimento Democrático Brasileiro PMDF Polícia Militar do Distrito Federal PT Partido dos Trabalhadores PPA Plano Plurianual PST. Programa Segundo Tempo RA. Região Administrativa

RIDE Região Integrada de Desenvolvimento do Distrito Federal e Entorno

SEDEST Secretaria de Estado de Assistência Social e Transferência de Renda SEDF Secretaria de Estado de Educação do Distrito Federal Sesp Secretaria de Esporte do Distrito Federal SENAI. Serviço Nacional de Aprendizagem Industrial SESC Serviço Social do Comércio SSPDF Secretaria de Segurança Pública do Distrito Federal TCDF Tribunal de Contas do Distrito Federal

UE Unidade Escolar

UNESCO Organização das Nações Unidas para a Educação, Ciência e a Cultura 


\section{APÊNDICES}

Apêndice I - Roteiro de Entrevistas... 160

Apêndice II - Termo de Consentimento Livre e Esclarecido (TCLE) 162

Apêndice III - Termo de autorização para utilização do som de voz para fins de pesquisa. .164 


\section{ANEXO}

Anexo 1 - Carta de Aprovação do Comitê de Ética em Pesquisa da

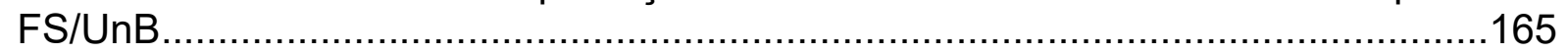




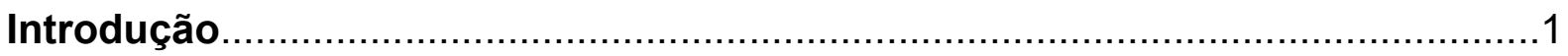

Capítulo 1 - 0 direito social, as necessidades humanas e o esporte................10

I - A política social no Brasil e as necessidades humanas............................11

a-) Direitos de cidadania e o esporte..........................................17

b-) O esporte no rol das necessidades humanas...............................21

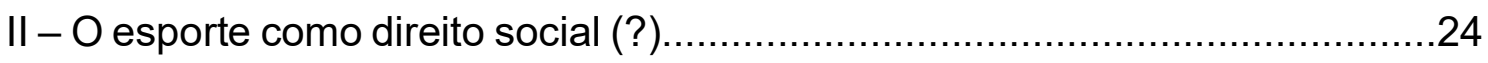

a-) Universalização, focalização e o direito ao esporte........................27

b-) Políticas sociais esportivas...............................................32

III - Políticas de esporte educacional no Brasil.........................................

Capítulo 2 - 0 direito ao esporte no Brasil...........................................46

$1^{\circ}$ Ato - A era pré-constitucionalização................................................47

$2^{\circ}$ Ato - O cenário da redemocratização.............................................59

$3^{\circ}$ Ato - A constitucionalização do esporte no Brasil.....................................64

$4^{\circ}$ Ato - Políticas de esporte educacional: sua história e concepção................75

Ato Final - Descortinando o direito ao esporte ..........................................84

Capítulo 3 - As políticas de esporte no Distrito Federal e o Projeto Centro de

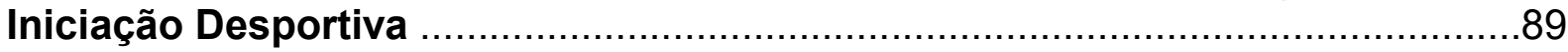

I - As políticas esportivas no Distrito Federal......................................90

a-) Mapa dos Programas/Ações de esporte educacional no DF ......................................................................................... 91

b-) Discutindo a presença do esporte educacional nas políticas esportivas do DF.....................................................................

II - O Projeto Centro de Iniciação Desportiva.......................................108

Capítulo 4 - Discutindo o Projeto CID ...............................................116

I - Configuração e abrangência....................................................120

II - Financiamento e gasto.......................................................... 131

III - Gestão e controle social...............................................................136

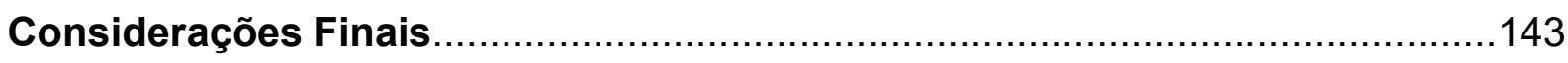




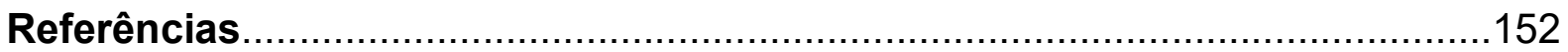

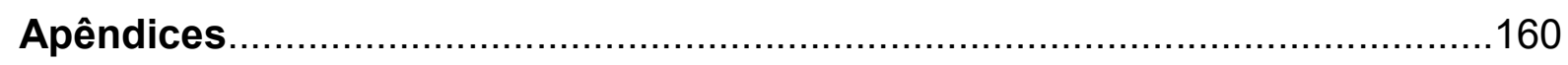

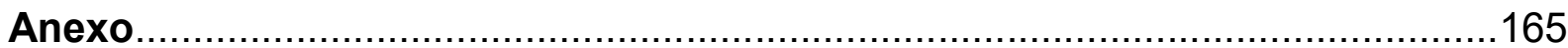




\section{Introdução}

Todo começo é difícil em qualquer ciência. [...] Acolherei, com maior satisfação, as manifestações da crítica científica. E, quanto aos preconceitos da chamada opinião pública, torno minha, agora como dantes, a máxima do grande Florentino: Segue teu rumo, não importa o que os outros digam! (MARX, 2014, p.15/19.)

Esta pesquisa imbuiu-se de estudar o Projeto Centro de Iniciação Desportiva (CID) da Secretaria de Educação do Distrito Federal (SEDF) e, como a partir das políticas esportivas do Distrito Federal (DF), sua experiência tem se consignado uma política de esporte educacional no Distrito Federal. O presente estudo se propôs analisar as possibilidades e obstáculos que esta política experimenta no que toca aos direitos de cidadania, partindo do pressuposto que o esporte se apresenta como um satisfador intermediário das necessidades humanas básicas (PEREIRA, 2008b). Dessa forma, procurou discutir as perspectivas do Projeto, confrontando sua trajetória histórica, proposta pedagógica (marco conceitual) e seus marcos jurídico/institucional, buscando mediações com a totalidade social em que se insere e apreendendo as contradições que subjazem ao seu percurso como política do Estado para o esporte educacional.

O CID foi criado em 1981, momento em que as políticas para a Educação Física (posto não se apresentarem, ainda, as demarcações do esporte - educacional, participação e rendimento - que vieram ocorrer após Constituição de 1988) encontravam-se sob a perspectiva, segundo Taffarel (2000) da busca da aptidão física e rendimento esportivo, pautados pelo "Diagnóstico de Educação Física/desportos no Brasil" de 1969/1970, realizado pelo governo cívico-militar de Médici. Percebendo a predominância e enviesamento desta possibilidade da cultura corporal (o esporte) nas aulas de Educação Física escolar, a autora alertou:

A afirmação da supremacia e predominância do Desporte sobre a Educação Física, visível nas opções em tratar o desporto como conteúdo de ensino nas escolas, sem dados e argumentações científicas, pedagógicas e éticas sobre esta supremacia, causam sérios problemas na formação das crianças e jovens (TAFFAREL, 2000, p. 22). 
Já segundo a Orientação Pedagógica mais recente do Projeto CID (2012), ele propõe-se a "oportunizar aos alunos da Rede Pública de Ensino do Distrito Federal o conhecimento técnico e tático de diferentes modalidades esportivas, buscando identificar diferentes aptidões e interesses e oportunizando a ampliação do processo de seleção e formação de futuros atletas" (SECRETARIA DE ESTADO DE EDUCAÇÃO DO DISTRITO FEDERAL [SEDF], 2012a).

Materializa-se através de aulas de modalidades esportivas diversas (dezessete, segundo a Coordenação de Educação Física e Desporto Escolar CEFDESC $^{1}$ ), cujo trabalho é desenvolvido pelos docentes da SEDF e coordenado, fiscalizado e avaliado pela CEFDESC com apoio institucional de estruturas gestoras descentralizadas denominadas Coordenações Regionais de Ensino (CREs), estas, incumbidas do controle administrativo sobre a vida funcional do docente, assim como da mediação entre o docente e a Unidade Escolar (U.E.), local onde a unidade do Projeto, denominada pólo, é sediada. As modalidades desenvolvidas pelo CID são: atletismo, badminton, basquetebol, capoeira, karatê, futebol, futsal, ginástica artística, ginástica rítmica, handebol, judô, natação, taekwondo, tênis de mesa, voleibol, luta olímpica e xadrez².

Em sua trajetória de mais de três décadas de existência, o Projeto CID atravessou períodos emblemáticos da trajetória política do esporte brasileiro como o Movimento Renovador da Educação Física ${ }^{3}$ e do esporte, a constitucionalização do direito ao esporte, a liberalização de suas políticas e sua institucionalização através da criação do Ministério do Esporte (ME), já no século XXI. Por conseguinte, têm

\footnotetext{
${ }^{1}$ É importante afirmar que a CEFDESC foi extinta pelo Decreto $N^{\circ} 36.828$ de 23/10/2015, e reduzida a uma Gerência denominada Gerência de Educação Física e Desporto Escolar, sem cargos subordinados. Tal iniciativa tomada pelo mandato do Governo Rodrigo Rollemberg é contemporânea ao encerramento deste trabalho, o qual não apresenta condições materiais repercuti-lo. Mas, baseado na análise histórica desenvolvida no decorrer desta pesquisa, é possível depreender que tal ação pode fragilizar o processo de democratização e sentido educacional que o CID tem vivenciado, especialmente nos últimos quatro anos. Outrossim, toda informação e/ou análise que tangencia ou se remete à participação da CEFDESC neste trabalho fora mantida de forma a preservar a autenticidade e fidedignidade dos dados encontrados no decorrer de sua elaboração.

2 Há ainda a atuação especializada do CID Paralímpico, que segundo Beltrame (2013) surge a partir de uma iniciativa de Educação Física inclusiva, o Programa de Reeducação e Orientação às Pessoas com Necessidades Educacionais Especiais (PRO-PNE). Inaugurado em 1999 no intuito de "oferecer uma prática regular de Educação Física Adaptada às Pessoas com Necessidades Especiais no Distrito Federal" (BELTRAME, 2013, p. 65/66), em 2006 o PRO-PNE torna-se o CID Paralímpico, o qual tem a intenção de oferecer atividades esportivas no contraturno escolar para os estudantes com diferentes necessidades educativas especiais matriculados na rede pública de ensino.

${ }^{3}$ O Movimento Renovador da Educação Física, segundo Bracht (1999), correspondeu à entrada das ciências sociais e humanas na área da Educação Física, o que permitiu a essa área do conhecimento uma análise crítica do paradigma da aptidão física no ensino desta disciplina.
} 
resistido a esses matizes político-normativos que the impingiram momentos de extrema dificuldades (QUIRINO et. al., 2012), certamente ameaçando sua continuidade e a efetivação do direito constitucional ao esporte educacional. Atualmente, o CID possui inserção em 13 das 14 CREs da SEDF, o que implica dizer que, à exceção de uma Região Administrativa (RA) está ao alcance de toda a rede pública de ensino do Distrito Federal.

Nesse cenário, diante da abrangência (estudantes da rede pública) e relevância no contexto das ações voltadas para o esporte educacional no DF, partimos do pressuposto que esta iniciativa representa em termos quantitativos a maior política pública e gratuita desta manifestação do esporte ${ }^{4}$ no DF. Diante dessa assertiva, buscamos avaliar se essa iniciativa do Estado responde ao pressuposto constitucional que avaliza o direito ao esporte educacional como prioridade, quais seus mecanismos, o referencial adotado na política e que lógica(s) se embute $(m)$ na materialização desta política. De tal maneira, a pergunta central da pesquisa questiona como o esporte educacional tem se configurado como objeto de políticas públicas no DF tendo em vista a experiência do CID.

A justificativa para esse estudo, portanto, é compreender se o Estado prioriza o esporte educacional no Distrito Federal conforme preza o que é estipulado na carta magna do país, ou seja, a promoção prioritária desta categoria de prática esportiva em detrimento das outras compreensões deste bem da cultura (participação e rendimento). Justifica-se ainda nesta pesquisa a intenção de, através da análise e discussão dos dados apresentados pela materialidade do Projeto, perceber se os direitos de cidadania na acepção de Coutinho (1999) estão sendo garantidos através destas políticas. O autor afirma que os direitos são conquistas históricas dos trabalhadores no âmbito da sociedade capitalista, pois estes precisaram conquista-los de forma a arrefecer as forças produtivas que avançam sobre a dignidade humana e alienam o trabalho produtivo. Dessa forma, a conquista da cidadania sempre caminhou junto com a universalização e democratização de direitos (COUTINHO, 1999).

Não obstante, no movimento dialético da história, o presente estudo pode vir a subsidiar as discussões no âmbito da sociedade política como instrumento de

\footnotetext{
${ }^{4}$ Expressão cunhada no processo da constitucionalização do esporte (TUBINO, 2010), que será discutida ao longo da dissertação.
} 
diagnóstico e discussão de suas ações para que se fortaleçam esta e outras possíveis políticas de esporte educacional.

O objetivo geral desta pesquisa foi analisar e avaliar a experiência do Projeto CID no Distrito Federal. Os objetivos específicos que auxiliaram a percorrer essa trilha foram: avaliar a experiência histórica e o modelo conceitual que tem orientado o Projeto CID; analisar a concepção de política e a articulação do CID com o conjunto das políticas de esporte no DF e; analisar a configuração do direito, o modelo de gestão e o financiamento do Projeto CID no DF.

A pesquisa procurou aproximar-se do referencial teórico histórico-dialético, que embasou todo o processo de investigação tanto na obtenção dos dados empíricos, assim como na posterior análise desses dados. Essa dinâmica fora fundamental para, ao tomar contato com sua aparência empírica, fosse realizado o movimento dialético a fim de chegar-se à compreensão da realidade, enxergando, ao final desse processo, a intervenção na realidade como práxis social.

A abordagem utilizada na pesquisa foi a qualitativa, segundo a concepção de Triviños (2008). O autor assevera que quando essa abordagem é aplicada juntamente à concepção do materialismo histórico-dialético, é capaz de se "assinalar as causas e consequências do problema, suas contradições, suas relações, suas qualidades, suas dimensões quantitativas, se existem e realizar através da ação um processo de transformação da realidade" (p. 125). O autor ainda ressalta que a pesquisa qualitativa na perspectiva do materialismo histórico dialético pode representar a "desreificação" dos fenômenos, do conhecimento e do ser humano, e também postula a rejeição da neutralidade do saber científico (TRIVIÑOS, 2008).

A proposta de análise adotada fora a proposta crítica de análise de Políticas Sociais de Boschetti (2009). A autora considera que a análise de políticas deve considerar os caracteres históricos, pautados nas condições que compõe as múltiplas determinações do fenômeno, permitindo dessa forma:

1- Analisar a política em sua totalidade, incorporando na análise os seus principais aspectos;

2- Revelar o caráter contraditório entre as normas e a materialização da política;

3- Mediar os determinantes estruturais que formam a política com as forças sociopolíticas que atuam tanto na sua formulação quanto execução. (BOSCHETTI, 2009). 
Esta proposta permitiu compreender a experiência atual do Projeto CID a partir de seu sentido histórico, de suas correlações com os determinantes estruturais no decorrer de seu desenvolvimento e as contradições inerentes deste processo. $O$ recorte cronológico da pesquisa compreendeu os dois últimos Planos Plurianuais do DF: 2008 a 2011 e 2012 a 2015.

Já seu delineamento adotou as técnicas da pesquisa documental, entrevista semiestruturada e pesquisa bibliográfica (TRIVIÑOS, 2008), esta última, também em auxílio da análise dos dados.

A pesquisa documental em fontes primárias, técnica privilegiada nas pesquisas sobre Políticas Públicas segundo Gil (2008), possibilitou o acesso ao acervo público documental respectivo ao Projeto tais quais suas leis, decretos, portarias, resoluções, pareceres (GIL, 2008). As unidades empíricas utilizadas nesta etapa da pesquisa foram os acervos físicos e/ou digitais da SEDF, Diário Oficial do Distrito Federal (DODF), Tribunal de Contas do Distrito Federal (TCDF), Portal da Câmara Legislativa, Portal do Ministério da Educação (MEC), Portal do Palácio do Planalto, Portal do Governo do Distrito Federal, Página eletrônica da SEDF, além de informações gentilmente cedidas pela própria CEFDESC e suas Gerências.

Por sua vez, a entrevista semiestruturada segundo Triviños (2008) permite ao pesquisador estabelecer uma relação dialógica com os sujeitos do processo a partir de questionamentos iniciais desenvolvidos através do acúmulo do pesquisador no processo investigativo, auxiliou-nos averiguar, in lócus, a impressão dos atores envolvidos no planejamento, execução, monitoramento e controle, assim como a prática social desenvolvida pelo Projeto através dos relatos desses atores. Este instrumento permitiu de forma singular enriquecer de determinações os aspectos e indicadores de análise da pesquisa. Os sujeitos entrevistados agruparam-se em três níveis de intervenção e operacionalização da política: os Gestores Centrais, aqueles que atuam no órgão de controle central do Projeto, a CEFDESC, os Gestores Locais, aqueles que atuam na gestão da Unidade Escolar onde o pólo de CID é sediado e os Professores, sujeitos que dão materialidade à política através de sua intervenção docente.

Portanto, a pesquisa contou com duas unidades de análise (CEFDESC, UE) e três categorias de sujeitos pesquisados, totalizando doze entrevistados assim distribuídos: três gestores centrais, quatro Gestores Locais e cinco Professores, todos 
identificados na pesquisa de forma genérica a fim de se manter seu anonimato. As unidades do CID pesquisadas neste trabalho distribuíram-se em três Coordenações Regionais de Ensino (CREs): CRE Ceilândia, CRE Guará e CRE Plano Piloto/Cruzeiro. Essa escolha se deu na intenção de apanhar a diversidade socioeconômica ${ }^{5}$ e abrangência de matrículas escolares ${ }^{6}$ na rede pública de ensino, esta indicativa dos beneficiários do Projeto. As Coordenações Regionais de Ensino (CREs) pesquisadas abrangem não apenas sua cidade nominal, mas diferentes Regiões Administrativas, conforme demonstrado a seguir:

- $\quad$ CRE Ceilândia - A cidade, conhecida como a RA IX, surgiu em decorrência da Campanha de Erradicação de Favelas (CEI) em 1971. Para esta cidade foram transferidas na ocasião de sua fundação cerca de 80.000 pessoas moradoras de aglomerações de alto risco socioeconômico espalhadas pelo DF. Com o aumento da migração para o Distrito Federal, o governo criou nesta RA novas áreas de ocupação urbanas, que hoje conta com aproximadamente 450.000 habitantes. É a RA com o maior número de matrículas na Rede Pública de ensino no DF, com aproximadamente 84.000 matrículas em todas as modalidades de ensino. Nesta CRE foram pesquisadas duas unidades do CID devido a sua dimensão e, portanto, seu potencial de abrangência. Os alunos atendidos pelo CID nas unidades pesquisadas residem na própria RA de Ceilândia (PROFESSOR 4; PROFESSOR 5).

- $\quad$ CRE Plano Piloto/Cruzeiro - Esta Coordenação Regional de Ensino envolve escolas de seis RAs do Distrito Federal: Plano Piloto (RA I), Cruzeiro (RA XI), Lago Sul (RA XVI) e Lago Norte (RA XVIII), Sudoeste-Octogonal (RA XXII) e Varjão (RA XXIII), dentre as quais apenas três foram pesquisadas pelo PDAD/2013 (Cruzeiro, Lago Norte e Varjão). O total de matrículas nas escolas dessa CRE corresponde a aproximadamente 39.100 matrículas, enquanto a população aproximada dessas seis RAs aponta aproximadamente para 360.000 habitantes. $^{7}$ Nesta CRE foram

\footnotetext{
${ }^{5}$ Fonte: Pesquisa Distrital por Amostra de Domicílios/2013 da Companhia de Planejamento do Distrito Federal (CODEPLAN). Disponível em http://www.codeplan.df.gov.br/areastematicas/desenvolvimento-regional/pmad/294-pdad-2013.html. Acesso em 21/07/2014.

${ }^{6}$ Fonte: Censo escolar/2013 da SEDF. Disponível em http://www.se.df.gov.br/educacao-df/rede-partconv/450-censo-escolar-2013.html. Acesso em 03/07/2014.

${ }^{7}$ Disponível em:

http://www.codeplan.df.gov.br/images/CODEPLAN/PDF/Pesquisas\%20Socioecon\%C3\%B4micas/TA BELA\%20RENDA\%20PER\%20CAPITA\%20E\%20POPULA\%C3\%87\%C3\%830\%20\%20CENSO\%202010.pdf. Acesso em 03/07/2014.
} 
pesquisadas duas unidades do CID, as quais atendem a alunos residentes no Varjão (PROFESSOR 1), Cruzeiro e Asa Sul (PROFESSOR 3).

- $\quad$ CRE Guará - A CRE do Guará atende a três RAs, a saber: Guará (RA X), Estrutural (conhecido também como SCIA - RA XXV) e SIA (RA XXIX). Com uma quantidade de matrículas de aproximadamente 18.700 estudantes, chama atenção a disparidade na renda per capita mensal entre duas de suas RAs: o Guará com R\$ $1.803,35$ e a Estrutural com $\mathrm{R} \$ 299,55^{8}$. A população da Cidade Estrutural segundo dados do PDAD/2013 é de aproximadamente 35.000 habitantes. Nesta CRE fora pesquisada uma unidade do CID, a qual, segundo o Professor 2 , atende estudantes residentes nas RAs do Guará e Estrutural.

Ainda sobre o delineamento da pesquisa cabe registrar que o levantamento bibliográfico constituiu importante instrumento para o resgate histórico das políticas de esporte educacional e seu enriquecimento conceitual a partir da produção já sistematizada, principalmente livros e artigos científicos (GIL, 2008). Essas fontes bibliográficas se constituíram em livros acadêmicos que versaram sobre temas como política social, esporte, lazer, política esportiva, assim como produções científicas diversas em formato de artigos, revisões sistemáticas e ensaios publicados nos mais periódicos.

A pesquisa fora realizada entre agosto de 2013 e outubro de 2015 no que diz respeito aos seus levantamentos bibliográficos, documentais e análise dos dados. Já as entrevistas foram realizadas entre dezembro de 2014 e setembro de 2015 . Foram seguidos neste trabalho todos os cuidados éticos previstos pelo Comitê de Ética em Pesquisa da Faculdade de Ciências da Saúde (CEP/FS) da Universidade de Brasília, o qual fora aprovado sob o registro CAAE 37686314.9.0000.0030, com base na Resolução 466/12 do CNS/MS.

Quanto à exposição, esta dissertação está organizada em quatro capítulos. No primeiro, ocorrem as primeiras aproximações à constituição dos direitos sociais e aos conceitos basilares da argumentação desenvolvida neste trabalho como direitos de cidadania (COUTINHO, 1999) e necessidades humanas básicas (PEREIRA, 2008b). Também neste capítulo ocorrem as primeiras mediações entre o tema esporte e os direitos de cidadania, as necessidades humanas e os direitos sociais, discutindo

\footnotetext{
8 Id., ibid.
} 
conceitos como universalização, focalização (PEREIRA; STEIN, 2010), o discurso mistificador do esporte (FLAUSINO; MASCARENHAS, 2012), e algumas possíveis mediações com as políticas esportivas (BUENO, 2008; MASCARENHAS, 2012; BRACHT; ALMEIDA, 2013; MATIAS, 2013; 2014).

No segundo capítulo será traçado um esboço da trajetória histórica do esporte no âmbito das legislações e políticas públicas. O texto atravessará os períodos em que o Estado inicia seu interesse na regulação do esporte na perspectiva de controle social e desenvolvimentismo nacional sob a perspectiva ufanista (CASTELLANI FILHO, 1988; 2008; MANHÃES, 2002; VERONEZ, 2005; BUENO, 2008), ações intensificadas nos períodos dos governos cívico-militares. Ao chegar no período da redemocratização, é realizado um esforço para compreender o cenário sociopolítico da época (MONTAÑO; DURIGUETTO, 2010; BEHRING; BOSCHETTI, 2011), o qual influenciou decisivamente na transformação do esporte em um direito constitucional (LINHALES, 1996; TUBINO, 2010; STAREPRAVO, 2011) e, por conseguinte, no surgimento da categoria esporte educacional em um processo que representou uma abstração e deu sentido à lógica da pirâmide esportiva (PIRES e SILVEIRA, 2007; SERON, 2013). Em última análise, este processo será analisado à luz de autores da tradição marxista (PEREIRA, 2008a; HÚNGARO, 2008; MONTAÑO, 2010; GRAMSCI apud COUTINHO, 2011).

No terceiro capítulo será realizado um panorama das políticas de esporte, especialmente o esporte educacional no Distrito Federal nos dois último Planos Plurianuais do Governo do Distrito Federal (GDF) - PPA 2008/2011 e PPA 2012/2015, período que corresponde a delimitação temporal desta pesquisa. Dessa forma, serão descritas as políticas esportivas presentes nestes documentos e em suas legislações complementares, com uma ênfase de análise nas políticas de esporte educacional (CARNEIRO, 2013). Outrossim, ao situarmos o Projeto CID neste arcabouço, descreveremos sua natureza institucional com algumas mediações em relação à sua materialidade: as entrevistas realizadas com Professores e um Gestor Central.

No quarto capítulo o Projeto CID é discutido com a base na proposta de análise de políticas sociais de Boschetti (2009). Os aspectos de análise propostos pela autora, enriquecidos pelos indicadores identificados na materialidade da política guiarão a discussão sobre seus resultados. Ao fim, as considerações deste pesquisador 
versarão sobre os limites identificados nesta política, suas arestas e os avanços advindos deste contraditório processo histórico. 


\section{Capítulo 1 - 0 direito social, as necessidades humanas e o esporte}

\begin{abstract}
A instituição dos direitos teria assim se condicionado ao processo de desenvolvimento da sociedade moderna de abstração dos contextos sociais, econômicos e culturais, como se a instituição dos direitos se desse fora dessas determinações. Também a teoria do direito natural, em que a universalidade assentou, por isso mesmo, na concepção metafísica do ser humano, tendo por força cogente, unicamente, princípios morais e éticos, que estariam latentes nas cartas constitucionais; e agora expressamente instituídos na Constituição de 1988. (SIMÕES, 2013, p. 212)
\end{abstract}

Neste primeiro Capítulo, iniciaremos o debate sobre a construção dos direitos sociais no Brasil e sua mediação com o esporte. Primeiramente, serão desenvolvidos os conceitos de necessidades humanas básicas e direitos de cidadania, cujo arcabouço conceitual atravessa todo o trabalho por situar o ponto de partida e o ponto de chegada da concepção de direitos e construção de políticas a qual esta pesquisa se filia, não apenas as esportivas, mas as políticas sociais como um todo.

Em seguida serão realizadas as primeiras mediações entre esses conceitos e o esporte, compreendido como um dos satisfadores das necessidades humanas básicas. Na esteira deste debate, refletiremos sobre o esporte como um suposto direito social, trazendo à cena as políticas sociais esportivas desenvolvidas na história recente de nosso país. Neste complexo articulado, iniciaremos a primeira aproximação junto ao esporte educacional, campo onde situa-se o objeto de estudo desta pesquisa. 


\section{A política social no Brasil e as necessidades humanas}

Simões (2013) afirma que os direitos sociais primam à garantia do valor da dignidade humana a partir de determinados bens sociais como a saúde, a previdência social e outros, distinguindo-os dos demais direitos fundamentais. Caracterizam-se por assegurar o direito de todo o coletivo de cidadãos a prestações do Estado por meio de benefícios e serviços (chamados por ele de direitos universais), ou ainda o acesso ao que o autor chama de direitos clássicos - trabalhistas, previdenciários e sindicais (SIMÕES, 2013).

Desta forma, eles distinguem-se dos direitos civis e direitos políticos, pois estes são direitos individuais e geram, portanto, obrigações negativas do Estado, onde este deve abster-se e respeitar seu livre usufruto. Cita como exemplo de direitos civis o direito à identidade, ir e vir, propriedade, compra e venda e os direitos políticos à crença religiosa, associação, reunião, liberdade de opinião. Os direitos sociais também são assegurados à população, segundo Simões (2013) em determinadas condições materiais (moradia, por exemplo) e espirituais (educação, por exemplo).

Por sua vez, Pereira (2008a) afirma que os direitos sociais são derivados dos direitos econômicos e culturais e referenciam-se no princípio da igualdade tendo como instituição responsável o Estado de Bem-Estar e, segundo a autora, tais direitos exigem a participação ativa do Estado para sua manutenção e fomento. Surgiram no século XX com a ampliação e desenvolvimento do proletariado, quando direitos derivados do direito ao trabalho entravam na pauta e afrontavam o desenvolvimento do Estado Liberal, rumando-o no sentido do Estado Social - Democrata (PEREIRA, 2008a). Esses direitos seriam além do trabalho o direito a saúde, educação, habitação e assistência social, que por sua vez requerem atuação e garantia por parte do Estado. A autora assevera que a garantia dos direitos sociais deve caminhar em direção à satisfação das necessidades básicas do ser humano.

A noção de necessidades humanas básicas se contrapõe à noção de "mínimos sociais", que segundo Pereira (2008b) é muito discutida no âmbito da proteção social. A autora assume a posição de distinção entre mínimo e básico; o primeiro assume a conotação de "menor, de menos, em sua acepção mais ínfima" (PEREIRA, 2008b, p. 26) enquanto básico "expressa algo fundamental, principal, primordial" (IDEM, p. 26), constituindo-se "pré-requisito ou as condições prévias suficientes para o exercício da 
cidadania em acepção mais larga" (IDEM, p. 26). Ela compreende que a essa distinção devem ser consideradas as discussões normativas, políticas e operacionais das políticas sociais. Tais políticas envolvem não apenas as de proteção social ${ }^{9}$, mas as políticas universais em sua totalidade.

É importante situar a priori que a confusão semântica entre os termos básico/mínimo alimenta uma discussão a respeito das políticas de proteção social, atingindo, por conseguinte, as políticas sociais. Pereira (2008b) compreende que os direitos sociais, pilares das políticas sociais, derivam-se das necessidades humanas básicas para além do conceito de "mínimos sociais". Para a autora, essa distinção explica as disputas teóricas e conceituais que aproximam os "mínimos sociais" das necessidades naturais. Contudo, estas necessidades naturais (relativas a sobrevivência orgânica) se encontram situadas previamente às necessidades sociais, estas respectivas a características da cidadania e bem-estar geral do homem, sem excluí-las ou sobreporem-se a elas, mas sim complementando-as. O conceito de "mínimos sociais", portanto, remetem a lógica liberal da assistência mínima, contrapondo-se a lógica progressista da assistência básica, mais ampliada. Segundo a autora, esta contradição corresponde ao cerne da questão nas políticas sociais, pois de sua interpretação suscitam respostas políticas e efetivas que devem ser problematizadas e levadas à discussão na implementação dessas políticas.

O conceito de mínimo social diz respeito à naturalização da divisão social em classes, entendimento da pobreza e demais mazelas sociais como entrave ao desenvolvimento do capitalismo e conferem às políticas de proteção social um caráter de assistencialismo e controle social (PEREIRA, 2008b). A autora defende que a política social deve caminhar em direção ao ótimo, no qual o cidadão é titular de seus direitos, sendo capazes de desenvolverem-se como cidadãos ativos, valorizando o princípio da equidade ${ }^{10}$ e sem reprodução das diferenças e injustiças sociais. E disso decorre o pensamento das necessidades básicas.

\footnotetext{
${ }^{9}$ A autora adere ao conceito de proteção social como as "regulamentações legais que garantem ao cidadão a seguridade social como direito" (PEREIRA, 2008b, p. 16). Deve ser garantida ao conjunto de cidadãos de maneira universal por meio de medidas, instituições, profissões, benefícios, serviços e recursos programáticos/financeiros. A autora não considera a seguridade social como uma "tutela" do Estado, mas sim como uma política pública: a política de proteção social, dentre as quais encontramse as políticas sociais.

10 Ainda que a autora não conceitue explicitamente o conceito de equidade nesta obra, entendemos através de seu percurso intelectual histórico que o sentido de equidade utilizado assume a compreensão marxiana: "de cada um segundo as suas capacidades e a cada um segundo as suas necessidades” (MARX, 1975 apud PEREIRA; STEIN, 2010, p. 113)
} 
Pereira (2008b.) denuncia um ideário conservador engendrado por um setor da sociedade chamado por ela de Nova Direita (neoconservadores e neoliberais) composto por intelectuais, políticos, gestores e executores das políticas públicas que privilegiam uma concepção subjetiva e relativa das necessidades humanas, vinculando-as a condições e possibilidades individuais que são dadas no interior de cada civilização, cultura e momento histórico. Esse pensamento, segundo a autora, relativiza as necessidades humanas - as quais são universais para todos os homens - e naturaliza a ordem social, responsabilizando individualmente cada cidadão pela sua condição e, por conseguinte, sujeitando a este cenário a eficácia e eficiência das políticas sociais.

\begin{abstract}
Em resumo, [...] uma sociedade ou uma economia podem ser ótimas, embora sejam ao mesmo tempo indignas e injustas, o que se choca com a concepção de ótimo aqui adotada, que não concebe critérios de bem-estar livre de conflitos de interesses, valores cívicos e éticos, nem a sociedade como agregado de indivíduos. Pelo contrário, parafraseando Sen (1976:15), a sociedade aqui é considerada como um todo orgânico, e não como a soma aritmética dos indivíduos que a compõe, e, por isso, as necessidades humanas, sendo sociais, não têm identificação com preferências dos membros dessa sociedade. (PEREIRA, 2008b, p. 33)
\end{abstract}

A autora se ampara na referência de Doyal e Gough (1991 apud PEREIRA, 2008b) para afirmar que as necessidades básicas são universais, comuns a todos os seres humanos em todos os tempos, lugares e culturas, rejeitando correntes políticas (o naturalismo defendido pela "Nova Direita"), ideológicas (o relativismo que atinge até mesmo pensadores de esquerda) e epistemológicas (os culturalistas de matriz fenomenológica) que relativizam ou subjetivizam as necessidades básicas. Tais autores afirmam, segundo Pereira (2008b):

[...] as necessidades básicas são objetivas, porque a sua especificação teórica e empírica independe de preferências individuais. E são universais, porque a concepção de sérios prejuízos, decorrentes da sua não-satisfação adequada, é a mesma para todo indivíduo, em qualquer cultura. (PEREIRA, 2008b, p. 68)

Após esse arcabouço que diferencia mínimo/básico no âmbito da política social, do reconhecimento da contradição existente entre as diferentes concepções e compreensões acerca da questão que envolve este conceito e da mediação entre as possibilidades emancipatórias e conservadoras embutidas neste tema, Pereira (2008b) considera existirem dois conjuntos de necessidades básicas universais 
concomitantes para que o ser humano se constitua como tal (diferenciando-se dos animais) e tornar-se um ser social: a saúde física e a autonomia. A primeira, por ser uma necessidade natural, que lhe permite viver; sua ausência ou perda concorre para uma descapacitação, segundo a autora, das demais possibilidades do ser humano, inclusive para exercer sua autonomia. Agora, à segunda, para satisfazer-se, são necessários conteúdos humano-sociais, ou a práxis humana, considerando ontologicamente o trabalho a atividade primordial que diferencia os homens dos animais. Pelo fato do trabalho requerer a intencionalidade de sua ação, este se constitui parte fundamental e necessária a sua existência, afinal, "os homens são mais do que os seus gens biologicamente condicionam" (PEREIRA, 2008b, p. 70). Por conseguinte, a autonomia seria o elemento que permite ao homem ultrapassar esse limite biológico.

Destarte, a autora alerta que esta autonomia não assume a conotação simplória e equivocada de liberdade de ação frente as escolhas individuais, crenças ou objetivos de cada um, mas sim "ser capaz de eleger objetivos e crenças, valorá-los e sentir-se responsável por suas decisões e por seus atos" (PEREIRA, 2008b, p. 71). Esta autonomia contrapõe-se, alerta a autora, a tendência liberal de imputar à individualidade de cada ser a possibilidade de autogerir-se em direção ao seu próprio desenvolvimento:

\footnotetext{
Resulta claro, pois, que essa noção liberal de autonomia ou de liberdade é insustentável na prática, pois o indivíduo por si só jamais desenvolverá as suas potencialidades. A ação individual, dizem Doyal e Gough, é social, na medida em que sempre é aprendida com outros e é por estes reforçadas [...] Mesmo Robinson Crusoé "já sabia ser tão laborioso [e racista!] porque já lhe haviam ensinado" (1991:60). (PEREIRA, 2008b, p. 72. Observação em colchetes original)
}

Compreendendo que a saúde física e a autonomia devem ser realizadas e atendidas em um contexto coletivo, o qual envolve os poderes públicos e a sociedade, ela advoga que estes devem ser alvos primordiais de políticas públicas universais, pois representam um direito fundamental de todos. Ambas devem ser satisfeitas concomitantemente e constituem condição prévia para que não ocorram prejuízos a participação social e libertação do ser humano da opressão, contribuindo para a participação das pessoas na vida social e na cultura, com capacidade de intervenção crítica nesse meio com a possibilidade de melhorá-lo ou transformá-lo. 
Pereira (2008b) esclarece que existem condições primordiais, as quais podem se traduzir em bens, serviços, atividades, relações, medidas ou políticas fundamentais, chamadas de satisfiers (ou satisfadores) para que sejam atendidas as necessidades básicas universais. Estes satisfadores são desdobramentos da experiência humana em sua práxis social que possibilitam o caminhar em direção a qualidade ótima de atendimento às necessidades humanas básicas. Estes, por sua vez, são também denominados necessidades intermediárias, agrupadas por Doyal e Gough (apud PEREIRA, 2008b.) em onze categorias hierarquicamente posicionadas: alimentação nutritiva e água potável; habitação adequada; ambiente de trabalho desprovido de riscos; ambiente físico saudável; cuidados de saúde apropriados; proteção à infância; relações primárias significativas; segurança física; segurança econômica; educação apropriada; segurança no planejamento familiar, na gestação e no parto.

Embora as necessidades humanas sejam universais, essas pré-condições para sua satisfação não o são, de acordo com a autora, pois há uma enorme diversidade no cenário socioeconômico, cultural, político e de desenvolvimento civilizatório que possibilitam a determinados grupos sociais aproximarem-se do nível ótimo de satisfação dessas necessidades mais do que outros. Mas, no contexto do capitalismo monopolista que vivenciamos, sob a égide neoliberal e no momento de desconstituição de direitos, as políticas sociais em seu apanhado geral não atendem aos mínimos pressupostos para que os seres humanos, de forma universal, sejam capazes de terem atendidas as suas necessidades humanas básicas.

Para ilustrar tal assertiva, Matias (2013) pondera que o corte nos gastos sociais intensificados após o período da Reestruturação Produtiva e Contra-Reforma do Estado ${ }^{11}$, somados ao avanço do capital frente ao fundo público e a monetarização das políticas sociais, além de degradá-las, reduziu o atendimento às necessidades humanas. A redução da política social ao conceito de política de combate à pobreza destitui, segundo o autor, as ações que garantem direitos, substituindo-as pela

\footnotetext{
11 Reestruturação Produtiva e Contra-Reforma do Estado representaram as estratégias de ajuste das políticas sociais e econômicas do Estado e sua reorganização político-institucional diante do deliberado esgotamento das políticas de proteção social do estado de bem-estar social (welfare state) e manutenção das taxas de lucro a partir da crise do capital na década de 1970 (MONTAÑO; DURIGHETO, 2010; BEHRING; BOSCHETTI, 2011). Tais conceitos, fundamentais para a compreensão do desenvolvimento histórico das políticas sociais a partir de 1970 serão desenvolvidos com maior acuidade no Segundo Capítulo - O direito ao esporte no Brasil.
} 
monetarização de benefícios ${ }^{12}$. Essa monetarização, que é descrita pelo autor como a inserção das políticas sociais na lógica da acumulação de capital, acontece porque tais políticas geram para o capitalismo mais pessoas para consumir os produtos do mercado, por conseguinte, mais pagadores de impostos. Isso se dá em virtude do caráter regressivo de arrecadação tributária no país: o consumo interno de mercadorias engendrado pelos benefícios sociais monetários das políticas sociais de combate à pobreza aumenta a arrecadação sobre os impostos já existentes que incidem sobre o consumo, retornando o investimento ao próprio Estado e alimentando assim a acumulação através do avanço da classe burguesa sobre o fundo público. Esta ação reforça a lógica de quem tem menos paga mais (SPOSATI, 2011 apud MATIAS, 2013).

Dessa forma, Matias (2013) argumenta que o salário da classe trabalhadora, antes liberado para o consumo de bens, custeia somente as necessidades fisiológicas dos seres humanos, e apenas quando há alguma sobra esta fica disponível para obtenção dos satisfadores histórico-culturais. Isso agrava a situação daqueles que dependem do trabalho para sobreviver. Assim, o acesso aos satisfadores sociais de forma mais ampla se tornam tão mais acessíveis àqueles que podem pagar por eles, dando a esta fração da sociedade melhores condições de acesso aos satisfadores de suas necessidades básicas.

As políticas focalizadas constituem-se peça chave para reforçar esta lógica, pois segundo o autor, apresentam-se como alternativa mais intensiva ao desmonte da proteção social e ao rompimento com as políticas sociais e econômicas de Welfare State (pleno emprego e universalidade da proteção social). O movimento desenvolvido para subjugar as políticas sociais em políticas de combate à pobreza ajuda a circular mais dinheiro através dessa política monetarista e desmontando a proteção social, dificultando o atendimento às necessidades básicas.

As medidas de alívio da pobreza são ampliadas, como alternativas ao desmonte de uma proteção intensiva em segurança social. As políticas focalizadas agem de forma a garantir a reprodução do capital, legitimando as desigualdades existentes e amenizando os problemas sociais (PEREIRA, 2011a). As necessidades humanas são rebaixadas ao mínimo, para diminuir

\footnotetext{
12 Matias (2013) cita como exemplo de monetarização das políticas o Programa Bolsa Família do Governo Federal, o qual ao transferir renda para a fatia mais desassistida da população permite a essa população sua inserção no mercado de consumo, atraindo investimento e lucros para os controladores do capital financeiro.
} 
os gastos sociais e aumentar o investimento em setores de acumulação capitalista (PEREIRA; STEIN, 2010). (MATIAS, 2013, p. 51)

Disso decorre que há limites para a efetiva consolidação dos direitos sociais cujos limites são colocados, conforme demonstra Matias (2013), frente às circunstâncias históricas e possibilidades concretas dos atores que compõe o todo social.

O pressuposto das necessidades humanas aqui desenvolvido norteia nossa compreensão de políticas sociais em sua legítima direção/intencionalidade, devendo apontar para a efetiva democratização e atendimento à sociedade, na construção e no exercício da cidadania. Nesse sentido, é importante estabelecer mediações entre o esporte como potencial instrumento para a cidadania e satisfação das necessidades humanas, na intenção de situar este produto da humanidade no âmbito das políticas sociais contemporâneas. Esse movimento procuraremos realizar a seguir.

\section{a) Direitos de cidadania e o esporte}

Coutinho (1999) lança luz ao conceito de cidadania situando-a como fruto de um processo histórico e conquista das classes subalternas. Ao fazê-lo, articula esse conceito ao de democracia. Esta, para o autor, representa a soberania popular através da presença de condições sociais e institucionais que possibilitam ao conjunto de cidadãos a participação ativa no controle da vida social. Apesar de diferentes definições atribuídas a este conceito no decorrer da história, o autor ressalta que cidadania representa uma conquista e não uma coisa dada, posta:

Cidadania é a capacidade conquistada por alguns indivíduos, ou (no caso de uma democracia efetiva) por todos os indivíduos, de se apropriarem dos bens socialmente criados, de atualizarem todas as potencialidades de realização humana abertas pela vida social em cada contexto historicamente determinado. [...] A cidadania não é dada aos indivíduos de uma vez para sempre, não é algo que vem de cima para baixo, mas é resultado de uma luta permanente, travada quase sempre a partir de baixo, das classes subalternas, implicando um processo histórico de longa duração. (COUTINHO, 1999, p. 42) 
Coutinho (1999) destaca o sociólogo britânico T.H. Marshall (1967 apud COUTINHO, 1999) como o precursor da atual compreensão de direitos de cidadania quando definiu três níveis de direitos básicos que constituem determinações modernas da cidadania, realizando-o em uma perspectiva histórico-cronológica a partir do processo de construção dos direitos de cidadania britânicos: os direitos civis (direito à vida, à liberdade e ir-e-vir, por exemplo), os quais são prévios aos direitos políticos (votar e ser votado, direito de associação e organização), que por sua vez abrem passagem para os direitos sociais (representados pela educação universal, saúde, habitação, previdência, assistência social). Estes últimos, acabaram se consolidando no contexto do capitalismo contemporâneo a partir das conquistas obtidas no Welfare State ou seja, políticas de bem-estar ${ }^{13}$ (COUTINHO, 1999).

Coutinho (1999) assevera que os direitos são fenômenos sociais, resultado da história e da luta dos trabalhadores. As demandas sociais, que antecedem os direitos apenas são satisfeitas, diz o autor, quando assumidas pelas instituições que asseguram uma legalidade positiva, ou seja, o Estado social.

\begin{abstract}
Embora possa parecer óbvio, não é desnecessário lembrar que os direitos sociais, talvez ainda mais do que os direitos políticos, são igualmente uma conquista da classe trabalhadora. E não é desnecessário porque as políticas sociais - ou seja, o instrumento pelo qual se materializam os direitos sociais são muitas vezes definidas sem que esse fato seja levado em conta. (COUTINHO, 1999, p. 51)
\end{abstract}

Por isso, a ampliação da cidadania e o processo (permanente) de construção de direitos são antagonistas à lógica do capital, afirma o autor. Assim, há uma contradição elementar entre cidadania e classe social, pois, "a divisão da sociedade em classes constitui limite intransponível à afirmação consequente da democracia" (COUTINHO, 1999, p. 53). Ele avalia que esta contradição se manifesta como um processo, usando o exemplo dos direitos sociais: o capitalismo moderno resiste a implantação e ampliação desses direitos, sendo esporadicamente forçado a recuar e realizar concessões, mas sem nunca deixar de manipulá-los a seu favor. Em certos casos, como no momento atual da crise de Reestruturação Produtiva e a ContraReforma que vivemos, até mesmo suprimi-los.

\footnotetext{
13 Welfare state, segundo Pereira (2011), corresponde ao modelo de intervenção do Estado na economia de forma a expandir o setor público e garantir sistemas de proteção social, culminando na combinação de fatores que permitiam a manutenção do pleno emprego, fortalecimento de políticas sociais e expansão da economia.
} 
Ele ressalta como que no decorrer da história do Capitalismo desde a época de Marx até chegar a modernidade ocorreram avanços e retrocessos na ampliação da cidadania. A leitura de Marx que à sua época (século XIX) considerava o Estado um "comitê executivo" para gerir os negócios da burguesia partia da ausência de direitos civis e políticos. Posteriormente, à época e Gramsci (início do século XX), já havia a possibilidade de organização dos trabalhadores e do trabalho, ou seja, direitos civis e políticos conquistados através da chamada "guerra de posição" (COUTINHO, 1999), a qual possibilitava a transformação da sociedade, e a ampliação de direitos. Mais adiante na história, a partir da instauração do Welfare State, o qual inaugurou os direitos sociais na sociedade britânica e perdura até a modernidade, a batalha pela conquista da cidadania sempre vislumbrou a universalização e democratização de direitos. O objeto deste processo, segundo Coutinho, é a emancipação humana.

[...] é preciso conceber a modernidade também pelo ângulo da ampliação e da universalização da cidadania, ou seja, concebê-la como uma época histórica marcada pela promessa da plena emancipação do homem de todas as opressões e alienações de que tem sido vítima, a maioria das quais produzidas e reproduzidas precisamente pelo capitalismo. (COUTINHO, 1999, p.58)

Tal assertiva também é corroborada por Tonet (2005) $)^{14}$. Ele acredita que a efetiva democracia e cidadania incorrem em seu sentido universal paralelamente à conquista do homem por sua emancipação. Mas não apenas a emancipação política, que para o autor remete-se apena a dimensão jurídico-política e não social, contexto no qual os homens tem sua força de trabalho subsumida às leis do mercado. $A$ reprodução da desigualdade social e a condição de alienação do homem representa uma impossibilidade no exercício da cidadania. A emancipação humana, segundo o autor, até mesmo transcende a cidadania, pois representa "uma forma de sociabilidade na qual os homens sejam efetivamente livres" (TONET, 2005, p. 4), supondo a completa erradicação do capital e todas as suas categorias.

Athayde (2014), por sua vez, nos permite compreender como este conceito de cidadania estabelece mediações com o esporte, este, uma construção social da humanidade. O autor parte do pressuposto de que a ampliação e consecução dos direitos de cidadania estão diretamente integradas ao atendimento das necessidades

\footnotetext{
14 Disponível em http://ivotonet.xpg.uol.com.br/arquivos/CIDADANIA OU EMANCIPACAO HUMANA.pdf. acesso: 03/03/2015
} 
humanas e sociais, frisando que os direitos sociais e individuais estabelecem uma relação dialética: este segundo, associado aos direitos políticos e civis, dão sustentação aos direitos sociais.

Athayde (2014) compreende a mercantilização do esporte como um entrave para que este se configure, nas palavras do autor, um satisfier das necessidades básicas do ser humano:

\begin{abstract}
Assim, uma vez que todos os fenômenos sociais podem e devem se transformar em mercadoria dentro da irracionalidade que orienta a sociedade capitalista, o esporte contemporâneo - até mesmo pelas suas características intrínsecas - acaba por se submeter a essa condição. É importante notar que a mercantilização do esporte guarda em si equivalência tanto com o processo de alienação do trabalho humano, quanto com a reificação das relações sociais, descortinadas por Marx nos seus estudos sobre o fetichismo da mercadoria. (ATHAYDE, 2014, p. 97, grifos originais)
\end{abstract}

O movimento da história que atualmente apanha o esporte como uma mercadoria subjuga o direito a este não como um direito civil (ou mesmo social), mas sim um "direito do consumidor". O autor ressalta que a transição do amadorismo para o profissionalismo, catapultados pela influência dos Jogos Olímpicos da era moderna (fundado em 1896) auxiliaram no processo de mercantilização do esporte, ressaltando os dizeres de Netto e Braz (2009, apud ATHAYDE, 2014) que todas as coisas e relações sociais no modo de produção capitalista são altamente permeáveis à lógica da mercantilização.

Athayde (2014) admite que o esporte, como satisfier das necessidades básicas humanas deva ser oferecido e gerenciado, no âmbito das políticas públicas, de forma a consubstanciar experiências ricas e humanizadoras, as quais propiciem aprendizados reais e configurem o papel educativo do Estado como ente promotor da emancipação humana:

Admitindo o esporte como um satisfador universal (necessidade intermediária) de direitos de cidadania, é inconcebível que o Estado, num programa ou projeto socioesportivo, promova um espetáculo que tenha por conteúdo alguma expressão da cultura mercantilizada e alienante. (ATHAYDE, 2014, p. 100)

Diante desta tarefa política de construir um esporte pautado pelo princípio do direito de cidadania, que é cotidiana, histórica e pertence (de acordo com COUTINHO, 1999) às classes que buscam a ampliação de direitos, procuraremos a seguir compreender como o esporte se apresenta na lista das necessidades humanas. 


\title{
b) 0 esporte no rol das necessidades humanas
}

Quando Doyal e Gough (1991 apud PEREIRA, 2008b) ponderam que há elementos satisfadores essenciais para as necessidades humanas básicas, diversos componentes presentes na cultura contemporânea podem ser elencados como instrumentos para obtenção dessas duas necessidades basilares que são universais e indistintas para todos os seres humanos: a saúde física e a autonomia. Quando postulamos o esporte na condição de satisfier das necessidades humanas, assumimos como pressuposto sua perspectiva de construto social como bem ponderou Castellani Filho (2008), uma resposta que o ser humano deu, em determinado momento de sua história, para atender as suas necessidades sociais e civilizatórias.

Isso vai além da compreensão reducionista que o apanha simplesmente como uma atividade ou prática motora/corporal, perspectiva que nas palavras de González (2005) corresponde a uma atividade

\begin{abstract}
a) orientada a comparar um determinado desempenho entre indivíduos ou grupos; b) regida por um conjunto de regras que procuram dar aos adversários iguais condições de oportunidades para vencer a contenda e, dessa forma, manter a incerteza do resultado e c) com essas regras institucionalizadas por organizações que assumem (exigem) a responsabilidade de definir e homogeneizar as normas de disputa e promover o desenvolvimento da modalidade, com o intuito de comparar o desempenho entre diferentes atores esportivos. (GONZÁLEZ, 2005, p. 170)
\end{abstract}

Esta atividade humana é entendida em nossos pressupostos como elemento da cultura corporal (COLETIVO DE AUTORES, 1992), conceito que confere intencionalidade e historicidade as atividades ginásticas, aos jogos, a dança, as lutas e o próprio esporte. Na concepção de cultura corporal, para os autores, os praticantes de esporte (ou qualquer uma de suas outras atividades) têm em sua expressão corporal uma linguagem, isso quer dizer, uma intencionalidade produzida por sua consciência social a partir de significações objetivas que dão o sentido a essa prática, no âmbito da subjetividade. Por sua vez, essas significações não são eleitas unilateralmente pela subjetividade, mas sim interpenetram dialeticamente as significações socialmente dadas a esta atividade. Isso quer dizer que o esporte em si, como uma expressão dialética da linguagem corporal, possui um arcabouço de 
valores que vão muito além da prática física sistematizada por um conjunto de regras específicas $^{15}$.

No âmbito das necessidades humanas, Pereira (2008b) citando Doyal e Gough afirma que a prática física é um atributo para que os seres humanos atinjam sua autonomia no sentido de agência, pois a mesma contribui para que o indivíduo assuma para si a responsabilidade sobre sua própria ação:

Trata-se, por conseguinte, do "repertório singular de atividades físicas e mentais - exitosas ou não - que compõe a história de como temos chegado a ser o que somos" (Doyal e Gough, 1991; 53), o qual quedará prejudicado se houver um déficit em três atributos: saúde mental, habilidade cognitiva e oportunidade de participação (Gough, 1998:53) (PEREIRA, 2008b, p. 71, grifos originais).

A autonomia desenvolvida através da própria experiência corporal de cada indivíduo é compreendida pelos autores como elemento a ser satisfeito no caminho para a autonomia como substância da plenitude humana. O esporte pode ser inserido nesse processo como satisfier, já que incute em sua prática elementos que permitem não apenas a experiência da prática física com autonomia individual, mas a tomada de decisões envoltas em um arcabouço de regras, normas e condutas tanto específicas como sociais, constituindo-se uma complexa e diversa atividade da cultura corporal, hoje difundida amplamente mundo afora.

Nesse sentido, essa atividade humana (o esporte) pode inserir-se como instrumento ou estratégia para satisfazer algumas das necessidades intermediárias apontados pelos autores, em virtude de sua possibilidade como prática física, prática lúdica, prática social, prática de educação ou mesmo prática econômica. Dentre elas podemos citar a incidência direta do esporte sobre as necessidades intermediárias apontadas por Doyal e Gough (apud PEREIRA, 2008b) respectivas ao ambiente físico saudável, cuidados apropriados de saúde, proteção à infância, relações primárias significativas, segurança física, segurança econômica, educação apropriada. Cabe

\footnotetext{
${ }^{15}$ Considero importante frisar que o desenvolvimento histórico do esporte enquanto construção humana apesar de sempre estar carregado de intencionalidades que afirmam os interesses da classe burguesa, não se pode abdicar da contradição colocada quando este é também apropriado, no bojo de sua história, por intencionalidades e interesses populares, democráticos e progressistas. Tal atividade, portanto, também foi apropriada e sistematizada não somente pela cultura que o enxerga como instrumento de reprodução social, mas também por aqueles que visam sua transformação no sentido da emancipação humana, tendo em vista possuir tamanho respaldo social a ponto de ser apropriado e reproduzido em diversas culturas e contextos.
} 
destacar uma passagem de Doyal e Gough ao discorrer sobre a necessidade de proteção à criança, através da necessidade de novas experiências que fomentem seu desenvolvimento cognitivo, social e emocional: "o jogo é um meio fundamental através do qual as crianças exercem esta espécie de primeira exploração e conhecimento" (PEREIRA, 2008b, p. 79).

Carneiro (2013) corrobora a concepção que o acesso ao esporte se constitui uma necessidade intermediária, pois afirma que este é um produto da cultura humana - uma prática física da cultura corporal - que possibilita o acesso à melhoria das condições gerais de vida, da saúde e da cidadania. O autor cita Melo (2004 apud CARNEIRO, 2013) para corroborar esse raciocínio:

Concebemos o acesso/permanência a práticas corporais como dimensão da cidadania, por relacionar-se com a tarefa de socialização da produção humana e não com a apropriação privada ou por pequenos grupos da produção de riquezas, seja material ou cultural. A Educação Física e os esportes se inserem no campo dos bens culturais, indispensáveis à condição de ser cidadão, embora não suficientes. Com isso, o constante evocar de ações cidadãs nesse campo podem estar indicando um esvaziamento da dimensão política da cidadania de enfrentamento da ordem excludente do capitalismo. Assim, de bandeira de luta contra a organização excludente da sociedade capitalista, objetivando denunciar o acesso/permanência desigual aos bens produzidos pela humanidade, bem como sua apropriação privada, a cidadania torna-se simples palavreado vazio. (MELO, 2004, p. 119 apud CARNEIRO, 2013, p.82)

Todavia, Carneiro (2013) pondera que o elemento principal para que essa possibilidade se efetive são as políticas públicas aliadas a não configuração deste direito como uma mercadoria, concepção que acaba por diferenciar entre as classes sociais o acesso e prática deste bem cultural. Athayde (2014) também adere a esse raciocínio, considerando o esporte como uma necessidade intermediária, destacando a relevância da universalização das políticas sociais e da ampliação da cidadania neste processo:

Ademais, o atendimento das necessidades humanas básicas e a ampliação e universalização dos direitos de cidadania mantêm aceso o lume da expectativa de que as possibilidades que a modernidade abriu para a humanidade - as generosas promessas de emancipação que ela criou - se realizem. Ao mesmo tempo, em que abrem caminho para o arrefecimento da tendência de submeter a existência social às escolhas impostas pela força cega e hegemônica que a domina, sobretudo aquela exercida pelo mercado. (ATHAYDE, 2014, p. 57) 
Após essa primeira aproximação do esporte à concepção de necessidades humanas, é importante refletir sobre as políticas de esporte junto aos conceitos que decorrem da ampliação de cidadania, afim de situá-las na perspectiva de atendimento às necessidades humanas. Esse movimento será realizado a seguir.

\section{Esporte como direito social (?)}

O direito ao esporte, inscrito na Constituição Federal de 1988 como direito de cada um, deixa subtendido que ele se constitui uma obrigação negativa do Estado por aproximar-se dos direitos civis, ou direitos individuais. Simões (2013) avalia que neste caso, o Estado deve propiciar e promover a sua oferta, mas caberia a cada indivíduo a decisão de usufruí-lo ou não. O marco legal do direito ao esporte e suas legislações infraconstitucionais têm possibilitado interpretações contraditórias a respeito de sua intencionalidade e ações governamentais obrigatórias. Especialmente por atribuir e ele uma interpretação triádica (que discutiremos adiante), esse arcabouço jurídico permite ao esporte trânsito entre os direitos sociais constitucionalmente instituídos à educação e ao lazer.

Por isso, nas políticas públicas que decorrem do direito ao esporte, ainda que este esteja inscrito constitucionalmente como direito individual, abrem-se prerrogativas para serem disputados e/ou concebidos na lógica dos direitos sociais, pois a Constituição Federal (CF) estipula em seu Art. 6:

Art. $6^{\circ}$ São direitos sociais a educação, a saúde, a alimentação, o trabalho, a moradia, o lazer, a segurança, a previdência social, a proteção à maternidade e à infância, a assistência aos desamparados, na forma desta Constituição. (Redação dada pela Emenda Constitucional n 64 , de 2010) ${ }^{16}$

Sobre o Lazer, recorremos ao alerta feito por Mascarenhas (2005; 2008) para as contradições presentes no capitalismo contemporâneo que dificultam a efetiva consolidação deste como um direito social. Ele aponta as questões da relação dos direitos sociais com o Estado, que sinaliza para a desconstituição desses direitos

16 Disponível em: http://www.planalto.gov.br/ccivil 03/constituicao/constituicao.htm. Acesso: $21 / 11 / 2014$ 
engendrada pela Contra-Reforma do Estado. Com este movimento, o lazer e o esporte, segundo o autor, deixaram de ser instrumentos de acesso a cidadania para tornarem-se produtos de consumo (MASCARENHAS, 2008). Somados a isso, a precarização dos trabalhadores da área, a terceirização dos serviços de lazer e a falta de controle social revelam que o direito ao lazer (e ao esporte) se apresenta apenas no discurso, não se efetivando na prática. E anuncia:

\begin{abstract}
Opera-se, de tal modo, uma verdadeira metamorfose no entendimento da noção de direito, com o direito de propriedade contraditando com os direitos sociais, com o direito do consumidor sobrepondo-se aos chamados direitos de cidadania. Isto significa dizer que o princípio meritocrático que está na base da lógica distributiva em vigor é o do não-direito, pois "consumir, trocar, vender são ações que, ainda que amparadas em certos direitos, identificam ou apelam aos indivíduos em sua exclusiva condição de consumidores" (GENTILI, 1995, p. 240). Nesta perspectiva, o lazer torna-se acessível apenas para uma minoria, apresentando-se como um tipo muito específico de propriedade. Somente de posse deste "direito", adquirido numa relação de compra e venda, efetuada no mercado nem sempre de modo direto, que o cidadão-consumidor, como proprietário, pode valer-se do direito ao consumo, usufruindo, desfrutando, fruindo ou gozando de um determinado complexo de experiências lúdicas proporcionadas por aquilo que doravante convencionaremos chamar por mercolazer, forma contemporânea e tendencial de manifestação do lazer como mercadoria.- (MASCARENHAS, 2005, p. 105/106)
\end{abstract}

Desde o ano de 2003, a partir da criação do Ministério do Esporte, o Estado efetivamente iniciou a discussão para que este direito constitucional dos cidadãos e cidadãs brasileiras fosse garantido a partir de ações e políticas governamentais. Segundo Figueiredo (2009), sua criação respondia a uma demanda social para garantia dos dispostos constitucionais em relação ao esporte e ao lazer. Criado através da Medida Provisória No 103/2003, convertida posteriormente na Lei $N^{\circ}$ 10.683 de 28/05/2003 (FILGUEIRA; FERES NETO, 2012), a criação do ME inaugurou um terreno onde se encontraram diferentes abordagens ideológicas, filosóficas e políticas acerca do direito de acesso ao esporte e lazer.

Segundo Figueiredo (2009), esse terreno era frequentado por atores que representavam blocos distintos; um deles, considerado pelo autor como hegemônico do esporte, é constituído pelo Comitê Olímpico Brasileiro (COB) e o Sistema CREF/CONFEF e o outro, de instituições representativas de pesquisadores, professores e demais membros da sociedade civil com acúmulo para pensar e redimensionar as políticas públicas de esporte e lazer para sua efetivação no âmbito 
das políticas sociais. Por sua vez, Castelan (2011) identifica que o comando do Ministério foi entregue ao Partido Comunista do Brasil (PCdoB), partido que não possuía acúmulo expressivo na área do esporte e lazer ao contrário do Partido dos Trabalhadores (PT) - partido do então presidente e líder da coalisão governamental que já possuía um Setorial de Esporte e Lazer organizado desde 1998, além de formulações sistematizadas sobre o tema.

Nessa composição de forças, segundo a autora, o PT acabou tendo que se contentar com apenas uma secretaria dentre as três criadas no interior do Ministério ${ }^{17}$. $E$, para que o grupo político dominante $(\mathrm{PCdoB})$ pudesse garantir legitimidade perante o outro grupo - que possuía em suas fileiras membros com acúmulo na comunidade acadêmica progressista vinculada à Educação Física e ao esporte - foram buscar apoio e respaldo em entidades como a Confederação Brasileira de Futebol (CBF) e o COB (CASTELAN, 2011). Atores que Figueiredo (2009) apontou como hegemônicos no esporte nacional e, como podemos contatar contemporaneamente, nunca saíram de cena apesar de representarem no âmbito da política esportiva nacional apenas os seus próprios interesses.

Diante dessa guerra de posições no ME, tomando emprestada uma expressão de Gramsci sobre o direcionamento e peso das políticas, a criação de políticas efetivas recolocou o debate sobre o esporte como direito de cidadania, dando o pontapé inicial para o desenvolvimento de políticas públicas voltadas a este fim. Ações como a criação de programas sociais, instauração de uma Política Nacional de Esporte e a criação das Conferências Nacionais de Esporte representaram um salto que, inicialmente, poderia constituir-se na guinada fundamental para o reconhecimento do papel do esporte como elemento de direito à cidadania. Para este fim, o ME desenvolveu políticas chamadas Políticas Sociais de Esporte visando que este direito fosse efetivamente garantido ao conjunto de cidadão brasileiros.

Mas, diante dos limites e circunstâncias impostos pela trajetória política de nossas legislações sociais frente ao estágio do capitalismo contemporâneo de viés

\footnotetext{
${ }^{17}$ As Secretarias criadas na ocasião da fundação do ME foram: Secretaria Nacional de Alto Rendimento (SNEAR), Secretaria Nacional de Esporte Educacional (SNEE), sob a direção do PCdoB, e Secretaria Nacional de Desenvolvimento do Esporte e Lazer (SNDEL), esta última a única sob o comando do PT com a ajuda de seu Setorial de Esporte e acadêmicos da área (CASTELAN, 2011). A SNEAR se incumbiu inicialmente de cuidar das políticas para o Pan-Rio 2007, a SNEE do Programa Segundo Tempo e a SNDEL do Programa esporte e Lazer na Cidade (id.). Tais Programas e suas ações diretivas são abordadas mais à frente, e nos possibilitarão avaliar se o direito ao esporte estaria sendo garantido através dessas políticas.
} 
neoliberal, surgiu a reflexão se essas políticas conseguiriam consolidar-se como políticas universais que atendessem às necessidades básicas e a garantia de direitos de cidadania, na medida em que o direito ao esporte fora postulado como um direito social. Pereira e Stein (2010) afirmam que as políticas sociais devem sempre obedecer ao princípio da universalidade e equidade para que de fato sejam compreendidas como tal. Esse raciocínio é importante para situar o percurso do esporte no rol das políticas sociais, especialmente após o primeiro governo Lula. Buscaremos aproximação a esses conceitos a seguir.

\section{a-) Universalização, focalização e o direito ao esporte}

Pereira e Stein (2010) dizem que o princípio da universalidade, o qual acreditam apresentar uma conotação pública, cidadã, igualitária ou equânime na implantação de políticas, vem perdendo terreno ultimamente para um discurso focalista e neoliberal de extração pós-moderna o qual postula que "o ser humano é construído culturalmente e, assim, despossuído de vínculos universais e de convergências éticas, políticas e cívicas" (PEREIRA; STEIN, 2010, p. 107). As autoras afirmam que as políticas sociais universais tiveram origem nas políticas keynesianistas, com a contribuição do Plano Beveridge ${ }^{18}$, que assumiu o compromisso com o pleno emprego e a criação de serviços sociais de caráter universal (para todos), preconizando uma rede de segurança que garantisse padrões de vida acima da linha de pobreza. Essas políticas procuravam viabilizar os direitos sociais, gerando condições para o exercício dos direitos individuais (civis e políticos) e garantiam aos cidadãos acesso aos meios de trabalho e participação política (PEREIRA; STEIN, 2010).

As autoras ressaltam que foi a partir da década de 1970, com a mudança no processo de intervenção pública provocada pela crise do capitalismo mundial que o "Estado Social" foi se esvaziado. E na medida em que as teses neoliberais se fortaleciam, reformas políticas que corroborassem essa lógica passaram a ser

\footnotetext{
${ }^{18}$ Segundo Pereira e Stein (2010), Willian Beveridge foi um político inglês que organizou um sistema unificado de seguridade social na Grã-Bretanha em plena Segunda Guerra Mundial, implantando o sistema de seguridade social que contemplava os seguros de natureza contributiva e a assistência social de natureza distributiva. Tal modelo, segundo as autoras, servira de referência para diversos países, entre eles o Brasil.
} 
previstas sob a intervenção do Estado, tais como enfraquecimento nos sistemas de proteção social, privatizações, fragmentação e focalização de políticas sociais:

\begin{abstract}
No centro dessa orientação estava implícito o desmonte dos direitos sociais, ressuscitando antigos procedimentos de ajuda mútua, baseados numa controvertida solidariedade guiada por uma nova "divisão social do bemestar" em que o Estado perderia o protagonismo. (PEREIRA; STEIN, 2010, p. 110).
\end{abstract}

Foi a partir desta década que a "seletividade" passou a prevalecer sobre a universalidade, pois ganhava força a concepção de política social como receita técnica governamental e estratégia de compensação de "dívidas sociais", especialmente no que se referia à pobreza. Esse movimento se contrapõe ao que as autoras preconizam como o princípio da universalidade, o qual tem vínculo direto com o princípio democrático de pleno acesso aos bens e serviços públicos e através deste princípio são indivisíveis e deveriam estar ao acesso de todos, sem qualquer distinção ou discriminação.

\begin{abstract}
Não discriminar, por esta perspectiva, significa não estabelecer critérios desiguais de elegibilidade que humilhem, envergonhem, estigmatizem e corrompam o status de cidadania de quem precisa de proteção social pública. Significa também não encarar a política pública [...] como fardo governamental ou desperdício a ser cortado a todo custo. Além disso, outra razão histórica importante para a adoção do princípio da universalidade decorreu da descoberta feita por várias forças sociais em pugna pela democracia da ideia de prevenção nele contida. (PEREIRA; STEIN, 2010, p. 111. Grifos originais)
\end{abstract}

O conceito de prevenção contida nos direitos sociais associado ao princípio da universalidade significa para as autoras o antídoto a todo constrangimento impingidos aos pobres no processo de satisfação de suas necessidades básicas e na luta por melhores condições de vida e de cidadania. Entretanto, a complexidade da aplicação desses valores na sociedade de classes e a utilização da política social como receitas técnicas e medidas de compensação social foram permitindo a sobrepujança da seletividade sobre a universalidade.

Pereira e Stein (2010) argumentam que as políticas seletivas ou focalistas não são capazes de fomentar a inclusão social, pelo contrário, reforçam a exclusão e a pobreza, pois tem como objetivo principal excluir e manter excluídos o máximo possível de demandantes da proteção do Estado. Isso acaba por fortalecer uma 
cultura política do assistencialismo e dependência, já que tais assistidos (ou faltosos, segundo as autoras) transformam os seus direitos básicos (educação, saúde, terra, entre outros) em contrapartidas ditadas e cobradas pelos agentes responsáveis pela sua "inadimplência involuntária" (PEREIRA; STEIN, 2010, p. 116). Para as autoras, no princípio da focalização as necessidades humanas daqueles que usufruem destas políticas são rebaixadas ao nível da sobrevivência ou "sua mísera expressão animal" (p. 115), representando uma concepção equivocada de política social e configurandose um paliativo (e não uma mediação) para ampliação da cidadania.

As autoras acreditam que, dentre os inúmeros fracassos e irracionalidades contidos nas políticas sociais focalizadas, sua principal característica seria a incapacidade de solucionar o problema da iniquidade e da luta por direitos na sociedade de classes. Nesse sentido, a política social cumpriria um papel estratégico em contribuir para a universalização do conjunto das políticas públicas em virtude da sua interdisciplinaridade e intersetorialidade, ou seja, sua capacidade de estabelecer interfaces entre diversas políticas (econômicas, sociais, trabalho, educação, etc.) em diversas esferas (Estado estrito ou sociedade civil).

Resgatar a construção dos direitos sociais através da política pública nos auxilia a compreender as políticas de esporte em sua perspectiva de direito social pensando em suas expressões constitucionais do lazer e da educação. A construção do direito ao esporte sempre esteve recheada de interesses que coadunaram com a perspectiva da liberalização, ainda que constitucionalmente se vislumbre como prioridade a sua perspectiva (ou manifestação, segundo TUBINO, 2010) educacional. Para mascarar ou fantasiar propósitos que, em verdade, caminham em sentido contrário à universalização e consecução de direitos de cidadania, o esporte, fenômeno social de grande respaldo, fora revestido no decorrer de sua trajetória histórica enquanto política, de uma aura mistificada que lhe garantisse legitimidade e ampla inserção através de nobres valores morais e sociais.

Essa mistificação é compreendida por Flausino e Mascarenhas (2012) como adjetivações que conferem ao esporte o status de solução de problemas sociais como a drogadição juvenil, a violência, saúde e exclusão social. Ou seja, mistificação é algo que sugere uma fantasia, ilusão ou falsidade. Tal discurso mistificador, que é reproduzido tanto pelo próprio Estado através do $\mathrm{ME}$ e das Resoluções da Conferência Nacional de Esporte (CNE) como também pela mídia, possui o que 
chamam efeito perlocucional, pois nesta fala o emissor não declara ou admite seus objetivos implícitos, usados, portanto, para produzir ilusão ou alienação (FLAUSINO; MASCARENHAS, 2012). E, segundo os autores, não é possível pensar em uma efetiva democratização de qualquer política social sem que a mesma não garanta a universalidade, o caminho contrário utilizado nas políticas esportivas, que é o da focalização.

Da mesma forma, tais adjetivações e o efeito perlocucional decorrente delas podem auxiliar a criar uma falsa sensação de coesão social ao redor do esporte, muito presentes no senso-comum através deste discurso mistificador (MASCARENHAS, 2008). Esse discurso, que acaba tornando súmula vinculante ao esporte conceitos de cidadania, qualidade de vida e saúde tornam-se "abstrações mistificadoras", que se não forem qualificadas e criticizadas legitimam as políticas esportivas e sociais em curso sem que se qualifiquem esses conceitos e as concepções teórico/políticas que o embasam.

Já Liáo Jr. (2013) acredita que Programas e Ações direcionados a inclusão do esporte como direito social, para que configurem efetivamente como uma política social em seu espectro de garantia de direitos de cidadania, devem afastar-se da pauperização que essas políticas vêm sofrendo diante a hegemonização de interesses antagônicos a universalização e democratização. Ele assevera que as alianças estabelecidas entre o Estado e os setores conservadores ligados ao esporte de rendimento, ou seja, no aspecto de negócio, têm preponderado na pauta política do ME, em contradição ao que vislumbra os objetivos, princípios e diretrizes da Política Nacional de Esporte desenvolvida em 2005, que propunha

\begin{abstract}
democratizar e universalizar o acesso ao esporte e ao lazer na perspectiva da melhoria da qualidade de vida da população brasileira; promover a construção e o fortalecimento da cidadania, assegurando o acesso às práticas esportivas e ao conhecimento científico-tecnológico a elas inerente; descentralizar a gestão das políticas públicas de esporte e de lazer; fomentar a prática do esporte de caráter educativo e participativo, para toda a população, além de fortalecer a identidade cultural esportiva a partir de políticas e ações integradas com outros segmentos; incentivar o desenvolvimento de talentos esportivos em potencial e aprimorar o desempenho de atletas e paraatletas de rendimento, promovendo a democratização dessa manifestação esportiva. (LIÁO JR, 2013, p. 85) ${ }^{19}$
\end{abstract}

${ }^{19} \mathrm{O}$ autor assevera que a garantia dos direitos à prática e à fruição do esporte e do lazer, deve se materializar através da perspectiva emancipatória e não de "abstrações mistificadoras" (id.), tais como "inclusão social", "ferramenta para a paz", "educação para a cidadania", "qualidade de vida", 
Tais medidas, previstas na Política Nacional de Esportes, não somente foram proteladas pelas ações e condutas do Estado (através do poder executivo - o ME) que privilegiou as alianças com os setores econômicos vinculados à pasta, também foram secundarizadas frente aos "descaminhos" enfrentados pelas Conferências Nacionais de Esporte, as quais ao contrário de se instituírem um espaço de democratização das questões oriundas do esporte tornaram-se uma ferramenta para chancelar e ratificar as novas alianças e prioridades do Estado frente aos Megaeventos esportivos (LIÁO JR., 2013).

Tudo isso se contrapõe à efetiva consolidação do esporte enquanto elemento satisfador de direito de cidadania, afastando-o da perspectiva dos direitos sociais universais preconizados por Pereira e Stein (2010). O esporte no âmbito das políticas de Estado guarda maior proximidade, talvez com a assertiva marxiana: "O executivo do Estado moderno não é mais do que um comitê para administrar os negócios coletivos de toda a classe burguesa" (MARX; ENGELS, 1998 apud PAULO NETTO, 2012, p. 187) ${ }^{20}$. Para tentar elucidar melhor esse pressuposto, recorremos a compreensão que a lógica da manifestação hegemônica do esporte, a do esporte de rendimento, ressoa também na lógica do mercado de consumo por meio do modelo da pirâmide esportiva ${ }^{21}$, que por sua vez se entrelaça ao arcabouço legal e nas políticas de esporte fomentadas pelo Estado. Até mesmo nas políticas sociais que envolvem o esporte, chamadas de políticas sociais esportivas oriundas especialmente após a criação do Ministério do Esporte em 2003, prevalece a lógica da focalização,

\footnotetext{
"desenvolvimento humano" (ibid.). Ele afirma que a agenda imposta pelo controverso "Legado Social", trazido pelos Megaeventos como articulador de uma política nacional de esporte Programas e Ações, distanciam as políticas esportivas como um instrumento das Políticas Públicas consequentes aos Direitos Sociais, aproximando-as a uma "permanente projetização e pauperização destas políticas sociais". (LIÁO JR., 2013, p. 86)

${ }^{20}$ Certamente essas elaborações respondiam a demanda pela emancipação humana diante do cenário sociopolítico de sua época. Naquela circunstância, Marx compreendia o Estado como ente que garantia a estrutura da sociedade de classes (SADER, 2014), e que de acordo com sua compreensão, manteriam via unicidade de classe (ou seja, ausência de frações e conflitos internos) a manipulação da supraestrutura política, subjugando à sua vontade os mecanismos de controle, regulação e fomento de seus interesses (ibid.). Portanto, nada mais coerente em tomá-lo como um balcão para seus negócios! Todavia, Gramsci ao contemporizar nas primeiras décadas do século XX a teoria de Marx sobre o Estado frente as mudanças verificadas na dinâmica das relações sociais e de trabalho com a conquistas de direitos civis, políticos e sociais que Marx não teve a chance de vivenciar, enxergou a possibilidade se disputar interesses de cada classe no interior do próprio Estado, pois segundo sua compreensão, as classes trabalhadoras também seriam integrantes do Estado, agora compreendido em sentido ampliado: Estado = sociedade política + sociedade civil, conceito ao qual nos filiamos por acreditar que esta forma de organização é mais condizente com a dinâmica de organização social de nossos dias. 21 Sobre o modelo da pirâmide esportiva, forma de intervenção na Educação Física escolar que a concebe como espaço de formação da base do sistema esportivo de alto rendimento, linhas com contornos mais específicos estarão disponíveis adiante.
} 
acobertada pela mistificação deste fenômeno social (MASCARENHAS, 2008; FLAUSINO; MASCARENHAS, 2012). Nesse movimento, buscaremos aproximação às duas políticas sociais esportivas mais relevantes, o PST e o PELC, as quais, de acordo com o ME, intencionam resgatar o esporte como direito social.

\section{b-) Políticas sociais esportivas}

Segundo Boschetti (2009), guardando-se o princípio da totalidade é possível situar o desenvolvimento das políticas sociais com o das políticas econômicas. Como as políticas sociais devem ser entendidas como um conjunto de programas, projetos e ações que devem universalizar direitos, é preciso compreendê-la como parte de um todo complexo que influencia e é influenciado por toda a malha dos fenômenos sociais, neste caso, aqueles que repercutem na concepção, elaboração e implantação das políticas públicas. Do ponto de vista de sua relação com as políticas econômicas, a autora acredita que é importante relacionar a política social com as questões estruturais da economia e seus efeitos para as condições de produção e reprodução da vida da classe trabalhadora, ou seja,

[...] buscar relacionar as políticas sociais com as determinações econômicas que, em cada momento histórico, atribuem um caráter específico ou uma dada configuração às políticas sociais, assumindo, assim, um caráter histórico-estrutural (BOSCHETTI, 2009, p. 8).

Vieira (2009) complementa essa compreensão afirmando que a política econômica e a política social caminham juntas e unidas no desenvolvimento do capitalismo, pois vinculam-se à evolução do capital, entendido por ele como concentração e transferência de riqueza de uma classe para outra. Ele ressalta que há complementaridade entre as políticas social e econômica, pois a primeira expressa relações sociais cujas raízes encontram-se no mundo da produção.

E a partir da entrada do esporte na pauta de discussão das políticas públicas sociais através da criação do Ministério do Esporte (ME) e de suas políticas sociais esportivas, buscamos em Athayde (2011) a compreensão de que o esporte, ao entrar nesta agenda, navegou conjuntamente às políticas sociais e econômicas 
desenvolvidas pelos governos do presidente Lula (2003 a 2010). Essas políticas foram o carro chefe das mudanças políticas e sociais que acabaram por colocar em pauta a compreensão do esporte como direito, portanto, alvo de políticas públicas.

O princípio básico das políticas estruturais (especialmente a econômica) que modernizaram as políticas sociais deste mandato, segundo Athayde (2011), combinava a inclusão de classes anteriormente desassistidas pelas políticas de proteção social no mercado de consumo, assim como sua inclusão nessas políticas. Contudo, não houve rompimento com o modelo liberal e ortodoxo adotado pelos governos anteriores, especialmente os 8 anos que o antecederam (governo Fernando Henrique Cardoso). De tal forma, as políticas sociais davam um salto no sentido de incluir socialmente um maior quantitativo de pessoa sem que houvesse necessariamente uma hipertrofia nas políticas universalistas ou ainda, o rompimento da ortodoxia econômica (ATHAYDE, 2011). Um exemplo, segundo o autor é o Programa Bolsa Família, carro chefe das políticas sociais deste governo.

\begin{abstract}
Em síntese, podemos perceber que o argumento de criação das condições necessárias para a implementação de novas políticas econômicas e sociais caracterizou-se como "um discurso apaziguador conjuntural, que serviu de justificativa, durante os meses iniciais do governo, para a manutenção do mesmo modelo econômico" (FILGUEIRAS; PINTO, 2004). Com o passar do tempo, esse sofisma foi abandonado e trocado pela alocução de que existe uma única política macroeconômica no contexto atual, sendo possíveis apenas modificações epidérmicas nessa estrutura preconcebida. (ATHAYDE, 2011, p. 191)
\end{abstract}

Nesse contexto, as ditas políticas sociais de esporte do governo Lula, representadas especialmente por dois programas - o Programa Segundo Tempo (PST) e o Programa Esporte e Lazer na Cidade (PELC), com ênfase maior neste primeiro - sinalizaram a inclusão do direito ao esporte na pauta das políticas públicas $^{22}$. Isso foi, segundo o autor, mais verdadeiro no primeiro mandato, pois no

22 O PST, carro chefe das políticas sociais esportivas nos dois mandatos do governo Lula (e do governo Dilma também) era anunciado como uma revolução ao reconhecer, enfim, o esporte como direito social. Nas palavras de Athayde (2011, p.197) "parecia expressar uma autêntica mudança na relação entre Estado e Esporte, materializada pelo entendimento - por parte do ME - de que o esporte passaria a ser tratado como direito de cada cidadão e que, portanto, deveria ser objeto de uma política social". Animava também a potencial abrangência do Programa - indivíduos em idade escolar.

Em nosso entendimento essa política representou a astuta inserção do esporte de rendimento nos ambientes escolares travestida de um sentimento de mudança e esperança que pairavam na atmosfera política do país (SINGER, 2012). Essa atmosfera nebulosa era alimentada, no caso do esporte como política pública, pelo discurso mistificador/salvacionista atribuído a este. Nas mãos de pessoas e grupos habilidosos (como aqueles que construíram o direito e o marco legal do esporte) essa política poderia se tornar o pano de fundo da legitimação de interesses antidemocráticos como aqueles representados 
segundo houve uma guinada explícita na priorização de outras pautas respectivas ao esporte: os Megaeventos Esportivos (Jogos Mundiais Militares Rio 2011, Copa do Mundo FIFA 2014 e Olimpíadas Rio 2016). O autor demonstra uma enorme disparidade de investimentos em recursos destinados e gastos com Programas envolvidos na realização desses dois eventos em detrimento dos realizados com o $\mathrm{PST}^{23}$. Asseverando que os investimentos em pautas que privilegiam o esporte de alto rendimento não garantem a ampliação de direitos ${ }^{24}$, Athayde (2011) conclui que esta política se afasta de uma efetiva democratização do esporte:

[...] os direcionamentos dados às políticas econômicas e sociais pelo projeto de desenvolvimento trataram de afastar o esporte de seu conteúdo social, priorizando sua manifestação hegemônica e as ações que estivessem vinculadas à política macroeconômica. Dessa forma, observamos, por meio do financiamento público, uma acentuada priorização de alocação de recursos na promoção do esporte de alto rendimento ou espetáculo e na realização dos Megaeventos Esportivos em detrimento de maiores investimentos nos programas e projetos sociais, mitigados os aspectos sociais do esporte, os quais, quando lembrados, são rapidamente subordinados aos interesses hegemônicos. (ATHAYDE, 2011, p.207)

Ainda sobre as políticas sociais do período, Matias (2014) estabelece um contraponto à essa lógica desenvolvida pelo PST, destacando o Programa Esporte e Lazer na Cidade (PELC), também do ME, como uma possibilidade de política que realmente atenderia aos anseios de democratização e ampliação de direitos pautados nos direitos de cidadania. O autor diz que em termos gerais, os princípios do PELC são os mesmos presentes no documento Política Nacional de Esporte, publicado em 2005, quais sejam: a) Reversão do quadro atual de injustiça, exclusão e violência social; b) Esporte e lazer como direito de cada um e dever do Estado; c) Universalização e inclusão social; d) Democratização da gestão e da participação (BRASIL, 2005 apud MATIAS, 2014).

pelos Megaeventos: a legitimação pelo alto, e através de um instrumento democrático - a política pública - da lógica da pirâmide esportiva.

${ }^{23}$ Foram transferidos $\mathrm{R} \$ 36,089$ bilhões pela União para a realização dos Megaeventos entre 2004 e 2010, enquanto no mesmo período foi transferido ao PST R $\$ 672,52$ milhões (ATHAYDE, 2011), uma diferença de $R \$ 35,41$ bilhões a favor do esporte de alto rendimento.

${ }^{24}$ Assim como as políticas focalistas também não garantem, conforme vimos em Pereira e Stein (2010). A principal política social de esporte engendrada pelo Estado (o PST) assume contornos de política focalista, pois é voltada para jovens em idade escolar, preferencialmente em situação de vulnerabilidade social. Fonte: http://esporte.gov.br/index.php/institucional/esporte-educacao-lazer-einclusao-social/segundo-tempo. Acesso: 25/02/2015 
Ele traz dados expressivos de atendimento realizados pelo PELC até o ano de 2010 (10.602.559 de atendimentos a cidadãos de 1.277 municípios com atividades de esporte recreativo e de lazer). Entretanto, afirma que

\begin{abstract}
Apesar dos dados serem expressivos para a realidade do setor esportivo brasileiro, o ME está bem distante de implementar uma política universal de esporte e lazer. O Pelc, que representa um marco conceitual referenciado em princípios emancipatórios, sofreu ao longo dos anos com a contenção de recursos e a subordinação da agenda do ME inicialmente ao Programa Segundo Tempo (PST) e ao esporte de alto rendimento (EAR). (MATIAS, 2014, p. 148/149)
\end{abstract}

Outro obstáculo apontado pelo autor ao desenvolvimento do Programa é a precariedade e a má distribuição da infraestrutura esportiva e de lazer existente nos municípios atendidos, associado a cultura política da distribuição de emendas parlamentares por determinadas regiões que constituem nichos políticos individuais. Matias (2014) afirma que muitas delas são "direcionados para regiões do deputado que a propôs e servem especialmente à prática do esporte de Alto Rendimento (EAR)" (MATIAS, 2014, p. 149). E sobre a questão dos gastos respectivos aos recursos repassados pela União ao ME entre 2008 e 2010, o PELC é beneficiado com 11,6\% do montante total, enquanto o PST se beneficia de $23,3 \%$ e o EAR, 55,1\% (MATIAS, 2014).

Para compreender esse esvaziamento do PELC o autor resgata que o governo Lula, em especial em seu primeiro mandato, não consegue estabelecer uma ruptura com os ditames da cartilha neoliberal de diminuição do papel do Estado e cortes nos direitos sociais a partir das políticas econômicas. Mesmo que em seu segundo mandato se consiga aliar o desenvolvimento econômico ao desenvolvimento social, especialmente através da ampliação da proteção social, estabilidade, distribuição de renda, o autor afirma que as intervenções sociais do governo são de caráter seletivas e focalistas, com muitos programas de caráter assistencialistas e voltados para a conservação e atendimento a interesses políticos de frações das classes que compõem o bloco no poder.

Essa acomodação do governo Lula aos ditames neoliberais somado ao oportuno sucesso do PST e a influência arrebatadora dos Megaeventos na agenda governamental representam limites que dificultaram a consolidação do PELC como uma política social universalista e democrática, voltada para a efetiva consolidação do 
direito constitucional ao esporte a partir da entrada do esporte na pauta das políticas públicas com a criação do ME. Matias (2014) avalia que o PELC é o Programa que mais se aproxima da intenção originária por ocasião da criação do ME:

\begin{abstract}
O programa, que melhor representa esta nova compreensão governamental, sem dúvida, é o Pelc. Com um desenho conceitual inovador, ele possui suas diretrizes e pressupostos (auto-organização, trabalho coletivo, intergeração etc.) que rompem com as políticas tradicionalmente desenvolvidas no setor. Inspirado em experiências acadêmicas e de administrações do campo popular e democrático, se estrutura em três eixos: a) funcionamento de núcleos de esporte recreativo e de lazer; b) desenvolvimento de infraestrutura; c) rede de centros de desenvolvimento de pesquisa. (MATIAS, 2014, p. 156/157)
\end{abstract}

O Programa Esporte e Lazer na Cidade talvez tenha sido a política pública de esporte que mais se aproximara da perspectiva de democratização para a cidadania. Entretanto, diante de tantos elementos que demonstram o distanciamento da lógica da universalização, de interesses privados e mercantis que saltam às vistas frente às políticas públicas de esporte, compreendemos que, em consonância ao percurso histórico do esporte, é muito difícil apanhar este produto da humanidade como um direito social no Brasil, pelo contrário, as políticas públicas atuais têm corroborado o movimento liberal, privatista e usurpador de fundo público conforme temos observado. Isso se contrapõe ao discurso oficial de ampliação da cidadania democratização do esporte. Dessa forma percebemos que na disputa por hegemonia no interior do Estado, conforme pondera Gramsci (apud COUTINHO, 2011), os interesses das frações de classe que defendem a visão liberal/privatista estão à frente daqueles que defendem a efetiva democratização do esporte.

Castellani Filho (2007) entende que o esporte e o lazer devem ser compreendidos como direito social por serem identificados como um patrimônio cultural da humanidade, e como tal, devem ser por direito apreendidos. Entretanto, pela dinâmica empenhada na garantia deste direito constitucional, tomando como referência a concepção de Pereira e Stein (2010) de como se configura um direito social (a partir de sua universalidade e equidade), se torna difícil compreender a concretização deste patrimônio cultural como um direito social brasileiro.

Ele atualmente inscreve-se, pelo que percebemos, no rol das políticas focalistas, as quais são uma estratégia de manutenção da ordem social e monetarização das políticas (MATIAS, 2013), essas, instrumentos compatíveis e 
coerentes com a dinâmica de prioridades e investimentos do Estado em relação aos Megaeventos esportivos.

Verifiquemos se isso também é verdadeiro para as políticas específicas de esporte educacional, esta uma possibilidade de intersecção entre políticas esportivas (que se inclinam à lógica liberal) e políticas educacionais (que a priori deveriam tanger às políticas sociais).

\section{As políticas de esporte educacional no Brasil}

Tomando como referência o período proposto para nossa análise (2008-2015), percebemos que a priori as políticas de esporte desenvolvidas no Brasil abordam prioritariamente o esporte entendido como educacional obedecendo a perspectiva da pirâmide esportiva, ênfase especialmente revelada por Seron (2013) no Decreto No 7.984/2013, o ordenamento legal mais atual sobre o esporte no Brasil.

Essa análise pode ser corroborada por Mascarenhas (2008), quando este afirma que a flexibilidade do conceito esporte educacional permite que no financiamento do esporte, importante indicador para avaliar as políticas públicas, se desloquem do âmbito da garantia do direito social para o investimento no mercado. Dessa forma, segundo o autor, fica garantido fortes repasses ao esporte de rendimento/esporte espetáculo, justificado pela argumentação de que o esporte de rendimento e o esporte espetáculo garantiriam também, a prática educativa:

\footnotetext{
Então uma imprecisão conceitual ou um conjunto de significados e sentidos que podem ser dados a uma dada categoria, tem implicações no campo do financiamento, que por sua vez tem desdobramento na garantia efetiva e concreta do direito social ao esporte. (MASCARENHAS, 2008, p.99)
}

Tal assertiva nos é demonstrada pelo desenho dos principais Programas ou ações desenvolvidas pelo governo federal que tangem especificamente ao esporte educacional, demonstrados no Quadro 1, a seguir. 
Quadro 1 - Políticas de esporte educacional do governo federal

\begin{tabular}{|c|c|c|c|}
\hline POLÍTICA / AÇÃO & PERÍODO & $\begin{array}{c}\text { ATORES } \\
\text { RESPONSÁVEIS }\end{array}$ & $\begin{array}{c}\text { MODELO DE } \\
\text { GESTÃO }\end{array}$ \\
\hline $\begin{array}{c}\text { Programa } \\
\text { Segundo Tempo }\end{array}$ & 2003 - atual & $\begin{array}{c}\text { ME; Entes Federativos } \\
\text { (Prefeituras, governos } \\
\text { estaduais e governo } \\
\text { federal) }\end{array}$ & Convênios \\
\hline Atleta na Escola & 2013-atual & $\begin{array}{c}\text { MEC; FNDE; Entes } \\
\text { Federativos; Unidades } \\
\text { Escolares (públicas e } \\
\text { particulares); COB; } \\
\text { CPB; Confederações } \\
\text { (atletismo, judô, } \\
\text { futebol) }\end{array}$ & Convênios \\
\hline $\begin{array}{l}\text { PST - Mais } \\
\text { Educação }\end{array}$ & 2010-atual & $\begin{array}{c}\text { ME; MEC; Unidades } \\
\text { Escolares }\end{array}$ & Convênios \\
\hline $\begin{array}{c}\text { Olimpíadas } \\
\text { Escolares (2008- } \\
\text { 2012) / Jogos } \\
\text { Escolares da } \\
\text { Juventude (2009 } \\
\text { - atual) }\end{array}$ & 1969 - atual $\left.\right|^{27}$ & $\mathrm{ME} ; \mathrm{COB}$ & Privada \\
\hline
\end{tabular}

É importante destacar que um item não integrante desse quadro e que diz respeito a uma importante fonte de financiamento de ações ligadas ao esporte educacional corresponde a Lei Agnelo-Piva ( $N^{\circ} 10.264$ de 16/07/2001), a qual estabelece critérios de financiamento para o esporte nacional a partir do fundo estatal. Ela destina $2 \%$ da arrecadação bruta de concursos prognósticos e loterias federais

\footnotetext{
25 Até outubro de 2011 os convênios do PST poderiam ser celebrados entre o ME e outros entes públicos, assim como também entidades de direito privado. Isso mudou com o escândalo das ONGs na gestão do Ministro Orlando Silva no mesmo ano, quando tais convênios foram suspensos por decreto presidencial da presidenta Dilma Rousseff.

${ }^{26}$ Fonte: http://atletanaescola.mec.gov.br/programa.html. Acesso em 09/03/2015

${ }^{27}$ Nasceu como Jogos Estudantis Brasileiros, transformou-se no decorrer de sua história em Jogos Escolares Brasileiros, Campeonatos Escolares Brasileiros, Jogos da Juventude, Olimpíadas Colegial Esperança, Olimpíadas Escolares e os atuais Jogos Escolares da Juventude. Fonte: http://www.esporte.gov.br/index.php/institucional/alto-rendimento/jogos-escolares-brasileiros/historico. Acesso: 09/03/2015
} 
para o desporto nacional na proporção de $85 \%$ do montante arrecadado destinado ao COB e 15\% ao Comitê Paraolímpico Brasileiro (CPB). E desse montante destinado ao $\mathrm{COB}$, a Lei prevê para investimento no esporte educacional apenas $15 \%$, dos quais $10 \%$ se destinam ao esporte escolar e 5\% ao esporte universitário (recursos administrados pelo próprio $\mathrm{COB}$ ).

Ou seja, há uma inclinação institucional para se ignorar o Item II do Art. 217 da Constituição Federal: II - a destinação de recursos públicos para a promoção prioritária do desporto educacional e, em casos específicos, para o desporto de alto rendimento. Isso implica dizer que um dos principais fundos de financiamento público para o esporte educacional é direcionado à administração de uma entidade que promove e administra o desporto de alto rendimento, que de forma astuta repassa ao esporte educacional seus recursos de forma a ratificar o esporte de alto rendimento, reinvestindo essa verba de acordo com sua compreensão e expectativas de esporte educacional, como por exemplo, a organização das Olimpíadas Escolares.

Retomando ao quadro, nossa análise inicial das políticas nacionais de esporte educacional não pretende hierarquizá-las qualitativamente frente aos demais programas/ações em vigor nos estados, mas sim tomá-lo como exemplo em virtude do entendimento deste pesquisador de que a União representa o ente federativo com maior força política e institucional para gerir e promover políticas públicas, assim como ser o detentor do maior potencial de abrangência, revelado pelos Atores Responsáveis descritos no quadro. As políticas em vigor para o esporte educacional na esfera federal têm muito a revelar sobre o direcionamento do projeto histórico para o esporte enquanto elemento satisfador de cidadania a partir de sua intervenção educativa.

Todos os Programas do quadro acima apresentam em seu escopo indícios da presença do discurso mistificador apontado por Flausino e Mascarenhas (2012):

- " [...] democratizar o acesso à prática e à cultura do esporte de forma a promover o desenvolvimento integral de crianças, adolescentes e jovens, como fator de formação da cidadania e melhoria da qualidade de vida" (PST); ${ }^{28}$

\footnotetext{
${ }^{28} \mathrm{http}: / /$ esporte.gov.br/index.php/institucional/esporte-educacao-lazer-e-inclusao-social/segundotempo. Acesso: 10/03/2015.
} 
- " "[...] disseminação da prática esportiva e o desenvolvimento de valores olímpicos e paraolímpicos entre os jovens e adolescentes, numa perspectiva de formação educativa integral que concorra para a elevação do desempenho escolar e esportivo dos alunos" (Atleta na Escola) ${ }^{29}$;

- "o principal foco é o fortalecimento de hábitos e valores que incrementem a formação da cidadania com o intuito de ampliar o Sistema Nacional de Esporte para a formação de atletas de alto rendimento" (PST-Mais Educação) $)^{30}$

- "promover a inclusão social a partir do esporte, detectar novos talentos e criar um novo ambiente favorável à continuidade da prática esportiva no país. (Olimpíadas Escolares) $)^{31}$

No universo das políticas públicas esportivas onde o esporte educacional transita, o PST assume enorme protagonismo pela sua abrangência (ainda mais após o convênio estabelecido com o Mais-Educação), financiamento (apenas não recebe mais recursos no âmbito do ME que os destinados ao esporte de alto rendimento segundo MATIAS, 2014) e capital político. Bracht e Almeida (2013) entendem o PST, como um programa que vem para substituir o Programa Esporte na Escola de 2001, este por sua vez criado como resposta do Estado ao Vexame Olímpico de Sydney $2000^{32}$. O PST, segundo os autores, reproduz não apenas o modelo da pirâmide esportiva, mas também o discurso mistificador (FLAUSINO; MASCARENHAS, 2012) do esporte incluindo em sua proposta a obtenção da cidadania e solução de mazelas sociais. Nessa compreensão, afirmam que o esporte acaba por sobressair-se como um direito social a partir de uma perspectiva liberal-funcionalista, pois apregoa que seu acesso deveria ser ampliado em virtude de se apresentar como elemento de compensação dos efeitos colaterais da globalização econômica (BRACHT; ALMEIDA,

\footnotetext{
${ }^{29} \mathrm{https}: / /$ www.fnde.gov.br/fndelegis/action/UrlPublicasAction.php?acao=abrirAtoPublico\&sgl tipo=RES \&num ato $=00000011 \& \mathrm{seq}$ ato $=000 \& \mathrm{vlr}$ ano $=2013 \& \mathrm{sgl}$ orgao $=$ CD/FNDE/MEC. Acesso: 09/03/2015 ${ }^{30} \mathrm{http}: / /$ www2.esporte.gov.br/snee/segundotempo/maiseducacao/objetivos.jsp. Acesso: 10/03/2015 ${ }^{31}$ http://esporte.gov.br/index.php/institucional/alto-rendimento/jogos-escolares-brasileiros/olimpiadasescolares-2. Acesso: 10/03/2015

32 Este Programa tinha como objetivo a detecção de talentos esportivos na escola através das aulas de Educação Física escolar e foi duramente criticado pelos setores progressistas da Educação Física. Para maiores informações, Cf. SOUZA JÚNIOR, 2006 (disponível em http://www.revistas.ufg.br/index.php/fef/article/view/72/0, acesso em 10/03/2015)
} 
2013). Dessa forma, o esporte não é visto como um patrimônio da cultura, mas se justifica em virtude dos benefícios "instrumentais" que sua prática possibilita aos que com ele se envolvem como a reabilitação de pessoas em condições de risco, promoção da saúde da população, ou até, para alguns felizardos, a possibilidade de ascensão econômica. (BRACHT; ALMEIDA, 2013).

Eles criticam a incorporação do esporte à escola segundo os preceitos dos Sistema Esportivo nacionais, os quais segundo os autores, atendem às expectativas do próprio Sistema, mas, por sua vez desvinculam-se às expectativas do sistema educacional, desrespeitando suas especificidades, objetivos e autonomia. Essa lógica não responde a questionamentos próprios da natureza escolar e do esporte presente nas aulas de Educação Física como elemento da cultura corporal:

\begin{abstract}
É tarefa da escola a democratização do acesso ao esporte, como política pública do Ministério do Esporte? Como conciliar a prática do esporte nas aulas de Educação Física Escolar com sua vivência no Segundo Tempo? Como elas dialogam? Como estão articuladas no projeto político-pedagógico da escola? Não seria função da instituição de ensino, por meio da Educação Física Escolar, oferecer um tratamento diferenciado (pedagogicamente orientado) em seus espaços? (BRACHT; ALMEIDA, 2013, p. 135)
\end{abstract}

Eles problematizam a interferência do sistema esportivo nacional no esporte praticado nas escolas desde a década de 1970 que hodiernamente é representado pela gestão do ME no esporte educacional, por vezes amparados (ou legitimados) em parcerias intersetoriais com o MEC. Essas ações resultam na absorção/incorporação do esporte nas aulas de Educação Física sem o questionamento ou a reflexão necessária acerca das afinidades/compatibilidades e contradições/incompatibilidades entre o esporte mercadoria e o esporte elemento da cultura corporal, este submetido os signos e sentidos de uma prática pedagógica no interior da escola. O resultado disto, para eles, é a legitimação do esporte de alto rendimento neste espaço. Isso, em tempos de Megaeventos esportivos, denuncia uma ação orquestrada pelo Estado para referendar a sua predileção a essas políticas de Estado em oposição à (suposta) democratização do esporte.

Ao vincular-se a Educação Física Escolar ao sistema esportivo, a referência tende a ser não o esporte realizado como atividade promotora de saúde ou da sociabilidade ou, mesmo, como ocupação saudável do tempo livre, e sim aquele que é mais visível socialmente: o esporte de alto rendimento (modelo para as olimpíadas escolares) (BRACHT; ALMEIDA, 2013, p. 136). 
E alertam:

Mais do que representar as genuínas capacidades da nação, os megaeventos esportivos seguem fortemente orientados pelos interesses do mercado esportivo, seus lucros, monopólios e capacidade de pressão. É nesse sentido, aliás, que tal sistema reivindica apoio estatal. Instalou-se, no Brasil, uma parceria entre o poder público e a organização esportiva, que opera como um grande lobby econômico internacional, um verdadeiro governo internacional do esporte, que usa e (abusa) do poder (e do dinheiro) público. No caso brasileiro, isso está muito visível com as enormes quantias que o governo tem investido na realização dos megaeventos. (BRACHT; ALMEIDA, 2013, p. 139)

Mascarenhas (2012) acrescenta a esse raciocínio afirmando que a lógica dos Megaeventos esportivos aliado a estratégias políticas pontuais corroboram a presença de políticas que reforçam a lógica da pirâmide esportiva na Educação Física escolar, trazendo à baila a velha discussão que toma esta disciplina curricular como ambiente de formação de atletas e o esporte como elemento fundamental neste propósito. Segundo Mascarenhas (2012), tais ações têm ganhado respaldo a partir da introdução neste diálogo (ou poderíamos dizer embate) de novos atores como o CONFEF e o próprio $\mathrm{ME}$, trazendo o perigo de que se perca a autonomia da escola e do cerceamento da Educação Física escolar como espaço da cultura corporal, não apenas do esporte.

[..] a retomada da ideia de pirâmide esportiva e os perigos quanto à perda do projeto político-pedagógico da Educação Física para o esporte de rendimento, mais do que retórica e discurso, além de constituírem o cimento ideológico do bloco olímpico, ganham o contorno de política oficial. (MASCARENHAS, 2012, p. 61)

Ações governamentais como o PST-Mais Educação junto ao Ministério da Educação (MEC) vem corroborar a expansão intersetorial de programas do ME. Por sua vez, o avanço de setores conservadores como o Sistema CREF/CONFEF sobre ações políticas junto à Câmara dos Deputados, o próprio MEC e o Conselho Nacional de Educação (CNE) e ao ME para pleitear o credenciamento de professores que atuam junto aos Jogos Escolares e Jogos Universitários (MASCARENHAS, 2012) constituem-se ações perniciosas à autonomia da escola em relação à lógica da competitividade, presente no esporte e alto-rendimento 
Ampliando a análise para outra ação descrita no quadro, Bueno (2008), ao analisar os investimentos do governo federal com esporte escolar de 2003 a 2008 afirma que estes estiveram voltados de forma privilegiada para a realização dos Jogos Escolares, o que sobremaneira valoriza a perspectiva do esporte de rendimento, contradizendo, conforme verificamos, a formação para a cidadania, pois privilegia o rendimento, performance, competição, espelhando a perspectiva de esportemercadoria. Em relação a totalidade dos gastos, Bueno (2008) anuncia o que foi demonstrado posteriormente por Athayde (2011), o seu direcionamento majoritário para o esporte de alto rendimento (EAR):

Gráfico 1 - Gasto com esporte realizado pelo governo federal entre 2003 e 2008. (extraído de BUENO, 2008, p. 240)

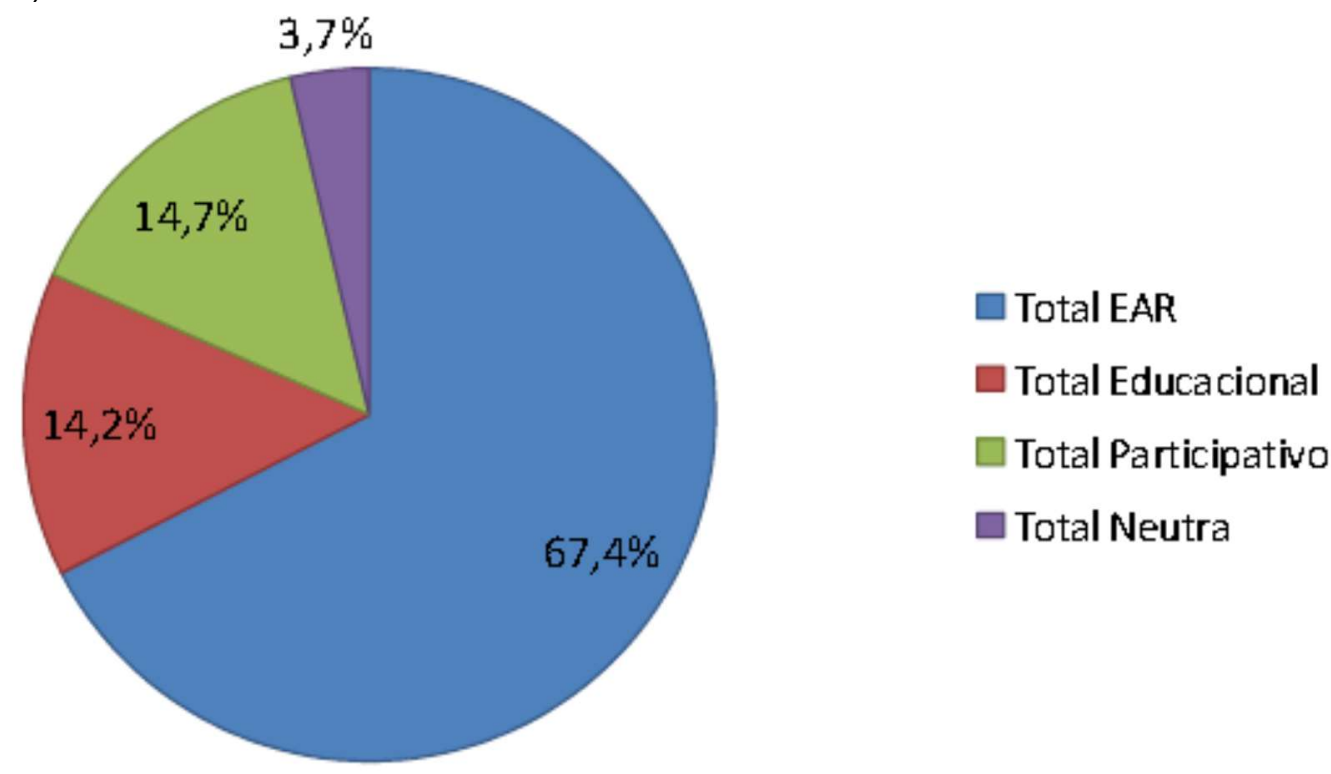

Bueno (2008) explica que do total de gasto na categoria EAR, entre $2003 \mathrm{e}$ $2008,65,4 \%$ foram referentes a despesas com preparação e realização dos Jogos Pan Americanos Rio 2007, ou seja, Megaevento, demandando a contenção de gastos em outras áreas de investimento dentro da própria categoria EAR.

Em âmbito nacional, no período da democratização do esporte houve uma atenção maior à sua organização no âmbito institucional (relativo às modalidades, atletas e confederações) consolidando a liberalização deste produto cultural da humanidade em nosso país. A mais evidente preocupação com as políticas de esporte educacional, segundo Bueno (2008) não operou em contradição aos interesses do esporte de alto rendimento, pois este sempre o apanhou (em consonância à lógica da 
pirâmide esportiva) como sua fonte de matéria-prima, portanto, a valorização de uma possibilidade não colocaria em xeque a sua hegemonia.

Não obstante, a legitimação deste como um direito constitucional também reforçou a possibilidade de manutenção da "ordem esportiva", já que a coalizão e empenho a favor da valorização e reconhecimento da categoria esporte educacional não atingiu ou interferiu nos interesses representados pela categoria esporte de rendimento.

[...] situo a ação da Comissão e do CND como significativamente favoráveis a coalizão pró-EPE ${ }^{33}$, sem ter sido contra a coalizão pró-EAR. [...]Dos pontos que se tornaram favoráveis à coalizão pró-EPE e resultantes do processo constituinte, dois fazem parte dos aspectos secundários da estrutura de crenças e valores das duas coalizões[...]: o esporte como direito social ("direito de cada um") e o incentivo do Estado ao lazer (esporte participativo). Já o terceiro ponto, posto textualmente no inciso II do Artigo 217: "promoção prioritária do desporto educacional" está estabelecido como um dos aspectos centrais da estrutura de crenças e valores da coalizão pró$E P E$, o que o tornaria de difícil aceitação pela coalizão pró-EAR se esta tivesse tido a percepção de que isto ameaçaria sua predominância. (BUENO, 2008 , p. 253/254. Grifos originais)

A partir do exposto, infere-se que as políticas de esporte educacional engendradas pelo Estado brasileiro através de políticas públicas não correspondem às expectativas de ampliação de direitos de cidadania. Isso ocorre em virtude de sua aproximação das políticas focalistas e a mercadorização das políticas sociais, pois as mesmas coadunam com a manutenção da pobreza não apenas material, mas política e espiritual, uma vez que se distancia tal maneira da emancipação humana. Tais políticas parecem responder à lógica da desconstituição de direitos de cidadania e democratização, movimento observado nas últimas três décadas em reposta a organização do Estado neoliberal, Reestruturação Produtiva e Contra-Reforma do Estado.

Destarte, a não-universalização do direito ao esporte mesmo quando este se aproxima da sua possibilidade educacional, o afasta da possibilidade de se configurar em um efetivo direito social, corroborando a, se não maliciosa, abstrata ideia de que o esporte pode ser subdividido em manifestações distintas e (supostamente) antagônicas. Pois, o anunciado uso educacional do esporte através das políticas

33 O autor traz essa denominação para o esporte participativo e educativo (BUENO, 2008), categoria surgida ainda no período da ditadura militar que se colocava como contraponto ao EAR - esporte de alto rendimento. 
públicas tem servido para tornar mais robustas as injustiças sociais e o acúmulo de capital, distanciando-se da ampliação e universalização de direitos e da propalada emancipação humana.

No próximo capítulo nos aproximaremos da construção do direito ao esporte no Brasil em face a essa totalidade de complexos que permeiam a construção da sociedade brasileira no período democrático. 


\title{
Capítulo 2 - 0 direito ao esporte no Brasil
}

\begin{abstract}
O esporte jamais foi democrático no sentido original da palavra, isto é, uma prática cujo acesso e participação foram garantidos a todos sem distinção. Sua organização institucional jamais permitiu questionamentos e o apoio que recebeu raramente não foi direcionado às elites. Aliás, a ordem esportiva no Brasil, principalmente em suas origens, foi resistente a sua democratização, criando toda ordem de entraves para que o esporte pudesse ser praticado pelas classes populares (VERONEZ, 2005, p. 182)
\end{abstract}

Este capítulo está organizado em cinco atos, os quais dialogam com a história da construção do direito ao esporte no Brasil e a fundação de uma categoria elementar neste trabalho: o esporte educacional. Nesse caminho, a cena do primeiro ato descreve como o esporte se organizava em sua era pré-constitucionalização, quais eram seus marcos normativos, conceituais e seus atores. No segundo ato, vislumbraremos qual era o cenário sociopolítico da constitucionalização do esporte no Brasil, entendendo de que forma o capitalismo contemporâneo marcou a organização dos direitos sociais no período de redemocratização no país.

No terceiro ato, compreenderemos como a construção do direito ao esporte foi marcado por essas nuanças na época de sua constitucionalização e quais as correlações de forças presentes nesse processo. Já no ato seguinte, estabeleceremos uma maior aproximação à categoria que abarca nosso objeto de pesquisa, o esporte educacional, procurando compreender como este se organizou diante seu marco legal e institucional pós-constitucionalização. Finalmente, o último ato deste capítulo tem a intenção de descortinar o processo histórico e dialético no qual situa-se a produção e reprodução humana através da política, sob a luz da compreensão de Estado e política em relevantes autores que utilizam o método de Marx. 
$1^{\circ}$ Ato: A era pré-constitucionalização ${ }^{34}$.

As primeiras normas que apanham o esporte no Brasil como elemento que dispensa atenção do Estado nos remete ao Estado Novo, o $1^{\circ}$ Governo Getúlio Vargas na década de 1930. Contudo, bem antes disso, a disciplina Educação Física já se apresentava na vanguarda em relação à organização das práticas corporais sistematizadas no Brasil desde o final do século XIX, utilizando os métodos da ginástica e do esporte. Este último assume a dianteira em relação aos propósitos educativos da Educação Física a partir das primeiras décadas do século XX para não perdê-la mais até os nossos dias. É, portanto, extremamente relevante compreender o desenvolvimento destes dois entes (esporte e Educação Física) de forma indissociável para compreender a gênese das políticas esportivas de nossa contemporaneidade.

Ainda sem o status de ciência, mas como uma proposta educativa já sistematizada, Castellani Filho (1988) afirma que a Educação Física adentra e se consolida em território brasileiro com a contribuição decisiva das instituições militares. Esta disciplina era compreendida como

\footnotetext{
Um elemento de extrema importância para forjar aquele indivíduo "forte", "saudável", indispensável à implementação do processo de desenvolvimento do país que, saindo de sua condição de colônia portuguesa [...] buscava construir seu próprio modo de vida. (CASTELLANI FILHO, 1988, p. 39)
}

Assumiu uma relevância estratégica nacional, não somente para estimular o controle higiênico e sanitarista da população, mas também na perspectiva de incutir uma "cultura modernista do corpo", em superação ao "corpo colonial" - um corpo saudável, robusto e harmonioso versus um corpo relapso, flácido e doentio (CASTELLANI FILHO, 1988). A disseminação da ideia de uma nova raça, especialmente de superioridade branca e com valores burgueses era também difundida a partir do Estado e reconhecida como eugenia (IDEM).

\footnotetext{
${ }^{34}$ Não pretendo aqui aprofundar em nuanças acerca da história do esporte no Brasil, mas sim tentar demonstrar como as legislações e políticas de esporte começam a se organizar a partir da intervenção do Estado, assim como as perspectivas que lhe permitiram tal possibilidade, com ênfase na política. Para maiores detalhes, sugiro LINHALES, 1996; CASTELLANI FILHO, 1999; MANHÃES, 2002; VERONEZ, 2005; BUENO, 2008.
} 
Castellani Filho (1988) reporta que uma das primeiras iniciativas do Estado, ou oriundo deste, para a questão das práticas corporais foi o Parecer 224 de Rui Barbosa, proferido na Câmara dos Deputados em 1882. O mesmo, denominado "Reforma do Ensino Primário e várias instituições complementares da Instrução Pública" defendia efusivamente a Educação Física nos programas escolares. E esse parecer, segundo o autor, serviu de referência para que se defendesse a presença da Educação Física no sistema escolar brasileiro, a qual se assentava sobre os preceitos da eugenia, higienismo e sanitarismo, especialmente para controle e aperfeiçoamento da "nova" classe trabalhadora, os escravos recém-alforriados na abolição da escravatura.

Entre o final do século XIX até a terceira década do século XX a Educação Física se inseriu no componente curricular do ensino primário e secundário brasileiros, segundo Castellani Filho (1988), impulsionado por esta iniciativa de modernização da sociedade brasileira, na transição de uma sociedade essencialmente rural e agrária para uma nova, urbano-industrial.

\begin{abstract}
Calcado nas mudanças que se processavam no modelo sócio-econômico, vemos reforçado, no concernente à Educação Física, sua estreita relação com os propósitos de eugenização da raça brasileira, com nuances que espelhavam um tímido início de seu distanciamento das questões próprias da higiene [...] revestindo-se de tinturas que a identificavam, cada vez mais, com os cuidados para o desenvolvimento do físico, num movimento consentâneo às mudanças sociais e econômicas aludidas. (CASTELLANI FILHO, 1988, p. 73)
\end{abstract}

Ao tempo que as práticas ginásticas e de educação do corpo entravam na agenda em território brasileiro através da Educação Física, na Europa ganhava força e robustez o fenômeno esporte. O chamado "esporte moderno", aquele organizado tal como conhecemos hoje, carrega em seus princípios a competitividade, associativismo, racionalização e burocratização, é oriundo da Inglaterra do século XIX. Foi fundado, segundo Bracht (2005), sob os preceitos da competição, rendimento físico-técnico, recorde, racionalização e cientifização do treinamento. O autor descreve que o esporte moderno reproduz alguns dos valores da sociedade capitalista, posto ser conterrâneo e contemporâneo da revolução industrial inglesa, berço da burguesia industrial e do capitalismo. O esporte ganhou, neste país, hegemonia das práticas corporais no seio das instituições escolares, pois na escola que ele pode ser praticado sem ser confundido com simples práticas populares, as quais eram sinônimas de arruaças ou ameaça à propriedade e à ordem pública. 
Segundo Betti (1991), o movimento esportivo inglês do século XIX auxiliou a formar "o outro pilar da sistematização da moderna Educação Física, e guarda relação com as transformações sócio-econômicas produzidas pela Revolução Industrial naquele país a partir de 1760" (BÉTTI, 1991, p.44). Para o autor, no século XIX houve um movimento de exportação do modelo esportivista inglês para o resto do mundo, tendo como carro chefe os jogos (os quais à medida que se desenvolviam e se tornavam mais complexos ganhavam o status de esporte como o futebol e o críquete, por exemplo), o associativismo e da Educação Física, que adotava na prática dos jogos esportivos um modelo de educação moral, cívica e corporal, todos úteis ao desenvolvimento da nação e do próprio modelo capitalista.

A dinâmica do desenvolvimento do esporte moderno e de sua vinculação quase "siamesa" à Educação Física no Brasil na intenção de forjar uma nova raça vinculada a propósitos urbano-industriais pode ser compreendida através de Bracht (2005), quando este afirma:

Seja como for, o surgimento do esporte moderno que está intimamente relacionado com o advento da moderna pedagogia, do nacionalismo, da problemática do lazer e do trabalho, sempre traz à tona dois outros conceitos centrais para o seu desenvolvimento: racionalização e orientação para o rendimento (Eichberg, 1979, p. 89). Por sua vez, a orientação para o rendimento e o record, inscreve-se na crença moderna do crescimento e progresso ilimitados. (BRACHT, 2005, p. 105)

Já Bueno (2008) lembra que o esporte surge no Brasil com contornos de utilitarismo inclinado ao controle eugênico e higienista. Ele afirma que o termo eugenia em nosso país tinha uma conotação ampla, "sendo associado também com a higiene social, mas acentuadamente, como em outros países, estava relacionado a concepções racistas disfarçadas em discurso científico" (BUENO, 2008, p. 83/84). higienismo, segundo o autor, ganhava tamanha proporção no pensamento social da época que a Constituição de 1934, em seu artigo 138, atribuiu aos três entes federativos o estímulo à educação eugênica e o cuidado com a higiene mental.

Castellani Filho (1999) ajuda a compreender como se deu esse movimento. O autor argumenta que na Era Vargas o esporte ganhou contornos de política de Estado, a partir de duas compreensões de corpo, posto, de homem: o primeiro, higiênico/eugênico, que 
[...] tinha na Política de embranquecimento da raça brasileira o seu principal trunfo para o estabelecimento de uma outra correlação de forças que viesse impedir os portugueses com vocação recolonizadora, de manipularem o contingente populacional de negros cativos (CASTELLANI FILHO,1999, p. 20 Grifos originais).

O segundo modelo, o corpo produtivo, incorporou os valores acima:

Outros valores que fizeram por reforçar sua relação com a questão da eugenia da raça, na medida em que o colocaram a serviço da defesa da Pátria frente aos denominados inimigos internos, questionadores do ordenamento sócio-político vigente [...], e aos inimigos externos, face a iminência da eclosão da $2^{\mathrm{a}}$ Guerra Mundial e do envolvimento brasileiro nela. (CASTELLANI FILHO, 1999, p. 21)

Também havia, segundo o autor, a intenção de assegurar a formação, preparação e manutenção da força de trabalho do povo brasileiro. Bueno (2008) corrobora esse raciocínio quando descreve que o Estado Novo, ao regulamentar e elaborar políticas de Educação Física, ensejava uma nova ideologia que conduzisse a sociedade rumo a uma modernização urbano-industrial e o desenvolvimento de valores nacionalistas e ufanistas.

Mas, além da intenção de legislar sobre a formação e possibilidades do corpo do trabalhador, o Estado na Era Vargas ocupou-se também, segundo Castellani Filho (1999) de controlar a sociedade civil ao promulgar legislações acerca da organização esportiva no país, fundamentados na imperiosidade, segundo o autor, de "disciplinar" e "pacificar" o esporte brasileiro para que este se adequasse à ordem social dominante.

O cenário dessas ações, especialmente das políticas que versavam sobre a organização do esporte, segundo Bueno (2008), era pintado com as cores da liberalização, rupturas, desorganização e rivalidades regionais que se apresentavam no âmbito do esporte nacional. Defendia-se que o Estado deveria organizá-lo, já que o chamado "amadorismo" do esporte era fortemente questionado, tendo em vista que as ações privadas (clubes e associações) viam seu futuro prejudicado em virtude de sua insustentabilidade financeira acrescida da rivalidade entre seus dirigentes, tanto em âmbito estadual, municipal ou até mesmo interassociações.

Através desse movimento de organização e profissionalização do esporte o Estado encontrou nesta oportunidade uma chance de propagar sua intenção para o desenvolvimento nacional, chamando para si "a responsabilidade de normatizar, controlar e utilizar as entidades esportivas de acordo com a sua orientação ideológica 
nacionalista." (BUENO, 2008, p. 106). Nesse movimento, as entidades esportivas já estabelecidas, em especial o futebol através dos estados do Rio de Janeiro e São Paulo, aderiam e protagonizavam essa questão do profissionalismo. É importante destacar a influência desses estados na Confederação Brasileira de Desportos $(C B D)^{35}$ através de suas federações de futebol:

A questão foi mediada e resolvida pela intervenção do Estado, em 1933, a favor da profissionalização de certas modalidades, entre elas o maior ponto de divergência, o futebol. "Chamado de 'amadorismo marrom', o profissionalismo por longo tempo esteve no centro das discussões acerca do esporte: para os puristas era um desvio infame, para os concordes, um meio legítimo de ganhar a vida." (SANTOS J. A., 2000, apud BUENO, 2008, p. 101).

Em verdade, no governo Vargas a prática organizada do esporte através das federações ${ }^{36}$ e confederações esportivas tinham como pano de fundo o controle social, tendo em vista que essa organicidade excluía os proletários, pobres e negros. Por isso, o apelo ao amadorismo era forte:

\begin{abstract}
O apelo amadorista foi em realidade uma estratégia da camada dominante e de seus atletas para evitar que plebeus, principalmente negros e mestiços, adentrassem a esfera até então reservada à elite. Fato que reforça a existência do racismo. O principal ponto a favor deste argumento é o fato de o tênis, até recentemente tido como esporte de elite, ter sido também profissionalizado, no mesmo momento sem sofrer maiores oposições, pois a profissionalização deste esporte não representava ameaça por ser modalidade inalcançável aos "inferiores". (BUENO, 2008, p. 101)
\end{abstract}

Diante deste cenário, Veronez (2005) nos auxilia a compreender como o esporte tornou-se um dos instrumentos estratégicos para o Estado Varguista expandir seu projeto de desenvolvimento nacional, reforçando o modelo de organização

\footnotetext{
${ }^{35}$ A CBD fora criada em 1916 por iniciativa do Estado brasileiro com a intenção de dar organicidade ao esporte, especialmente em virtude das desavenças entre dirigentes esportivos ligados ao futebol do estado de São Paulo, esporte elitista, na ocasião. Bueno (2008) afirma que desde essa época os dirigentes esportivos da CBD já defendiam independência da entidade, mas não dispensavam as subvenções do Estado. A CBD, pela força que possuía e também por ser a única Confederação eclética prevista no Decreto-Lei 3.199, ajudou a compor as fileiras do órgão máximo (e absoluto) do esporte criado por Vargas, o CND - Conselho Nacional de Desportos (MANHÃES, 2002).

${ }^{36}$ O Futebol já vivenciava um movimento de profissionalização engendrado por seus dirigentes e também atletas, assumindo a vanguarda desse movimento. Manhães (op. cit.) afirma que a profissionalização é uma iniciativa de pressuposto liberal, tendo em vista a organização fundada em direitos privados e de livre associação das entidades esportivas, portanto, com pretensões de manterse a parte do controle do Estado.
} 
capitalista através das ações de modernização urbano-industrial da sociedade brasileira:

\begin{abstract}
Um novo padrão de intervenção estatal no esporte - totalitário, centralizado, burocrático e corporativista -, do mesmo modo que nas demais esferas da vida social, começou a ser implementado num momento específico de desenvolvimento do capitalismo no nosso país, de acirramento de interesses entre uma burguesia rural e uma industrial, em que o Estado está sob o controle destas últimas, porém, sem apresentar as condições de hegemonia necessárias para protagonizar a elaboração e implantação de um projeto de modernização da sociedade. Para consolidar e preservar seu poder social e seu poder político, essa burguesia, por meio de um pacto interelites, concentra poder "na cúpula governamental e administrativa" (POULANTZAS, 2000 , p. 233) do governo que, por sua vez, expande em quantidade e qualidade o seu domínio, criando e intervindo em diversos aparelhos para assim fazer surgirem as condições de consenso e de melhor reproduzir as relações de dominação/subordinação necessárias e típicas do modo de produção capitalista, cujos tentáculos alcançam, a partir de então, o aparelho esportivo. (VERONEZ, 2005, p.171)
\end{abstract}

Esse padrão de organização do esporte a partir do Estado iniciado pelas mãos do governo Vargas iluminou uma longa trilha intervencionista que, certamente perdura até hoje, conforme perceberemos adiante. Se de forma inovadora no país Vargas disciplinou, organizou e burocratizou o esporte a partir de preceitos que remetiam a ordem de organização burguesa, os governos subsequentes não somente deram continuidade a estas ações como também aprofundaram as possibilidades de controle social através da relação Estado-esporte.

Manhães (2002) ilustra que o Decreto-Lei 3.199 de $1941^{37}$, primeira legislação esportiva brasileira elaborada no governo Varguista cujas linhas estabeleceram as bases de organização dos desportos em todo país, surgiu em resposta a necessidade premente de disciplinar e organizar o esporte nacional em face de seu projeto de desenvolvimento da nação. Após o discurso de Gustavo Capanema, ministro da Educação e Saúde em 1940, em defesa da burocratização da vida esportiva no país na intenção de que o esporte brasileiro ganhasse inserção e competitividade no cenário internacional, o governo aderiu à sua proposta de disciplinar o esporte brasileiro no sentido de conferir "racionalidade" e "eficácia operativa" na concepção desta legislação (MANHÃES, 2002).

\footnotetext{
${ }_{37}$ Pode ser conferida na íntegra em http://www2.camara.leg.br/legin/fed/declei/1940-1949/decreto-lei3199-14-abril-1941-413238-publicacaooriginal-1-pe.html . Acesso: 26/09/2014.
} 
Outro movimento que redundou nesta primeira legislação completa sobre o esporte nacional foi a questão do controle estatal acerca do movimento de profissionalização engendrado nas esferas do esporte por algumas Federações estaduais e organizações de atletas e dirigentes. Na intenção de organizar o que Rua (2012) denomina "estado de coisas", o Estado optou por agir e disciplinar essa questão lançando mão da estratégia de controle social através desta iniciativa.

Ou seja, a que projeto de ordem social corresponde a perspectiva disciplinadora do estado perante a sociedade civil, naquele momento, e a que universo refere-se 0 ato disciplinatório de forma mais ampla. São dados fundamentais para a explicitação da iniciativa de legislar sobre os desportos (MANHÃES, 2002, p. 31)

A criação do Conselho nacional de Desportos (CND) logo no $1^{\circ}$ Artigo do Decreto-Lei 3.199, que tinha a função de "orientar, fiscalizar e incentivar a prática de desportos em todo país" (MANHÃES, 2002, p. 177) já indicava a forma autoritária e antidemocrática de controle do esporte no país logo na formação de seu conselho e nomeação de seu presidente (João Lyra Filho), realizada a esmo e sem caráter técnico ou meritocrático (MANHÃES, 2002), conforme preconiza a lógica liberal que rondava o espectro desta iniciativa. Manhães (2002) também menciona a subjacência das especificidades desta legislação ao controle do CND, este por sua vez sob o controle imediato da Presidência da República. Isto representa uma demonstração irrefutável do projeto social deste governo para a sociedade brasileira, posto em ação através da legislação para o esporte, de acordo com o autor:

Prevê o artigo $5^{\circ}$ do Decreto n 3.199 que "a discriminação das atribuições"
do conselho será regulada exatamente no "respectivo regimento a ser
baixado com decreto do Presidente da República". O que poderia responder
à imprecisão por nós colocada se não fosse redundante. Ou seja, o Estado
regulará os limites da intervenção do próprio Estado, e por decreto! [...] Ora,
se o nível de abstração dos quatro itens referentes à competência do CND
seria regulamentado pelo regimento e este determina que tudo deve ser feito
para que se garantam a integridade do Decreto No 3.199 e,
conseqüentemente, dos quatro itens, é legítimo afirmar que o CND pode tudo.
É plenipotente. (MANHÃES, 2002, p. 42/43)

Castellani Filho (2008) acrescenta que o Decreto-Lei 3.199 de 1941 inaugura um bloco que se estenderá até a década de 1970 do modelo de Estado interventor, sempre com características conservadoras (sendo possível afirmar, 
antidemocráticas), assentado não somente na perspectiva do controle social, mas também na lógica da pirâmide esportiva:

\begin{abstract}
Desde aquele período, a natureza da intervenção estatal é de caráter conservadora, pois estabelece uma estrutura esportiva na qual o parâmetro central está apoiado no modelo piramidal: sua base e seu centro só se justificam a fim de cumprir o objetivo do ápice da pirâmide, o esporte de alto rendimento. Em outras palavras, a base e o centro da pirâmide servem tãosomente para dar sustentação ao esporte de alto rendimento. (CASTELLANI FILHO, 2008, p. 134)
\end{abstract}

Essa legislação de 1941, segundo Castellani Filho (2008) foi renovada pelo governo militar de Médici em $1975^{38}$ reproduzindo o contexto de modernização conservadora e a essência da lei de 1941, modernizando tão somente aquilo que dizia respeito aos interesses do campo do marketing e do esporte classista, este sendo mantido no campo do amadorismo, segundo o autor, através do não-reconhecimento da profissionalização do campo esportivo. Entretanto, abriu-se uma janela para sua profissionalização ao permitir competições organizadas por federações e confederações esportivas. Também é destacada pelo autor a lógica da relação entre Estado e organização do "sistema esportivo" brasileiro. Este enxergava o esporte de competição, referenciados pelas Confederações, Federações, Ligas e Clubes como um modelo para a prática intervencionista e conservadora do Estado na questão do esporte.

A iniciativa do Estado que permitiu a concepção deste projeto de "modernização conservadora" (VERONEZ, 2005) do esporte foi o Diagnóstico da Educação Física e dos Desportos divulgado em 1971 e cujos resultados culminaram na elaboração desta nova Lei geral do esporte em $1975^{39}$, a qual modernizava a lei Varguista de 1941. O produto desta e de outras iniciativas para o esporte, lazer e

38 Lei 6.251 de 1975, regulamentada dois anos depois pelo decreto 80.228/77. Cf. em http://www2.camara.leg.br/legin/fed/lei/1970-1979/lei-6251-8-outubro-1975-357712publicacaooriginal-1-pl.html. Acesso: 26/09/2014.

39 Políticas e ações dos governos militares que abordavam o esporte e Educação Física: o Diagnóstico da Educação Física e dos Desportos no Brasil (1969-1971) e, em virtude deste, o Plano de Educação Física e Desporto (1971); reestruturação da Educação Física através da criação do DED (Departamento de Educação Física e Desportos), vinculado ao Ministério da Educação e Cultura (MEC); destinação de recursos para fomento do esporte, da Educação Física escolar e do esporte estudantil e universitário com repasses ao CND e FNDE, Programa Esporte para Todos (EPT), reestruturação de Sistema Esportivo Nacional (VERONEZ, 2005; BUENO, 2008) 
Educação Física nos governos militares é descrito por Veronez (2005) da seguinte forma:

Nos 21 anos em que perdurou o regime de ditadura militar no Brasil (19641985), o setor esportivo foi influenciado sobremaneira pela ideologia e interesses militares. Talvez tenha sido o período em que de forma mais ostensiva esse setor sofreu o aparelhamento e a instrumentalização a favor da sustentação de um projeto de sociedade e de legitimação da hegemonia dos grupos que se instalaram no poder. (VERONEZ, 2005, p.234).

As ações engendradas a partir do governo durante a ditadura militar tinham como caráter explícito o controle social e a legitimação da lógica do Esporte de Alto Rendimento, a partir do relatório do Diagnóstico da Educação Física e dos Desportos. O mesmo propunha o modelo da pirâmide esportiva e aproveitava para incitar uma forma de controle social através de iniciativas como o Programa Esporte para todos (EPT) e a autonomização das entidades esportivas, estes providos com concessões e subvenções do Estado. Mas, não somente isso, o regime também utilizava a popularidade da seleção brasileira de futebol para dar corpo ao seu projeto para a nação através da utilização do esporte como um exemplo da força e capacidade internacional do Brasil. Isso foi ilustrado por Ribeiro Jr. et. al. (2014) citando como exemplo a relação entre o presidente da CBD em 1970, João Havelange e o militar chefe de Estado na ocasião, Gal. Médici:

Para a alegria dos então 90 milhões de brasileiros e dos militares em ação, em 21 de junho de 1970 o Brasil goleou a Itália por 4 a 1 no estádio Azteca, na Cidade do México. A seleção saiu de campo perseguida pelos torcedores mexicanos que invadiram o campo e consagrada como o maior time de futebol de todos os tempos. Festa na caserna, comemoração no sofá de Havelange. Assim como havia feito em 1958 e 1962 quando o presidente da CBD ficara em casa - talvez para não dar azar e/ou morrer de tédio. [segundo os autores, este ojerizava as partidas de futebol e sempre acompanhava o esporte de sua casa ou de lugares onde pudesse estar confortável] No término da partida, o general Médici, torcedor do Grêmio e fanático por futebol, ligou para o apartamento do cartola, no Leblon, e determinou: queria colocar as mãos no troféu. Médici, famoso por acompanhar os jogos ouvindo um radinho de pilha, queria capitalizar ao máximo a popularidade da seleção. Imediatamente, Havelange tomou um avião e fez os jogadores descerem em Brasília com a Taça Jules Rimet, conquistada pelo Brasil de forma definitiva com o tricampeonato. (RIBEIRO JR. et. al., 2014, p. 44/45)

$\mathrm{Na}$ esteira do sucesso do esporte de alto rendimento no país, uma das propostas do Diagnóstico da Educação Física e Desportos em 1971, que embasou a Lei № 6.251 de 1975 e que ganham destaque por sua repercussão e perenidade foi 
o modelo da pirâmide esportiva. Este modelo representou não somente uma forma de intervenção do esporte na escola, mas uma série de ações planejadas para a Educação Física escolar que apanha o aluno como potencial atleta e a escola como lócus privilegiado para a formação da base do sistema esportivo de alto rendimento. Isso porque, não somente instrumentaliza os alunos para a prática das modalidades, mas também amplia a prática espontânea na perspectiva do lazer, atraindo novos consumidores e ampliando a base da pirâmide, segundo Bueno (2008).

Figura 1 - Pirâmide Esportiva prevista no Diagnóstico da Educação Física e Desportos do Governo Médici. (BRASIL, 1971, p. 20 apud VERONEZ, 2005, p. 239)

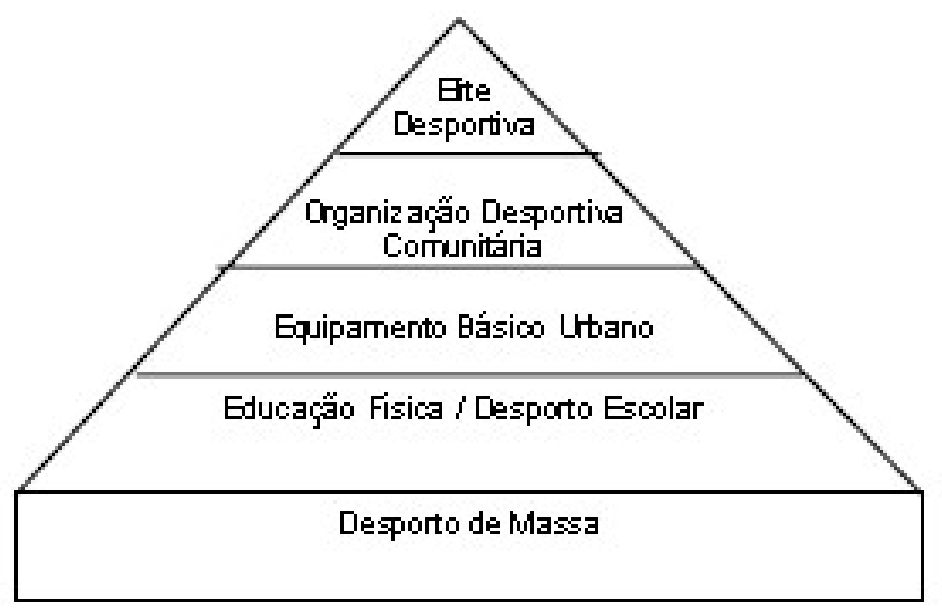

Bueno afirma que este modelo, proposto pelo Estado brasileiro em 1971 por intermédio do Plano Nacional de Educação Física e Desporto, assume a perspectiva do desenvolvimento da aptidão física e consequente rendimento técnico-desportivo, melhorando assim rendimento do país em competições internacionais. A escola e a Educação Física constituíram-se, para o autor, instrumentos fundamentais nesse objetivo:

A partir desta figura e da 'leitura ideológica' de seu significado, tornou-se comum no meio educacional esportivo um modelo derivado chamado de 'piramidal' que colocou o esporte escolar em sua base, o esporte de massa (lazer/recreação, condicionamento da população, etc.) como estágio intermediário e, no estágio superior, tido como prioritário para os governos de então, o esporte de elite ou EAR [esporte de alto rendimento]. (BUENO, 2008, p.142) 
Veronez (2005) afirma que este modelo, assim como todo o planejamento para a política Nacional de Esporte e o próprio Diagnóstico da Educação Física e Desporto tinham inspiração em modelos implantados nos países europeus que tomam como base o desporto de massa que tem como estágio superior o desporto de elite. A definição do Sistema Desportivo Nacional em 1971 foi ação fundamental neste processo, pois ele o organizava como estudantil, comunitário, militar e classista ${ }^{40}$. A expansão e, por assim se dizer, fomento do esporte para as práticas educativas atendia, segundo o autor, não somente ao pressuposto de integração de todo o sistema, desenvolvendo diferentes setores da sociedade de uma só vez, mas também à expectativa de controle social, pois o diagnóstico apontara que o esporte era "usado abusivamente para atender a interesses particulares de instituições como a Igreja e até partidos políticos" (VERONEZ, 2005,p. 240), havendo a necessidade, portanto, de conferir-lhe caráter educativo, ou por que não dizer, controle social.

Bracht e Almeida (2003) também percebem a incorporação do esporte escolar ao Sistema Esportivo Nacional como funcional ao sistema do esporte de rendimento, afirmando que a tensão entre o papel da Educação Física escolar e o esporte nela presente atendem ao sistema esportivo ao configurar-se na base da pirâmide.

\begin{abstract}
Se nos reportarmos à recente história da Educação Física brasileira, notadamente a partir da década de 1970 , constataremos que as políticas públicas, principalmente a federal, encaminhou uma incorporação do esporte escolar ao sistema esportivo nacional, sendo aquele, em muitos casos, orientado pelos órgãos que possuem vinculações com o sistema esportivo stricto sensu. Estabeleceu-se uma relação de mútuo condicionamento: ao componente curricular Educação Física é colocada a tarefa de funcionar como o alicerce do esporte de rendimento, sendo considerado a base da pirâmide; e a instituição esportiva, com o discurso da saúde e da educação, lança mão desses argumentos para conseguir apoio e financiamento público e alcançar legitimidade social. (BRACHT e ALMEIDA, 2003, p. 91)
\end{abstract}

Veronez (2005) ainda pondera que apesar desse modelo ter sido questionado no início da década de 1980 e mudanças terem sido ensejadas no âmbito da Seed/MEC ${ }^{41}$, não houve diferenciação nas políticas para os setores do esporte de rendimento e do desporto escolar, pois sua estrutura e organização tinham como referência o desporto de alto nível. Uma lógica perversa, avalia o autor, pois ambos

\footnotetext{
40 Lei n. ${ }^{\circ} 6.251 / 1975$ (VERONEZ, 2005.)

41 Secretaria de Educação Física e Desportos do Ministério da Educação e Cultura (ibid.)
} 
deveriam ter (como efetivamente têm) suas especificidades e peculiaridades. $E$ recorda uma situação corriqueira na prática do "desporto escolar":

\begin{abstract}
A perversidade dessa proposta se manifestava nas formas em que foi concretizada. As melhores escolas, tanto públicas quanto privadas, que dispunham de equipamentos esportivos, implementaram a política estabelecendo nas escolas a ultraseletividade, pois participavam das equipes representativas os melhores talentos esportivos. É preciso dizer que tais escolas geralmente estão localizadas em regiões centrais das cidades e o perfil de seus estudantes é de classe média. Nas escolas que não dispunham desses equipamentos, ou seja, a maioria das existentes no país, conforme constatou o diagnóstico de 1971, localizadas nas periferias e com um perfil de alunos oriundos de classes populares, ou a política não foi implementada ou foi "adaptada" às condições das escolas. (VERONEZ, 2005, p. 253)
\end{abstract}

Isso reproduz, segundo o autor, a lógica da ideologia liberal, a qual anuncia que em (supostas) iguais condições na concorrência se destacariam os mais aptos, ou no caso, os grandes talentos esportivos, reproduzindo na escola as relações sociais de produção.

Durante o os longos "anos de chumbo" o esporte se consolidaria como instrumento de legitimação de interesses nacionalistas/ufanistas envolto pela ideologia do controle social, melhoramento da raça (eugenismo) e da melhoria da aptidão física e saúde de seus praticantes (higienismo). O interesse em se desenvolver e aprimorar esse pensamento sempre esteve atrelado a grupos organizados que detinham a direção da sociedade. Ao perceber a influência deste produto da cultura humana nos cidadãos e cidadãs, as classes dirigentes ao normatizá-lo, discipliná-lo e torná-lo alvo de ações em forma de políticas o fizeram de forma a perpetuar seus interesses classistas. Manhães (2002) compreende que as pessoas ligadas à organização do esporte respondem a um interesse tacanho e sectário, alienando o sentido verdadeiramente democrático que esta manifestação poderia trazer.

Todavia, novas possibilidades emergiam na roda dialética da história. Com o processo de esgotamento da ditadura civil-militar e da redemocratização do Brasil, a Educação Física escolar e a prática do esporte em seu interior passariam por um período crítico / renovador (BRACHT, 1999) que os repensou de forma a inseri-los em uma possibilidade educativa e democrática, ao contrário da perspectiva do eugenismo, higienismo e controle social, dessa forma, concebendo o esporte como um direito institucionalizado. Não obstante, em consonância ao movimento 
liberalizante presente naquele momento de construção de uma nova sociedade democrática brasileira, outros interesses (nem tanto democráticos) também se destacavam. A lógica que orientou esses interesses será discutida no próximo ato.

\section{$2^{\circ}$ Ato - 0 cenário da redemocratização}

O país atravessava no momento de discussão e normatização do esporte como direito (década de 1980) uma forte onda neoliberal, com a Reestruturação Produtiva, a Contra-Reforma do estado oriundas da crise do capital a partir da década de 1970 e suas consequências: altos índices de desemprego, corte nos direitos sociais, precarização do trabalho e mundialização do capital sob a égide de uma renovada formar de organização do capital: o neoliberalismo. Nesse sentido, a regulação do Estado sobre os diversos setores da sociedade, o esporte incluído, inclinou-se conforme ponderou Veronez (2005) para a liberalização do setor.

\footnotetext{
Podemos observar que a inserção do esporte como um elemento das políticas públicas, após 1988, enquadrou-se na lógica mais ampla da atuação social do Estado, que não implica uma intervenção na economia de forma significativa (revertendo as desigualdades), salvo "para reforçar a lógica capitalista (contribuindo para a valorização do capital) por meio de alguns poucos benefícios, concedidos no mais das vezes em caráter emergencial, outorgados àqueles prejudicados pelo mercado" (PASTORINI, 2000, p. 212 apud VEVONEZ, 2005, p. 64).
}

O cenário sociopolítico na ocasião da constitucionalização do esporte no Brasil e, por conseguinte, das políticas decorrentes dela era o da Reestruturação Rrodutiva, modo de legitimação da forma de organização neoliberal iniciada nos países de capitalismo central e exportada para os demais países capitalistas do mundo e, após a queda do muro de Berlim em 1990, também de forma irrestrita a todo o globo terrestre (MONTAÑO e DURIGUETTO, 2010). Behring e Boschetti (2011) avaliam que a década de 1980 marcou uma revolução tecnológica e organizacional no sentido de buscar um diferencial na produtividade do trabalho que assegurasse a fonte de lucros denominado Reestruturação Produtiva. Também marcou essa fase o desemprego crônico associado a um intenso processo de desorganização dos trabalhadores, encerrando o que as autoras chamam "anos de ouro" do capitalismo. 
Os "anos de ouro", compreendidos entre o pós-guerra (1945) até o fim dos anos 1960 foi marcado pelos altos ganhos de produtividade do sistema capitalista combinados com ganhos no salário real que, segundo as autoras, incidia na "redução da jornada de trabalho, permitindo a manutenção do pleno emprego ao lado da rentabilidade do capital" (BEHRING; BOSCHETTI, 2011, p. 123). Além de bons salários e pleno emprego, essa época também combinava intensa proteção social, amplo consumo e expansão da economia. A sustentação política para esse equilíbrio era o controle social conhecido como welfare state, ou estado de bem-estar social combinado com o sistema de acumulação keynesiano-fordista ${ }^{42}$ :

O keynesianismo e o fordismo, associados, constituem os pilares do processo de acumulação acelerada de capital no pós-1945, com forte expansão da demanda efetiva, altas taxas de lucros, elevação do padrão de vida das massas no capitalismo central e um alto grau de internacionalização do capital (BEHRING; BOSCHETTI, 2011, p. 88)

A Reestruturação Produtiva indicou não somente o esgotamento do sistema de regulação keynesiano-fordista, mas também a redução do crescimento econômico, recessão, enfraquecimento das políticas sociais, desemprego, desigualdade social e desarticulação da classe trabalhadora. A lógica de organização do Estado que capitaneou a implementação dessas mudanças foi o neoliberalismo ${ }^{43}$, que preconizava a livre regulação do mercado, contenção dos gastos estatais (principalmente com proteção social) e reforma fiscal, essencialmente para manutenção das taxas de lucro (BEHRING; BOSCHETTI, 2011). Para os neoliberais, "a proteção social garantida pelo Estado social, por meio de políticas redistributivas é perniciosa para o desenvolvimento econômico" (IDEM, p. 126).

\footnotetext{
42 Fordismo: desenvolvido por Henry Ford, introduziu o modo de produção em massa visando o consumo em massa, a partir da lógica de produtividade no trabalho. Elementos básicos (ANTUNES, 2011): produção em larga escala através da linha de montagem, controle da linha de produção (tempo e movimentos), trabalho parcelar e fragmentado, separação entre elaboração e execução. Keynesianismo: intervenção do Estado para reavivar a produção, partiu da proposta do economista John Maynard Keynes (1936, apud ANTUNES, 2011). Este rompia com o pensamento conservador à época incluindo nas suas estratégias de manutenção das taxas de lucro e da economia de mercado às políticas sociais. Ao Estado, cabia a garantia do pleno emprego e maior igualdade social, assumindo protagonismo na administração macroeconômica - produção e regulação das relações econômicas e sociais (BEHRING e BOSCHETTI, 2011)

43 O primeiro articulador do pensamento neoliberal foi Frieidrich Hayeck em 1944 e sua intenção era combater o keynesianismo e solidarismo presentes no welfare state europeu e no New Deal norte americano, assim como o poder dos sindicatos e do movimento operário que pressionavam a base de acumulação capitalista com suas crescentes reivindicações por melhores salários e políticas sociais. (ANDERSON, 1995)
} 
Montaño e Duriguetto (2010) ressaltam que o período após o esgotamento dos "anos de ouro" e a crise do capitalismo na década de 1970 inauguram o Regime de Acumulação Flexível, nomenclatura denominada por David Harvey em 1993 que indica a hegemonia do capital financeiro sobre o capital produtivo e, para os autores, perdura até hoje, certamente sendo decisivo no processo da construção e desenvolvimento dos direitos sociais em nosso país. Segundo o raciocínio dos autores, os elementos fundamentais para o surgimento desse Regime seriam:

1. A crise do capital mundial na década de 1970, gerada por fases de superprodução e superacumulação. Amparados por Mandel (1977; 1982 apud MONTAÑO; DURIGUETTO, 2010), descrevem a superprodução como "uma interrupção no processo de reprodução ampliada por uma queda na taxa de lucro" (p. 184), ou seja, em decorrência do pleno emprego e atividade produtiva há mais oferta do que demanda de produtos. Já a superacumulação é referente ao excesso de capital proveniente dos lucros, onde este excesso não tem condições de ser reinvestido. A consequência disto seria a ampliação da extração de mais-valia absoluta, fuga de capitais para outros países, diminuição de investimento na atividade produtivo-comercial e sua realocação para a atividade financeira;

2. O aumento do capital especulativo gerado por essa expansão financeira através da abertura dos mercados nacionais ao capital excedente, forçando esses estados a abrirem mão de posturas protecionistas e diminuírem gastos sociais para a geração de superávti primário. O resultado desta iniciativa, segundo os autores, pode ser considerada a crise do regime de acumulação fordista/taylorista;

3. A consolidação, a reboque dessas investidas do capital, do projeto neoliberal que segundo os autores, constituiu-se em "uma estratégia que anulasse as conquistas trabalhistas e que permita a superexploração do trabalho como um todo" (MONTAÑO; DURIGUETTO, 2010, p. 192). Eles ainda ressaltam que este projeto é uma estratégia viável para a reestruturação do capital, que se consolidou em três frentes: a ofensiva contra o trabalho, a Reestruturação Produtiva e a reforma (ou Contra-Reforma) do Estado. 
A Contra-Reforma do Estado, segundo os autores, corresponde ao ajustamento realizado no âmbito administrativo-funcional para desimpedir ou desregulamentar os mercados liberando-o para livre atuação, mas com a proteção política-institucional dos Estados nacionais. Está articulada à Reestruturação Produtiva e retomada das altas taxas de juros, assumindo tal maneira um caráter político, econômico e ideológico cuja intenção seria esgotar o estado de bem-estar social (welfare state) e o regime de acumulação fordista-keynesiano. Os autores compreendem como estratégias desta Contra-Reforma do Estado os chamados

[...] "ajustes estruturais" de orientação monetarista e neoliberal, nos planos econômico, social e burocrático-institucional, que os Estados nacionais, a partir fundamentalmente das atuais pressões e exigências das instituições financeiras internacionais de Bretton Woods (FMI, BM e Bird), tiveram que implementar como condição para receber os empréstimos e os investimentos produtivos dos capitais financeiros e das multinacionais. A realização desses "ajustes" é posta como o passaporte para inserção de um país na dinâmica do capitalismo contemporâneo (MONTAÑO e DURIGUETTO 2010, p. 205. Grifos originais).

A construção dos direitos sociais no Brasil a partir da Carta Magna de 1988 estavam imbuídas dessas disputas impostas pela dinâmica internacional de reorganização do sistema capitalista. Sua maior expressão na América Latina foi o Consenso de Washington. Segundo Negrão (1998) fora o "conjunto de reformas neoliberais que apesar de práticas distintas nos diferentes países, está centrado doutrinariamente na desregulamentação dos mercados, abertura comercial e financeira e redução do tamanho e papel do Estado"44.

De acordo com Behring e Boschetti (2011), esse processo implicou na desregulamentação de direitos e cortes nos gastos sociais. Elas afirmam que essa lógica permitiu uma imensa reconfiguração dos direitos sociais, somado ao fato que o desemprego e a precarização do trabalho limitaram o acesso aos direitos respectivos aos empregos estáveis. O grande desenvolvimento econômico baseado no consumo engendrado no período da ditadura militar acirrava a desigualdade e as relações sociais no Brasil, o que de certa forma repercutia nas políticas sociais do Estado. $\mathrm{O}$ desenvolvimento abriu, segundo as autoras, uma dualidade em relação às políticas sociais especialmente nos campos da saúde, previdência e educação, abrindo esses

\footnotetext{
44 NEGRÃO, J. J. 0 consenso de Washington. Disponível em http://www.cefetsp.br/edu/eso/globalizacao/consenso.html. Acesso em 02/10/2014.
} 
campos para exploração privada: quem pudesse pagar levaria um serviço com qualidade diferenciada.

Nesse movimento a agenda neoliberal ditava suas premissas, que para as autoras ultrapassou a "década perdida" 45 . Contraditoriamente, esta também foi a década de avanços nos direitos sociais em virtude do processo de redemocratização e lançamento da "Constituição Cidadã", a qual colocava em pauta questões importantes como reafirmação das liberdades democráticas, impugnação das desigualdades, afirmação de direitos sociais, direitos trabalhistas, soberania nacional e reforma agrária. Esta disputa por hegemonia entre campos filosóficos/epistemológicos distintos se refletia no processo da redemocratização, onde interesses de setores vinculados à classe trabalhadora, a mais acometida pela crise do capital, conflitavam com interesses conservadores-liberais na elaboração da nova CF. Os debates para a consolidação e ampliação de direitos sociais (ou novos direitos, como é o caso do esporte), enfrentaram esse tensionamento no processo de sua concepção. Behring e Boschetti (2011) relatam que o sentido das mudanças após o surgimento de políticas sociais, no esteio da reabertura pós ditadura civil-militar e a retomada do Estado democrático de direito não permitiu que se ultrapassasse a lógica do Estado burguês, segundo elas uma cultura "visceralmente antidemocrática e conservadora" (p. 151), por isso difícil de ser consolidada na constituição cidadã.

As autoras afirmam que na consolidação desses direitos, ou digamos, de novos direitos como é o caso do esporte, os interesses da elite política e econômica, já organizados, predominaram. Isso acabou resultando, segundo as autoras, em uma "Constituição programática e eclética, que em muitas ocasiões foi deixada ao sabor das legislações complementares" (BEHRING; BOSCHETTI, 2011, p. 142). Linhales (1996) corrobora esse raciocínio ao afirmar que a construção do direito ao esporte guarda coerência com a conquista dos demais direitos no sentido da afirmação de interesses liberais, contemporizando-se como uma solução modernizadora (ainda que conservadora) de ocasião, ou ainda, nas palavras de Behring e Boschetti (2011) "uma espécie de híbrido entre o velho e o novo" (p. 142). Essas autoras asseveram que, apesar de inequivocamente terem havidos avanços na questão das políticas sociais, muito em virtude da nova cena democrática que se instalava, essa correlação de força

45 Os anos de 1980 são conhecidos como a "década perdida" em virtude do forte período de recessão da economia (BEHRING; BOSCHETTI, 2010). 
entre interesses das classes populares trabalhadoras, os mais progressistas, e as classes conservadoras demonstrou-se favorável a esta segunda, especialmente no campo das políticas sociais. Concluem:

\begin{abstract}
Nas nossas paragens não houve reformas no sentido social-democrata [sistema político europeu que dava sustentação ao modelo de acumulação keynesiano-fordista através das estratégias de welfare state], mas processos de modernização conservadora e revolução passiva (Coutinho, 1989). Tais processos promoveram mudanças objetivas nas condições de vida e de trabalho dos "de baixo" - o que incluiu o desenvolvimento de um Estado social - mas sempre contidas e limitadas diante das possibilidades, e sempre sob controle das classes dominantes, para manter em seu lugar as "classes perigosas", sem dividir o bolo dos saltos para diante (BEHRING; BOSCHETTI, p. 151)
\end{abstract}

Similarmente à construção dos direitos sociais, as iniciativas do poder público brasileiro nas discussões sobre o direito ao esporte seguiram uma tendência mundial de desqualificação das iniciativas populares na concepção de suas políticas. Como Boschetti (2009) afirma que para se compreender uma política é necessário considerar os caracteres históricos, pautados nas condições que compõe as múltiplas determinações do fenômeno, seguiremos este movimento para compreender o surgimento do esporte como direito constitucional. Após compreender seu pano de fundo, apreendendo o contexto político e socioeconômico não somente brasileiro, mas também mundial, está montado o cenário para o próximo ato.

\title{
$3^{\circ}$ Ato - A constitucionalização do esporte no Brasil
}

Na ocasião da redemocratização no Brasil emergia uma nova compreensão do esporte. Com o auxílio do processo de redemocratização e o movimento que alçou esta manifestação da cultura humana no rol dos direitos constitucionais, tendo ao pano de fundo o avanço do neoliberalismo e uma crise socioeconômica decorrente do processo de Reestruturação Produtiva, essa nova compreensão crítica do esporte consolidaria nesta época e até o período pós-Constituição de 1988, segundo Castellani Filho (2008), sua relação visceral com o Estado. 
Não apenas isso, mas também pode-se perceber uma disputa por hegemonia neste território entre uma tendência fortemente conservadora (a qual pregava a liberalização do esporte através de seus marcos legais aliado a subvenções do Estado) e outra que de vislumbrava avanços democráticos (garantir o direito ao esporte a partir da compreensão em múltiplas possibilidades de sua prática). De fato, esta última corrente que concebia as diferentes possibilidades de sua prática conseguiu avançar ao ponto de elevar suas discussões e deliberações ao ponto mais alto das tratativas legais, a Constituição Federal de 1988, ainda que a inserção do esporte no rol dos direitos constitucionais estivesse permeada por uma brecha intervencionista do Estado em relação ao esporte.

Para Castellani Filho (2008) vigorou neste processo a lógica do Estado neoliberal, que impulsionou o esporte ao mercado sob o pretexto de sua modernização e autogestão, demarcando legalmente sua personalidade jurídica e autonomia em relação à atuação e regulação do Estado. Segundo o autor, com o discurso de sair das asas do controle do Estado, portanto, da coisa pública, o esporte na verdade arrumava subterfúgios para, ao organizar-se autonomamente em relação a este, poder sustentar-se com sua ajuda: É fortalecida a ideia de a sua base organizativa deve dar-se tendo por
sustentáculo as entidades com personalidade jurídica de direito privado. Uma
entidade com personalidade jurídica de direito privado que não permite, em
nome de sua autonomia, a presença do Estado. Uma entidade que não
admite a intervenção do Estado, mas só funciona com recurso público; não
consegue funcionar sem o dinheiro público, não vive sem dinheiro público,
portanto vive o melhor dos mundos! O argumento de tais entidades é o
seguinte: "é o mercado que estabelece as minhas relações e por isso, como
entidade jurídica de direito privado, não admito intervenção estatal, mas
preciso do dinheiro público para existir, para cumprir minha finalidade social".
(CASTELLANI FILHO, 2008, p. 136)

Um marco importante da construção do direito constitucional ao esporte no Brasil que dá sentido a este raciocínio remete ao surgimento em 1985 - período de transição entre a ditadura cívico-militar e a democracia no Brasil - da Comissão de Reformulação do Esporte Brasileiro. Essa Comissão, presidida por Manuel José Gomes Tubino ${ }^{46}$, então presidente do Conselho Nacional de Desportos (CND),

\footnotetext{
46 Livre docente pela Universidade Estadual do Rio de Janeiro, faleceu em 2008. Ocupou diversos cargos em instituições internacionais de Educação Física e realizou trabalhos na área de Treinamento Desportivo, Performance esportiva e Esporte Participativo, além de produções acadêmica na área do esporte-educação. 
possuía em suas fileiras o Coronel Octávio Teixeira, seu secretário-executivo, Mário Amato (ex-presidente da Federação das Indústrias de São Paulo), Adhemar Ferreira da Silva, Edson Arantes do Nascimento (Pelé) e Maria Esther Bueno (ex-atletas), Carlos Arthur Nuzmam (então presidente da Confederação Brasileira de Vôlei e atual presidente do Comitê Olímpico Brasileiro), Fernando Sarney Filho (filho do presidente à época, José Sarney e então vice-presidente da CBF), entre outras pessoas de "notório saber esportivo" conforme pesquisou Veronez (2005).

Sobre esta Comissão, Linhales (1996) ressalta que a despeito desta gama heterogênea de atores que a compuseram, ela não pode ser considerada representativa da pluralidade de interesses que permeavam o setor esportivo, mas possuia respaldo institucional/político suficiente para garantir os interesses políticos e econômicos deste setor. Com este caráter "heterogêneo, disperso e pouco representativo" (LINHALES, 1996, p. 173) da Comissão, os interesses que acabaram prevalecendo foram aqueles da entidade que capitaneou os trabalhos desta Comissão, o CND através da figura de seu presidente, Tubino.

Instaurada pelo Decreto No 91.452 de 19 de julho de 1985, a Comissão sugeriu que o conceito de esporte fosse ampliado, "deixando a perspectiva única de desempenho e, também, compreendendo as perspectivas da educação e da participação (lazer)" (TUBINO, 2010, p. 29). Acumulando sua presidência com a do CND, Tubino ajudou a conceber a prática e a organização jurídica do esporte na perspectiva do direito, sendo que para tal propôs o reconhecimento da atividade física e do esporte como direito de todas as pessoas referenciado em documentos de cunho internacional como a Carta Internacional de Educação Física e Esporte (UNESCO, 1978 $)^{47}$. Uma das propostas originais desta Comissão era construir uma nova

http://buscatextual.cnpq.br/buscatextual/visualizacv.do?metodo=apresentar\&id=K4728286H2. Acesso: 06/11/2014.

${ }^{47}$ A Carta Internacional da Educação Física e do Esporte da UNESCO declara em seu preâmbulo que tem "o propósito de colocar o desenvolvimento da Educação Física e do esporte a serviço do progresso humano, promovendo seu desenvolvimento e instando governos, organizações não governamentais competentes, educadores, famílias e as pessoas em geral a se guiarem por ela, a disseminá-la e a colocá-la em prática". Ela instiga as nações filiadas a declararem o esporte e a atividade física, cujo principal ente promotor é a Educação Física, como direito de todos os cidadãos e cidadãs a um desenvolvimento pleno e saudável através da prática física e do esporte como elemento de educação. Ou seja, a UNESCO através deste documento compreende o esporte como direito de cada pessoa, sublinhando o vínculo deste ao desenvolvimento humano através de seu potencial educativo, elencando como sujeitos coadjuvantes neste processo as políticas desenvolvidas pelos Estados nacionais, a profissionalização e cientifização desta prática, o investimento em infraestrutura e a cooperação internacional incluindo as instituições não-governamentais e os meios de comunicação. Ressalta o papel do olimpismo neste processo: "De acordo com o ideal olímpico, o esporte competitivo, 
perspectiva do esporte com vistas a superar o viés de desempenho/performance identificado como predominante no ensino da Educação Física impingido nas políticas e legislações em vigor desde 1941.

Esse grupo trabalhou durante 120 dias (LINHALES, 1996) no intuito de que o Estado reconhecesse o esporte, sua prática e organização jurídica na perspectiva do direito. Para tal propôs o reconhecimento do esporte como direito individual de todas as pessoas assim como preconizavam os tratados internacionais utilizados em sua referência teórica. Manuel Tubino, então presidente da Comissão, do CND, professor universitário e militar da reserva, juntamente com seu grupo de discussão, referenciou-se nestes documentos e tratados internacionais para construir seu relatório, que acabou por culminar posteriormente no Manifesto Mundial de Educação Física elaborado pela instituição denominada Federação Internacional de Educação Física (FIEP), cujo próprio Tubino foi relator e primeiro presidente.

Seu trabalho na defesa da construção deste direito, ainda que aparentemente de forma a-histórica e abstrata, pois não parte dos determinantes materiais da práxis deste fenômeno para apreendê-lo, culminaram naquilo que o autor defende ser sua síntese acerca das teorias sobre a Educação Física e o esporte, a Teoria do Direito à Educação Física e ao Esporte. Esta advoga a consolidação da Educação Física no sentido de contribuir com um estilo de vida ativo para todos os seres humanos. As formas de exercício deste direito seriam esporte educacional, esporte lazer, esporte rendimento. Em decorrência deste processo surgiria o Homo Sportivus, que para o autor corresponde ao indivíduo que não abdica de exercer seu direito à Educação Física e ao esporte.

mesmo quando na forma de espetáculo, deve cumprir o propósito do esporte educacional, do qual representa o ápice. Não deve, de forma alguma, ser influenciado por interesses comerciais que visam ao lucro" (fonte: http://unesdoc.unesco.org/images/0021/002164/216489por.pdf. Acesso em 21/10/2014). No cenário mundial de extrema liberalização da economia e do trabalho iniciado na década de promulgação da carta, tal manifesto sinaliza encaminhar suas propostas pautadas pela Reestruturação Produtiva, pois aparenta sistematizar para o esporte e a Educação Física a lógica do reordenamento do trabalho e da acumulação flexível, além de mencionar explicitamente o ideário olímpico (esporte de alto rendimento) como o ápice da intervenção da Educação Física. Essa proposta no Brasil já estava em andamento pelas mãos dos governos cívico-militares através do modelo da pirâmide esportiva. 
É imprescindível acrescentar que a Teoria do Direito à Educação Física e ao Esporte não exclui as outras teorias, porque relaciona-se com o direito à participação e não aos conteúdos. Pelo contrário, esta teoria dialoga com as outras teorias e a percepção da existência do Homo Sportivus remete uma consistência à mesma. ${ }^{48}$

O autor toma para si, a partir desse movimento, a concepção de um modelo abstrato de homem, fundado em um esporte praticado nos meios educativos, nos meios populares e comunitários e o esporte de rendimento ou competição. Dessas dimensões decorrem a concepção que daria origem ao exercício desse direito representando, certamente, a síntese dos encaminhamentos do relatório da Comissão nos termos Esporte-Educação, Esporte-Lazer e Esporte de Desempenho (TUBINO, $1992)^{49}$

A respeito da prática de ensino do esporte, a conduta da Comissão Nacional de Reformulação do Esporte acabou por pasteurizar as contradições e disputas teórico-epistemológicas que estavam sendo desveladas pela cena político-acadêmica brasileira para o esporte e a Educação Física na década de 1980, contradições essas imersas em um rico e importante cenário sociocultural. Linhales (1996) afirma que não apenas no interior do Estado, mas também na sociedade civil emergiam teorias favoráveis à problematização da função social e do caráter alienante, autoritário e hierarquizado do esporte à época; esse movimento, segundo a autora, procurava desvencilhar a Educação Física e o esporte dos referenciais militares e biologicistas. Ela destaca o papel de entidades científicas e profissionais de trabalhadores em Educação Física, o Movimento dos Estudantes de Educação Física (MEEF), a imprensa com o incentivo de entidades classistas ligadas à Educação Física.

Neste caldeirão, fervilhavam no campo acadêmico discussões acerca do estatuto epistemológico da Educação Física, ganhavam repercussão as concepções críticas da Educação Física escolar, do esporte e de sua reprodução no interior da escola incentivados pela entrada das ciências humanas e sociais na área, segundo demonstrou Bracht (1999). O surgimento do Colégio Brasileiro de Ciências do Esporte

\footnotetext{
48 TUBINO, M.G. Educação Física e esporte: da teoria pedagógica ao pressuposto do direito. Disponível em http://www.cpaqv.org/metodologia/teoriasdaeducacaofisicatubino.pdf. Acesso: 02/10/2014.

49 Pires e Silveira (2007) nos auxiliarão a compreender mais adiante porque essa divisão do esporte, que os autores denominam triádica, representa uma abstração, ou seja, ideia concebida sem fundamentação histórica.
} 
(CBCE) em 1978 também influenciava de maneira protagonista a possibilidade de refletir e apontar caminhos para a Educação Física e o esporte em nosso país. Fundado, segundo Damasceno (2011), sob os auspícios do Diagnóstico da Educação Física e Esporte de 1971 e com vistas a subsidiar a ciência do esporte, ainda que na perspectiva de "neutralidade científica", acabou por se constituir, segundo Bracht (2009) um campo de lutas política justamente pela impossibilidade de neutralidade científica.

[...] o CBCE é participante do jogo pela definição do que devem ser as práticas sociais que conformam o que denominamos de cultura corporal de movimento, ao mesmo tempo em que se desdobra a luta pela definição da visão de ciência legítima no campo (ou vice-versa). Portanto, duas lutas ou disputas imbricadas: por um lado, a luta pela definição legítima de ciência (inclusive do que é ou o que configura o próprio campo) - por exemplo: ciência com seus pressupostos de objetividade e neutralidade versus ciência enquanto prática social com dimensão política e orientada por uma determinada visão de mundo, evidenciando, assim, diferentes modos de fazer e significar a prática científica -; e por outro lado, mas articulada com as diferentes visões do fazer científico, a luta por um determinado fazer Educação Física e/ou atividade física e esportiva (BRACHT, 2009, p.32/33)

E para Castellani Filho (1999) a possibilidade de um espaço onde se refletisse e produzisse uma nova forma de fazer Educação Física/esporte, constituiu-se uma peça elementar na luta para a superação de um pensamento hegemônico conservador, abrindo possibilidades para um horizonte onde se vislumbre a superação deste modo de fazer ciência alinhado às premissas que vigoravam neste campo das ciências e repercutiam na forma de ser deste bem da cultura humana.

Dentro desse quadro, ganha importância o Colégio Brasileiro de Ciências do Esporte - CBCE - como espaço vitalizador e explicitador da nossa capacidade de resistência à avalanche neoliberal que assola a sociedade brasileira em geral e nossa área em particular. (CASTELLANI FILHO, 1999, p. 158)

Todo esse movimento acabou repercutindo em diferentes setores do Estado conforme ponderou Linhales (1996), adentrando algumas Secretarias Estaduais e Municipais de Educação, assim como na Câmara dos Deputados que foi provocada através de sua Comissão de Esporte e Turismo a promover o Ciclo de Debates "Panorama do Esporte Brasileiro". A autora ressalta, entretanto, que as discussões promovidas não saíram do campo esportivo formal e do de rendimento, impossibilitando um avanço para o debate deste fenômeno às vistas do direito e de 
uma conquista social. Afirma que esta é a tônica da entrada do esporte na era da democratização dos direitos sociais:

A meu ver, é nesses termos que a abertura vislumbrada e reivindicada para o setor esportivo chega à Nova República. De um lado, várias organizações autônomas da sociedade civil demandando liberalização no esporte, e, de outro, instituições públicas e processos decisórios pouco flexíveis, não se apresentando como espaços capazes de incorporar os diferentes interesses existentes na sociedade. (LINHALES, 1996, p. 171)

A autora ressalta ainda a vanguarda do projeto de liberalização do setor levado adiante pela Comissão de Reformulação do Esporte, pois entende que não havia nenhum grupo vinculado ao setor esportivo capaz de assumir um projeto de efetiva consolidação do esporte como um direito social tendo como princípio a cidadania. O limite desta Comissão esbarrava no reconhecimento e denúncia da estrutura arcaica e autoritária do sistema esportivo brasileiro. Mesmo reconhecendo um salto qualitativo, a concepção do direito ao esporte fora fundado, segundo a autora, em possibilidades presentes apenas na letra da lei. Ela identifica algumas considerações maliciosas do relatório final, ainda que não expressas no texto encaminhado à redação final da Carta Magna de 1988, acabou por tornar-se pilar das legislações reguladoras do Artigo 217 da CF como a forma de organização do sistema esportivo e o financiamento (o qual não despreza isenções e estímulos fiscais, além da criação de um Fundo próprio):

Por certo, uma análise criteriosa das partes que compõem a Seção relativa ao desporto pode evidenciar uma ambivalência de princípios em relação à atuação do poder público no setor esportivo. Se, num primeiro momento, o texto apresenta como dever do Estado o fomento das práticas esportivas como direito de cada um, logo em seguida, prioriza a destinação de recursos públicos para o esporte educacional e, em casos específicos, para o de alto rendimento. Aqui é fundamental questionar: como se realizarão, então, as políticas esportivas voltadas para "todos" aqueles que não se encontram incluídos nem no sistema educacional nem no esporte de alto nível? A isso se soma o caráter ambíguo de expressões tais como "fomentar, "proteger" e "incentivar", que não delimitam de forma clara os necessários níveis e graus de atuação do setor público em relação ao esporte. Foram constitucionalizadas as "substâncias", mas não os "procedimentos" (LINHALES, 1996, p.181)

E conclui, sobre a construção do direito ao esporte: 
Por certo, a seção relativa ao desporto guarda coerência com o conjunto de conquistas sociais presentes na Carta de 1988 , inclusive no que diz respeito ao fato de que muitos dos avanços sociais e políticos registrados constitucionalmente, em decorrência de um grande consenso adotado como solução contemporizadora, não se encontram, ainda hoje, institucionalizados e garantidos aos cidadãos, portadores de direitos apenas "na forma da lei" (IDEM, p. 182).

Oliveira e Húngaro (2008) complementam a argumentação de Linhales quando afirmam que o acolhimento do Estado brasileiro na concessão ao sistema de proteção social na CF de 1988 respectivos a direitos sociais nos campos da educação, saúde, assistência social, previdência, trabalho, maternidade, segurança e infância foi feito em resposta a demandas populares. Mas, isso não é verdadeiro para o direito ao esporte:

Como podemos observar nos direitos acima, tanto o esporte como o lazer são assumidos pelo Estado brasileiro e, por isso, deveriam ser atendidos por meio das políticas sociais. Vale ressaltar que, diferentemente do processo que culminou na inclusão de outros direitos junto à Constituição, nem o esporte nem o lazer corresponde à reivindicações históricas da classe trabalhadora (OLIVEIRA; HÚNGARO, 2008, p. 41)

As discussões respectivas às demandas populares poderiam lograr maior sucesso em relação a democratização do esporte no âmbito da concepção deste direito, mas, segundo Castellani Filho (2013), foram secundarizadas em desfavor aos interesses dos setores que representavam o esporte de alto rendimento, os quais também representavam os setores liberais e conservadores da sociedade brasileira:

\begin{abstract}
O texto constitucional, referenciado no trabalho desenvolvido pela Comissão de Reformulação do Esporte Brasileiro (Decreto 91.452 - 19/07/85), constituída pelo então ministro da Educação da "Nova República" de José Sarney, Marco Maciel, e coordenada pelo liberal, capitão de fragata e professor Manoel José Gomes Tubino, responsável maior pelo Relatório "Uma nova política para o Desporto brasileiro: Esporte brasileiro, Questão de Estado" (1985), cedeu à pressão dos "senhores feudais do esporte" expressão do professor acima, portanto livre de qualquer desvio esquerdista - criando um precedente hoje justificador da lógica de privilegiar a exceção (recursos públicos para o esporte performance) em detrimento da regra (recursos públicos prioritariamente para o esporte educacional e de participação), ainda que, se assim não fosse, daria no mesmo, pois na lógica piramidal acima exposta, ingressando os recursos onde quer que fosse, seu destino seria o alto rendimento, situação mantida até os dias atuais. $(\text { CASTELLANI FILHO, 2013) })^{50}$
\end{abstract}

50 Disponível em: http://www.universidadedofutebol.com.br/Coluna/12304/25-anos-de-nossa-CartaMagna-e-o-esporte-brasileiro-temos-o-que-comemorar. Acesso em 15/05/2014. 
O produto desta correlação de forças entre os interesses liberais e as conquistas sociais presentes no processo constituinte foi expresso em três possibilidades: o esporte educação, esporte-rendimento e esporte-participação. Outrossim, tal como as demais conquistas sociais, a regulamentação do esporte ficou ao sabor das legislações complementares.

Starepravo (2011) afirma que neste processo houve participação da sociedade na elaboração do texto constitucional que dava luz ao esporte como direito constitucional entre eles o executivo federal representado pela Comissão de Reformulação do Esporte (cujas principais propostas foram acatadas no texto constitucional, segundo o autor), o CND, Legislativos (federal e estaduais), tribunais, entidades associativas. Entretanto, há um ator que definitivamente esteve de fora dessas deliberações. Liáo Jr (2013) citando Castellani Filho (2001) lembra que não houve participação popular na reformulação do esporte brasileiro, ou seja, houve esvaziamento de mecanismos democráticos na elaboração dessas normativas e, portanto, das suas políticas decorrentes.

Tal iniciativa representa, acima de tudo, o 'lançar mão' de uma estratégia de desmobilização da Classe Trabalhadora, antecipando-se a ela no encaminhamento de propostas de mudanças que, ao serem de iniciativa governamental, não encontram na sociedade, organização suficiente para absorvê-las e delas participar de forma efetiva.[...] Nada mais pertinente à Comissão de Reformulação do Desporto! Instituída pelo Presidente José Sarney com a incumbência - no dizer do então Ministro da Educação, Marco Maciel - de "realizar estudos e indicar soluções que, no conjunto, corporificassem uma proposta suficientemente ampla e objetiva para a promoção da necessária reformulação da política nacional para o setor", foi ela pródiga no trilhar a bastante conhecida via prussiana, angariando ao seu final resultados bastante significativos para os padrões da lógica liberal, vindo a constituir-se como referência dominante para o tratamento dado ao Esporte pela Constituição Cidadã. [...] (CASTELLANI FILHO, 2001 apud LIAO JR, 2013, p. 81)

Prevaleceram, portanto, os interesses que compreendiam a liberalização como o caminho a ser seguido, estabelecendo uma contradição aos preceitos substancialmente democráticos, como afirma Starepravo (2011). Dessa forma, pelas mãos de diversos setores e agentes ligados ao esporte, foi concebido e encaminhado o texto constitucional.

A principal contradição do texto constitucional parece ser a liberalização do esporte, ao mesmo tempo em que a tutela do Estado é mantida, especialmente através do financiamento do setor. Essa questão refletirá as políticas de esporte pós Constituição de 1988. (STAREPRAVO, 2011, p. 213) 
O ideário de um esporte moderno que superasse sua vinculação a projetos de governos voltados para o controle social e ideológico de sua população encontrava terreno fértil, clima propício e mãos habilidosas que tiveram a capacidade de semear e colher este novo produto da terra brasilis que, de acordo com essa proposta, contribuiria para a modernização econômica e social do Brasil pós-ditadura. Coube, de acordo com Starepravo (2011) ao presidente da Confederação Brasileira de Futebol de Salão Álvaro Melo Filho a redação do texto encaminhado à Assembleia Nacional Constituinte, que na forma como fora concebida, fora quase integralmente contemplada. O texto final após alguns vetos e poucas discussões no Congresso assim se apresentou:

\author{
TÍTULO VIII \\ Da Ordem social \\ CAPÍTULO III \\ DA EDUCAÇÃO, DA CULTURA E DO DESPORTO \\ Seção III \\ DO DESPORTO
}

Art. 217 - É dever do Estado fomentar práticas desportivas formais e não formais, como direito de cada um, observados:

I - a autonomia das entidades desportivas dirigentes e associações, quanto a sua organização e funcionamento;

II - a destinação de recursos públicos para a promoção prioritária do desporto educacional e, em casos específicos, para o desporto de alto rendimento;

III - o tratamento diferenciado para o desporto profissional e o não profissional;

IV - a proteção e o incentivo às manifestações desportivas de criação nacional.

$\S 1^{\circ} \mathrm{O}$ Poder Judiciário só admitirá ações relativas à disciplina e às competições desportivas após esgotarem-se as instâncias da justiça desportiva, regulada em lei.

$\S 2^{\circ} \mathrm{A}$ justiça desportiva terá o prazo máximo de sessenta dias, contados da instauração do processo, para proferir decisão final.

$\S 3^{\circ} \mathrm{O}$ poder público incentivará o lazer, como forma de promoção social. (BRASIL, 1988)

As disputas travadas no âmbito da Assembleia Nacional Constituinte permitiram, à sombra da Contra-Reforma do Estado brasileiro, que o esporte ganhasse sua "carta de alforria" do controle ideológico do Estado e a constituição de seu caráter privado. Mas, ainda assim, ganhava também uma "carta de crédito" para que este fosse seu ente mantenedor e financiador, à luz do estado democrático de direito. A divisão desta manifestação da cultura humana em duas possibilidades fundamentais e diferenciadas - desporto educacional e desporto de alto rendimento - 
deu margem às legislações reguladoras para desdobrarem e reforçar esta iniciativa contumaz de liberalização e consequente distanciamento das possibilidades emancipatórias desta manifestação da cultura humana.

Manhães (2002) reitera que garantida a liberdade de organização, caberia às legislações infraconstitucionais regulamentarem o modo como deve ser o usufruto desta autonomia, dando destaque para o tratamento diferenciado explicitamente anunciado no texto constitucional ao desporto profissional e o não profissional, com ênfase ao desporto educacional. E deixa claro que essa liberalização implícita no texto constitucional concedeu a abertura que os setores hegemônicos e conservadores precisavam:

Com o passar dos anos, a ordem corporativa deu lugar a uma oligarquia desportiva que se confunde com as elites partidárias e políticas conservadoras, constituindo-se no bloco social que resiste às modernizações que apontem para o fim do estado patrimonialista, fonte privilegiada de recursos ilegítimos e de instrumentos de controle que reproduzem as relações de poder tradicionais. Esse cenário é o contexto determinante da formação de um mundo desportivo em que a ética e o discurso político são instrumentos de ocultação de interesses menores e particulares inconfessáveis. (MANHÃES, 2002, p. 110)

Doravante, cabe destaque à manifestação compreendida no texto constitucional de desporto escolar, pois este conceito nos remete frontalmente ao objeto desta pesquisa e, portanto, seu surgimento enquanto categoria de análise é passível de uma aproximação mais íntima. Esse movimento se dará no próximo Ato. 


\section{$4^{\circ}$ Ato - Políticas do esporte educacional: sua história e concepção ${ }^{51}$.}

No bojo das mudanças sociais e econômicas que consolidaram o projeto neoliberal como estratégia do reordenamento produtivo da sociedade brasileira também se encontrava a concepção e materialização do esporte como direito de cada cidadão brasileiro. O surgimento da categoria esporte educacional, sua consolidação como direito constitucional e, consequentemente, as legislações infraconstitucionais e políticas ensejadas em decorrência disso certamente respondem ao movimento de reordenamento do capital e Contra-Reforma do Estado a partir da compreensão da prática do esporte de forma fragmentária segundo ponderam Pires e Silveira (2007).

Para os autores existem dois eixos, ou teses centrais, que permeiam a construção e o desenvolvimento desta subdivisão categorial e que concernem especificamente ao esporte educacional. A primeira delas é que não existe um esporte educacional em si, o que existe é uma situação dual: aquele que visa o rendimento e aquele que é praticado no tempo livre. Nos ambientes educativos há uma constante tensão entre essas duas perspectivas, tendo em vista que o esporte praticado nas instituições educativas se inclina de acordo com as situações que englobam o contexto onde está inserido, para uma ou outra perspectiva:

\footnotetext{
${ }^{51}$ É fundamental destacar que o termo esporte educacional é adotado neste trabalho não apenas para enquadrar seu objeto, mas também todos os ordenamentos legais e dispositivos políticos que se referenciem a esta demarcação categorial. Na dubiedade do uso das expressões desporto ou esporte, recorreremos à interpretação de Castellani Filho (2007) que afirma ser o termo desporto usualmente adotado para enquadrar de forma normativo-legislativa este fenômeno. Dando sentido à expressão esporte como um termo brasileiro para se referir a este patrimônio cultural da humanidade, o autor cita o professor Gaudêncio Frigotto quando este diz que os conceitos são "representações no plano do pensamento do movimento da realidade" (FRIGOTTO apud CASTELANNI FILHO, op. cit), e como tal, não são "alheios às relações de poder e às relações de classe presentes na sociedade. Pelo contrário, são as mediações de suas explicitações ou de seu mascaramento" (ibid.). Portanto, o uso do conceito esporte dá sentido não somente a uma expressão que segundo Castellani Filho (op. cit.) representa uma espécie de "desburocratização" do uso deste termo, assim como a adesão de setores populares, acadêmicos - como o Colégio Brasileiro de Ciências do Esporte (CBCE) - e movimentos sociais ao sentido lúdico que carrega. (CASTELLANI FILHO, L. Sobre o Desporto... ou seria Esporte? Disponível em http://cev.org.br/biblioteca/notas-para-uma-agenda-esporte-brasileiro/. Acesso : 04/11/2014). Não obstante, a adesão a este conceito também se justifica por entendermos que a subdivisão da prática do esporte cunhada por sua legislação representa uma abstração da manifestação deste fenômeno social (PIRES; SILVEIRA, 2007) e uma demarcação categorial adotada pelas legislações reguladoras do texto constitucional.
} 
Neste embate, configura-se um conjunto de situações que envolve e, de certo modo, dá conformidade ao esporte, do cenário sociocultural em que acontecem essas práticas esportivas (escolas, universidades, instituições socioeducativas etc.) até as representações e valorações dos vários agentes sociais que propõe e implementam o esporte no ambiente educativo. Valores estes que podem ser identificados nos documentos orientadores oficiais do esporte, nas demandas sócio-político-econômicas que levam à proposição e implementação de políticas públicas, na formação profissional do educador e na sua visão de mundo, sociedade, ser humano, educação, esporte, entre outros. (PIRES; SILVEIRA, 2007, p. 25)

Os autores argumentam que a divisão do esporte em três manifestações conforme estipula nossa legislação - esporte rendimento, educação e participação é um produção abstrata, respaldando-se em Bracht (1997, apud PIRES e SILVEIRA, 2007) que o considera dual: ora ele se manifesta como rendimento [digo, portanto, profissão ou negócio] ou meramente uma prática no tempo livre. Essas possibilidades se transpõem quando se tornam um produto a ser consumido no tempo livre, sendo que na escola há um constante tensionamento entre essas concepções, ora deslocando-se para um ou para outro, e sua reconstrução (ou podemos dizer pedagogização) é aquele praticado por dentro dos muros da escola.

A segunda tese diz que toda manifestação esportiva é educativa, seja de forma intencional (explícita) ou não. O esporte em si carrega um arcabouço de valores, aptidões, conceitos e condutas que se reproduzem tanto em sua prática formal quanto informal, como lazer (praticado ou consumido) ou educação. Esses valores também estão consubstanciados aos interesses, valores, objetivos e conhecimentos entre os agentes deste processo não havendo, portanto, neutralidade. Considerando essas teses, podemos apreender a intencional vantagem que o esporte reconhecido como de rendimento apresenta em relação às demais manifestações concebidas a partir de sua constitucionalização:

Assim, podemos sugerir, como Paulo Freire (1970), que também no esporte escolar não existe uma prática pedagógica que se constitua como neutra: ou se educa para a libertação e fruição autônoma desta manifestação da cultura de movimento ou com certeza se estará educando para a domesticação e a reprodução acrítica de valores, práticas, entendimentos a respeito do esporte. (PIRES; SILVEIRA, 2007, p. 25/26)

A forma como essa manifestação da cultura corporal foi concebida no texto das deliberações da Comissão de Reformulação do Esporte, ratificada na CF, ao que parece, aproxima-se do conceito de práxis utilitária de Kosik (1976), a qual não 
proporciona a compreensão plena das coisas e da realidade, posto fundar-se na divisão do trabalho, da sociedade de classes e na hierarquização social e, dessa forma, representar tão somente um fenômeno superficial em relação à essência do contexto social. Ou seja, a reificação desta manifestação não permitiu que se avançasse para além do que ele aparentava no momento de sua materialização como direito.

A abstração desta subdivisão triádica assinalada por Pires e Silveira (2007) parece caminhar ao encontro desta concepção de Kosik (1976), pois este assevera que a compreensão da humanidade sobre diversas manifestações de sua cultura e de suas teorias como a ciência, política, arte, esporte, etc., representadas em sua práxis cotidiana, as formas reificadas parecem ganhar hegemonia. Dessa forma, sua idealização manifesta-se através daquilo que Kosik conceitua práxis utilitária. Isso pode representar uma impossibilidade de reconhecer seu processo histórico de concepção, elaboração e implantação, transformando-a "coisa em si” e, assim, mantendo-a no mundo da superficialidade, dos fenômenos. No momento que se sobrepõe partes do todo material como elementos principais da análise de um cenário político, ou das políticas em si, corre-se o risco de imergir-se na práxis utilitária, fetichizada, que é útil principalmente para a reprodução social da ordem vigente.

O autor assinala a necessidade de um esforço sistemático para a superação da práxis utilitária, através do pensamento crítico não-reducionista, com vistas a alcançar a essência do fenômeno, ou seja, transcender a sua aparência - a pseudoconcreticidade - para que se alcance o "mundo real", o "mundo da práxis humana" (KOSIK, 1976). Nele, o homem encontra a possibilidade de humanizar-se, revelando-se sujeito do mundo real, onde a práxis humana, para KOSIK (1976), afirma-se como processo revolucionário da superação da pseudoconcreticidade.

Retomando o raciocínio de Pires e Silveira, estes descrevem a trajetória do esporte educacional no Brasil desde a época da ditadura militar até o primeiro governo Lula, apontando o aparecimento do Ministério do Esporte (ME) como um marco político fundamental no sentido de consolidá-lo em sua concepção e propostas originais, aquelas concebidas desde os governos da ditadura civil-militar.

A argumentação dos autores tem como ponto de partida o início da década de 1980, como vimos, época na qual o esporte era tido como estratégia de controle social e propaganda nacionalista-ufanista a favor do regime. Pires e Silveira (2007) 
destacam sua utilização nas escolas como uma propaganda positiva para o regime através de ações como o programa Esporte Para Todos (EPT), a valorização dos Jogos Escolares Brasileiros (JEB's) e dos Jogos Universitários Brasileiros (JUB's), com amplo respaldo de setores da sociedade como o econômico-financeiro e a mídia.

Com o advento de uma corrente que criticava esse uso estatal/ideológico do esporte, pois o identificava como instrumento de legitimação da ordem social burguesa favorável à propaganda do governo militar, Pires e Silveira (2007) perceberam a ressonância social dessas concepções críticas sobre o esporte como contraponto à essa forma hegemônica de reprodução do esporte nas práticas educativas. Entretanto, relatam a falta de avanços conceituais e propositivos na prática do esporte na escola decorrentes desse movimento, já que este negava o caráter de rendimento e performance que se reproduzia nos contextos escolares através da Educação Física escolar e, através de sua negação radical houve, segundo os autores, um período chamado por eles de laissez-faire do esporte na escola - à Educação Física escolar bastava entregar a "bolinha" na hora da aula que já estaria cumprindo seu papel contra-hegemônico.

Destarte, a reformulação da política nacional de esporte, que conforme vimos foi oficialmente conduzida pela Comissão de Reformulação do Esporte Brasileiro sinalizou uma co-responsabilidade da União, Estados e Municípios pelo incentivo, promoção e manutenção do esporte educacional, buscando transferir o esporte de rendimento para a iniciativa privada. Mas, os autores demonstram que essa iniciativa nunca chegou a acontecer, ao contrário, veio fortalecer-se o vínculo esporte-Estado através de diversas iniciativas de financiamento (a exemplo da Lei Agnelo-Piva e de patrocínios diversos de empresas estatais ao esporte de alto rendimento) e iniciativas dos entes federativos para financiar o esporte educacional na perspectiva da detecção de talentos. Tais iniciativas foram identificadas por eles em pesquisas que abrangem políticas de esporte educacional desde o processo de redemocratização até o primeiro mandato do governo Lula e expressam, segundo os autores, a valorização da perspectiva funcionalista desta manifestação da cultura humana.

É importante destacar através do percurso realizado até aqui que esta subdivisão, chamada por Pires e Silveira (2007) de triádica é o produto do trabalho de uma Comissão composta por atores de interesses dubitavelmente democráticos, mas notoriamente sectários aos interesses privatistas e liberais. Isso levanta dois pontos 
chaves de discussão: o primeiro, que não há uma perspectiva educativaemancipatória embutida nesta demarcação categorial, triádica a partir das discussões e deliberações da Comissão de Reformulação do esporte Brasileiro, mas dicotômicas no texto da CF (esporte-rendimento em detrimento do esporte-educação). O segundo é que, de maneira institucional e renovada, os setores conservadores ligados a política esportiva embutem de forma sagaz no âmbito da legislação maior do Estado sua perspectiva liberal, a qual inclui tanto a ampliação do seu mercado consumidor (dado a dualidade apontada pelos autores supracitados) como a base de seu mercado de trabalho (ao reforçar a lógica da pirâmide esportiva).

Tendemos a concordar com Pires e Silveira (2007) no sentido que sempre há um conjunto de valores, aptidões, conhecimentos ou condutas transmitidas pelo esporte, e que o aprendizado decorrente desta prática é resultado de uma série de fatores que incluem a formação cultural e profissional dos atores que lidam com o esporte em âmbito educativo, os interesses e a atmosfera social que permeia essa intervenção, da disputa por hegemonia entre os atores envolvidos, desde a concepção, elaboração e execução de políticas para o setor como sua própria relação com a cultura esportiva. Nesse sentido é suposto, a partir da análise dos autores acima citados que o percurso histórico do esporte educacional se reveste de intencionalidades voltadas ao interesse do sistema político e social na perspectiva de reprodução das classes hegemonicamente dirigentes, com vieses econômicoreprodutivistas, posto a escola e o esporte educacional inclinarem-se, segundo esse modelo de políticas para o setor, à base do esporte de rendimento. Sob essas circunstâncias concebe-se e reproduz-se o direito ao esporte no Brasil através de suas legislações e política.

Sua subdivisão nos termos da lei (apresentando-se sob essas três manifestações) respalda, pari passu, o direcionamento das legislações infraconstitucionais e Políticas voltadas para garantia deste direito, claramente fundados em premissas de desenvolvimento de caráter liberalizante, prezando a livre iniciativa jurídico-institucional e econômica do setor ao modo neoliberal, contudo com subvenções do Estado e voltado para garantia de suas ideias conservadoras.

A partir de sua constitucionalização, legislações infraconstitucionais foram criadas de forma a regular especificamente o esporte dentro dessas novas possibilidades. Destacam-se duas delas: a primeira delas a Lei $N^{\circ} 8.672$ de 
06/07/1993, a Lei Zico, visava sua modernização, ainda que conservadora-liberal (VERONEZ, 2005), dando prioridade para questões como a profissionalização de atletas, entidades esportivas, questões normativas, jurídicas e de financiamento. Segundo o autor, a lei trilhou o mesmo caminho dos demais projetos de modernização do país à época (governo Collor de Melo), conciliando interesses que representavam o "conservadorismo e o atraso" (p. 299). A lei estabeleceu autonomia e independência ao setor esportivo livre de qualquer controle social ao implementar a desresponsabilização do Estado para com ele, assegurando às entidades esportivas (Federações, Confederações, clubes e associações) o status de "pessoa jurídica de direito privado" (IDEM). Em relação ao preceito constitucional de priorizar o desporto educacional em detrimento das demais manifestações, tornou-se claro a intenção falaciosa desta Lei, segundo Veronez:

\begin{abstract}
Embora na introdução do documento que apresenta a nova lei à sociedade seja explicitado que as "palavras-chave" desta são educação, participação e rendimento, tudo o que vem a seguir reporta-se exclusivamente aos interesses daquelas entidades privadas. Não há uma frase sequer que se refira à questão social no âmbito esportivo e, em especial, nas manifestações do esporte educacional (prioridade prevista na CF de 1988) e do esporte de participação. (VERONEZ, 2005, p. 301)
\end{abstract}

Já a segunda, a Lei Pelé (Lei n 9.615 de 24 de março de 1998), segundo Castellani Filho (2008) manteve em sua essência o texto da lei anterior, entretanto, demarcando um espaço fundamental para o esporte, o do financiamento público. Dessa forma, o Estado consolida sua presença no âmbito do financiamento do esporte, mas de forma a assegurar os interesses privados regidos pela lei do mercado e da "livre iniciativa":

Uma lei que, em verdade, modifica minimamente a "Lei Zico" - poderia ter sido simplesmente entendida como um conjunto de pequenas alterações da "Lei Zico", mas havia a necessidade de ter a chancela do Pelé (o DNA do Pelé) numa nova lei; numa nova configuração de uma lei esportiva brasileira; que reforça a lógica de um Estado financiador da política esportiva centrada nas entidades esportivas com personalidades jurídicas de direito privado. Esse novo conjunto ganha vida e prevalece até início do século XXI. (CASTELLANI FILHO, 2008, p. 137)

Podemos observar que se encontram claramente expressas na Lei Pelé as concepções da Comissão de Reformulação do Esporte. Seu texto dá um salto no que diz respeito ao direito dos atletas (sua profissionalização) e regulação das entidades 
que cuidam do esporte em suas práticas sociais, profissionais e jurídicas e nas normatizações respectivas à questão do esporte. Não avança, entretanto, na afirmação do direito àquilo que é denominado esporte educacional, apenas assegura sua presença dentre as possibilidades de manifestação do esporte sem que haja propostas, diretrizes ou regulamentações sobre essa categoria:

\begin{abstract}
Art. $3 \circ \mathrm{O}$ desporto pode ser reconhecido em qualquer das seguintes manifestações:

I - desporto educacional, praticado nos sistemas de ensino e em formas assistemáticas de educação, evitando-se a seletividade, a hipercompetitividade de seus praticantes, com a finalidade de alcançar o desenvolvimento integral do indivíduo e a sua formação para o exercício da cidadania e a prática do lazer;

II - desporto de participação, de modo voluntário, compreendendo as modalidades desportivas praticadas com a finalidade de contribuir para a integração dos praticantes na plenitude da vida social, na promoção da saúde e educação e na preservação do meio ambiente;

III - desporto de rendimento, praticado segundo normas gerais desta Lei e regras de prática desportiva, nacionais e internacionais, com a finalidade de obter resultados e integrar pessoas e comunidades do País e estas com as de outras nações. (BRASIL, Lei nº 9.615 de 1998).
\end{abstract}

Quinze anos após a promulgação da Lei Pelé, em 2013, ocorre sua segunda regulamentação através do Decreto $N^{0} 7.984$ de $08 / 04 / 13^{52}$, o qual dá outro salto em relação ao texto da lei ao dar maior clareza e delineamento às ditas possibilidades de manifestações do esporte (educacional, participação ou rendimento), demarcando o desporto educacional como uma manifestação atrelada a práticas esportivas no interior da escola, com o caráter de alcançar o desenvolvimento educativo do sujeito:

Art. $3^{\circ} \mathrm{O}$ desporto pode ser reconhecido nas seguintes manifestações:

I - desporto educacional ou esporte-educação, praticado na educação básica e superior e em formas assistemáticas de educação, evitando-se a seletividade, a competitividade excessiva de seus praticantes, com a finalidade de alcançar o desenvolvimento integral do indivíduo e a sua formação para o exercício da cidadania e a prática do lazer;

II - desporto de participação, praticado de modo voluntário, caracterizado pela liberdade lúdica, com a finalidade de contribuir para a integração dos

52 A primeira deu-se através do Decreto Nº 2.574 de 29/04/1998. 
praticantes na plenitude da vida social, a promoção da saúde e da educação, e a preservação do meio ambiente; e

III - desporto de rendimento, praticado segundo as disposições da Lei no 9.615, de 1998, e das regras de prática desportiva, nacionais e internacionais, com a finalidade de obter resultados de superação ou de performance relacionados aos esportes e de integrar pessoas e comunidades do País e de outras nações.

\section{$\S 1^{\circ} \mathrm{O}$ desporto educacional pode constituir-se em:}

I - esporte educacional, ou esporte formação, com atividades em estabelecimentos escolares e não escolares, referenciado em princípios socioeducativos como inclusão, participação, cooperação, promoção à saúde, co-educação e responsabilidade; e

II - esporte escolar, praticado pelos estudantes com talento esportivo no ambiente escolar, visando à formação cidadã, referenciado nos princípios do desenvolvimento esportivo e do desenvolvimento do espírito esportivo, podendo contribuir para ampliar as potencialidades para a prática do esporte de rendimento e promoção da saúde. (BRASIL, 2013).

$\S 2$ O O esporte escolar pode ser praticado em competições, eventos, programas de formação, treinamento, complementação educacional, integração cívica e cidadã, realizados por:

I - Confederação Brasileira de Desporto Escolar - CBDE, Confederação Brasileira de Desporto Universitário - CBDU, ou entidades vinculadas, e instituições públicas ou privadas que desenvolvem programas educacionais; e

II - instituições de educação de qualquer nível.

Sobre essa nova regulamentação Seron (2013) entende que as mudanças não foram relevantes ao ponto de garantir mudanças substanciais na organização "espiritual" desta manifestação do esporte, pois apesar de sua ramificação estipulada pelo Decreto, pareceu que ambas possibilidades são complementares: "Parece haver um ciclo esportivo voltado para o esporte performance nesta ideia: primeiro identificam-se talentos, para posteriormente ampliar-se as possibilidades visando o esporte de rendimento" (SERON, 2013, p. 36).

A autora destaca ainda o amplo aparato regulamentado como entidades afetas à organização do esporte escolar: Confederações (CBDE, CBDU, COB, CPB, CBC), entidades privadas (COB, CPB, SESC, SENAI), além do próprio aparato institucional (ME, CNE e Sistemas Brasileiro, Nacional, Estaduais e Distrital de Esporte) envolvidos no fomento, organização, planejamento e controle das ações envolvidas nesta manifestação. Ela enfatiza que a principal atuação destes agentes diz respeito à 
organização de eventos e competições escolares (50\% dos recursos totais, estes provenientes de diferentes fontes). Ou seja, não foi identificado neste estudo investimentos que garantam o preceitos normativos pautados pelo princípios socioeducativos da inclusão, participação, cooperação, promoção à saúde, coeducação e responsabilidade, ou ainda ações intencionais e propositivas que evitem a seletividade, a competitividade excessiva de seus praticantes.

Diante destas condições, a autora conclui que o esporte educacional, segundo a legislação em questão, representa a própria normatização da pirâmide esportiva.

\begin{abstract}
A regulamentação da Lei Pelé parece representar a regularização das competições estudantis, uma vez que sempre estiveram presentes com exclusividade nas ações políticas de desporto escolar. Dessa forma, a promulgação do Decreto 7.984/2013 reforça de forma habilidosa o esporteespetáculo no contexto estudantil, colocando em segundo plano os aspectos educacionais inerentes à formação dos indivíduos, que se beneficiam dessa ação política. (SERON, 2013, p. 43)
\end{abstract}

Se partirmos da assertiva marxiana de que "a anatomia do homem dá-nos uma chave para compreender a anatomia do macaco" (MARX, Introdução à Crítica da Economia Política) ${ }^{53}$, podemos depreender que a legislação "mais avançada" sobre esporte educacional, o Decreto $N^{\circ} 7.984 / 2013$, pode nos auxiliar a compreender a lógica existente em suas políticas desde o marco de sua institucionalização, a sua subdivisão triádica e abstrata, conforme sinalizam Pires e Silveira (2007), em especial ao trato dispensado desde então ao desporto educacional, hoje subcategorizado em esporte educacional e esporte escolar. Ao final deste Ato, se descerrem a maquiagem e os figurinos de seus atores e cenários.

53 Expressão cunhada por Marx para relatar que as categorias presentes nas relações da sociedade capitalista e sua forma de produção são tão complexas e desenvolvidas que dão os indícios para compreender as demais formas de produção das sociedades pregressas. Disponível em http://www.histedbr.fe.unicamp.br/acer fontes/acer marx/tme 15.pdf. Acesso: 04/11/2014 


\section{Ato Final - Descortinando o direito ao esporte}

Acredito ser importante a compreensão deste processo histórico sob a luz do pensamento de Gramsci. A construção do direito ao esporte e a forma como ele se materializou através de políticas públicas revelam e reproduzem uma guerra de posições que deslocou o pensamento hegemônico do Estado em sentido estrito para a Sociedade Civil através da liberalização, abrangendo esses entes na perspectiva gramsciniana (COUTINHO, 2011).

Para Gramsci (apud COUTINHO, 2011) o Estado é compreendido como a correlação entre organismos políticos que compreendem a sociedade política e a sociedade civil. A primeira, onde se encontra o governo (também por ele denominado Estado em sentido estrito) é quem detém a hegemonia da sociedade - direção, controle, regulação, aparelho coercitivo. Ou seja, os atores da sociedade política se encontram em posição privilegiada para dar direção à sociedade e fazer prevalecer seus interesses intelectuais e morais. Ou, nas palavras de Gramsci, exercer sua hegemonia:

[...] a supremacia de um grupo social se manifesta de dois modos, como "domínio" e como "direção intelectual e moral". Um grupo domina os grupos adversários, que visa "liquidar" ou a submeter inclusive com a força armada, e dirige os grupos afins e aliados. Um grupo social pode e, aliás, deve ser dirigente já antes de conquistar o poder governamental (esta é uma das condições principais para a própria conquista do poder); depois, quando exerce o poder e mesmo se o mantém fortemente nas mãos, torna-se dominante mas deve continuar a ser também "dirigente" (GRAMSCI, 2004 apud COUTINHO, 2011, p. 290)

Já a sociedade civil para Gramsci é o "aparelho privado de hegemonia", ou ainda as organizações ditas privadas como a igreja, os sindicatos, ou as escolas que não somente exercem a função de educar segundo os preceitos da classe dominante, mas segundo Gramsci "para este fim, tende uma multiplicidade de outras iniciativas e atividades chamadas privadas, que formam o aparelho da hegemonia política e cultural das classes dominantes (apud COUTINHO, 2011). É o local onde operam os "intelectuais orgânicos", indivíduos ligados a determinados grupos sociais que dão homogeneidade ao pensamento deste grupo, constituído sua vanguarda intelectual e cultural. Na sociedade contemporânea, esta sociedade civil agrega outros entes como o setor financeiro, e as organizações privadas. Dentre elas os setores 
esportivos que, conforme temos visto, adquiriram autonomia em relação ao governo - no caso do esporte, as federações, confederações e o COB por exemplo.

Nesse raciocínio, Montaño (2010) nos mostra que a sociedade civil de nossa contemporaneidade se constitui em uma arena de lutas que é altamente porosa a interesses de frações de classe que representam a lógica da acumulação de capital e desconstituição de direitos sociais. Essa atitude respalda o movimento de Reestruturação rodutiva e Contra-Reforma que reafirmam os interesses da classe hegemônica cultural e economicamente, esvaziando as possibilidades emancipatórias e de ampliação de direitos da classe trabalhadora:

\begin{abstract}
Dessa forma, as lutas desenvolvidas na sociedade civil, e particularmente na sua cotidianidade, são absolutamente necessárias num processo de efetiva transformação social, a caminho a emancipação humana. [...] uma sociedade com uma "primitiva" e "gelatinosa" sociedade civil compromete fortemente o processo de transformação societária, o que decerto confirma a afirmação marxiana sobre a maior possibilidade de revolução no pólo mais desenvolvido do sistema capitalista. (MONTAÑO, 2010, p. 264)
\end{abstract}

Os interesses ligados ao campo esportivo organizado, esses vinculados ao esporte de alto rendimento e seus representantes (atletas, dirigentes e o setor econômico vinculado ao esporte) exerceram sua hegemonia em relação às políticas de esporte no Brasil. Isso apresenta-se de forma lógica no ordenamento legal que organiza esse campo em nosso país. Os interesses populares que apontam no sentido da plena garantia de seus direitos, que segundo Húngaro (2008) é uma das etapas da emancipação política no caminho para a emancipação humana, não parecem estar contemplados neste ordenamento legal, o qual é o pilar para a concepção de políticas públicas. Para Marx (apud Texter in Húngaro, 2008)

A emancipação política é, sem dúvida, um grande progresso; mas certamente não é a fórmula final da emancipação humana em geral, e sim a fórmula final da emancipação humana no interior da ordem do mundo que existiu até aqui. Bem entendido, falamos de uma emancipação real, prática. (HÚNGARO, 2008, p. 176)

Neste debate sobre emancipação Húngaro (2008) explica que na concepção marxiana a emancipação humana transcende a emancipação política sendo, pois, revolucionária, já que assim permite ao homem superar sua condição de alienação imposta pelo modelo social capitalista. E esta revolução a que Marx se refere é uma 
tarefa, segundo o Húgaro (2008), que possui como protagonista a classe proletária, dado que a centralidade da vida social para Marx é o trabalho. E nessa forma de organização da vida social a classe proletária é a que se encontra submissa às funções produtivas da divisão social do trabalho. Mas Húngaro destaca que esta possibilidade revolucionária somente poderá ser esboçada através da ascensão da classe em si para classe para si através da passagem dos interesses individuais para os coletivos. Isso supõe a superação das relações sociais de produção burguesa ${ }^{54}$. No entanto, o autor destaca que não há uma receita universal para esta revolução, que se encontra condicionada às circunstâncias, limites e possibilidades dos "sujeitos históricos revolucionários" envolvidos no processo.

Nesse sentido, o sujeito histórico revolucionário indicado por Húngaro (2008) parece surgir neste processo de construção do direito ao esporte como "sujeito oculto", ou ainda "sujeito indeterminado", dado que os interesses em evidência nas legislações e políticas de esporte não aparentam guardar relações com aqueles da classe trabalhadora/proletária, desagregando os interesses revolucionários desta classe no que tange à sua emancipação política (a conquista de direitos) em direção à sua emancipação humana que para Marx, que apenas ocorrerá com o fim do "trabalho alienado e suas formas de divisão na ordem burguesa" (apud HÚNGARO, 2008, p. 177).

Ao percebermos a concepção do direito ao esporte no Brasil, seus atores, além do contexto político e socioeconômico podemos depreender que a dinâmica de seu desenvolvimento histórico se inclina à concepção de políticas públicas que deem respaldo aos interesses da classe hegemonicamente predominante no sistema capitalista.

E voltando esta análise no sentido da concepção de políticas públicas que contemplem o esporte como bem social é importante recorrer ao conceito de Pereira (2008), que afirma ser a política pública uma "ação pública, na qual, além do Estado, a sociedade se faz presente, ganhando representatividade, poder de decisão e condições de exercer o controle sobre sua própria reprodução e sobre os atos de

\footnotetext{
${ }^{54}$ Para Marx o momento ontológico primário é o trabalho, que representa relação do homem com a natureza, onde ele a transforma diante de suas reais necessidades criativas e livres para sua realização enquanto ser genérico. Contudo, nas relações estabelecidas pelo modo de produção da burguesia no qual o homem é subsumido ao outro através das classes sociais, este é desumanizado, pois seu trabalho não lhe pertence, mas sim ao capitalista (HÚNGARO, 2008).
} 
decisões de governo" (PEREIRA, 2008a, p.94). Para a autora, essa relação dialética entre Estado e sociedade apresenta quatro características fundamentais:

1-) é um marco para orientar uma ação pública, a qual é de responsabilidade a autoridade pública e controlada pela sociedade;

2)- visa concretizar direitos sociais conquistados pela sociedade e expresso nas leis, operacionalizando-se via programas, projetos ou leis;

3-) deve guiar-se pelo interesse comum, público, ou seja, de todos;

4-) não deve atender aos interesses econômico-privados, mas sim a satisfação das necessidades sociais.

A política pública requer intervenções tanto do Estado quanto da sociedade, é uma ação pública, sob responsabilidade do ente público, sob o controle da sociedade. Visa materializar direitos conquistados pela sociedade através de programas, projetos e serviços, devendo atender ao interesse comum, ou público, tendo em seu horizonte as necessidades sociais e não do capital. A autora assevera que o governo é o protagonista fundamental na criação e processamento das políticas públicas as quais devem se guiar pelos direitos sociais (perspectiva de equidade e justiça social), embora tenham em seu horizonte os direitos individuais (se guiam pelo princípio da liberdade). Este direito, como é o caso do direito ao esporte, concebe os cidadãos como sujeitos genéricos, abstratos, sem especificidades.

Já os direitos sociais (que combinam liberdade com igualdade), segundo Pisón (1998 apud PEREIRA, 2008a) decorrem dos direitos políticos (liberdade política), que decorre dos direitos civis (liberdade individual) e dão origem aos direitos difusos (internacionalização dos direitos individuais como paz, autodeterminação dos povos, meio ambiente, patrimônio cultural da humanidade).

Por essa forma, ao aproximar esse conceito do nosso objeto de pesquisa, o Centro de Iniciação Desportiva (CID), e percebendo este Projeto como uma política que oferta a estudantes da rede pública de ensino a possibilidade de praticar quase duas dezenas de modalidades esportivas de forma gratuita e para diversas idades, é possível afirmar que ele configura-se em uma iniciativa da autoridade pública (o Estado) em forma de política pública que intenciona o acesso a um direito expresso na Constituição Federal. Esta política visa conferir contornos educativos à manifestação do fenômeno social esporte, supostamente buscando garantir o acesso 
a este direito através, e especialmente neste caso, da manifestação compreendida como esporte educacional.

No coletivo das políticas de esporte no Distrito Federal, o CID se apresenta como uma possibilidade de esporte educacional, sendo organizado e mantido pela Secretaria de Educação do Distrito Federal. No próximo capítulo será realizada uma aproximação maior ao Projeto CID para compreender como ele é concebido, se organiza e materializa no contexto das demais políticas esportivas do DF, tomandose como referência o Plano Plurianual do Governo do Distrito Federal. E, inserindo-o nestas políticas, procuraremos compreender como o Projeto CID responde, em sua experiência atual, às questões levantadas e debatidas até o momento. 


\title{
Capítulo 3 - As políticas de Esporte do Distrito Federal e o Projeto Centro de Iniciação Desportiva
}

\begin{abstract}
A garantia dos direitos à prática e à fruição do esporte e do lazer, deve ser materializada pela perspectiva emancipatória, não por eventos nem por abstrações mistificadoras, tais como "inclusão social", "ferramenta para a paz", "educação para a cidadania", "qualidade de vida", "desenvolvimento humano", tampouco por este pretenso, difuso e controverso "Legado Social", astutamente agregado à justificativa social dos Megaeventos. (LIÁO JR., 2013, p. 86)
\end{abstract}

Neste Capítulo situaremos o Projeto CID nas políticas esportivas do Distrito Federal. A princípio, foi feito um esboço do desenho institucional das políticas esportivas no DF, tomando como referência os Planos Plurianuais de 2008-2011 e 2012-2015. Esse referencial, que se constitui o marco temporal de análise desta pesquisa, revela a história recente de mais de 30 anos de existência do CID (QUIRINO, 2012), ou seja, uma política que atravessou os anos da ditadura cívicomilitar, cujo referencial de esporte educacional era ditado pelo Diagnóstico da Educação Física e Esportes - a constitucionalização, regulação, liberalização e hoje encontra-se no contexto da chamada década esportiva em nosso país, segundo Bracht e Almeida (2013) e Guirra (2014) iniciada com os Jogos Panamericanos Rio 2007 e perpassando os Megaeventos Jogos Mundiais Militares Rio 2011, Copa das Confederações e Gymnasíade em 2013, Copa do Mundo FIFA 2014 e Olimpíadas e Paralimpíadas Rio 2016.

Tomaremos contato com o desenho institucional das políticas esportivas previstas nos dois últimos PPAs do DF. Situando o esporte educacional neste quadro, discutiremos sua presença nesses Planos de ação política do Governo do Distrito Federal (GDF) para com o esporte, tomando como referência para análise a lógica que estas políticas engendram e os referenciais que a embasam.

A seguir, é feita uma aproximação pontual ao Projeto CID, este já situado nas políticas previstas no mais recente PPA, ao contrário do anterior. Reconheceremos 
seu marco político institucional/normativo e seu marco conceitual que enriquecidos por aproximações à sua materialidade nos ajudarão a analisa-lo no capítulo seguinte.

\section{As políticas esportivas no Distrito Federal}

As políticas de esporte desenvolvidas no Distrito Federal analisadas por esta pesquisa têm como fonte os dois últimos Planos Plurianuais. O Plano Plurianual (PPA) é um instrumento de planejamento das ações do Estado previsto na Constituição Federal em seu artigo 165 e no Distrito Federal pelo Art. 149 da Lei Orgânica do Distrito Federal. Sua elaboração tem como horizonte o desenvolvimento social e econômico do DF e representa o planejamento do governo para as ações do Estado no período de 4 anos.

Segundo Garcia (2015), o caráter evidente de coordenador das despesas governamentais tem sido a marca dos PPAs desde que este fora concebido pelos constituintes de 1987. O viés assumido de uma programação plurianual de despesas, teve nas disputas políticas entre o projeto neoliberal em curso e os interesses populares no processo Constituinte uma marca fundamental. Dessa forma, os PPAs que se sucederam (tomando como parâmetro o governo federal) apresentaram-se como um Projeto de governo, no qual o governante de ocasião, caso não esteja comprometido com a elaboração técnica e detalhada de tal Plano enviesasse as ações do PPA para as prioridades de seu grupo sociopolítico (GARCIA, 2015).

Para o autor, o PPA deve ser concebido com vistas ao atendimento das reais necessidades da sociedade, elegendo o preceito democrático mais amplo na perspectiva do interesse público.

Conceber o plano por problemas e enfrentá-los mediante ações organizadas por programas com objetivos definidos, com a articulação do plano ao orçamento, permite chegar muito mais perto da complexidade do mundo real que na forma tradicional de fazer planejamento e orçamento (função, órgãos da administração e subprogramas referenciados apenas por metas a alcançar). Explicar problemas, chegar às suas causas e conceber ações eficazes (projetos, atividades e ações normativas), definindo com rigor seus produtos - um por ação -, suas metas, seus custos e seus prazos é criar possibilidades para dar partida na adoção do planejamento estratégico público. (GARCIA, 2015, p.63) 
Portanto, tomando o PPA como um documento público que não apenas articula mas também dá diretrizes para os Planos e Leis Orçamentárias do Estado (Orçamento Geral e Lei de Diretrizes Orçamentárias), compreendemos que os PPAs no período proposto para a análise (2008-2015) agregam informações gerais sobre as políticas de esporte planejadas para o DF, constituindo-se um relevante indicador para compreender a concepção destas políticas.

Ao consultar os dois últimos PPAs, foi possível compreender o desenho institucional das políticas esportivas a partir do direcionamento que o GDF deu a esta possibilidade da cultura corporal nas políticas públicas previstas para o período. Os Quadros seguintes trazem essas informações considerando os indicadores propostos pelo Governo em seus PPAs, sua unidade orçamentária e os órgãos gestores responsáveis. É fundamental ressaltar que a ênfase na análise que se segue é dada ao esporte educacional, pois nosso tema de estudo vincula-se a esta possibilidade, não cabendo na discussão das políticas esportivas do DF uma abordagem ou análise mais profunda das ações de esporte vinculadas especificamente a organização de práticas de lazer ou ao esporte de rendimento.

\section{a) Mapa dos Programas / Ações de esporte educacional no DF}

Os Quadros 2 e 3 a seguir ilustram quais ações são previstas e planejadas pelo Distrito Federal para o esporte educacional no período dos últimos oito anos, dando pistas não apenas da compreensão que o Estado impele ao esporte como prática social no contexto da divisão e regulação triádica do esporte, mas ainda do direcionamento de suas ações e desdobramentos em face a essa compreensão mistificada e utilitarista. 
Quadro 2 - PPA 2008 / 2011

\begin{tabular}{|c|c|c|c|c|c|}
\hline PPA & $\begin{array}{c}\text { PROGRAMA } \\
\text { / PROJETO }\end{array}$ & AÇÃO & INDICADORES & $\begin{array}{l}\text { UNIDADE } \\
\text { ORÇAMENTÁ- } \\
\text { RIA }\end{array}$ & EXECUÇÃO \\
\hline \multirow{3}{*}{$\begin{array}{c}2008 \\
- \\
2011\end{array}$} & \multirow{2}{*}{$\begin{array}{l}\text { Juventude e } \\
\text { esporte de } \\
\text { mãos dadas } \\
\text { com o futuro }\end{array}$} & $\begin{array}{l}\text { Construção de } \\
\text { centro esportivo } \\
\text { em escola do } \\
\text { Gama-DF }\end{array}$ & $\begin{array}{l}\text { Número de } \\
\text { bolsas a atletas } \\
\text { federados }\end{array}$ & \multirow{2}{*}{$\mathrm{N} / \mathrm{C}$} & \multirow{2}{*}{$\begin{array}{c}\text { SEL, } \\
\text { Federações; } \\
\text { SEAS e } \\
\text { OSCIP }^{55}\end{array}$} \\
\hline & & $\begin{array}{c}\text { Apoio ao } \\
\text { funcionamento de } \\
\text { Núcleo } \\
\text { Recreativos de } \\
\text { Esporte e Lazer }\end{array}$ & $\begin{array}{l}\text { Número de } \\
\text { crianças e } \\
\text { adolescentes } \\
\text { assistidos }\end{array}$ & & \\
\hline & $\begin{array}{l}\text { Esporte: } \\
\text { Mente e } \\
\text { corpo em } \\
\text { equilíbrio }\end{array}$ & $\begin{array}{c}\text { Infraestrutura } \\
\text { esportiva } \\
\text { (construção e } \\
\text { reforma de } \\
\text { espaços p/ } \\
\text { prática esportiva); } \\
\text { Fomento a } \\
\text { campeonatos } \\
\text { esportivos }\end{array}$ & $\begin{array}{l}\text { Número de apoio } \\
\text { a eventos } \\
\text { esportivos em } \\
\text { diversas } \\
\text { modalidades }\end{array}$ & $\mathrm{N} / \mathrm{C}$ & $\begin{array}{c}\text { Federações; } \\
\text { SEL }\end{array}$ \\
\hline
\end{tabular}

(Fontes: Lei N. 4.007 de 20/08/2007 e Decreto N. 29.933 de 02/01/2009). N/C - não consta

No PPA 2008-2011 (Quadro 2) nota-se a total ausência programática para políticas que abordem especificamente o esporte educacional, ou seja, fica desconfigurado esse preceito constitucional como política esportiva. Cabe destaque ainda a forma de abordagem do esporte diante os objetivos traçados e público alvo: "estimular o esporte apoiando principalmente os jovens, além dos atletas profissionais e amadores [mirando como público alvo a 'população jovem carente (sic)]" (DISTRITO FEDERAL, 2007). Ainda no mesmo PPA, é dado ênfase programática a compreensão do esporte participação, ou lazer, com a presença de uma ação programática específica para investimento em infraestrutura e fomento de campeonatos amadores. Fica demonstrado o empobrecimento no planejamento de ações por parte do Distrito Federal neste período que sinalizem a ampliação do direito a cidadania através do

${ }^{55}$ SEL: Secretaria de Esporte e Lazer; SEAS: Secretaria de Estado de assistência Social; OSCIP: Organização da Sociedade Civil de interesse Público 
esporte, assim como o recrudescimento de ações focalistas e seletivas que reforçam a compreensão fragmentada e mistificada deste bem da cultura humana.

Além da pobreza conceitual, não percebemos neste PPA a presença de quaisquer itens que fundamente, sinalize, direcione, imponha ou determine que setores ou áreas do governo se responsabilizem pela execução das ações propostas, ou ainda a fonte dos recursos. ${ }^{56}$

56 Observando-se a LOA - Lei Orçamentária Anual do ano de 2011, percebe-se que os Programas Esporte: Mente e corpo em equilíbrio e Juventude e esporte de mãos dadas com o futuro encontram fontes de recursos não apenas na pasta Desporto e Lazer, mas em diversas outras (ditas Funções) do GDF, entre elas: Administração, Segurança Pública, Direitos da Cidadania, Urbanismo. Mas essa análise esbarra nos limites da pesquisa, que adota como referência o PPA. Se, conforme já descrito, o PPA é insuficiente para apanhar a fonte de recursos, esta informação vale como indicativo das fontes de recursos dos Programas esportivos do período. Fonte: http://www.orcamentocidadao.df.gov.br/orcamento.php. Acesso: 11/07/2015 


\begin{tabular}{|c|c|c|c|c|c|}
\hline PPA & PROGRAMA/PROJETO & AÇÃo & INDICADORES & $\begin{array}{c}\text { UNIDADE } \\
\text { ORÇAMENTÁRIA }\end{array}$ & EXECUÇÃO \\
\hline \multirow{18}{*}{$\begin{array}{l}2012- \\
2015^{\star *}\end{array}$} & \multirow{7}{*}{$\begin{array}{l}\text { Esportes e Grandes } \\
\text { Eventos Esportivos }^{\prime}\end{array}$} & Escola de Esportes da Sesp & Quantitativo de pessoas beneficiadas & \multirow{7}{*}{$\begin{array}{l}\text { Sesp; } \\
\text { Fundo de Apoio ao } \\
\text { Esporte }^{57}\end{array}$} & \multirow{7}{*}{ Sesp } \\
\hline & & Caravana Esportiva & $\mathrm{N} / \mathrm{C}$ & & \\
\hline & & Compete Brasília & Quantitativo de atletas assistidos & & \\
\hline & & Bolsa Atleta & Quantitativo de pessoas beneficiadas & & \\
\hline & & Projeto Olímpico / Paralímpico & Quantitativo de atletas assistidos & & \\
\hline & & Olimpíadas Escolares & Apoio ao evento & & \\
\hline & & Grandes Eventos Esportivos & Quantitativo de eventos apoiados & & \\
\hline & \multirow{2}{*}{$\begin{array}{l}\text { Garantia do Direito à } \\
\text { Assistência Social" }\end{array}$} & $\begin{array}{c}\text { Construção e reforma de unidades } \\
\text { de CRAS, CREAS, COSEs e } \\
\text { unidade de acolhimento }\end{array}$ & $\begin{array}{l}\text { Quantitativo de unidades } \\
\text { construídas/reformadas }\end{array}$ & \multirow{2}{*}{$\begin{array}{l}\text { SEDEST; Fundo de } \\
\text { Assistência Social } \\
\text { do DF }\end{array}$} & \multirow{2}{*}{ SEDEST } \\
\hline & & $\begin{array}{c}\text { Desenvolvimento de ações de } \\
\text { serviço social }\end{array}$ & Quantitativo de pessoas assistidas & & \\
\hline & Segurança Pública"I' & $\begin{array}{l}\text { Implementação de Projetos Junto à } \\
\text { Comunidade - PMDF }\end{array}$ & Quantitativo de pessoas atendidas & PMDF & $\begin{array}{l}\text { PMDF- } \\
\text { SSPDF/SEDF }\end{array}$ \\
\hline & \multirow{8}{*}{ Educação Básica' } & Centro de Iniciação Desportiva (CID) & $\mathrm{N} / \mathrm{C}$ & \multirow{4}{*}{ SEDF } & \multirow{8}{*}{ SEDF/DIEF 58} \\
\hline & & Jogos Escolares do DF (JEDF) & Realizar os JEDF de forma & & \\
\hline & & Corujão (Jogos do Noturno) & regionalizada em todas as CREs & & \\
\hline & & Ginástica nas Quadras (GinQ) & $\mathrm{N} / \mathrm{C}$ & & \\
\hline & & Nossa Escola Nossa Tribo & \multirow{4}{*}{\multicolumn{2}{|c|}{ Programas planejados, mas não implantados. }} & \\
\hline & & Festival de Cultura Corporal & & & \\
\hline & & Educação Campeã & & & \\
\hline & & $\begin{array}{l}\text { Saúde e Lazer do Trabalhador em } \\
\text { Educação / SALUTE }\end{array}$ & & & \\
\hline
\end{tabular}

(Fonte: Lei N. 4.742 de 29/12/2011). N/C: não consta

57 Criado em 2000 pela Lei complementar № 326 e regulamentado polo Decreto № 34.552 de 16/07/2013.

${ }^{58}$ As ações para o esporte educacional constantes neste PPA são previstas em um órgão denominado DIEF. Entretanto, o órgão não existe, em seu lugar a CEFDESC. Isso ocorreu devido à reestruturação da SEDF ocorrida pelo Decreto № 33.409 de 12 dezembro de 2011. As ações respectivas a Educação Física e esporte escolar cabiam ao órgão denominado DIDESC, que se previa anteriormente à reestruturação se denominar DIEF, mas na reestruturação acabou sendo denominada CEFDESC, permanecendo até os dias de hoje. 
Legenda:

I - Macrodesafio: Propiciar uma educação pública gratuita, democrática e de qualidade social para todos.

II - Macrodesafio: Reduzir as desigualdades sociais, superar a extrema pobreza no DF e RIDE, garantindo renda, acesso aos serviços, gerando oportunidades de emprego e renda nas áreas rural e urbana.

III - Macrodesafio: Garantir segurança pública por meio do uso inteligente dos recursos humanos e tecnológicos.

Já no Quadro 3 percebe-se uma maior preocupação com questões conceituais, operacionais e normativas, expressando um PPA melhor elaborado e conceitualmente reformulado, no intuito de detalhar e referenciar melhor as proposições do Governo para as políticas públicas. As grandes ações do Estado foram desenvolvidas em eixos temáticos que para serem operacionalizados responderam a três dimensões: a Estratégica, a qual é pautada por "Macrodesafios", podendo este ser entendido como Programas estratégicos; a segunda, Dimensão Tática, definiu estratégias e caminhos para materialização do planejamento contido na dimensão estratégica, contendo os Programas Temáticos e Objetivos; já a terceira, Dimensão Operacional, relacionou-se com o desempenho da ação governamental em relação a sua eficiência, diante da previsibilidade ou não de ações orçamentárias.

É perceptível, portanto, um salto qualitativo no detalhamento das propostas e planejamento das ações do Distrito Federal no PPA de 2012 em relação ao anterior. Partindo da compreensão de Garcia (2015), acreditamos que a concepção de um PPA não deva distanciar-se a realidade e da real demanda da sociedade, tendo em seu horizonte que o coletivo das políticas públicas apresentem um potencial para se atingir uma efetiva democratização dessas políticas para se atingir a efetivação dos direitos de cidadania.

Concentrando esforços na análise das políticas de esporte com ênfase para o esporte educacional, o Programa Esportes e Grandes Eventos Esportivos no PPA 2011 - 2015 apresenta-se como o carro chefe das políticas esportivas e de esporte educacional deste período. Ele responde à dimensão tática do Macrodesafio Propiciar uma educação pública, democrática e de qualidade para todos, prevendo em seus objetivos gerais:

- Garantir à sociedade brasiliense o acesso à prática esportiva e inserir Brasília na rota dos grandes eventos esportivos; 
- $\quad$ Pluralidade - Garantir que todas as manifestações esportivas tenham acesso aos recursos disponibilizados pela Sesp, segundo a orientação da Política Pública estabelecida pela mesma;

- Oferecer práticas esportivas educacionais, estimulando crianças, jovens e adolescentes a manter uma interação efetiva que contribua para o seu desenvolvimento integral, incorporando valores éticos, morais e socioafetivos aos participantes do projeto (DISTRITO FEDERAL, 2011).

Também abre espaço para parcerias intersetoriais e também com instituições de direito privado através de parcerias público-privadas ${ }^{59}$ :

\begin{abstract}
Fortalecer o trabalho articulado com as diversas áreas do governo aumentando o nível de participação esportiva de crianças, jovens e adolescentes da comunidade como alternativa preventiva ao uso de drogas e combate à violência; Promover a ocupação de espaços públicos esportivos com programas e projetos desenvolvidos pela Sesp ou em parceria com outros órgãos e entidades da sociedade civil é o primeiro passo para demonstrar os benefícios da prática esportiva rotineira. (DISTRITO FEDERAL, 2011, p. 35)
\end{abstract}

As ações da Sesp que promovem parcerias público-privadas sem um amplo debate na sociedade que permita a prevalência do interesse público caminham na contramão da ampliação de direitos de cidadania, conforme já demonstrado anteriormente por Montaño (2010). Este afirma que o esvaziamento do papel do Estado através da transmissão de responsabilidades sociais fortalece a lógica da acumulação de capital e desconstituição de direitos sociais.

A focalização também é anunciada como estratégia da Secretaria de Estado de Esporte (Sesp) ${ }^{60}$ :

\footnotetext{
${ }^{59}$ Isso aconteceu, por exemplo, com os Centros Olímpicos no período entre 2008 e 2011, ano em que o Ministério Público recomendou o encerramento das gestões privadas destes equipamentos públicos por OnGs e OSClps e sua imediata reabsorção pelo Estado. Isso se deu por força de uma decisão do Tribunal de Justiça do Distrito Federal e Territórios sobre uma Ação Direta de Inconstitucionalidade ajuizada pelo Ministério Público do DF, a qual questionava a lei de concessões criada pelo GDF para permitir as terceirizações (Lei Distrital $N^{\circ} 4.081 / 2008$ ). No bojo dessa decisão, argumentou-se a ausência do esporte no rol dos elementos que podem celebrar contratos de gestão entre o Estado e "organizações sociais" na lei federal que cuida dos contratos de gestão entre o Estado e essas organizações (Lei No 9.637/1998).

${ }^{60}$ É importante afirmar que a Secretaria de Estado de Esporte (Sesp) passou a integrar a Secretaria de Educação do Distrito Federal através do Decreto № 36.828 de 23/10/2015, a qual passou a ser denominada Secretaria de Educação, Esporte e Lazer do Distrito Federal. Assim como ocorrido com a CEFDESC, tal iniciativa é contemporânea ao encerramento deste trabalho, portanto, toda informação e/ou análise que tangencia ou se remete à participação da Sesp nesta pesquisa fora mantida de forma a preservar a autenticidade e fidedignidade dos dados encontrados no decorrer de sua elaboração.
} 
Nesse contexto serão priorizadas ações em áreas com menor IDH seguindo a estratégia de apresentar a prática esportiva como forma de inclusão social, de socialização, de respeito e de melhoria da qualidade de vida, associada a atividades continuadas com a implementação de programas e projetos próprios ou de parceiros, visando despertar na comunidade a proatividade, a fim de que a mesma seja condutora da cultura da prática esportiva em sua localidade (DISTRITO FEDERAL, 2011, p. 35)

O Governo, através do Programa Esportes e Grandes Eventos Esportivos, destaca o protagonismo do esporte de Alto Rendimento como gatilho para as outras possibilidades manifestas do esporte na organização triádica impingida a este bem da cultura corporal, ressaltando a relevância da iniciativa privada no esporte de alto rendimento:

O esporte de alto rendimento possui grande poder de visibilidade, envolvimento emocional e capacidade de captação de recursos financeiros. Há, portanto, uma concentração histórica de investimentos nessa manifestação. A Sesp tem a preocupação com a distribuição mais equânime desses recursos por entender que a função primordial do Estado é investir no esporte educacional e de participação, atuando com a iniciativa privada no esporte de alto rendimento. Para esta finalidade, aperfeiçoa programas e projetos já existentes, desenvolvidos nas escolinhas de esporte e vilas olímpicas. (DISTRITO FEDERAL, 2011, p. 36)

Cabe a reflexão sobre esta iniciativa: o Estado declara atuar conjuntamente com a iniciativa privada na questão de Esporte de Alto rendimento, ao tempo em que fomenta iniciativas que refletem a lógica do esporte de rendimento através de suas escolinhas esportivas, vilas olímpicas e também no seu apoio direto ao esporte escolar através do financiamento aos Jogos Escolares e ao bolsa-atleta. Sobre essas primeiras, a Secretaria de Esporte do Distrito Federal (Sesp) promove não somente a prática esportiva para saúde, mas também a formação esportiva de base:

As escolas de esportes da Secretaria do Esporte e Lazer do Distrito Federal têm o objetivo de incentivar à prática esportiva entre crianças, adolescentes, adultos e idosos; estimular o hábito de vida saudável; estimular o servidor público à prática física diária e formar equipes esportivas que possam revelar talentos para o cenário local e nacional. ${ }^{61}$

61 Disponível em http://www.esporte.df.gov.br/escola-de-esporte/informacoes-gerais.html. Acesso: 18/03/2015 
Já sobre o planejamento que aborda diretamente o esporte educacional (este, em sua forma institucionalizada e regulamentada) é demonstrado no PPA que não há clareza sobre o seu conceito e seus desdobramentos. Este se apresenta no Planejamento compreendido explicitamente como prática esportiva de viés competitivo e seletivo em ambiente escolar (que na subdivisão regulamentada pelo Decreto № 7.984/2013 é atribuída ao esporte escolar). E, como se pode verificar no PPA, para esta essa perspectiva observa-se garantias institucionais, orçamentárias e estratégicas através de ações como a concessão de "bolsa atleta" para estudantes desportistas (apenas aqueles inseridos nas modalidades dos Jogos da Juventude), passagens aéreas e terrestres através do Programa Compete Brasília para representação em competições nacionais ou internacionais, Vilas Olímpicas (escolinhas de iniciação e treinamento desportivo) e apoio a eventos como as Olimpíadas Escolares, citando alguns de seus principais.

Também cabe destaque o planejamento para investimento em infraestrutura (reforma e construção), este atrelado à concepção original da Sesp sobre ampliação e fomento da prática desportiva. Essa concepção, conforme temos percebido, atende diretamente a lógica da pirâmide esportiva, pois anuncia com clareza a formação de atletas através das proposições para o manifesto esporte educacional no âmbito da Sesp. Sua política também caminha ao encontro da lógica da focalização das políticas públicas, posto a priorização de regiões com baixo índice de desenvolvimento humano (IDH). Mas não apenas isso, as políticas públicas concebidas pela Sesp descartam e marginalizam uma compreensão de esporte como elemento da cultura corporal, patrimônio da humanidade para satisfação de suas necessidades básicas e de fruição livre do seu tempo de lazer, afastando-se da possibilidade de alcance da emancipação humana e direitos de cidadania através da prática do esporte.

O Programa Temático Esporte e Grandes Eventos Esportivos não somente prevê ações que abordam o esporte educacional (ao menos em anúncio), mas o prevê também (e principalmente, conforme discutiremos adiante) ações e investimentos maciços na preparação, organização dos Megaeventos Copa das Confederações, Copa do Mundo Fifa 2014 e Olimpíadas Rio 2016. Planeja também a investimentos em infraestrutura esportiva, tanto para a prática desportiva da comunidade, "atentando-se para critérios de descentralização e IDH" (DISTRITO FEDERAL, 2011, 
p. 36) mas especialmente para possibilitar a realização de tais Megaeventos (reforma e construção de espaços, tais como o Estádio Nacional Mané Garrincha ${ }^{62}$ ).

Para além dos domínios da Sesp, também se percebe a presença do esporte educacional neste PPA em outras ações desenvolvidas por diferentes setores governamentais, ora compreendido por "Macrodesafios". O esporte educacional está presente no planejamento das ações da Secretaria de Estado de Desenvolvimento Social e Transferência de Renda do DF (SEDEST) por meio da intervenção dos educadores vinculados a esta secretaria através da atuação especializada denominada Assistente Superior em Serviços Sociais - Educador Social, com atuação na área de esporte e lazer nos Centros de Orientação Socioeducativa (COSES), Centros de Referência Especializados de Assistência Social (CREAS) e na Gerência de Ações Especiais (GAE), no âmbito da SEDEST. Ainda que o esporte educacional não se apresente ipsi literis no PPA para esta pasta, se apresenta através do Programa Temático "Garantia do Direito à Assistência Social”, prevendo a ampliação do atendimento e da infraestrutura dos locais de atendimento.

Sua intervenção, ao menos no discurso, ultrapassa a visão utilitarista de esporte e Educação Física, muito presente na proposta da pasta específica, a Sesp. Cabe ao educador social

\begin{abstract}
Construir proposta de oficina de esporte e lazer que contribua para o desenvolvimento biopsicofisiológico e social do usuário da assistência; identificar os diferentes atores sociais envolvidos ou que tenham articulação entre as instituições responsáveis pelo ensino formal e por projetos de esporte e lazer, preservada a área de abrangência da unidade de lotação, visando parcerias e garantindo o trabalho em rede; [...] promover prática educativa de esporte inclusiva, com atividades recreativas, formativas e sociais; planejar e executar atividades físicas e recreativas voltadas para o desenvolvimento biopsicofisiológico visando o desenvolvimento físico e mental; organizar e executar campeonatos, gincanas, jogos de diferentes modalidades esportivas internamente e com outros segmentos comunitários; planejar e executar atividades que favoreçam o condicionamento físicocorporal, visando à consecução do bem estar e da qualidade de vida dos usuários; [...] promover a inclusão do usuário nas atividades esportivas e de lazer da comunidade; planejar e executar projetos sociais para a área de esporte e lazer. (DISTRITO FEDERAL, 2008, p. 70)
\end{abstract}

$62 \mathrm{O}$ estádio tem o orçamento atualmente aproximado ao valor de $\mathrm{R} \$ 1,8$ bilhão. Segundo o Tribunal de Contas do DF, este valor ainda não corresponderia à contabilidade final, pois algumas obras até abril/2015 relacionadas a urbanização, paisagismo e uma estação de energia solar não haviam sido contabilizadas. (Fonte: http://noticias.r7.com/distrito-federal/custo-do-mane-garrincha-podeultrapassar-r-18-bilhao-segundo-tribunal-de-contas-do-df-25042015. Acesso: 16/07/205) 
Já nas ações anunciadas pela Secretaria de Segurança Pública do DF (SSPDF) podemos perceber a presença do esporte educacional no Programa temático Segurança através na ação denominada Implementação de Projetos Junto à Comunidade - PM. Um de seus principais expoentes certamente é o Programa Esporte à Meia-Noite, realizado através de parceria entre a Secretaria de Estado de Segurança Pública (SSPDF) e a SEDF. O Programa, criado em 1999 na intenção de retirar das ruas em horário noturno jovens com potencial para a delinquência e o uso de drogas, foi repaginado em 2011 e circunscrito ao Programa "Segurança Comunitária em Ação Pró-Comunitária, o qual objetiva "prevenir e enfrentar o uso do crack e de outras drogas, a violência, a criminalidade, a discriminação e a intolerância e tendo, como objetivo, contribuir para a construção de uma sociedade livre, justa e solidária"63. Um exemplo claro da mistificação do esporte com viés utilitário, pois tal Subprograma, em articulação com outros que preveem articulação com os campos da saúde e cultura, utiliza o potencial educativo do esporte para solucionar problemas sociais sem abordar questões importantes como o viés pedagógico de tais iniciativas, a interdisciplinaridade, execução, culminância e avaliação de tais ações.

Tal ação, classificada como "Subprograma" da SSPDF, é organizada em ato conjunto entre as duas secretarias de forma que à SEDF cabe a cessão dos recursos humanos (professores de Educação Física) espaços físicos (escolas, quadras e toda infraestrutura escolar), realizar cursos de requalificação e garantir o acesso desses trabalhadores ao Programa. Já à SSPDF caberia além de controlar a vida funcional dos trabalhadores cedidos, executar, avaliar e controlar as ações do Subprograma, salientando que essas ações são restritas e exclusivas à PMDF64 (DISTRITO FEDERAL, 2014).

Suas ações são referenciadas no Plano Plurianual 2012/2015 através do objetivo específico 03 do Programa Esporte e Grandes Eventos Esportivos: "Construir e manter uma rede de infraestrutura que propicie a prática esportiva no Distrito Federal" (DISTRITO FEDERAL, 2011), justificando que objetiva e preza pelo

\footnotetext{
63 Decreto No 33.245, de 05 de outubro de 2011.

$64 \mathrm{Em} 07$ de julho de 2015 o Governo do Distrito Federal tomou a medida de suspender as atividades do Programa Esporte à Meia-Noite, justificando essa paralisação pela necessidade de reestruturação do Programa. Ao mesmo tempo, anuncia que os trabalhadores cedidos à SSPDF (professores) estão devolvidos ao órgão de origem (SEDF) para discutir e reavaliar o Programa, afim de estabelecer um novo formato para o mesmo e reiniciando as atividades em agosto do corrente ano. Fonte :http://www.df.gov.br/conteudo-agencia-brasilia/item/19950-nota-oficial-programa-esporte-\%C3\%A0meia-noite.html. Acesso: 16/07/2015
} 
"desenvolvimento do esporte na Capital da República e pela melhoria da qualidade de vida da população como fundamental garantia da oportunidade do acesso à prática esportiva para a presente e futuras gerações" (IDEM, p. 43), ainda que anuncie o controle da violência e o combate às drogas dentre seus objetivos. Isso demonstra a fragilidade programática e administrativa desta política intersetorial em relação ao planejamento desta ação prevista em tal PPA tanto no âmbito da gestão (controle, financiamento) quanto do controle social, amparado pelo viés mistificado e utilitário do esporte (FLAUSINO; MASCARENHAS, 2012).

Ainda no escopo do Programa Temático Segurança Pública há referências a planejamento em atividades comunitárias em seu objetivo específico "Ampliar o atendimento à comunidade brasiliense, por meio dos projetos sociais desenvolvidos pela Polícia Militar, buscando melhoria no inter-relacionamento entre polícia e comunidade" (DISTRITO FEDERAL, 2011). São desenvolvidos projetos sociais esportivos pela PMDF nas cidades de Santa Maria (Futebol; cujo lema é: "Revelar Craques, Formar Cidadãos), Brazlândia (jiu jitsu), Gama (futebol - escolinha Bom de Bola), Taguatinga (jiu jitsu, submission, ginástica laboral e funcional) e Ceilândia (futebol: Bom de Bola, Bom na Escola) ${ }^{65}$. Tais ações correspondem a prática esportiva em projetos sociais, e segundo o Decreto $N^{\circ} 7.984$ de abril de 2013, a prática esportiva em ambientes escolares ou não escolares que se paute princípios socioeducativos, tais como aquele praticado em projetos sociais atendem à perspectiva do esporte educação.

À sombra da letra fria da lei, cabe a discussão sobre que valores ou princípios socioeducativos a PMDF desenvolveria sem seus projetos sociais esportivos, problematizando que formação esportiva, que acúmulo na área educacional e compreensão do processo educativo através do esporte esses agentes possuem. $O$ Professor 1, entrevistado em nossa pesquisa, pode nos dar uma pista quando discorre sobre os Projetos esportivos que ele julga concomitantes ao Projeto CID em sua região:

${ }^{65}$ Fonte: http://www.pm.df.gov.br/site/index.php/institucional/projetos-sociais. Acesso: 10/04/2015 
Este ano, por exemplo, [...] é um ano que eu estou com um pouco mais de dificuldade na questão de números dos alunos participantes [...] a gente percebe que tem outras ofertas que estão concorrendo com aquela oferta do CID naquele determinado momento. [...] Então, você tem um Projeto da Marinha - que pega um ônibus, vai até lá, pega as crianças, leva até o clube da Marinha e eles passam a manhã na Marinha. Tem sua característica interessante, mas tem o outro lado que é assim: não tem um cuidado; não tem uma intenção naquela ação! Você tem um Cabo que passa a manhã com uma criança! Então, ele cuida: tem ali um joguinho, tem alguma coisa, mas, não tem uma intenção! (PROFESSOR 1) ${ }^{66}$

Já no Programa Temático Educação Básica percebe-se a presença de diversas ações que abordam diretamente o esporte educacional, dentre elas o objeto de estudo desta pesquisa, o Projeto CID. Dentre as ações previstas neste Programa Temático, apenas o Projeto CID e os Jogos Escolares do Distrito Federal (JEDF) efetivamente se consolidaram. O CID, inaugurado em 1981 (QUIRINO, 2012), conta atualmente com 147 unidades (ora denominado polós) de atuação em 14 Regiões Administrativas do $\mathrm{DF}^{67}$. Já o JEDF ${ }^{68}$, que em 2015 encontra-se em sua 55a edição, não parece ter consolidado a meta prevista de "Realizar o JEDF de forma regionalizada em todas as CRE”. 69

Após o contato com este o panorama das políticas esportivas previstas nos Planos Plurianuais 2008-2011 e 2012-2015, período de análise sugerido para esta pesquisa, no próximo movimento tentaremos compreender e discutir as políticas de esporte educacional nesse contexto.

\footnotetext{
${ }^{66}$ Será adotada nesta pesquisa a estratégia de transcrição conforme Duarte (2004). A autora compreende que as entrevistas devem ser editadas em relação ao seu conteúdo coloquial, de forma a valorizar o entrevistado e dar maior organicidade e legitimidade ao trabalho do pesquisador.

${ }^{67}$ Fonte: CEFDESC, abril/2015

${ }^{68}$ É importante ressaltar que este evento de esporte escolar abrange estudantes da rede pública e rede privada de ensino, portanto, apesar de configurar-se através da iniciativa pública, não assume o caráter de gratuidade e publicidade na magnitude do Projeto CID.

69Fonte: Regulamento Geral JEDF 2015. Disponível em http://escolas.se.df.gov.br/cefdesc/images/REGULAMENTOS/regulamento jedf 2015.pdf. Acesso: 30/06/2015.
} 


\section{b) Discutindo a presença do esporte educacional nas políticas esportivas do DF}

Para situar a discussão e análise das ações e investimentos no esporte, em torno das informações descritas no item anterior, em especial o esporte educacional, é interessante recorrer ao trabalho de Carneiro (2013). O autor, para pesquisar a política dos Centros Olímpicos percorreu de forma detalhada as propostas contidas nos dois últimos PPAs, realizando o exercício de analisar se tais políticas possibilitam a democratização do esporte no Distrito Federal através dos princípios da universalidade e direitos de cidadania, postulando que este se constitui um satisfador das necessidades básicas do ser humano. Para tal, adotou como referência a proposta de dimensões sociais do esporte em Tubino (2011): esporte participação, esporte rendimento, esporte educação ${ }^{70}$.

Em relação ao PPA 2008/2011 Carneiro (2013) percebeu que o GDF priorizou as ações que favorecessem o esporte denominado de alto rendimento em detrimento as demais categorias. Ele percebeu nesta categoria uma ênfase em Programas que se materializavam de maneira focalista (voltado para jovens "pobres") ou seletistas (para atletas), não ficando configurado através dessas ações, a garantia do direito ao esporte. Ainda chama a atenção para a inclusão em um dos programas desta categoria, por força da Lei № 4.495 de 2010 a reforma e ampliação do estádio Mané Garrincha para a Copa do Mundo FIFA 2014, reforçando essa sua análise de priorização dos Megaeventos Esportivos, o que favorece, segundo ele, a perspectiva do esporte de rendimento.

Por outro lado, neste PPA ele identificou ações enquadradas na categoria participação com vieses universalistas, mas, ao perceber a proporcionalidade relativa a abrangência e a população do DF, o autor descreve a insuficiência destas ações tanto em quantidade quanto em perspectiva para serem, de fato, tidas como universais. Também chama a atenção para, dentro da categoria esporte participação, a presença de diversas ações e investimentos em infraestrutura, discutindo a

\footnotetext{
70 Ainda que não nos vinculemos a esta subdivisão triádica, conforme debate já estabelecido nos capítulos anteriores, há de se ressaltar que de forma hegemônica nas legislações que abarcam o esporte esta subdivisão prevalece, organizando e referenciando as ações e indicadores para suas políticas, ganhando terreno também na produção acadêmica que se propõe a estudar o tema.
} 
relevância dos planos de utilização para que as ações educativas se democratizem, de fato:

[...]além de espaços físicos, é preciso que as políticas esportivas tenham atividades a serem desenvolvidas, pois somente a presença do espaço físico não é suficiente para o atendimento ao direito ao esporte. Dessa forma, à medida que temos o planejamento de gastos da política esportiva mais direcionada a um programa que visa construir espaços físicos e não para o desenvolvimento de atividades, temos limites para a concretização do direito ao esporte. (CARNEIRO, 2013, p. 110)

É importante ressaltar que de todas essas ações descritas por Carneiro (2013) sob a responsabilidade da Secretaria de Esporte do DF, não foi descrita uma sequer que possa ser compreendida como esporte educacional. Já no PPA 2012/2015, o Programa Temático "Esporte e Grandes Eventos Esportivos" abarcou ações respectivas as ditas três dimensões do esporte, segundo descrição do autor, e cujo nome já anuncia seu objetivo principal: colocar Brasília na rota dos Megaeventos Esportivos. E o autor já inicialmente coloca que esta iniciativa se estabelece como um contraponto ao direito ao esporte:

\begin{abstract}
Apontamos que os megaeventos esportivos estão associados ao esporte de alto rendimento, cuja prática se dá por poucos participantes. Mesmo o acesso para assistir ao espetáculo esportivo na Copa do Mundo de Futebol 2014 e nas Olimpíadas de 2016 será restrito, pois, conforme vimos no início deste capítulo, as desigualdades sociais são gritantes no Distrito Federal. Logo os trabalhadores, ou mesmo os excluídos sociais, não terão condições de comprar os ingressos para ter acesso ao espaço que foi financiado por eles mesmos. (CARNEIRO, 2013, p.111)
\end{abstract}

Ele descreve que o programa temático "Esporte e Grandes Eventos Esportivos" mesmo ao mencionar as três dimensões do esporte como iniciativas previstas dentre suas ações, não garante a integralidade desse atendimento dado a superficialidade conceitual de suas proposições e contradições encontradas entre estas e as ações executadas.

Isso fica demonstrado quando Carneiro (2013) quantifica as ações para a categoria esporte educação. Primeiramente, em seu principal Programa Temático o esporte escolar é anunciado como ação de esporte educacional através de incentivos 
como a bolsa-atleta ${ }^{71}$. Em seguida, quando prevê 11 ações voltadas para as categorias esporte rendimento e esporte participação, mas apenas 2 voltadas para esporte educação. Em terceiro, que as ações planejadas para o esporte participação e o esporte educação estão embebidas pela lógica do olimpismo ${ }^{72}$, o que acaba por ratificar, de fato, a preponderância do esporte competitivo em ambiente escolar representado em seu ápice pelo esporte rendimento. Todas essas ações, destaca o autor, encontram-se circunscritas à Secretaria de Esportes. Já para as ações circunscritas à SEDF, o autor destaca o avanço contido no PPA 2012-2015 em relação ao anúncio da perspectiva de emancipação e criticidade que as propostas apresentam, pois, esta pasta propõe o desenvolvimento de

[...] programas, projetos e ações de esporte e lazer que ampliam o atendimento a todos os estudantes da Educação Básica e comunidade. Para uma Educação Física que contribua para a emancipação humana, a DIEF tem como um dos papéis a ampliação, manutenção e construção de espaços, aquisição de materiais e equipamentos adequados ao pleno desenvolvimento dos seus projetos e programas. (DISTRITO FEDERAL, 2011, s. p apud CARNEIRO, 2013, p.119)

Sobre o financiamento e o direcionamento dos gastos, Carneiro (2013) analisa que cerca de $80 \%$ do gasto do Estado no DF com política de esporte, previsto no PPA 2012-2015 é direcionado para a realização de Megaeventos, atendendo, segundo ele, ao desenvolvimento da categoria esporte rendimento, enquanto os demais $20 \%$ atendem às outras possibilidades/manifestações do esporte.

O autor aponta que ações intersetoriais foram planejadas de forma a atender ao terceiro objetivo do Programa Temático "Esportes e Grandes Eventos Esportivos" (a exemplo de ações de Segurança pública, infraestrutura, turismo, etc.). Cabe ressaltar que os Centros Olímpicos (espaços públicos que segundo o autor são destinados para a prática de esporte e lazer) também abre suas portas para o Projeto

\footnotetext{
${ }^{71}$ A categoria esporte escolar prevista no Decreto № 7.980 de abril/2013 ratifica a presença normativa da competição escolar e favorece a lógica da pirâmide esportiva e a consequente não-consolidação de direitos conforme debate no capítulo anterior referenciado em Mascarenhas (2012) e Seron (2013). 72 O Olimpismo seria uma fusão por parte do Barão Pierre de Coubertin do esporte educacional inglês do séc. XIX com os fundamentos humanísticos dos Jogos esportivos da Grécia Clássica (TAVARES, 2005). Conforme já discutimos anteriormente, tal movimento se idealiza como o ápice da Educação Física escolar, e foi difundida no Brasil através da Carta Internacional de Educação Física e do Esporte da UNESCO, não apresentando condições de dar respostas às contradições de nossa realidade escolar e das aspirações necessárias à formulação de uma Educação Física crítica e do esporte como um satisfador das necessidades humanas.
} 
CID, segundo a declaração do Gestor do Projeto em âmbito central, identificado em nossa pesquisa como Gestor Central 1:

[...] existe um termo de cooperação da Secretaria de Educação com a Secretaria de Esporte que prevê a utilização dos Centros Olímpicos pelo Centro de Iniciação Desportiva ${ }^{73}$. Então seria a cessão do espaço que hoje é gerido pela Secretaria de Esportes para que os CIDs funcionassem lá dentro. Hoje, nós temos alguns exemplos disso principalmente no desporto paralímpico, desporto adaptado, temos alguns CIDs que funcionam dentro dos Centros Olímpicos. Além disso, alguns CIDs de atletismo também hoje funcionam dentro dos Centros Olímpicos e a ideia é ampliar isso. (GESTOR CENTRAL 1)

Tal perspectiva materializa a possibilidade de uma ação intersetorial entre Sesp e SEDF conforme prevê o PPA. Ao mesmo tempo que possibilita a abertura de um espaço público consolidado para a prática deste elemento da cultura corporal, abre possibilidade para que se fortaleça de maneira sutil a vinculação deste Projeto de esporte educacional à lógica da formação esportiva de base, submetendo esta ação a uma lógica distinta da emancipação humana, pois esta atividade é compreendida por Castellani Filho (2008) como uma resposta do homem às suas necessidades sociais ao longo do processo civilizatório em que se encontra. Destarte, a vinculação do esporte como politica pública educacional à lógica da usurpação de direitos, assim como da capitalização de sua intervenção por intermédio da organização da pirâmide esportiva, se distancia da efetivação de direitos.

Entendemos com clareza até o momento que há uma forte inclinação nas políticas de esporte do Distrito Federal nos últimos 8 anos, dois últimos PPAs, do movimento anunciado por Pereira; Stein (2010) e Matias (2014): a focalização das políticas. Esse movimento responde à dinâmica engendrada pelo desenho políticoinstitucional das políticas esportivas em nosso país, conforme percebemos no capítulo anterior e, sobremaneira, não atende à perspectiva de democratização, ampliação de direitos e direitos de cidadania, pois responde à manutenção da ordem social estabelecida, a qual subjuga os homens a condição de alienados e destituídos de sua

\footnotetext{
${ }^{73}$ Tal documento corresponde ao Termo de Cooperação Técnica 10/2012, regulamentado pela Portaria $\mathrm{N}^{\circ} 42$ de 25/02/2013 da SEDF.
} 
humanidade, já que (mais) um satisfador de suas necessidades humanas básicas é estratégica e perniciosamente submetido à lógica do grande capital.

E sobre essa representação, Húngaro (2008) percebe que a reprodução da vida social, na qual se insere o esporte, prática historicamente situada, produto da cultura humana, rica em sentidos e significados, encontra-se subsumida à forma de organização social, desde a produção de suas riquezas como também na reprodução das relações que se estabelecem entre os homens.

\begin{abstract}
Assim, da maneira de produzir a existência erguem-se estruturas complexas que são resultados, mas, também, determinações intervenientes no modo de produção. Ao trabalhar, portanto, nós produzimos a nossa existência e ao mesmo tempo reproduzimos a vida social. Nesse processo estabelecemos relações sociais, independentes da nossa vontade, que são representativas do grau de desenvolvimento da totalidade social. Numa sociedade na qual somos em virtude da divisão social do trabalho, obrigados a sermos força de trabalho, nada mais "natural" que ao sermos questionados sobre o que somos respondamos pelo que temos (mercadoria força de trabalho): "marceneiro"; "tecelão"; "metalúrgico" etc. Essa é a nossa maneira de ser. Por vivermos num marco histórico em que as relações sociais de produção se estabelecem a partir da propriedade privada, a apropriação do desenvolvimento genérico depende do quanto se é proprietário. Produção, reprodução individual e reprodução social constituem, portanto, uma totalidade de complexos. (HÚNGARO, 2008 p.207).
\end{abstract}

Essa dialética entre os homens e sua forma de organização social reproduz-se também na política, já que esta é compreendida por Pereira (2008) não apenas como atividade do Estado (estrito), mas como atividade das pessoas em expressar seus interesses e objetivos no âmbito das relações desiguais/diferentes entre os seres humanos: "É, enfim, a política que permite a organização do social como espaço instituído, historicamente construído e articulados por conflitos, propiciando a diversificação e a multiplicação de direitos de cidadania" (PEREIRA, 2008, p. 91). Se, conforme a autora, sua materialização pelo Estado é expressa pelas políticas públicas, podemos tomar emprestado o conceito gramsciano de hegemonia para compreender a dinâmica imposta por esta "totalidade de complexos" (HÚNGARO, 2008) que referenda o planejamento e execução das políticas públicas para o esporte educacional.

E, após identificar o Projeto Centro de Iniciação Desportiva nas políticas esportivas do Distrito Federal, cabe-nos agora uma aproximação mais imediata para buscar suas nuanças e compreender o quanto desta lógica hegemônica observada 
nas políticas esportivas interferem na experiência desta política de esporte educacional.

\section{O Projeto Centro de Iniciação Esportiva}

Fundado em 1981 (QUIRINO, 2012), o Projeto Centro de Iniciação Desportiva propõe-se possibilitar aos alunos da Rede Pública de Ensino do DF o conhecimento técnico e tático de diversas modalidades esportivas, tendo em seu horizonte não apenas a diversificação das atividades da Educação Física escolar, mas a possibilidade de formação esportiva em nível competitivo (SEDF, 2012a). Corroborando com as constatações de Liggieri (2014) são escassos, para não dizer quase inacessíveis os registros documentais ou bibliográficos que remetam à história inicial do Projeto CID, ficando a cargo dos registros orais e relatos dos atores mais antigos desta política seu desenvolvimento histórico em suas fases iniciais. Todavia, existe atualmente um amplo espectro legal/normativo que referenda o Projeto.

Inicialmente, tal política é referenciada pela Lei Orgânica do Distrito Federal promulgada em 1993, doze anos após a fundação do Projeto, a qual incorpora a presença do esporte nas aulas de Educação Física através de seu art. 233, parágrafo $1^{\circ}$, Ihe conferido o status de direito do estudante e dever do Estado. A Carta Magna do DF garante também a presença da manifestação hoje entendida com esporte escolar através da obrigatoriedade da criação de turmas especiais para aqueles(as) que demonstrem talento esportivo.

Capítulo IV Seção I - da Educação

Art. 233 - A educação é direito de todos e deve compreender as áreas cognitiva, afetivo-social e físico-motora.

$\S 1^{\circ} \mathrm{A}$ Educação Física e a educação artística são disciplinas curriculares obrigatórias, ministradas de forma teórica e prática em todos os níveis de ensino da rede escolar.

$[\ldots]$

$\S 3^{\circ}$ Será estimulada a criação de turmas especiais a fim de preparar alunos que demonstrem aptidão e talento para o esporte de competição. (DISTRITO FEDERAL, 1993) 
Ainda em seu art. 255, alínea I, a Carta Magna do DF reverbera o texto do Art. 227 da C.F., asseverando que

"As ações do Poder Público darão prioridade: I - ao desporto educacional e, em casos específicos, ao desporto de alto rendimento, respeitado o tratamento diferenciado para o desporto profissional e o não profissional" (DISTRITO FEDERAL, 1993).

Ao perceber-se a consonância desta normatização ao texto da CF para o esporte de forma geral e o esporte educacional, esta ação normativa do Estado certamente possibilitaria a formulação de políticas voltadas para seu desenvolvimento como prática educativa no Distrito Federal. Mas, apenas onze anos mais tarde, segundo a Lei 3.433 de 2004, regulamentada um ano após pelo Decreto $N^{\circ} 26.280$ de outubro de 2005, o Projeto foi institucionalizado e normatizado com a definição de suas especificidades.

Art. $1^{\circ}$ Fica assegurado aos alunos das escolas públicas do Distrito Federal matriculados nos ensinos fundamental, médio e especial, o acesso a Centros de Iniciação Desportiva - CID.

Parágrafo único. O acesso de que trata o "caput" deste artigo ocorrerá em turno contrário às atividades curriculares contínuas.

Art. $2^{\circ} \mathrm{O}$ Centro de Iniciação Desportiva deverá identificar e desenvolver talentos na área desportiva, como também, incentivar e encaminhar o aluno/atleta ao Programa Geração Campeã ${ }^{74}$. (DISTRITO FEDERAL, 2005)

O Projeto CID também se fundamenta na Lei N 9.394 de dez/1996, a LDB, a qual recomenda em seu Art. 27, inc. IV a "promoção do desporto educacional" (BRASIL, 1996) e na Lei Nº 9.615 de março/1998 (Lei Pelé), regulamentada pelo Decreto № 7.984 de 2013.

No âmbito da SEDF, o Projeto é desenvolvido, coordenado, fiscalizado e avaliado pela Coordenação de Educação Física e Desporto Escolar (CEFDESC) ${ }^{75}$

\footnotetext{
${ }^{74}$ Política de captação e desenvolvimento de alunos da SEDF com potencial esportivo extinto em 2010. Devido ao seu insucesso como política de esporte, os referenciais na literatura sobre este Programa são quase inexistentes, não sendo possível a este pesquisador o acesso a seus registros.

${ }^{75} \mathrm{~A}$ unidade de gestão CEFDESC nasce em substituição à sigla DIEF, constante nas proposições para o PPA, conforme já elucidado anteriormente. O mandato onde fora realizada tal mudança foi o do governador Agnelo Queiróz do Partido do Trabalhadores. Ministro dos Esportes no $1^{\circ}$ mandato do
} 
com apoio institucional das estruturas gestoras descentralizadas denominadas Coordenações Regionais de Ensino (CREs). No Projeto CID as CREs têm a incumbência de regular a vida funcional do docente, assim como realizar a mediação administrativa entre este, a UE onde a unidade do Projeto é sediada (denominada pólo do CID) e seus alunos matriculados (SEDF, 2012a). Há, por conseguinte, a centralização de duas ações fundamentais - concepção, e avaliação - com atuação restrita e operacional das unidades descentralizadas através da figura do Coordenador Intermediário, conforme afirma o Gestor Central 1.

[...] a estrutura do CID é coordenada num nível intermediário e um nível central. A nível intermediário a gente tem a figura do coordenador de Educação Física, que no momento são dois coordenadores, esses professores são formados em Educação Física são vinculados à Regional de Ensino, a uma Gerência que chama Gerência de Educação Básica e eles são responsáveis por coordenar a nível regional o Projeto. Dentre uma das atribuições eles coordenam esses professores e fazem o trabalho de supervisão junto a eles. No nível Central a Coordenação de Educação Física e Desporto Escolar tem uma gerência que chama Gerência de Práticas Corporais que é responsável também pela coordenação do Projeto através do Núcleo de Iniciação Desportiva. Esse trabalho é feito através de coordenações pedagógicas: o professor faz semanalmente ou com o coordenador intermediário ou na escola onde ele é lotado [possui sua lotação funcional] e coordenações também com o nível central. Os intermediários fazem essas coordenações mensalmente e diante da demanda e necessidade, é convocada uma reunião com os professores de uma forma geral para fazer essa reunião junto com a coordenação do nível central. Além disso, os professores preenchem diários, cuja orientação é que esses diários fiquem sempre na escola e eles têm que produzir um relatório bimestral que enviam para o coordenador intermediário, que depois envia para a coordenação de nível central. E através desses relatórios é feito o diagnóstico, levantamento dos dados dos atendimentos para compilação, produção de relatorias gerais e, nos casos onde chama atenção, que ocorrem algum problema, entra em contato com o professor, a gente faz visitas em lócus para verificar como está o Projeto. (GESTOR CENTRAL 1)

governo Lula, Agnelo implementou no Distrito Federal uma lógica de gestão já trabalhada nos mandatos do PT em âmbito federal, a qual é descrita em sua contradição capital por Singer (2012) por apresentar traços de "conservação e mudança, reprodução e superação, decepção e esperança num mesmo movimento" (SINGER, 2012, p. 9).

A prática política em relação ao esporte, portanto, foi capitaneada por Agnelo em relação aos Megaeventos iminentes no DF, mas o grande volume das políticas de esporte e lazer expressos no Programa Temático "Esporte e Grandes Eventos Esportivos" estiveram nas mãos de pessoas que já possuem suas raízes na Sesp há várias décadas e, nesta ocasião, fora capitaneado por partidos políticos da coalisão de governo sem muito acúmulo histórico no tema. Essa tendência conservadora contribuiu, conforme pondera Singer (ibid.) para demover a "esperança" no sentido de mudanças nas políticas esportivas que sinalizassem sua efetiva democratização no período deste mandato. 
Seu instrumento normativo e conceitual principal é a Orientação Pedagógica (OP) do CID (SEDF, 2012a). Segundo este documento, o CID possui como objetivo geral

\begin{abstract}
Oportunizar aos alunos da Rede Pública de Ensino do Distrito Federal o conhecimento técnico e tático de diferentes modalidades esportivas, buscando identificar diferentes aptidões e interesses e oportunizando a ampliação do processo de seleção e formação de futuros atletas (SEDF,2012a, p. 1).
\end{abstract}

Na configuração desta política, a OP incide diretamente sobre sua concepção teórico/filosófica, abrangência, forma de acesso e permanência, avaliação, monitoramento, controle e gestão.

Para além da OP, que orienta esses relevantes indicadores da política - mas, na questão pedagógica demonstra fragilidade conforme debateremos adiante - o Projeto estabelece relações com outras políticas desenvolvidas e/ou previstas no âmbito da SEDF presentes no atual PPA. Uma delas é a Gestão Democrática (Lei Nº 4.751 de 07/02/2012), que repercute questões como gestão local, controle social democrático e financiamento do Projeto, pois se trata de uma legislação que aproxima a gestão escolar de sua comunidade. Isso na prática possibilita que o Projeto CID seja inserido em questões e demandas da rotina escolar: integrar o Projeto Político-Pedagógico da escola, descentralizar as demandas do CID relacionadas a infraestrutura e material de consumo, por exemplo, além de ampliar a participação social e controle democrático.

Outra política importante, essa no âmbito educacional, é o PPP Carlos Mota lançado em 2012, que compreende o CID como instrumento para a emancipação humana, dentro de uma perspectiva de educação integral (SEDF, 2012b). Esta proposta pedagógica reverbera atenção especial a Educação Física escolar e a cultura corporal, conceito onde se insere esta prática que também é educativa, o esporte:

Assim, ancorada numa intervenção da corporeidade, do movimento humano e do respeito aos valores regionais, a Educação Física escolar reúne condições de atuar em todas as etapas e modalidades da educação básica do Distrito Federal. Como componente curricular, apresenta-se neste milênio com alguns desafios, entre eles, a articulação da cultura corporal com demandas que se desenvolvem nas múltiplas dimensões da vida - social, econômica, afetiva, cognitiva etc. Nessa perspectiva, existem temas que 
perpassam todo o conhecimento que deve ser desenvolvido nas aulas de Educação Física: corpo e estética; esportivização; espetacularização e megaeventos esportivos; ludicidade; lazer. (SEDF, 2012b, p. 57)

As iniciativas previstas no PPP Carlos Mota para o esporte educacional anunciam uma compreensão de "construção de valores e atitudes capazes de gerar uma transformação positiva na realidade social" (SEDF, 2012b, p. 49) que perpassa as diferentes etapas e modalidades da educação básica. Nesse sentido, prevê ações que incidem diretamente sobre a oferta do esporte educacional aos estudantes da rede pública de ensino, tais como:

- Ampliar o atendimento aos estudantes da rede pública de ensino, por meio do $\mathrm{CIEF}^{76}$, para atividades de iniciação e aperfeiçoamento desportivo.

- Aumentar a participação dos estudantes da rede pública de ensino nos Jogos Escolares do Distrito Federal e nas Olimpíadas Escolares Nacionais.

- Reorganizar as Orientações Pedagógicas dos Centros de Iniciação Desportivas, a fim de fomentar o Desporto Educacional (SEDF, 2012b,p. 59).

Não somente no Projeto Político Pedagógico institucional, mas também na proposta curricular institucional denominada Currículo em Movimento (SEDF, 2013), o esporte educacional se faz presente como uma das possibilidades de educação para a cidadania. Este documento ressalta a participação do esporte como uma atividade educativa e curricular, e destaca sua presença em uma perspectiva de educação integral. Essa educação integral proposta pelo Currículo em Movimento preconiza a não-diferenciação deste elemento da cultura humana, somadas a outras atividades como o lazer, a cultura, arte, educomunicação, educação ambiental, educação digital, entre outras de um conjunto de atividades que fazem parte de um projeto curricular integrado, significativo e prazeroso com vistas ao "pleno desenvolvimento das potencialidades humanas" (SEDF, 2014a, p.28).

\footnotetext{
${ }^{76}$ Centro Integrado de Educação Física, escola de natureza especial no âmbito do SEDF que oferta apenas atividades vinculadas à Educação Física regular, Educação Física no ensino integral e oficinas esportivas para a comunidade escolar, denominados "Projetos Especiais". Não há em seu PPP menção sobre a presença do CID em suas dependências. Fonte: PPP / CIEF 2014-2016. Disponível em http://sumtec.se.df.gov.br/sistemas/ppp/wp-content/uploads/2015/03/PPP-CIEF.pdf. $03 / 08 / 2015$

Acesso:
} 
Dessa forma, ao desenvolver em 2014 um Projeto Piloto que implementa a educação em tempo integral denominado Projeto Cidade Escola Candanga: Educação Integral77 (SEDF, 2014b) o CID é indicado como uma das intervenções pedagógicas possíveis em Educação Física e cultura corporal. O Projeto Cidade Escola Candanga, por sua vez, afirma claramente que o CID corresponde a uma atividade curricular complementar, não substituindo as aulas de Educação Física regulares, cuja intenção pedagógica se volta para o desenvolvimento da "totalidade humana" (SEDF, 2014b, p.46), enquanto o CID caracteriza-se por uma atividade complementar de aprendizagem esportiva, ora caracterizado por atividade singular da cultura corporal.

Cada polo do Centro de Iniciação Desportiva - CID atenderá os diversos estudantes das Escolas da CRE-Brazlândia. O CID caracteriza-se como espaço-tempo de vivência de uma única manifestação da cultura corporal (futebol, capoeira, voleibol, etc.) de forma aprofundada. (SEDF, 2014b, p. 47)

Pode-se depreender que há no Projeto Cidade Escola Candanga: Educação Integral de 2014, amparada pelo Currículo em Movimento uma preocupação com a relevância do viés educacional do esporte e seu protagonismo na proposta de educação integral, assim como a importância deste conhecimento se inserir no Projeto Político Pedagógico das unidades educacionais. Essa inclusão, elencada como possibilidade neste contexto já acontece de forma institucional, conforme demonstrado nas declarações de diferentes Gestores Locais e professores entrevistados, a exemplo do Professor 2:

Inclusive, nós somos integrados ao Projeto Político Pedagógico da escola a
partir desse ano, e a gente, no momento, conta muito com o que a escola
pode prover para a gente. [...] nós vamos ter que fazer parte das reuniões e
fazer aquela parte realmente da comunidade escolar, mostrando como o CID
está inserido, quais os valores que serão trabalhados aqui dentro do CID. [...]
Junto com os alunos e como que isso pode ser voltado para a formação
integral do aluno. (PROFESSOR 2)

Já no âmbito do financiamento, uma relevante política que repercutiu de forma decisiva no CID a partir de 2013 foi o Programa de Descentralização Administrativa e

77 O Projeto Cidade Escola Candanga: Educação Integral fora um projeto piloto desenvolvido na CRE de Brazlândia que inseriu a educação em tempo integral em 21 escolas da educação básica nesta RA do Distrito Federal no ano de 2014. 
Financeira $(\mathrm{PDAF})^{78}$, o qual estabeleceu a quantia de $\mathrm{R} \$ 24.000,00$ para cada Unidade Escolar que apresentassem um ou mais pólos de CID em sua Unidade. Isso representa em termo de magnitude um investimento de $\mathrm{R} \$ 2.000,00$ por mês/anualmente para cada UE financiar os pólos de CID em suas dependências. Essa verba, segundo a portaria que estabelece os valores e o direcionamento dos gastos, deveria ser destinada a aquisição de materiais esportivos (materiais de custeio) e contratação de serviços necessários ao desenvolvimento das ações previstas no Projeto CID válidas para o exercício de 2013.

Diante desse espectro conceitual, normativo e institucional do CID no interior das políticas esportivas no Brasil e no Distrito Federal percebemos que a trilha histórica das políticas de esporte educacional, é percebida com frequência a presença dos termos "talentos na área esportiva", assim como a preocupação e encaminhamento para um Programa de esporte de rendimento. Isso sinaliza o esvaziamento do sentido educacional emancipatório que o esporte pode vir a possibilitar, fortalecendo outra lógica inserida no esporte em ambiente escolar e nas políticas esportivas: a que toma o esporte na escola como base do esporte de rendimento. Esse mesmo pavimento se apresenta no marco normativo e conceitual do Projeto CID, lógica iminente das políticas esportivas educacionais já discutida neste trabalho.

Entretanto, seguindo a trilha deixada pelo método do materialismo históricodialético, percebemos no Projeto CID um caráter contraditório em sua materialidade, tomando como referências algumas ações que sinalizam uma democratização da política tal como ocorrido em 2012, quando pela primeira vez foi feito um processo seletivo regulamentado para acesso à docência do CID, minimizando possíveis traços de clientelismo no acesso e ampliação do Projeto. Da mesma forma, é anunciada em documentos institucionais relevantes ligados à pauta educacional a possibilidade de atuação deste Projeto em um viés crítico, com uma compreensão de historicidade em uma perspectiva - ainda que superficial e incipiente - de emancipação humana.

Outrossim, ainda que houvesse uma descontinuidade no ano de 2014, como verificaremos adiante, a criação de um mecanismo de financiamento como o PDAF abre possibilidades democráticas sobre o CID como ampliação do controle social. Essas ações representaram uma possibilidade para que tal Projeto fosse cada vez

${ }^{78}$ Portaria $N^{\circ} 71$ de 09 de abril de 2013, que em seu caput "Fixa os valores a serem descentralizados às Unidades Escolares e Coordenações Regionais de Ensino no âmbito do Programa de Descentralização Administrativa e Financeira - PDAF - para o exercício 2013 (...)". 
mais normatizado e the possibilitou um status crescente de política pública com segurança normativa e institucional tanto para seus beneficiários quanto para seus trabalhadores.

Para compreendermos essa contradição buscaremos no próximo capítulo uma aproximação mais íntima à materialidade desta política através da análise das entrevistas de seus atores, tomando como referência os indicadores de análise propostos para esta pesquisa. Neste esforço para compreender a totalidade do Projeto CID, analisaremos a política com base nos referenciais segundo as pistas deixadas por Boschetti (2009) para compreender se, e em que medida, o direito constitucional ao esporte educacional está sendo garantido através desta política com base na garantia de direitos de cidadania. 


\section{Capítulo 4 - Discutindo o Projeto CID}

\begin{abstract}
O que precisa ser confrontado e alterado fundamentalmente é todo o sistema de internalização, com todas as suas dimensões visíveis e ocultas. Romper com a lógica do capital na área de educação equivale, portanto, a substituir as forças onipresentes e profundamente enraizadas de internalização mistificadora por uma alternativa concreta abrangente.

(MÉZARÓS, 2008, p. 47)
\end{abstract}

A proposta de análise de políticas públicas sugerida por Boschetti (2009) ${ }^{79}$ aponta que esta deve considerar sus características históricas, pautadas pelas condições que compõe as múltiplas determinações do fenômeno, permitindo dessa forma uma análise em sua totalidade.

A investigação sob o enfoque do método dialético proposto por Marx consiste, precisamente, em situar e compreender os fenômenos sociais em seu complexo e contraditório processo do produção e reprodução, determinados por múltiplas causas e inseridos na perspectiva da totalidade[...] Na verdade, os fatos expressam um conhecimento da realidade se são compreendidos como fatos de um todo dialético, isto é, determinados e determinantes desse todo, de modo que não podem ser entendidos como fatos isolados. (BOSCHETTI, 2009, p. 2/3)

Nesse sentido, Boschetti (2009) percebe que é fundamental ter em vista, ao se analisar uma política, as dimensões históricas, econômicas e políticas onde essa política está inserida, de forma a serem compreendidas como partes de um todo profundamente articulado. Esse movimento foi feito nos capítulos anteriores para que pudéssemos reconhecer o Projeto CID como um produto histórico das políticas de esporte e esporte educacional que têm assumido um viés focalizado e com discurso mistificado e utilitarista. O desenvolvimento dessas políticas, contou com a parca participação popular e de correntes progressistas em sua concepção, avaliação e controle, o que favorece fortemente o esporte de rendimento, privilegiando o espectro

79 Disponível em http://www.cressrn.org.br/files/arquivos/V6W3K9PDvT66jNs6Ne91.pdf. Acesso: 16/09/2015. 
econômico e classista daqueles que conduzem o esporte institucionalizado. São estes interesses que têm predominado na concepção e implementação das políticas esportivas no Brasil e no DF.

Em uma proposta de análise do CID, portanto, esses fatores precisaram ser conhecidos e debatidos para que esta política fosse compreendida em sua totalidade. De tal forma, é possível avaliar se ela cumpre o papel de democratizar o acesso ao esporte na perspectiva de atendimento a uma necessidade básica dos seres humanos e também, como uma política educacional, contribui para a emancipação humana em oposição ao reprodutivismo utilitarista a qual o esporte educacional tem se vinculado. Em tempo, a proposta crítica de análise de Boschetti (2009) abarca esses fatores, sugerindo aspectos que permitem delinear alguns elementos empíricos desta política.

Esses aspectos, que segundo a autora também podem ser compreendidos como planos de análise, possibilitam atribuir sentido aos indicadores presentes em sua materialidade. Ao incorporar na análise esses seus aspectos, é possível revelar o caráter contraditório entre as normas e a materialização da política, mediando os determinantes estruturais que formam a política com as forças sociopolíticas que atuam tanto na sua formulação quanto execução. Esta proposta nos auxiliará a compreender a experiência atual do Projeto CID a partir de seu sentido histórico, de suas correlações com os determinantes estruturais em seu desenvolvimento e as contradições inerentes deste processo.

$\mathrm{Na}$ intenção de organizar a análise do Projeto CID enquanto política de esporte educacional, utilizamos nesta pesquisa os aspectos propostos por Boschetti (2009) tal como são descritos no Quadro 4 a seguir: 
Quadro 4 - Aspectos e indicadores de análise segundo o Método Crítico de Análise de políticas sociais de Boschetti ${ }^{80}$

\begin{tabular}{|c|c|}
\hline & ASPECTOS \\
\hline \multicolumn{2}{|c|}{ Configuração e Abrangência dos Direitos e Benefícios } \\
\hline $\begin{array}{l}\text { INDICA- } \\
\text { DORES }\end{array}$ & $\begin{array}{c}\text { Tipo e natureza dos benefícios } \\
\text { Abrangência } \\
\text { Critérios de acesso e permanência } \\
\text { Formas e mecanismo de articulação e/ou vinculação }\end{array}$ \\
\hline \multicolumn{2}{|r|}{ Financiamento e Gasto } \\
\hline $\begin{array}{l}\text { INDICA- } \\
\text { DORES }\end{array}$ & $\begin{array}{l}\text { Fontes do financiamento } \\
\text { Direccão dos gastos } \\
\text { Magnitude dos gastos }\end{array}$ \\
\hline \multicolumn{2}{|r|}{ Gestão e Controle Social } \\
\hline $\begin{array}{l}\text { INDICA- } \\
\text { DORES }\end{array}$ & $\begin{array}{l}\text { Relação entre as esferas governamentais } \\
\text { Relação entre Estado e sociedade } \\
\text { Participação e Controle Social Democrático }\end{array}$ \\
\hline
\end{tabular}

Sob a luz do referencial teórico do materialismo histórico dialético cabe ressaltar, de acordo com Paulo Netto (2011), que as categorias do objeto de análise em uma pesquisa são compreendidas e elaboradas através do esforço de abstração, ou procedimentos intelectivos do pesquisador no contato com a materialidade, por meio da reprodução teórica do concreto do objeto: "o conhecimento concreto do objeto é o conhecimento de suas múltiplas determinações - tanto mais se reproduzem as determinações de um objeto, tanto mais o pensamento reproduz a sua riqueza (concreção) real" (PAULO NETTO, 2011, p. 45).

Paulo Netto (2011) afirma que no decorrer do processo investigativo, segundo o método de $M a r x^{81}$, o ponto de partida é o mesmo ponto de chegada (o concreto do objeto) e no contato com a materialidade e posteriormente na análise dos dados

\footnotetext{
${ }^{80}$ Boschetti, 2009.

81 Segundo Paulo Netto (2011) Marx não se ocupou durante a vida em desenvolver um método de pesquisa ou método científico, mas sim de compreender a sociedade burguesa. Nisto, desenvolveu ao longo de sua trajetória um método próprio de investigação decorrente de uma profunda elaboração teórica, pois sua legítima preocupação era determinar o "método adequado para o conhecimento veraz, verdadeiro da realidade social" (p. 19). Este é o método que conhecemos como materialismo históricodialético.
} 
chega-se a "conceitos" e "abstrações" que permitem conhecer singularidades e determinações que podem ser compreendidas como categorias. Essas, com suas complexidades e particularidades, permitem ao pesquisador compreender o "complexo de complexos" que determinam a totalidade do objeto.

Nesta compreensão, Boschetti (2009) assevera que sua proposta de análise não se detém somente a esses aspectos e indicadores pré-elaborados, ou seja, não considera que estes se esgotam na variedade e possibilidades de análise face às especificidades de cada política. Com essa possibilidade, portanto, de compreender a política que nos propomos analisar enxergando diversos aspectos presentes nos indicadores identificados em seu concreto (sua materialidade), foi possível realizar um movimento de aproximações e intersecções entre os aspectos e indicadores propostos pela autora, agregando outros que foram abstraídos (no sentido marxiano ${ }^{82}$ ) do concreto que se coadunam com a perspectiva educacional, universo onde o Projeto CID se insere.

No interior dos aspectos Configuração e Abrangência dos Direitos e Benefícios (ou apenas Configuração e Abrangência) proposto pela autora, um indicador foi especialmente identificado e direcionado para a questão da concepção pedagógica adotada no Projeto. Este indicador fora apanhado no contato com a materialidade da política através de seu delineamento, para além das indicações de Boschetti (2009) em sua proposta original de análise. A gestão de pessoal também se revelou importante indicador no aspecto Gestão e Controle Social para compreensão da política. Outros indicadores foram subtraídos da proposta original por entendermos que a abordagem adotada permite centrar esforços no âmbito especifico da Política analisada, direcionada ao esporte educacional, que, diferentemente das demais políticas sociais esportivas desenvolvidas no Distrito Federal é executada, controlada e avaliada pela Secretaria de Estado de Educação do DF.

Ao analisar os resultados da pesquisa, cabe ressaltar que eles foram organizados segundo seus Aspectos, que serão demonstrados em consonância com a proposta de Boschetti (2009), conforme veremos a seguir. Embora decidiu-se em não esquematizar a discussão por indicadores por entendermos, conforme já elucidado, que há uma perspectiva de totalidade e complementaridade entre estes,

82 Id., ibid. 
sua apresentação por Aspectos propõe-se a oferecer, nas palavras da própria autora, uma visualização mais nítida e didática da política através deste plano de análise.

\title{
I - Configuração e abrangência
}

Para situar a análise desta política, há de se destacar inicialmente o protagonismo de um marco normativo que direciona as ações do CID: sua Orientação Pedagógica. Conforme verificamos no capítulo anterior, e confirmado nas entrevistas junto a seus atores, a OP faz sombra em todos os aspectos de análise deste trabalho, constitui-se não somente em seu marco normativo principal, mas também conceitual. $E$, em seu bojo, possui uma série de contradições e incongruências que merecem considerações, pois puderam ser verificadas no chão da quadra, o lócus dessa política.

O Projeto CID é uma política de esporte escolar, pois se enquadra claramente nesta categoria prevista pelo Decreto $N^{\circ} 7.984$ de $2013^{83}$, o qual institui as normas gerais sobre o desporto no Brasil.

\begin{abstract}
O desporto educacional pode constituir-se em: [...]
II - esporte escolar, praticado pelos estudantes com talento esportivo no ambiente escolar, visando à formação cidadã, referenciado nos princípios do desenvolvimento esportivo e do desenvolvimento do espírito esportivo, podendo contribuir para ampliar as potencialidades para a prática do esporte de rendimento e promoção da saúde.
\end{abstract}

$\S 2$ - $\mathrm{O}$ esporte escolar pode ser praticado em competições, eventos, programas de formação, treinamento, complementação educacional, integração cívica e cidadã, realizados por: [...]

II - instituições de educação de qualquer nível. (BRASIL, 2013)

Durante a investigação foi observado que ele assim é reconhecido por seus professores e gestores, atores fundamentais na materialização desta política. Já os

\footnotetext{
83 Vide discussão estabelecida no capítulo 2, a qual compreende esta é uma subdivisão abstrata. Este raciocínio dá sentido à afirmação de Marx, que entende que as teorias (as ideias) devem ser a reprodução do movimento real: da realidade se extrai a teoria, e não o contrário (da teoria não se constrói uma realidade). (PAULO NETTO, 2011)
} 
objetivos anunciados para o CID segundo sua OP, dizem respeito à formação esportiva, preparação para competições, uso da competição como instrumento pedagógico, fomento das atividades desportivas. Sua justificação teórica baseia-se na literatura que versa sobre o desenvolvimento e aquisição de capacidades/habilidade físico-motoras. Seu referencial teórico, portanto, é de viés desenvolvimentista (CASTELLANI FILHO, 1999; SAMPAIO, 2013). Desta forma, como aventou Castellani Filho (1999), esta concepção se constituiria em uma proposta de ensino sistematizada, mas não-propositiva, pois define princípios de uma prática de ensino em Educação Física, mas não define princípios metodológicos para tal. Segundo Sampaio (2013), o precursor desta concepção de ensino em Educação Física, Go Tani (1988, apud SAMPAIO, 2013) coloca como seu protagonista único o movimento humano. O autor afirma que as postulações de Tani deram amparo para outras propostas de ensino e concepções teóricas especialmente no campo da Educação Física escolar nas décadas de 1980 em diante, que conforme verificamos, consubstanciaram-se no arcabouço teórico do CID, por exemplo.

Esse arcabouço se evidencia em diversas entrevistas com os professores, cuja denominação "treino" surge com frequência em suas falas e intervenções: "a princípio o CID é voltado para o treinamento técnico do aluno. E a gente o denomina alunoatleta." (PROFESSOR 2); "Cada CID trabalha uma modalidade específica com o objetivo de, se possível, descoberta de talentos [...] Se o esporte escolar tem se mantido dentro da Secretaria de Educação é graças ao CID" (PROFESSOR 4). Isso contradiz à função anunciada para o CID em sua OP que seria "Oferecer aos alunos o caráter de formação esportiva crítica" (SEDF, 2012a. p. 4), outrora concomitante a outros objetivos de caráter técnico-desportivo e preparatório para competições.

Segundo Coletivo de Autores (1992), a formação crítica perpassa o reconhecimento da sociedade capitalista como uma sociedade de classes, onde se implicam uma série de limites e possibilidades que são traçados por esse modelo de organização social. Uma intervenção crítica em um ato educativo, aqui representado pelo esporte educacional, seria aquela que contextualizasse as possibilidades emancipatórias do sujeito educando através do processo educativo, cuja matriz conceitual a OP não sinaliza ou menciona.

A prática da cultura corporal, dentre elas o esporte, assume um caráter crítico ou transformador quando expressa "sentido/significado onde se interpenetram, 
dialeticamente, a intencionalidade/objetivos do homem e as intenções/objetivos da sociedade" (COLETIVO DE AUTORES, 1992, p. 62). Portanto, a contradição que estabelece o caráter dialético do ato educativo pode ser identificada quando, segundo os autores, o docente tem a intencionalidade do ensino da técnica, e o estudante/aprendiz tem a intencionalidade lúdica, ou vice-versa.

$\mathrm{Na}$ configuração dessa política o desenvolvimento das aptidões técnicodesportivas e motoras se revela ação intencional e finalística, portanto, ainda segundo Coletivo de Autores (1992), benéfica ao projeto histórico de uma classe social específica, a burguesa, pois, dessa forma, abdica da consciência de classe e suas possibilidades emancipatórias. Isso repercute no CID como a não-configuração de uma ação educativa emancipatória, pois não apenas anuncia, mas referencia-se no modelo da pirâmide esportiva e da concepção desenvolvimentista, tal como propôs, por exemplo, o Diagnóstico da Educação Física e dos Desportos no Brasil, de 1971. É mister destacar que alguns dos seus critérios de acesso são a indicação de alunos talentosos pelo professor de Educação Física ou a seleção direta pelo professor do CID (SEDF, 2012a).

Os beneficiários do Projeto são os estudantes matriculados na rede pública, até o encerramento do Ensino Médio, ou seja, estudantes da Educação Básica. Atualmente, segundo o órgão central de controle do CID, a CEFDESC, existem aproximadamente 9.600 (nove mil e seiscentos) alunos matriculados no Projeto ${ }^{84}$, no universo de 470.000 (quatrocentos e setenta mil) matrículas na rede pública de ensino ${ }^{85}$. Em geral, a matrícula no CID é aberta não apenas paras os estudantes matriculados nas Unidades Escolares (UE) onde se encontram os pólos do CID, mas também de escolas nas regiões vizinhas, ou seja, possibilita aos estudantes da rede pública de ensino que se avizinhem aos pólos usufruírem da modalidade de sua opção. Ademais, percebemos que para os critérios de acesso e permanência não apenas basta o estudante ser matriculado na rede pública de ensino como preconiza a OP, uma perspectiva que vislumbra uma "universalidade" ao menos nos limites da SEDF.

\footnotetext{
${ }^{84}$ Fonte: CEFDESC. Em setembro/2015

85 Fonte: Censo Escolar 2014 da Rede Pública do Distrito Federal. Disponível em: http://www.cre.se.df.gov.br/ascom/documentos/censo/2014/turmas matr\%C3\%ADculas 2014.pdf. Acesso: 05/07/2015
} 
Os critérios de acesso e permanência também atendem ao selecionamento esportivo pautado na identificação de talentos, habilidades físicas e técnicas compatíveis, idade e sexo, critérios esses sugeridos pela lógica competitivista balisada pelos Jogos Escolares da Juventude. Para corroborar esse raciocínio, basta perceber que as atividades da cultura corporal ofertadas pelo CID, com algumas exceções, são concomitantes as modalidades de competição nos Jogos da Juventude, conforme demonstra o Quadro 05:

Quadro 5: Modalidades do CID versus Modalidades dos Jogos da Juventude

\begin{tabular}{|c|c|c|}
\hline Modalidades & Projeto CID & $\begin{array}{c}\text { Jogos Escolares da } \\
\text { Juventude }\end{array}$ \\
\hline Futsal & $\mathrm{X}$ & $\mathrm{X}$ \\
\hline Basquetebol & $\mathrm{X}$ & $\mathrm{X}$ \\
\hline Voleibol & $\mathrm{X}$ & $\mathrm{X}$ \\
\hline Handebol & $\mathrm{X}$ & - \\
\hline Futebol de campo & $\mathrm{X}$ & $\mathrm{X}$ \\
\hline Xadrez & - & $\mathrm{X}$ \\
\hline Ciclismo & $\mathrm{X}$ & - \\
\hline Taekwondo & $\mathrm{X}$ & $\mathrm{X}$ \\
\hline Tênis de mesa & $\mathrm{X}$ & $\mathrm{X}$ \\
\hline Judô & $\mathrm{X}$ & $\mathrm{X}$ \\
\hline Atletismo & $\mathrm{X}$ & $\mathrm{X}$ \\
\hline Ginástica rítmica & $\mathrm{X}$ & - \\
\hline Ginastica artística & $\mathrm{X}$ & $\mathrm{X}$ \\
\hline Natação & $\mathrm{X}$ & - \\
\hline Capoeira & $\mathrm{X}$ & $\mathrm{X}$ \\
\hline Luta Olímpica & $\mathrm{X}$ & - \\
\hline Karatê & $\mathrm{X}$ & $\mathrm{X}$ \\
\hline Badminton & - & $\mathrm{X}$ \\
\hline Vôlei de praia & & \\
\hline
\end{tabular}

Fontes: CEFDESC (abril/2015); Comitê Olímpico Brasileiro ${ }^{86}$

Isto reforça a ideia de que o CID se aproxima mais da reprodução de um modelo esportivo ditado pela lógica do esporte de alto rendimento do que uma formação crítica. Alguns pólos do CID se permitem ampliar o atendimento na faixa etária prevista pela OP ( 5 anos, mas neste caso iniciando a partir de 4 anos de idade, segundo o Professor 3) e de população atendida (comunidade circunvizinha ao pólo, independente de matrícula na rede pública para essa faixa etária) em virtude de sua

86 Disponível em: http://www.cob.org.br/pt/jogos-escolares/modalidades-jogos-escolares. Acesso: 01/09/2015. 
especificidade: a excelência competitiva, como é o caso do pólo onde atua o Professor 3:

\begin{abstract}
Como o pólo aqui é um pouco mais especializado a gente tem representação até em níveis internacionais. Dentro do pólo já chegou em um nível que a gente tem competições nacionais, então, a gente faz a organização de viagem, hospedagem, toda essa logística de competições fora, no Brasil ou no exterior, é feita pelos professores. Isso acaba também sendo uma incumbência dos professores ligados diretamente a modalidade. (PROFESSOR 3)
\end{abstract}

A unidade do CID em questão se estabeleceu como um pólo de referência não somente na SEDF, mas em todo o Distrito Federal para uma dada modalidade olímpica, estabelecendo vínculos com políticas esportivas federais e com a Federação local e a Confederação do esporte. Tal unidade se permite estabelecer, por si só, parcerias com entidades representativas de sua modalidade:

Nós temos ligações junto a Federação do esporte local - a Federação Brasiliense - bem como com a Confederação Brasileira de Ginástica. Inclusive, em algumas vezes contamos com o apoio, em decorrência dos resultados obtidos nacionalmente, junto ao Ministério do Esporte, a gente conseguiu celebrar alguns convênios que contribuiu para melhoria do espaço [...] através do CID [daquele pólo] e do resultado dos meninos que o representam. [...] Teve uma articulação junto a Federação local. Não foi a nível de CEFDESC, mas com a Federação Local e a Confederação também. (PROFESSOR 3)

Em tempo: o Projeto CID possibilita o acesso a crianças a partir de 5 anos de idade em algumas de suas modalidades ofertadas (Ginástica Artística e Ginástica Rítmica, segundo a OP), mas, para as demais, observa-se uma sincronia suas atividades e a lógica organizacional imposta pelos Jogos da Juventude, ou ainda, pela possibilidade de treinamento e lapidação de talentos. Dessa forma, ela se distancia da universalização deste direito constitucional já que o Projeto CID, como uma política pública (ou seja, sua razão de existir deveria ser a garantia de direitos) inclina-se para a focalização, primeiramente porque as atividades da cultura corporal não estão universalizadas através da Educação Física escolar na rede pública de ensino ${ }^{87}$, e

87 Existe um Projeto em andamento na SEDF que oferece Educação Física escolar para as séries iniciais do Ensino Fundamental, o Projeto Educação com Movimento. Mas, segundo a CEFDESC, aproximadamente 100 professores(as) de Educação Física atuam em um universo de 
ainda porque segundo os relatos, as atividades do CID privilegiam estudantes do ensino fundamental e médio, idades pertinentes à lógica das categorias esportivas organizadas pelo COB e pelo COI (guardiões da lógica do olimpismo) para os Jogos da Juventude. Quando existe essa ampliação da faixa etária de atendimento, a partir da infância, ela obedece a critérios nítidos de iniciação desportiva, conforme apontou o Professor 3.

Contraditoriamente a essa realidade, há uma preocupação anunciada com a formação socioeducativa dos estudantes beneficiados. Essa possibilidade certamente abriu-se a partir da inserção do Projeto CID nas ações previstas no último PPA em seu Programa da Educação Básica, com o debate no interior da gestão pública da educação e sua preocupação em articular o CID com as políticas educacionais implementadas no período. O Gestor Central 2 nos explica como se deu este processo:

\begin{abstract}
O CID é um Projeto importante porque historicamente foi um espaço em que as crianças e adolescentes da rede pública de ensino - e a maioria delas não tem como pagar uma atividade de lazer - pudessem ampliar o seu repertório da cultura corporal. O CID tem essa perspectiva! Então, atender quem? Os estudantes da rede pública de ensino. É uma política pública importante porque diversifica a prática corporal, é uma atividade escolar, é uma atividade complementar e que atualmente está totalmente dentro do currículo. A educação integral discutida nesse Governo, nesse quadriênio, não preza o aumento do tempo do estudante na escola. Visa ofertar também ao estudante a sua integralidade, a possibilidade de vivenciar a sua integralidade, a sua condição cognitiva, psicomotora, afetivo-emocional, cultural [...] como atividade que fortalece a perspectiva de integralidade da escola, da Escola Candanga - essa nossa escola que vem hoje nessa perspectiva de integralidade. (GESTOR CENTRAL 2)
\end{abstract}

Essa atenção especial à perspectiva educativa, trazendo à discussão o esporte como elemento da cultura corporal sinaliza um despertar para que em suas atividades o CID se ocupe não apenas em formar atletas, inserindo de forma acrítica os estudantes na cultura do esporte competitivo. A cultura esportiva no interior da escola (instituição com quem o CID possui relação visceral), sem uma reflexão crítica e uma intervenção contumaz dos agentes que o materializam, alienam dos estudantes a possibilidade de vivenciarem um processo realmente educativo, dando subsídios para que reconheçam este elemento de sua cultura como uma riqueza que eles podem

aproximadamente seis mil e setecentas turmas em tal nível de ensino, ou seja, o atendimento a essa faixa da população escolar ainda encontra-se distante de sua universalização. 
operar de acordo com suas possibilidades e intencionalidades voltado para sua emancipação e formação para a cidadania.

Nas entrevistas com os professores, percebeu-se em alguns dos discursos uma preocupação com a perspectiva socioeducativa dos estudantes, ou seja, para além do treinamento físico-técnico dos usuários desta política:

\begin{abstract}
Eu sinto presente a nossa função como professores do CID que é a questão da educação. Como esse garoto vai ser educado, essa garota vai ser educada para viver em sociedade? Para respeitar que alguém passe na frente dele em uma fila e aquilo não seja uma ofensa que tenha que terminar em desafio de punhos e chutes. Então, o que está envolvido ali? [...] A questão da própria língua, a quantidade desses alunos que não conseguem ter uma fala coerente. Sabe? Que tem erros de concordância... E aí, essa função da gente, no treino, de poder observar isso e saber que "esse garoto tem essa dificuldade!" (PROFESSOR 1)
\end{abstract}

Também há a preocupação de alguns gestores locais com a educação dos estudantes que se encontram sob a tutela do ambiente escolar. Há o relato do Gestor Local 2 que, preocupado em oferecer uma atividade de Educação Física para seus alunos, já que sua escola não oferece a disciplina na grade curricular por sediar apenas as séries iniciais do Ensino Fundamental, estabelece uma parceria com a professora do CID para que esta ofereça suas atividades no horário da grade curricular aos alunos de maior idade ( $5^{\circ}$ ano). Também há o acordo para que a professora do CID auxilie na elaboração de gincanas e festividades que envolvam jogos e brincadeiras.

É um acordo que nós temos no sentido de acreditarmos que nossos alunos precisam de uma atividade física, e como nós não temos um profissional de Educação Física [sic] na escola, que a gente gostaria de ter, procuramos contemplar os alunos desta maneira, fazendo essa atividade de vôlei, porque o ideal seria uma aula de Educação Física, mas nós não temos. [na escola não existe o Projeto Educação com Movimento]. (GESTOR LOCAL 2)

A respeito desta relação do CID com a rotina da escola, houve uma intervenção deliberada por parte do órgão de controle central, a CEFDESC no período do último PPA no sentido de estimular que o CID fosse inserido nos Projetos Políticos Pedagógicos das escolas. Isso representou uma possibilidade para que o CID pudesse vislumbrar-se uma ação educativa através do esporte e não simplesmente uma ação de esporte adaptado ao contexto educacional (lógica que a categoria 
esporte escolar embute). Nesse sentido, o docente que atua no Projeto assuma um maior compromisso com o cotidiano escolar e com a UE, como debater questões pertinentes ao fazer educativo em uma perspectiva inter e multidisciplinar, conforme pondera o Gestor Central 2:

A Coordenação Pedagógica talvez seja o maior espaço de fortalecimento
pedagógico do Projeto. O professor é obrigado a coordenar uma vez na
escola, com o grupo da escola - porque ele não é um professor de clube, é
um professor de escola, professor da Secretaria de Estado da Educação.
Portanto, ele tem que ter acesso ao que vem sendo debatido na sala de aula
no que se refere à Educação Física curricular; ele tem que entender a lógica
da escola para o Projeto não se distanciar dessa dimensão pedagógica.
Então, a Coordenação Pedagógica talvez seja o maior instrumento, o espaço
mais importante de fortalecimento e acompanhamento da dimensão
pedagógica do Projeto. (GESTOR CENTRAL 2)

Tal relevância pedagógica também fora reconhecida pelos demais Gestores Centrais e Locais entrevistados, muitos deles com reconhecimento de que esta articulação auxilia na manutenção e controle desta atividade no interior da escola, conforme abordaremos adiante no Aspecto Gestão e Controle Social. E, para os docentes, auxiliou em diversos aspectos como a segurança jurídico-institucional e financiamento de suas atividades, que também serão discutidos adiante. Embora os professores não tenham relatado grandes avanços desta iniciativa repercutidos em sua intervenção pedagógica, o relato do Professor 2 exprime bem o sentimento entorno desta articulação CID / PPP da escola:

Primeiramente, a questão de pertencimento à escola. O aluno do CID vai começar a ver que existe um local físico em que ele participa, em que ele vai ter que ser ativo. Ele vai ter que ser transformador, ele vai ser crítico, ele vai ter que cobrar as melhorias da sua sala, vai ter que cobrar a melhoria do seu colega. Ele vai fiscalizar essa questão dos valores - se os valores estão sendo trabalhados, sendo aplicados [...] O aluno vai ter que responder o que seriam os valores trabalhados não só dentro da escola, mas ali dentro do CID também, como ele está executando isso fora da escola. Se realmente está levando os valores da escola, os valores do CID, o valor da modalidade Judô para fora da escola. Então, dentro do PPP, essa questão do CID estar inserido é importantíssimo, principalmente - volto a falar na palavra inicial com a questão do pertencimento. O aluno vai começar a entender que a escola vai fazer parte do dia a dia dele, fora daquele horário cognitivo, daquele horário mais voltado para disciplina, para a matéria [...] Eu acho que a palavra-chave do PPP com o CID chama-se pertencimento. (PROFESSOR 2) 
Apesar deste discurso muito presente nas falas dos docentes, percebemos que a questão educativa, não é delineada com clareza no espectro institucional do Projeto. Há de se estabelecer um diálogo efetivo com as concepções de educação onde o esporte educacional deve estar inserido no âmbito das proposições políticopedagógicas da SEDF. Do acervo documental mais recente onde o CID se apresenta, - Projeto Escola Cidade Candanga é o que traz com maior profundidade o reconhecimento do esporte como elemento da cultura corporal introduzido pelo PPP Carlos Mota e pelo Currículo em Movimento. Esse conceito anuncia em sua matriz a possibilidade de emancipação humana, iluminando em seu horizonte a satisfação de uma necessidade humana básica para sua emancipação, conforme pondera Pereira (2008b) ou a garantia de direitos de cidadania tal como anunciados por Coutinho (1999).

Entretanto, nas matrizes conceituais e normativas do próprio CID, essa discussão ainda não está presente, conforme se verificou no discurso dos docentes do Projeto. O que predomina ainda é o caráter da competição escolar e a formação de valores necessários à própria prática esportiva, talvez se aproximando do discurso perlocucional apontado por Flausino e Mascarenhas (2012).

Para ilustrar essa hegemonia da lógica competitiva, para além dos muros escolares é regra geral o CID estabelecer articulações com outros pólos através de torneios (como o torneiro Intercid) ou instituições que praticam ou organizam atividades esportivas afetas a cada modalidade desenvolvida nos pólos como jogos amistosos, festivais, competições ou treinamentos. Essas instituições podem ser outras unidades do CID, unidades educacionais ou instituições privadas como o SESC, por exemplo.

A gente não pode ficar apenas com as aulas, não é, porque chega um ponto em que os alunos questionam "para que ele vem treinar"?! Então, fora as atividades do CID [as aulas], nós participamos de várias competições: os jogos INTERCIDS, dos jogos do SESC - são eventos esportivos fora! [...] Hoje, o SESC, nos oferece gratuidade para os CIDs, para as escolas públicas. Nós conseguimos não pagar para participar. [...] Fora os jogos INTERCIDS, eventualmente, em contato com os outros CIDs da própria modalidade, a gente organiza encontros também. Ou no meu polo ou no polo de outro CID, a gente se encontra para fazer torneio entre os alunos, para fazer integração entre os alunos. (PROFESSOR 4)

Também fora mencionado a articulação, ainda que indireta, com os Jogos Escolares do Distrito Federal. Os estudantes matriculados nos CIDs se capacitariam nas aulas (através do treinamento oferecido) para atuarem por sua escola. 
Com exceção de um professor, os demais não perceberam alguma influência direta nos megaeventos esportivos no Brasil, tanto a Copa do Mundo FIFA 2014 quanto as Olimpíadas Rio 2016 na ampliação ou alcance de seu CID. Quanto ao primeiro, todos os professores julgam não ter influência alguma, pois atuam em uma modalidade distinta ao futebol, já em relação ao segundo acreditam que com a proximidade do evento haverá uma procura ou um maior interesse junto a modalidade que lecionam. Já o Professor 4, um dos maiores entusiastas da formação esportiva do Projeto CID, tem uma percepção diferente, acredita que seus alunos têm a percepção e a perspectiva de avançarem no esporte profissional, e as olimpíadas Rio 2016 podem constituir-se em uma vitrine nesse sentido:

\begin{abstract}
Com relação aos Jogos Olímpicos o que eu posso falar com relação ao polo: hoje os meus alunos, aqueles que estão se desenvolvendo melhor, não ficam esperando só aqui o CID para saberem mais da modalidade do tênis de mesa. Eles acompanham os jogos, o que que está acontecendo no Youtube, no Facebook, nos Jogos Mundiais. Eles já sabem! Eles vão atrás! [...] Nesse ponto talvez os Jogos Olímpicos tragam uma influência maior porque eles vão "estar de olho!" É uma influência sim porque eles estão vendo e eu já ouço alguns alunos que dizem: "Professor, um dia eu vou estar ali!" "Eu quero estar ali!" Para os alunos, é esse sonho de realmente, um dia, se tornar um atleta olímpico, de se consagrar, trazer uma medalha para casa. Alguns alunos chegam a até sonhar que se possível, quem sabe, viver do esporte. Alguns alunos comentam isso, eles falam isso! (PROFESSOR 4)
\end{abstract}

À exceção do movimento percebido por esse professor em suas aulas, esse questionamento trouxe a reflexão se os demais pólos caminham no sentido contrário às postulações de Mascarenhas (2012) e Bracht e Almeida (2013) quando estes analisam a possibilidade de forte influência dos megaeventos na Educação Física escolar, ou se o próprio CID caminha no sentido contrário à Educação Física escolar, afirmando-se como um espaço de formação de talentos e aperfeiçoamento desportivo e despojando-se da formação humana com base em princípios socioeducativos.

Ao se perceber a dubiedade de interpretações concedidas à prática pedagógica do CID, especialmente no caráter raso de sua formação socioeducativa, afere-se que a intenção de fortalecimento do viés educacional nos últimos quatro anos - sob a influência do PPA - necessita de uma maior regulação e direcionamento para que atravesse um processo histórico favorável a uma mudança efetiva. Percebe-se uma falta de clareza no interior de seus marcos institucionais e conceituais, em especial a OP, cujo resultado se verifica no discurso contraditório de diversos professores 
entrevistados, os quais, com exceção do professor 3 que declarou a perspectiva clara de treinamento e aperfeiçoamento esportivo com viés de alto rendimento, declaram enxergar a perspectiva educacional, ainda que se vinculem a termos como "treinamento" e "competição" de maneira unânime. O discurso do Professor 2 ilustra essa contradição presente entre os valores esportivos trabalhados pelo CID e os valores da formação educativa presentes em uma aula de Educação Física, por exemplo.

\begin{abstract}
A gente tem uma dificuldade de atribuições do esporte na escola. É treino ou é aula? Até onde o professor de Educação Física pode levar o seu aluno? Eu acho que isso permeia a cabeça de todo professor de Educação Física quando ele está dentro da sala de aula! Eu posso conduzir essa aula quando eu vejo que uma determinada turma tem um grupo de pessoas que consegue ir mais e além daquela situação, eu posso puxar um pouco mais, eu posso cobrar um pouco de performance. Ou sairia totalmente daquela situação da aula que é aquela questão do cognitivo, do psicomotor, do afetivo, do emocional que tem que ser todo trabalhado em prol, não é? De um trabalho mais quantitativo, mais específico, um trabalho mais de performance! Então, eu vejo, que a gente ficou sem essa identidade. O CID apareceu, mas não consegue ainda mostrar para o aluno esse outro lado, é a continuação do trabalho dele da Educação Física: "Olha! Você é bom naquela modalidade de Educação Física! Procura o CID!" E vai completar, e vai terminar e, depois do CID, o que vai acontecer para ele e, eu acho que, talvez, seja um mea culpa dos profissionais de Educação Física [sic]. A gente não está conseguindo trazer isso para o aluno! [...] Eu acho que isso era muito claro na época do militar porque a visão da Educação Física na escola também era outra. (PROFESSOR 2).
\end{abstract}

Isso deve ser discutido em relação à OP do CID, que permite se adotar em sala de aula diferentes lógicas e vieses de ensino, mas sem deixar de lado a perspectiva do selecionamento esportivo. É preciso que se haja discussão e fortalecimento das ações que permitam, como almejou o Gestor Central 2, que o CID hipertrofie ações que atinjam o âmago de cada intervenção pedagógica, permitindo que as diretrizes pedagógicas do Projeto sejam melhor discutidas, disseminadas e apreendidas. Caso contrário, esta política se perderá dentre as demais políticas esportivas do DF como apenas mais uma que fortalece a perspectiva engendrada pela lógica da pirâmide esportiva e da focalização das políticas. Conclui-se que muitos dos avanços do CID experimentados nos últimos anos em comparação com sua experiência histórica, especialmente no âmbito da perspectiva educacional, aquela que verdadeiramente possibilitaria a garantia de direitos de cidadania, ainda não foram claramente 
regulamentadas ou definidas em seus marcos normativos, especialmente seu principal, a Orientação Pedagógica do CID.

Entretanto, há de se ressaltar que iniciativas fundamentais como a inclusão do CID nos PPPs das unidades educacionais possibilitou a esta política uma garantia não apenas de seu sentido educacional, mas também em outros aspectos como a questão financeira e de gestão, possibilizando que se amenize iniciativas pessoalistas dos docentes e possibilitando um maior estreitamento de suas atividades às possibilidades educativas do esporte educacional, nem tanto atrelados à lógica do esporte competitivo, mas apontadas para uma perspectiva de formação para cidadania e emancipação humana. Essa repercussão será discutida a seguir.

\title{
II - Financiamento e gasto
}

As entrevistas confirmam que o financiamento através do PDAF representou um enorme salto qualitativo para as atividades do CID, sendo direcionado para compra de material esportivo de qualidade, financiamento para participação em campeonatos - inscrições, traslados, uniformes, conforme nos sinaliza o Professor 1 , com 11 anos de experiência no CID:

\begin{abstract}
Nós conseguimos o PDAF e ele, então, pôde ser usado na compra de uniforme de jogo - e aí, é uma coisa que a gente cuida com o maior cuidado; então, ele vai durar durante alguns anos ainda [...] $\mathrm{E}$ conseguimos algumas bolas - isso depois de nove anos de CID, foi a primeira vez que a gente conseguiu material assim! A gente já tinha recebido alguns materiais anteriormente, mas eram materiais sem condições de trabalho para o CID. (PROFESSOR 1)
\end{abstract}

Os demais professores e gestores locais das UEs onde o CID foi contemplado com essa verba também ratificam que os gastos foram direcionados para aquisição de bens de consumo e serviços respectivos à manutenção das atividades do CID. A relevância deste financiamento para o desenvolvimento com qualidade das atividades do Projeto CID é descrita pelo Gestor Local 3: 
Eu acompanho o CID já há alguns anos e eu tenho percebido que tem participado mais de campeonatos. Quando o PDAF deu a oportunidade de ter uma verba própria para o CID ficou muito mais fácil levar os alunos para os campeonatos porque a gente começou a receber verba do transporte. Antes a gente precisava colocar os alunos no carro da gente, no carro do professor para levar até a competição. Então a partir do momento que o aluno tem esse transporte facilitou a participação em vários campeonatos, inclusive como você pode perceber a gente tem alguns troféus e medalhas que recebemos por participar porque temos o transporte. Isso foi muito importante [...] e a gente percebe que o material, a partir do momento que podemos comprar com o PDAF, não recebendo da Secretaria, se pode comprar de mais qualidade, o que favorece o treino do aluno. (GESTOR LOCAL $3^{88}$ )

Algumas escolas, em virtude de critérios administrativos não tiveram acesso ao PDAF do CID. Essas questões, previstas na Portaria que regulamenta o PDAF ${ }^{89}$, preveem desde inadimplência (irregularidades nas prestações de contas anteriores) ou inauguração recente da UE ou Programa/Projeto. Dentre as escolas pesquisadas, duas se enquadraram nessas questões, mas, graças à inclusão do CID no PPP da escola, puderam realizar investimentos em seus respectivos pólos. Foi o caso da escola do Gestor Local 4, onde a própria UE construiu um espaço para a prática do CID com a verba do PDAF e financia os materiais necessários para sua prática mesas, redes, bolas e raquetes. Não obstante, contribui para esse investimento e essa visão diferenciada o fato do diretor da escola, seu gestor principal, ser professor de Educação Física, de acordo com o entrevistado. Dessa forma, o CID que funciona na escola articula-se também com o cotidiano escolar:

\begin{abstract}
A estrutura física é um espaço que anteriormente não havia, isso é uma inovação, o espaço fora construído esse ano [junho/2015]. Havia um espaço que é um pátio da escola onde eles faziam atividade, mas como estava tendo problema [sic] porque na hora do intervalo os alunos que chegavam para lanchar interferiam no Projeto, então, nós fizemos aquele lá atrás justamente para tentar diminuir alguns problemas que existiam como os alunos que adentravam a aula [do CID], apesar de que os alunos que não queriam lanchar participavam também [com anuência do professor]. (GESTOR LOCAL 4)
\end{abstract}

Portanto, a inclusão do CID nos PPPs das escolas possibilitou não apenas a inserção desta política no caminho de uma perspectiva educacional mais nítida, mas

\footnotetext{
88 O comentário do Gestor Local 3 ressalta a perspectiva do CID como atividade escolar que tem ênfase no treinamento esportivo e competição, inclusive diante os gestores das Unidades Educacionais onde eles desempenham suas atividades.

89 Portaria No 134 de 14/09/2012.
} 
também uma segurança institucional diante seu financiamento, já que a normatização do PDAF prevê que seus recursos sejam destinados à execução do PPP da escola90.

O depoimento do Professor 5 é um dos mais enfáticos na importância que representou o financiamento do PDAF para o CID, dado sua experiência de 10 anos no Projeto:

\begin{abstract}
Na questão da qualidade, do ano de 2013 para 2015, após o recebimento da verba foi excepcional, foi um divisor de águas o recebimento daquela verba em questão de qualidade, pelo menos nós aqui da Ceilândia tivemos um material de qualidade, participamos de competições onde pudemos pagar a inscrição, tivemos a oportunidade de pagar transporte, o nosso aluno foi tratado com muita dignidade e respeito, foi um excelente ano. E continuamos com muita luta em 2014 usando todo o material que a gente adquiriu (PROFESSOR 5).
\end{abstract}

Essa iniciativa efetivamente representou um avanço na questão do financiamento em relação à experiência histórica do Projeto, pois este sempre foi incerto para as demandas necessárias à prática pedagógica e a manutenção das unidades do CID. Dado essa incerteza e descontinuidade, os professores do Projeto CID na maioria das vezes trabalharam alimentados por sua iniciativa própria conforme percebeu Quirino et. al. (2012) nos anos que antecederam o PDAF:

\begin{abstract}
No que tange ao financiamento, no início dos anos oitenta eram destinadas verbas orçamentárias aos CID, mas com o passar dos anos, o projeto foi abandonado. Desde o final dos anos Noventa, o projeto não possui recursos próprios, sendo mantido graças ao esforço de professores que acabam por obter material de trabalho para a prática desportiva junto à Secretaria de Educação ou, mais raramente, graças a alguns poucos patrocínios. (QUIRINO et. al., 2012, p. 3)
\end{abstract}

Esses autores verificaram que o Projeto CID sempre possuiu em sua história dificuldades na questão do financiamento. O mesmo deixou de existir a partir da década de 1990, e os professores das modalidades esportivas sustentavam as atividades com seus próprios recursos, juntamente com alguns patrocínios esporádicos e incertos conseguidos com o próprio esforço dos docentes (QUIRINO et. al., 2012). A ausência desta política nas ações governamentais previstas no PPA anterior, o qual previa pseudo-ações de esporte educacional envoltos em um viés

90 Id., ibid., Art. $8^{\circ}$. 
focalista e no discurso mistificador ajudam a corroborar as informações trazidas por Quirino et. al. (2012).

Essa afirmação se confirma ainda nos relatos dos Professores e Gestores Locais, em especial aqueles com maior experiência no Projeto, que relatam seu histórico de parcerias, doações, auxílio mútuo e solidariedade com as atividades do CID.

\begin{abstract}
O que vem além disso [o PDAF] é uma luta tremenda! Nesses últimos dois, três anos, a gente tem visto algumas "luzinhas" no final do túnel que nos animam bastante! Mas, apenas, nesses últimos anos. [...] A gente já tinha recebido alguns materiais anteriormente [de doação], mas eram materiais sem condições de trabalho para o CID. Recebemos algumas bolas, mas elas não tinham condições de uso [...] pensando em treinamento desportivo. $E$ vivia muito de doações até aquele momento [anteriormente ao PDAF]. Para ir competir, tem que reunir as famílias, cada um contribui com um pouquinho e, invariavelmente, sai muito do bolso da gente como professor [...] Você paga uma inscrição em um torneio, leva os garotos até o torneio. Você vai ter que dar um "lanchinho" para ele, então, passa no supermercado, pega uma coisa um pouco mais saudável - que faz parte do que a gente propõe a eles de educação também desde o primeiro dia de aula - identificar melhor os alimentos, "não é"?! [...] Então, nesses últimos anos, o sustento do CID foi todo ou provido por mim ou por alguma doação que a gente conseguia. (PROFESSOR 1)
\end{abstract}

Isso fornece uma pista de como o CID não somente esteve, mas ainda permanece sobre a iniciativa voluntarista desses professores em face à incerteza do financiamento próprio, quando este não está disponível, tendo em vista que a escola, por si só, não pode financiar o Projeto (já que possui outras prioridades urgentes). Dessa forma, quando esgotada a verba do PDAF, o CID retorna às suas origens:

\footnotetext{
A gente conta com a comunidade em algumas situações, com o recurso interno da própria escola, e vou ser muito sincera, às vezes a professora chega a tirar do bolso dela para arcar - pagando, mesmo! - ônibus pra levar menino porque quando não têm, muitas vezes ela arca, às vezes a gente faz alguma atividade pra ajuda-la, mas nem sempre a escola tem, então às vezes ela arca, conversa com os pais pra eles pagarem ao menos a passagem pra eles irem para os torneios, ou a inscrição, quando não tem recurso. Porque quando tem recurso do PDAF, a gente paga com este recurso, já pagamos quando veio em 2013. Então, todas as inscrições eram pagas com aquele recurso, o transporte era pago com aquele recurso. Mas o recurso acabou, então a gente se vira como pode. (GESTOR LOCAL 2)

Então, a gente se mantém, praticamente... para transporte, qualquer coisa, no caso, eu mesma banco. Eu não tenho nenhuma ajuda, nenhuma parceria e, infelizmente, essa é a realidade. (PROFESSOR 5)
}

Essas iniciativas acabam por tal maneira configurando-se personalistas, revelando uma desresponsabilização do Estado nesta política. Essa cultura não 
somente repercute na qualidade da oferta ao estudante, mas acaba por penalizar o docente que nele trabalha.

Não apenas a personalização do financiamento é perniciosa ao desenvolvimento do Projeto. Neves (2004) coloca em cheque sua perspectiva democrática quando este se oculta ao efetivo controle social democrático, de maneira que pessoaliza uma iniciativa que deve ser de caráter público. Já Raichelis (1998, apud BERING e BOSCHETTI, 2011), afirma que dois componentes são fundamentais para a consolidação da democracia: a ampliação dos fóruns de decisão política, incorporando novos protagonistas e articulando entendimentos que fortaleçam as decisões coletivas, e o fortalecimento da cultura pública, aquela que caminha na contramão da cultura privatista, de apropriação do público pelo privado. Isso se demostrou na história do CID, conforme verificado.

Essa cultura da desresponsabilização ou da personalização de ações de financiamento ainda que (parcialmente) superada pela presença do PDAF se depara com as dificuldades cotidianas e com as circunstâncias políticas enfrentadas não apenas pelo CID, mas por toda a pasta da educação pública em virtude de eventuais contingenciamentos de despesas. Para 2015, o Gestor Central 3 anuncia que, ainda como o corte de gastos nos últimos dois anos, foi possível despender financiamento para o CID através de seu PDAF- ainda que reduzida em $83 \%$ diante ao primeiro PDAF - mas, que pode dar um fôlego nas atividades para este ano.

\footnotetext{
Neste ano [2015] nós tivemos nosso orçamento praticamente todo contingenciado, então nós conseguimos descentralizar um recurso para o CID com muito custo, não por má vontade ou por fragilidade da política, mas pela escassez do recurso. Nós conseguimos descentralizar o recurso só da manutenção, do material de consumo do professor em forma de PDAF. Um valor de $\mathrm{R} \$$ 4.000. (GESTOR CENTRAL 3)
}

Tal debate não apenas repercute no aspecto da Gestão e Controle Social Democrático, mas conforme sinalizou Boschetti (2009), interpenetra e dialoga com essa análise. No intuito de não se perder a noção de totalidade da política, essa ação será discutida e aprofundada logo a seguir. 


\section{Gestão e Controle Social}

Este aspecto de análise representa, em nosso entendimento, um dos gargalos históricos no aspecto da democratização do Projeto CID, mas, ao mesmo tempo, uma de suas inovações em relação à sua expansão e manutenção de suas atividades.

O Projeto CID se trata de uma iniciativa que é controlada, avaliada e fomentada pelo poder executivo do Distrito Federal através da SEDF, possuindo em suas fileiras um quadro de servidores públicos, regidos em seu trabalho pela Lei Complementar $\mathrm{N}^{\circ}$ $840^{91}$ e demais legislações específicas da SEDF, ou seja, trabalhadores com estabilidade no emprego e segurança jurídico-institucional conquistada historicamente pelo coletivo de servidores públicos do Distrito Federal. Sua entidade representativa é o Sindicato dos Professores do DF, entidade classista da mais alta representatividade dentre as demais no Distrito Federal contando em suas fileiras com aproximadamente trinta e quatro mil filiados ${ }^{92}$.

O CID não estabelece relações com entidades privadas ou do terceiro setor no que diz respeito à gestão de pessoal. No âmbito do Estado, o CID estabelece relações com outras esferas no sentido do usufruto de espaços públicos para a prática de suas atividades, conforme declaram os Gestores (Centrais e Locais) e Professores. Essas relações têm maior volume com a Secretaria de Esportes, já que segundo declararam os Gestores Centrais, algumas modalidades do CID (regular e Paralímpico) ocupam espaços cedidos por dois Centros Olímpicos, especialmente das cidades de Santa Maria e São Sebastião (GESTOR CENTRAL 1). Essa relação é regida por Termo de Cooperação celebrado pela SEDF e órgãos conveniados. Alguns Professores e Gestores Locais relataram ainda uma espécie de "parceria", que se assemelha mais a compreensão de "concessão" por parte das Administrações Regionais por se utilizarem da quadra poliesportiva da comunidade (caso de um CID que funciona na UE do Gestor Local 3), ou cessão de transporte para participação de torneios (PROFESSOR 1).

\footnotetext{
${ }^{91}$ De 23/12/2011, dispõe sobre o regime jurídicos dos servidores públicos civis do Distrito Federal, das autarquias e das fundações públicas distritais.

${ }_{92}$ Fonte: Sinpro-DF
} 
Em relação a gestão de pessoal, é fundamental destacar que todos os atores dessa política entrevistados ressaltaram a relevância da inserção dos trabalhadores docentes do Projeto no chamado "concurso de remanejamento". Esse "concurso de remanejamento" corresponde ao processo seletivo interno da SEDF que estabelece critérios para a lotação e exercício funcional do servidor, sua mudança (remanejamento) ou classificação por tempo de serviço ${ }^{93}$. Segundo o Gestor Central 1, desde 2012 ocorria uma seleção interna para exercício no CID elaborada pela CEFDESC com critérios técnicos de acesso, que a para o ano letivo de 2014 somouse ao remanejamento.

Em 2012, pela primeira vez, foi feito um processo seletivo, [...] foi estabelecido alguns critérios, dentre eles formação profissional, experiência, currículo, e nesse processo se ranqueavam os professores e a partir daí se chamava os professores que passaram no processo seletivo para abertura. No ano de 2014, pela primeira vez o CID foi incluído no processo de remanejamento. (GESTOR CENTRAL 1)

Anteriormente, o acesso aos professores para atuação no CID correspondia a iniciativa subjetiva e interesse particular do docente em abrir um pólo de CID, que após análise do interesse da administração do Projeto concedia tal oportunidade ao professor. Tal iniciativa ainda se encontra registrada em sua OP.

Como parte do processo seletivo, o professor deverá apresentar um projeto de implantação do CID a CRE/GREB ${ }^{94}$ que encaminhará a Coordenação de Educação Física e Desporto Escolar CEFDESC/Gerência de Desporto Escolar-GEDESC [...] Após a implantação do CID, o professor deverá cumprir as exigências descritas abaixo para que a sua permanência seja efetivada [...] Ao final de cada ano letivo estas exigências serão analisadas pela CEFDESC/GEDESC, em conjunto com a coordenação do programa nas CRE para sua permanência ou não no ano letivo seguinte. (SEDF, 2012a, p. 11/12)

Tal registro repercute a história de acesso à docência no Projeto. Essa forma de acesso foi vivenciada pelos professores mais antigos entrevistados pela pesquisa: "Há 11 anos atrás [...] eu fiz a apresentação desse Projeto com a escola, na época, o Setor Leste [...] o projeto foi aceito e então pude iniciar o trabalho" (PROFESSOR 1).

\footnotetext{
93 Portaria da SEDF N ${ }^{\circ} 219$ de 14/10/2014.

${ }^{94}$ Gerência Regional de Educação Básica, órgão de natureza pedagógica que controla no âmbito das CREs as questões pedagógicas locais.
} 
É mister destacar que o Projeto CID, conforme já verificamos, foi instituído legalmente em 2004 e regulamentado em 2005. A iniciativa desta lei fora da exdeputada Eurides Brito (PMDB), sancionada posteriormente pelo ex-governador Joaquim Roriz (PMDB) em 2005. Tais sujeitos, pelo seu histórico de atitudes controversas no âmbito da política local ${ }^{95}$, deixam um rastro político que dá margem a compreensão de práticas clientelistas. O clientelismo, segundo Neves (2005) impõe

[...] obstáculos ao processo de construção democrática, em especial nos contextos em que a prática clientelista é forte tendência, pois ocorre aí um processo de forte despolitização da participação. Nesse aspecto é que acreditamos que a participação pode se caracterizar como assistencialista e negociada no fortalecimento de uma cultura menos democrática e voltada para interesses individuais, onde o clientelismo tem forte presença nos diferentes contextos locais. (NEVES, 2005, P. 214)

Atitudes que possibilitariam o uso desta política em uma perspectiva clientelista, no sentido da alocação de recursos humanos, foi minimizada através da ação recente de realizar um concurso seletivo e inclusão na estratégia de remanejamento da SEDF, conforme nos sinaliza o Gestor Central 2: E enquanto ao professor, nós [a CEFDESC] já estamos desde 2013 com um
processo seletivo. Antes disso, havia uma indicação. Aí sim, o gestor tinha
poder de indicar uma pessoa que tinha mais prioridade, que tivesse mais
proximidade com determinada modalidade. Podia até chegar a indicar
pessoas que ele conhecia [...] Então, com um processo que aconteceu esse
ano - que é o remanejamento, ou seja, a abertura de carências nas próprias
regionais, e com o processo seletivo, o professor tem que passar por um
processo democrático! Com um processo de remanejamento, você tem a
democratização do acesso ao CID. (GESTOR CENTRAL 2)

Assegurar o acesso ao trabalho pelo concurso de remanejamento permitiu ao
CID uma transparência maior no processo de sua expansão, controle e monitoramento. A inclusão do CID no concurso de remanejamento permitiu ainda a

95 Joaquim Roriz ocupou o mandato de governador do DF em quatro oportunidades (três eleitos e um
por indicação), foi eleito senador em 2006 e renunciou ao mandato em 2007 para escapar da cassação
do mandato por ter sido flagrado pela Polícia Civil do DF, Ministério Público e Receita Federal, segundo
Liáo Jr. (2013) no escândalo de corrupção denominado Operação Aquarela. Segundo o autor, Roriz
teve sua candidatura a mais um mandato de governador do Distrito Federal impugnada pela "Lei da
Ficha Limpa" em 2010. Já a ex-deputada Eurides ocupou por diversas oportunidades o cargo de
Secretária de Educação durante os mandatos de Joaquim Roriz. Eleita para o mantado de deputada
Distrital diversas vezes, teve seu mandato cassado em 2010 por recebimento de propina no caso
conhecido como Mensalão do DEM. Fontes: www.wikipedia.org; www.cl.df.gov.br Acesso: $05 / 09 / 2015$ 
inclusão de novos atores respectivos a estas ações. Os Gestores Locais assumem a responsabilidade de controle da vida funcional dos docentes do Projeto, pois estes respondem por sua frequência na UE. As CREs agora respondem por sediar a lotação funcional do docente, que caso deseje, pode remanejar-se para outra Regional ou unidade do CID de seu interesse sem perder direitos.

Essa possibilidade foi elogiada por todos os atores entrevistados: os gestores locais por obterem esse maior controle e integração com os estudantes, os docentes e a comunidade circunvizinha à escolar (já que os alunos pertencem àquela escola e as escolas vizinhas). Os docentes pela segurança institucional e trabalhista. A gestão central pela corresponsabilização e descentralização dessa gestão no Projeto e também pela possibilidade mais imediata de inserção do CID na rotina escolar.

\begin{abstract}
Nosso papel tem sido de sensibilizar e motivar a equipe das Coordenações Regionais de Ensino para a abertura de pólos, para identificar as condições, locais de abertura de pólos. Eles apresentam a proposta de abertura de novos pólos para nós, aqui analisamos aspectos como a disponibilidade de pessoal e aprovamos ou não a abertura desses pólos de acordo com essas condições, tentamos de todas as maneiras possíveis viabilizar, propondo e articulando as parcerias possíveis. Mas, cabe a cada Regional de Ensino identificar as condições e propor a abertura dos pólos. (GESTOR CENTRAL $3)$.
\end{abstract}

Não obstante, a inclusão desses novos atores e mecanismos institucionais como o PDAF e a inclusão no PPP das escolas, por exemplo, permitiu ampliar o controle democrático sob diversos outros aspectos. Pelos mecanismos institucionais de controle, o financiamento e direcionamento dos gastos passam pelas mãos do Conselho Escolar ${ }^{96}$, pois com a alocação de recursos diretamente remetido para a escola, há necessidade de discussão dos gastos e investimentos por essa instituição. Pela norma vigente, é implícito os mecanismos de controle democrático para as atividades escolares, pois toda a verba deve ser discutida e aprovada pelo Conselho e pela Assembleia Escolar.

\footnotetext{
96 Pela Lei de Gestão Democrática (Lei № 4.751/2012), cabe ao Conselho Escolar além de analisar, modificar e aprovar o plano de aplicação de recursos no âmbito das UEs, analisar e avaliar os Projetos elaborados no interior das escolas. É composto por todos os segmentos da comunidade escolar: pais, professores, equipe gestora, servidores administrativos e estudantes (quando maiores de 16 anos). Já a Assembleia Escolar é a instância deliberativa geral e ampliada que delibera sobre todas as questões administrativas, pedagógicas ou outras quaisquer submetidas pelo Conselho.
} 
A inserção do CID no Projeto Político Pedagógico das escolas também contribuiu em seu controle Social Democrático, pois este é um documento que orienta as ações pedagógicas da escola e deve ser elaborado com a participação de todas as instâncias previstas na Lei de Gestão Democrática. Portanto, permite descentralizar o controle sobre as questões pedagógicas do CID em relação à CEFDESC e adaptálas à rotina escolar, conforme já sinalizou anteriormente o Gestor Local 2 em relação a presença do CID na grade escolar dos estudantes e o Gestor Local 4 do uso pelos estudantes do espaço e equipamento do CID em sua UE. Ainda se verificou uma articulação com as aulas de Educação Física regular, conforme sinalizou o Gestor Local 3 ao citar a inserção do Professor do CID na rotina escolar. Essas ações repercutem positivamente tanto no cotidiano escolar quanto no financiamento do CID:

\footnotetext{
Participam na coordenação [pedagógica], participam das atividades de jogos escolares internos da escola, tanto na elaboração, apitando jogos, colaboram dentro da escola. [...] Principalmente porque a gente precisa utilizar a verba, e pra utiliza-la com o CID ele tem que estar no PPP, por que a verba [do PDAF] é utilizada conforme as definições do PPP da escola (GESTOR LOCAL 3)
}

Essa contribuição engendrada pelos documentos que demarcam conceitualmente as políticas educacionais recentes tais como a Lei de Gestão Democrática, o PPP Carlos Mota, o Currículo em Movimento e o Projeto Cidade Escola Candanga (educação integral) possibilitaram ao CID não somente essa aproximação aos valores educacionais quanto uma segurança institucional aos trabalhadores do Projeto, ao financiamento direto às ações necessárias para o funcionamento do CID e a ampliação do Controle Social Democrático sobre o Projeto.

E, apesar destas iniciativas terem mudado a partir de 2012, conforme declarações dos sujeitos entrevistados, a OP continua em processo de reformulação e a não regulamentação desta ação impõe limites e estabelece contradições no bojo desta política, a exemplo do ocorrido no ano de 2014. Isso permitiu que não houvesse a destinação da verba do PDAF neste ano, fragilizando os avanços obtidos nos anos anteriores e deixando mais uma vez o Projeto à mercê da incerteza, conforme apontaram diversos professores e gestores locais do Projeto.

O financiamento direto para o CID através do PDAF está assegurado apenas para segundo semestre de 2015, conforme sinalizou o Gestor Central 3. E, conforme 
demonstra a experiência recente do CID apontada pelos sujeitos da pesquisa, somado à iniciativa pessoal de muitos de seus docentes, servirá para financia-lo até o novo aporte.

A cultura política que se apresentou na forma de organização do Projeto, somado ao incerto financiamento no decorrer de sua trajetória histórica (QUIRINO et. al., 2012) colocavam em suspeição seus princípios norteadores, o mero desenvolvimento de habilidades esportivas e capacidades físicas e técnicas que atendam a este fim. A ausência do sentido educativo-emancipatório, da articulação com a lógica escolar em suas Orientações Pedagógicas, se confrontadas ao modelo conceitual das políticas para o esporte educacional desde seu surgimento até sua experiência atual, somados aos fundamentos básicos de seu arcabouço teórico indicavam qual projeto histórico se colocava em vantagem no desenvolvimento desta política.

A experiência do controle democrático é um mecanismo que possibilita a socialização da política e a ampliação da democracia substantiva, aquela onde há a possibilidade de pleno desenvolvimento da cidadania, não apenas na perspectiva procedimental e formal. Os Conselhos participativos, segundo Behring e Boschetti (2011) têm "grandes potencialidades como arenas de negociação de propostas e ações que podem beneficiar milhares, milhões de pessoas e de aprofundamento da democracia" (IDEM, p. 178). A inserção do CID nessas novas arenas politicas permitem apontar um novo caminho mais democrático em sua trajetória atual.

A concepção de ações para consolidar essa perspectiva educativa no Projeto CID partiu, segundo demonstrado nas entrevistas, de iniciativa do próprio órgão de Controle central do CID. Essas concepções, que em virtude das circunstâncias históricas favoráveis a um projeto educacional progressista e democrático - quiçá até contra-hegemônico diante da lógica imposta em nível nacional (conforme verificamos nos capítulos anteriores) - se não consolidadas através de um marco normativo sólido para suas concepções pedagógicas correm o risco de esvair-se na guerra de posições presente na política de nossa contemporaneidade, especialmente após o avanço e recrudescimento do pensamento reacionário-conservador observado após o pleito eleitoral em $2014^{97}$.

\footnotetext{
${ }^{97}$ Nestas eleições, apesar do projeto reacionário-conservador ter sido derrotado no pleito nacional para o posto de comandante do Executivo, ele avançou no âmbito do poder Legislativo. No Distrito Federal, saiu vencedora uma coalisão entre o Partido Socialista Brasileiro e os partidos da frente conservadora nacional, através do movimento antipetista engendrado por essa força. Já o legislativo local seguiu o mesmo movimento do federal.
} 
Entendemos que não se pode dissociar a discussão da ampliação e consolidação dos direitos sociais sem considerar perspectiva do direito circunscrito à Política em questão, o financiamento e os indicadores de gestão e controle democrático das ações em forma de Política Pública que concernem tanto à formação humana (objeto da ação educativa) quanto da consolidação de direitos sociais (objeto da Política Pública). A consolidação de direitos é uma prática social revolucionária na esteira da luta do homem pela sua emancipação.

O Projeto CID, uma política com mais de três décadas de funcionamento, grande parte desta trajetória atrelada a perspectiva de esporte concebida ainda no período anterior a democratização, vive um momento histórico de redescoberta. Contudo, o desenvolvimento de todo projeto histórico é um processo recheado de contradições e conflitos, onde a política se apresenta não apenas em sua forma institucional como centro da atividade do Estado, conforme pondera Pereira (2008a) materializada em ações governamentais, mas como atividade de mediação entre interesses diferentes ou desiguais, cujos instrumentos são a coerção (com seus mecanismos de controle e regulação) e o consenso (a própria atividade política). É dessa forma que poderão se fortalecer a perspectiva contra-hegemônica do esporte educacional utilitário ao fortalecimento do esporte de alto rendimento, o qual estabelece para as políticas esportivas a perspectiva focalista, financeirista, e instrumental à lógica que não a democratização e consolidação de direitos. 


\title{
Considerações Finais
}

\begin{abstract}
Desconfiai do mais trivial, na aparência singelo. E examinai, sobretudo, o que parece habitual. Suplicamos expressamente: não aceiteis o que é de hábito como coisa natural, pois em tempo de desordem sangrenta, de confusão organizada, de arbitrariedade consciente, de humanidade desumanizada, nada deve parecer natural, nada deve parecer impossível de mudar. (BRECHT, s/d)
\end{abstract}

A experiência histórica do Projeto CID, diante daquilo que se apresenta em seu marco institucional, marco conceitual e sua materialidade, permite afirmar que ele ainda se encontra distante da consecução de direitos de cidadania, posto ainda não possuir um caráter de universalidade e equidade, (PEREIRA; STEIN, 2010). Após três décadas de funcionamento, foi possível constatar nesta pesquisa que, a exemplo de outras políticas de cunho social, seu sentido de seletividade e focalização prevaleceram em relação à perspectiva de garantia de direitos, para qual o esporte se apresenta perante a Carta Magna brasileira. Pereira e Stein (2010) relatam que o exercício dos direitos de cidadania através de políticas públicas se afirma a partir da perspectiva universalista, não-discriminatória e equânime.

O CID ainda se distancia da universalização de direitos, por uma série de questões observadas nesta pesquisa. Primeiramente, podemos citar a dinâmica das políticas esportivas no período pós-constitucionalização. Conforme verificamos, a normatização do esporte na alça dos direitos constitucionais decorre de um processo capitaneado por setores ligados ao esporte formal e institucionalizado, com parca participação popular (LINHALES, 1996). O período que corresponde à criação de suas legislações demarcatórias (as leis esportivas) ficou marcado pela liberalização e privatização. Somado a isso, a criação de um Ministério específico para o esporte já no século XXI deu sequência a este movimento: ao se aproximar das políticas sociais, o esporte movimentou a lógica da focalização, da mercantilização e fortaleceu a hegemonia do campo econômico e conservador do esporte. (VERONEZ, 2005; CASTELLANI FILHO, 2008; 2013; BUENO, 2008; LIÁO JR., 2013). 
Na esteira desse movimento, no Distrito Federal não aconteceu de forma diferente. Para o período proposto de nossa análise as políticas esportivas previstas no PPA correspondiam à lógica das políticas esportivas nacionais. Ainda que o CID no último PPA (2012-2015) tenha sido inscrito às políticas educacionais - o que permitiu uma diversidade de ações que o valorizassem - ainda se apresenta o senso comum esportivo que apanha essa política e as demais de esporte educacional sob o viés mistificador e utilitário.

A exemplo, a focalização desta política se configura através da seletividade de seus beneficiários no âmbito da SEDF, conforme verificamos, predominantemente estudantes cuja idade se aproxima das faixas etárias estipuladas pelas competições esportivas estudantis. Mas não apenas isso, a ausência da Educação Física em todas as séries da educação básica na rede pública de ensino impossibilita a universalidade do ensino da cultura corporal, dificultando a apropriação deste construto humano de forma crítica e histórica pelos sujeitos educandos nas diversas faixas etárias. Dessa forma, ao CID se dificulta a sistematização e materialização de propostas efetivamente críticas, reforçando a tendência ao viés mistificado e utilitário do esporte no processo educativo.

Já a mercantilização que identificamos não incorre na transferência de renda ou subsídios diretos aos beneficiários próprio das políticas monetaristas, conforme apontou Matias (2013). A cultura esportiva que tem como culminância o esporte de alto rendimento permite a criação de um mercado consumidor do esporte que repercute na comercialização de seus diversos produtos, gerando acúmulo para o setor econômico envolvido com o esporte enquanto mercadoria.

Certamente contribui para essa mistura o caráter intervencionista do esporte a partir do Estado, personagem que garante o desenvolvimento da ordem vigente nos diferentes aspectos de reprodução da vida social (econômico, cultural, espiritual) de forma predominante e perene através desta manifestação da cultura humana. Dessa forma, a lógica de organização neoliberal a qual as políticas estão subsumidas, amparada pela aura mistificadora e o discurso perlocucional construído ao redor do esporte (FLAUSINO; MASCARENHAS, 2012) tem repercutido no CID através de seus marcos conceituais e normativos.

Portanto, ao reproduzir em seu âmago a dinâmica engendrada pela construção do direito a esporte na sociedade brasileira, o CID esteve sujeito, tal como as políticas 
sociais, ao esvaziamento das ações que lhe possibilitariam a perspectiva da universalidade e da equidade (PEREIRA E STEIN, 2010). Seu amplo histórico de desresponsabilização quanto ao financiamento (QUIRINO et. al.,2012), somado a ações voluntaristas de seus professores para manter as atividades do Projeto no decorrer de sua experiência histórica, ainda em tempos de financiamento regulamentado (GESTOR LOCAL 2; PROFESSOR 5), permitem ao leitor desinformado compreender esta política pública como uma ação individual e voluntarista de docentes de Educação Física afetos à prática esportiva, mesmo que haja, contemporaneamente, um amplo espectro institucional que oferece segurança jurídica e democratize diversos aspectos do Projeto CID. O resultado da intervenção do Projeto tendeu a ser, por muito tempo, o que a subjetividade docente e as condições materiais de sua execução possibilitaram.

Através dos resultados obtidos, não há como concluir que a presença do CID nos PPPs das escolas tivesse força para problematizar ou superar a concepção pedagógica desenvolvimentista e a lógica da seletividade e competitividade presentes na prática do CID. A presença do(a) professor(a) nas coordenações pedagógicas de forma contínua e efetiva possibilitariam que essas questões ao menos fossem problematizadas e contemporizadas à discussões pedagógicas promovidas no ambiente escolar. Essas, atualmente, possuem um referencial teórico com a perspectiva crítica, conforme verificamos nos marcos conceituais mais recentes da SEDF. Em virtude da recente mudança política no Projeto CID, especialmente observada nas gestões que se encontram sob o planejamento do mais recente Plano Plurianual do DF (2012-2015), o órgão de controle central, a CEFDESC, ainda não possui dados que repercutam o resultado desta iniciativa (GESTOR CENTRAL 3).

Destarte, as ações pedagógicas presentes nos discursos docentes e dos Gestores Locais não apontam para uma atuação crítica do CID, mas sim de uma concepção reprodutivista do esporte educacional que vem sido mantida há décadas e dá suporte a ideia do discurso perlocucional sinalizado por Flausino e Mascarenhas (2012). Isso representa, no âmbito das políticas públicas, mais um entrave para que se consigne a ampliação de direitos de cidadania, da mesma forma, distancia a política do atendimento a uma necessidade básica.

Para que a aula do CID seja problematizada enquanto tempo/espaço pedagógico, há necessidade premente de formação dos professores afim de que 
estes compreendam o processo de educação para emancipação, indo além da educação funcional/utilitária através da lógica esportivista/reprodutivista. Essa formação certamente irá se reproduzir nos espaços educativos do CID, nas unidades educacionais através da interlocução com o tempo/espaço da escola e os atores que dela fazem parte, ampliando-se do ambiente escolar como espaço pedagógico e alcançando a possibilidade de um maior controle social com novos sujeitos através da comunidade escolar.

Para que isso ocorra, entendemos que o esporte, um satisfador das necessidades básicas do ser humano, há de ter nos espaços educativos uma perspectiva crítica e contextualizada para a transformação social e superação do modelo de produção e reprodução social que aliena os homens e precarizam o atendimento a suas necessidades básicas, conforme ponderou Matias (2014). Na intenção de superar esse cenário, a formação continuada dos professores do Projeto deve ir além da instrumentação nas modalidades esportivas.

Para que o CID vire esta página é necessário uma série de ações integradas. Inicialmente, tomar conhecimento desta dinâmica de pauperização e projetização das políticas (LIÁO JR., 2013), que é articulada pela “despolitização" das políticas esportivas $^{98}$. Ao tempo em que essas se alienam da discussão ampliada, crítica e consciente de seu papel emancipador, permite-se deixar levar pelo movimento que não somente reproduz, mas beneficia o grande capital com sua lógica neoliberal e mercantil das políticas sociais. Ao que parece, esse movimento foi o que contribuiu decisivamente na subdivisão triádica do esporte em seu processo de constitucionalização, cuja culminância foi a abertura das portas para sua liberalização.

Em seguida, ampliar a participação de diferentes sujeitos políticos e agentes históricos favoráveis à luta pelos interesses democráticos e populares através do

\footnotetext{
98 Cotta (1998) citando Cohen e Franco (1993) afirma que Projeto é a unidade mínima de destinação de recursos, que, por meio de um conjunto integrado de atividades, objetiva transformar uma parcela da realidade, de forma a suprir uma carência ou alterar uma situação-problema. Já Programa seria um conjunto de projetos que visam aos mesmos objetivos, os quais estabelecem prioridades da intervenção, identificam e ordenam os projetos, definindo o âmbito institucional e alocação dos recursos a serem utilizados (ibid.). Segundo os autores, o Projeto está contido no Programa, que por sua vez abarca diversos Projetos em sua constituição. Disponível em http://repositorio.enap.gov.br/handle/1/1634. Acesso em 22/09/2015. Ou seja, a transformação das políticas públicas em "Projetos" Ihe confere um status perecível, finito, que não contribui ao debate dos direitos de cidadania, despolitizando-os. De tal forma, como CID enquadra-se no status de "Projeto" desde sua inauguração, isso certamente contribuiu para sua histórica insegurança jurídica-institucional, comprovada pelos quadros observados de "desresponsabilização", pessoalismos e possível clientelismo observados na pesquisa.
} 
esporte (LIÁO JR., 2013). Castellani Filho (2007) postula que o acesso a este bem da cultura humana deve considerar a inclusão, como uma possibilidade de prática livre e despojada da lógica que o compreende como base de um sistema de alto rendimento (a pirâmide esportiva), a fruição de sua possibilidade- espetáculo e, sobretudo, "o conhecimento do significado e de seu lugar em nossa cultura" (CASTELLANI FILHO, 2007, p. 5). O CID, pelo que identificamos na pesquisa, hoje não se configura em uma ação educativa com propósitos emancipatórios, portanto, instrumento para a emancipação humana e a conquista de direitos de cidadania. Os atores envolvidos nesta política, especialmente aqueles que lhe dão materialidade - os professores e professoras - ainda se encontram vinculados a uma perspectiva educacional rasa, envoltos nas "abstrações" que o discurso mistificador do esporte carrega: "educar para viver em sociedade" (PROFESSOR 1), "eles têm o sonho de viver do esporte" (PROFESSOR 4); "o CID é a continuação do trabalho esportivo da Educação Física" (PROFESSOR 2).

É fundamental considerar que o CID se configura em uma possibilidade dos estudantes para aperfeiçoarem-se no esporte. Mas, a formação de futuros atletas conforme anuncia a OP do CID e o discurso de alguns de seus professores está prejudicada pela falta de perspectiva através de políticas públicas para continuação da prática esportiva competitiva após o aluno de CID terminar sua escolarização, conforme discorre o Professor 2:

\begin{abstract}
A gente não está conseguindo demonstrar, deixar claro para ele: "Olha! Se você for bom, tem uma continuidade aqui! Se continuar daqui, pode ser achado por algum clube! Se chegar em num clube, pode ter uma vivência profissional!" [...] Hoje, eu não vejo o clube oferecer uma gama de atividades como oferecia antigamente, salvo exceções aqui fora de Brasília: o Pinheiros, o Minas, alguns outros assim! [...] eu ainda não consigo ver o aluno buscando - CID para dar uma continuidade, buscando um clube para continuar um CID e buscando a sua vida profissional de atleta por causa da Educação Física, por causa do CID. (PROFESSOR 2)
\end{abstract}

Nesse sentido, a falta de um Sistema Esportivo integrado que una as possibilidades anunciadas em seus marcos normativos/conceituais não possibilita ao CID, de fato, tornar-se aquilo que ele se propõe em seus pressupostos iniciais: oportunizar a ampliação e seleção de futuros atletas (SEDF, 2012a). Portanto, ainda que o CID pontualmente possibilite uma prática que direcione para atividades de alto 
rendimento com performance competitiva no âmbito do esporte de alto rendimento, como ocorre na unidade do CID onde atua o Professor 3, os resultados esportivos dos "atletas" de boa performance formados pelo CID têm, certamente, como destino a iniciativa privada, seja em clubes ou escolas privadas.

Uma intervenção pública do Estado na área de esporte educacional despreza o sentido democrático quando atua em favor de interesses particulares e privatistas. Isso se dá ao anúncio que a função desta política pública é o selecionamento esportivo e o beneficiamento de entidades privadas com a formação e especialização esportiva para atuação no campo esportivo controlado por interesses privados, possível culminância do trabalho do CID junto aos alunos mais habilidosos. Como o produto dessas experiências particulares não tange a esta pesquisa, mas sim os resultados do CID como política de esporte educacional, reforçamos o caráter seletivo e focalista presente nesta política, estas sim, características que impõe limites contundentes à consolidação de direitos de cidadania e, por conseguinte, à anunciada formação esportiva crítica. Ainda sobre os limites desta pesquisa, caberia como sugestão para novos trabalhos um maior aprofundamento nos resultados educacionais (anunciados e obtidos) perante os beneficiários do Projeto.

Outra ação possível para viabilizar a inserção definitiva do CID como uma ação de esporte educacional vinculada às escolas e, por conseguinte, o prenúncio de um caminhar no sentido da universalização, é sua inclusão nos PPPs das escolas. Mas, não somente universalizar, sim fazê-lo com qualidade programática e disposto a refleti-lo sob um um viés crítico, histórico e dialético, de forma a confrontar a perspectiva que hoje está posta da lógica piramidal, ideia que é mantida em sua vanguarda através dos braços do próprio $\mathrm{ME}$, como ente público e maior expressão e pelo $\mathrm{COB}$, ente privado de maior magnitude.

Por essa forma, é premente a construção de uma nova Orientação Pedagógica como uma instrução normativa e conceitual (tal como realizado para com os PPPs das Unidades Educacionais) que afirme definitivamente a inserção do Centro de Iniciação Esportiva no cotidiano escolar. O órgão de controle do Projeto CID (CEFDESC ou outro órgão que lhe valha ${ }^{99}$ ) deve problematizar essas questões aqui levantadas e, na perspectiva de descentralização da gestão, transferir a

99 Conforme anunciado anteriormente, a CEFDESC fora extinta em outubro de 2015 e o órgão que passou a administrar o CID no interior de SEDF fora a Gerência de Educação Física e Desporto Escolar. 
responsabilidade para as Unidades Educacionais construírem sua própria perspectiva de CID, agora sim atrelado às suas demandas e perspectivas. Essa iniciativa hipertrofia o sentido de esporte educacional e possibilita a entrada de novos atores na construção permanente e em movimento de um novo esporte educacional.

Apesar de todas essas características estruturais apontadas que fragilizam a perspectiva educacional e democrática do CID, é fundamental concluir essa dissertação enaltecendo seus recentes avanços que, conforme já anunciamos, podem sinalizar o início de uma virada histórica nesta política educacional. Inicialmente, é preciso destacar que a aproximação do Projeto CID aos Planos de Educação desenvolvidos pela SEDF como o Projeto Político-Pedagógico Institucional, o Currículo Oficial, a política de financiamento e os Projetos Políticos-Pedagógicos das Unidades Educacionais possibilita ao CID se aproximar dos direitos sociais, ainda que o direito ao esporte não se consigne como tal. E, ao aproximar-se de iniciativas como a concepção de Educação Integral no sentido de formação humana integralizada, possibilita a superação da concepção vulgarizada de esporte no contraturno escolar, a qual secundariza e subjuga as potencialidades educativas emancipatórias do esporte.

O referido arcabouço normativo e institucional confere ao CID a possibilidade de se reconhecer como uma política educacional e, de tal forma, seu fomento e desenvolvimento passam a obter maior garantia. $O$ financiamento através da política do PDAF no ano de 2015, por exemplo, significou para o Gestor 3 que o atual governo do DF (mandato Rodrigo Rollemberg) e a SEDF valorizam e prestigiam esta política, mesmo com o severo contingenciamento de despesas do atual mandato.

O modelo histórico de gestão proposto para o Projeto fragilizava sua perspectiva democrática, como exemplo vide a questão do financiamento incerto e pontual, não normatizado. Ainda que nesta pesquisa não se tenha aprofundado no direcionamento dos gastos, ou ampliado o espectro de análise para se verificar quantitativamente a relação entre estes e o benefício dos estudantes, demonstrou-se que historicamente o Projeto esteve abandonado a iniciativa dos docentes, com a presença tão somente na perspectiva do controle, fiscalização, fomento e ampliação. A segurança jurídicoinstitucional que seus trabalhadores têm vivenciado por meio do concurso de remanejamento representou um enorme avanço por regulamentar sua vida funcional e garantir direitos que apetecem a todo magistério público, mas ao docente do CID 
era incerto e/ou fragilizado como aposentadoria especial, férias, abonos, licenças médicas.

Já o PDAF, que ocorre neste ano de 2015 pela segunda vez, possibilitou ao CID, de forma concomitante, uma isonomia de tratamento às demais atividades do cotidiano escolar e uma autonomia para ajustar-se e planejar-se financeiramente, adquirindo novos materiais para a prática das aulas, financiando inscrições, transporte e alimentação de estudantes para participação em competições, ampliando sua experiência esportiva e socioeducativa através das atividades propostas para o CID.

Essas ações articuladas também possibilitam a ampliação das instâncias de controle social do CID em face a inserção de novos atores na concepção, controle e execução de suas atividades, em especial o Conselho Escolar e a Assembleia Escolar. Esses atores, descritos no capítulo anterior são, potencialmente, sujeitos primordiais para que o CID possa se fortalecer como uma política de esporte educacional.

Cabe destacar ainda que a presença ampla da Sociedade Civil possibilita um debate mais profícuo para se pensar e conceber um novo viés para esta política. É fundamental, portanto, trazer para o debate ampliado não apenas instituições ligadas ao esporte institucionalizado ou às comunidades escolares, mas também entes da Sociedade Civil que possuam acúmulo e propostas interventivas na área do esporte, lazer e educação. De forma a compreender qual o sentido desse processo, é sempre importante alimentar-se da concepção de Pereira (2008a), a qual afirma que o interesse público deve prevalecer na concepção das políticas. E afrontar de forma franca e qualificada a reprodução da tendência mercantilista e utilitarista, já hegemonizadas pelos interesses privatistas do alto setor esportivo e referenciada pelo discurso raso acerca de educação e de esporte que se apresentam no âmbito do Estado, conforme ficou expresso nos últimos PPAs do Governo do Distrito Federal.

Ao final, colocados os limites da pesquisa e somando-os aos limites do pesquisador no esforço para compreender o que o CID é, e o que lhe é possível vir a ser, acredito que é chegada a hora de construir uma nova história. Novas pesquisas podem suscitar-se a partir das ponderações aqui levantadas e não respondidas tais como aprofundar na aferição e análise dos resultados quantitativos e qualitativos das gestões que tangeram ao financiamento, controle social e inserção nas políticas educacionais, ou ainda avaliar a amplitude das ações voltadas à perspectiva 
educacional, enfatizadas na história recente do CID, ou, quem sabe, repercutir a formação docente (inicial e continuada) junto aos resultados de sua intervenção pedagógica (se tende ao reprodutivismo ou à criticidade, por exemplo).

A bússola da história tem apontado, enfim, que os estudantes do Distrito Federal têm à sua mão um potencial satisfador de suas necessidades básicas. Ainda que se apresente no cenário histórico contemporâneo uma nítida guerra de posições entre a barbárie e a humanização, entre as perspectivas reacionário-conservadoras e a ampliação de direitos sociais, as possibilidades democráticas e humanizadoras do Projeto CID têm se apresentado de forma premente através dos recentes avanços. A busca pela emancipação através do esporte educacional, enfim, já começou. 


\section{Referências}

ANDERSON, P. Balanço do Neoliberalismo in SADER, E.; GENTILI, P. (orgs.). PósNeoliberalismo: as políticas sociais e o Estado democrático. Rio de Janeiro: Paz e Terra, 1995.

ANTUNES, R. Adeus ao trabalho? : ensaios sobre as metamorfoses e centralidade do mundo do trabalho. 15 a ed. São Paulo: Cortez, 2011.

ATHAYDE, P. F. A. O "lugar social” na Política de Esporte do Governo Lula. SER Social, Brasília, v. 13, n. 28, p. 184-209, jan./jun. 2011

O ornitorrinco de chuteiras: determinantes econômicos da política de esporte do governo Lula e suas implicações sociais. Tese de doutorado apresentada ao Programa de Pós-graduação em Política Social do Departamento de Serviço Social da Universidade de Brasília. Brasília, DF, 2014.

BEHRING, E. R e. BOSCHETTI, I. Política social: fundamentos e história. São Paulo: Cortez, $20119^{\mathrm{a}}$ ed. $4^{\mathrm{a}}$ reimp.

BEHRING, E. R. Política Social no capitalismo tardio. 4. Ed. São Paulo: Cortez, 2009.

BELTRAME, A. L. N. Centro de iniciação desportiva paraolímpica no Distrito Federal: um estudo na ótica da educação inclusiva. Dissertação de Mestrado apresentada à Universidade Católica de Brasília. Brasília, DF; 2013.

BETTI, M. Educação Física e sociedade. São Paulo: Editora Movimento, 1991.

BOSCHETTI, I. Avaliação de políticas, programas e projetos sociais. in: Serviço Social: Direitos Sociais e competências profissionais, CFESS, Brasilia, 2009.

BRACHT, V. A constituição das teorias pedagógicas da Educação Física. Caderno CEDES, 1999.

2005. Sociologia crítica do esporte: uma introdução. 3. Ed. ljuí: ed. Unijuí, 30 anos do CBCE: os desafios para uma associação científica. Rev. Bras. Cienc. Esporte, Campinas, v. 30, n. 3, p. 31-44, 2009.

BRACHT, V. e ALMEIDA, F. Q. A política de esporte escolar no Brasil: a pseudo valorização da Educação Física. Ver. Bras. Cienc. Esporte, Campinas. V. 14, n. 3, p. 87-101, maio 2003.

Esporte, escola e a tensão que os megaeventos esportivos trazem para a Educação Física Escolar. Em Aberto, v. 26, n. 89, p. 131-143, jan./jun. Brasília, DF: 2013.

BRASIL. Constituição da República Federativa do Brasil. Brasília, DF: 1988. 
Lei de diretrizes e Bases da Educação Nacional. Brasília, DF: 1996.

Disponível em < http://portal.mec.gov.br/arquivos/pdf/ldb.pdf>. Acesso em:

$16 / 06 / 2015$.

. Lei $\mathbf{N}^{\circ} \mathbf{9 . 6 1 5}$ de 24/03/1998. Disponível em <

http://www.planalto.gov.br/ccivil 03/LEIS/L9615consol.htm>. Acesso em 17/09/2015.

Decreto $N^{\circ} 7.984$ de 08/04/2013. Disponível em <

http://www.planalto.gov.br/ccivil 03/ Ato2011-2014/2013/Decreto/D7984.htm>.

Acesso em: 30/08/2015

BUENO, L. Políticas públicas de esporte no Brasil: razões para o predomínio do alto rendimento. Tese de doutorado. Escola de Administração de Empresas de São Paulo FGV, São Paulo, 2008.

CANCIONEIRO da cultura afro-brasileira.

CARNEIRO, F.H.S. A política de esporte no Distrito Federal: Centros Olímpicos, terceiro setor e focalização. Dissertação de Mestrado apresentada à Faculdade de Educação Física da Universidade de Brasília. Brasília, 2013.

CASTELAN, L. P As conferências nacionais do esporte na configuração da política esportiva e de lazer no governo Lula (2003-2010). Dissertação de mestrado apresentada à Faculdade de Educação Física da Universidade Estadual de - Campinas, SP: 2011.

CASTELLANI FILHO, L. Educação Física no Brasil: a história que não se conta. Campinas, SP: Papirus, 1988.

A Educação Física no sistema educacional brasileiro: percurso, paradoxos e perspectivas. Tese de Doutorado em Educação apresentado à Universidade Estadual de Campinas. Campinas, SP, 1999.

CASTELLANI FILHO, L. (org.) Gestão pública e política de lazer: a formação de agentes sociais. Campinas, SP: Autores Associados; São Paulo, 2007.

CASTELLANI FILHO, L. O Estado Brasileiro e os Direitos Sociais: O Esporte. In: HÚNGARO, Edson Marcelo; DAMASCENO, Luciano Galvão; GARCIA, Carla Cristina (Orgs.). Estado, política e emancipação humana: lazer, educação, esporte e saúde como direitos sociais. Santo André, SP: Alpharrabio, 2008, p. 129144.

. 25 anos de nossa Carta Magna e o esporte brasileiro:

temos o que comemorar? Universidade do Futebol, 2013. Disponível em $<$ http://www.universidadedofutebol.com.br/Coluna/12304/25-anos-de-nossa-CartaMagna-e-o-esporte-brasileiro-temos-o-que-comemorar> Acesso em: 15/05/2014.

COLETIVO DE AUTORES. Metodologia do Ensino de Educação Física. São Paulo, SP, Cortez, 1992.

COUTINHO, C.N. Notas sobre cidadania e modernidade. In: Perspectiva, n. 22, p. 41-59. São Paulo, SP: 1999. 
O leitor de Gramsci: escritos escolhidos 1916-1935. Organização e Introdução de Carlos Nelson Coutinho. Rio de Janeiro: Civilização Brasileira, 2011.

COTTA, T. C. Metodologia de avaliação de programas e projetos sociais: análise de resultados e de impacto. Revista do Serviço Público: ano 49, N. 02, p. 103-124. Abr-jun 1998. Disponível em http://repositorio.enap.gov.br/handle/1/1634. Acesso em 22/09/2015.

DAMASCENO, L. G. 30 Anos do Colégio Brasileiro de Ciências do Esporte: Educação Física e a construção de uma hegemonia. Dissertação de Mestrado apresentada à Faculdade de Educação Física da Universidade Estadual de Campinas. Campinas, SP: 2011.

DAÓLIO, J. Educação Física escolar: em busca da pluralidade. Rev. paul. Educ. Fís., São Paulo, supl.2, p.40-42, 1996.

DISTRITO FEDERAL. Lei Orgânica do Distrito Federal. Brasília, DF: Câmara Legislativa do Distrito Federal, 1993.

Lei $N^{\circ} 4.007$, de 20 de agosto de 2007. Diário Oficial do Distrito Federal No 161 de 21/08/2007.

.Edital No 1 do Concurso Público 1/2008 - SEDEST, de 15 de dezembro de 2008. Diário Oficial do Distrito Federal No250, Seção III, de $17 / 12 / 2008$.

Federal No 250, Seção I de 30/12/2011

. Lei № 4.742 de 29/12/2011. Diário Oficial do Distrito

Portaria Conjunta PMDF/SEDF Nº 5 de 01/04/2014. Diário

Oficial do Distrito Federal №66, Seção I de 02/04/2014.

DUARTE, R. Entrevistas em pesquisa qualitativas. Educar, Curitiba, n. 24, p. 213225, Editora UFPR: Curitiba-PR, 2004. Disponível em

<http://www.scielo.br/pdf/er/n24/n24a11.pdf> Acesso: 03/08/2015

FIGUEIREDO, P.O.F.N. Política e formação : o Programa Esporte e Lazer da Cidade no Distrito Federal e Entorno. Dissertação de Mestrado apresentada ao Programa de Pós-graduação da Faculdade de Educação Física da UnB. Brasília, DF: 2009

FILGUEIRA, D. e FERES NETO, A. (orgs.). Esporte e Lazer: a cidadania em construção. Brasília: Thesaurus, 2012.

FLAUSINO, M da S. e MASCARENHAS, F. O direito ao esporte e lazer:

apontamentos críticos à sua mistificação. Licere, Belo Horizonte, v.15, n.2, jun/2012.

GARCIA, R.C. PPA: o que não é e o que pode ser. In: Planejamento e avaliação de políticas públicas. CARDOSO JR., J.C. e CUNHA, A dos S. (orgs.). Brasília: 
IPEA, 2015. Disponível em

$<$ http://www.ipea.gov.br/portal/images/stories/PDFs/livros/livros/livro ppa vol 1 web .pdf> Acesso: 07/08/2015.

GIL, A. C. Métodos e técnicas de pesquisa social. 6ª ed. São Paulo: Atlas, 2008.

GONZÁLEZ, F.J. Esportivização. In: GONZÁLEZ, F.J. e FENSTERSEIFER, P.E. Dicionário Crítico de Educação Física. ljuí: Ed . Unijuí, 2005. p. 170-173.

GUIRRA, F.J.S. V Jogos Mundiais Militares no Brasil e a reinserção do esporte militar na política esportiva nacional. Tese de doutorado apresentado à Faculdade de Educação Física da Universidade Estadual de Campinas. Campinas SP: 2014

HÚGARO, E.M. Trabalho, tempo livre e emancipação humana: os determinantes ontológicos das políticas sociais de lazer. Tese de doutorado apresentado à Universidade Estadual de Campinas - UNICAMP. Campinas, SP: 2008

KOSIC, K,. Dialética do concreto; tradução de Célia Neves e Alderico Toríbio. Rio de Janeiro, Paz e Terra, 1976.

LIÁO JR., R. Hegemonia e contra-hegemonia na construção de políticas de Esporte e Lazer: a experiência do Consórcio Brasília. Tese de doutorado apresentada à Faculdade de Educação Física da Universidade Estadual de Campinas. Campinas - SP: 2013.

LIGGIERI, N. Seletividade e distinção no esporte: um estudo da Centro de Iniciação Desportiva (CID) no contexto da Educação Física em escolas públicas de Ceilândia, no Distrito Federal (DF). Dissertação de Mestrado apresentada à Faculdade de Educação Física da Universidade de Brasília. Brasília - DF, 2014.

LINHALES, M. A. A trajetória política do esporte no Brasil: interesses envolvidos, setores excluídos. Dissertação de Mestrado apresentado a Faculdade de Filosofia e Ciências Humanas da UFMG. Belo Horizonte, MG, 1996.

MANHÃES, E. D. Política de esporte no Brasil. 2. Ed. Rio de Janeiro: Paz e Terra, 2002.

MARX, K. Introdução à crítica da economia política. 1859. Disponível em $<$ http://www.histedbr.fae.unicamp.br/acer fontes/acer marx/tme 15.pdf> Acesso: $13 / 05 / 2014$

Manuscritos econômicos e filosóficos e outros textos escolhidos. 5 . ed. - São Paulo: Nova Cultural, Coleção Os pensadores, 1991.

O Capital: crítica da economia política: livro I. $33^{a}$ edição. Tradução de Reginaldo Sant'Anna. Rio de Janeiro: Civilização Brasileira, 2014. MASCARENHAS, F. Entre o ócio e o negócio: teses acerca da anatomia do lazer. Tese de doutorado apresentado à Faculdade de Educação Física da Universidade Estadual de Campinas. Campinas, SP: 2005. 
. O Estado Brasileiro e os direitos sociais: o lazer. In:

HÚNGARO, Edson Marcelo; DAMASCENO, Luciano Galvão; GARCIA, Carla

Cristina (Orgs.). Estado, política e emancipação humana: lazer, educação, esporte e saúde como direitos sociais. Santo André, SP: Alpharrabio, 2008, p. 95 114.

Megaeventos esportivos e Educação Física: alerta de tsunami. Porto Alegre, RS: Movimento, v. 18, n. 01, p. 39-67, 2012.

MATIAS, W. O enigma olímpico: o controvertido percurso da agenda e políticas esportivas do governo Lula. Dissertação de Mestrado apresentada ao Programa de Pós-graduação da Faculdade de Educação Física da UnB. Brasília, DF: 2013

Política social de esporte e lazer no governo Lula: o Programa Esporte e Lazer da Cidade. SER Social, Brasília, v. 16, n. 34, p. 134-161, jan.jun./2014

MÉZÁROS, I. A educação para além do capital. 2. ed. - São Paulo: Boitempo, 2008.

MONTAÑO, C. Terceiro setor e questão social: crítica ao padrão emergente de intervenção social. 6. Ed. São Paulo: Cortez, 2010.

MONTAÑO, C.; DURIGUETTO, M. L. Estado, classe e movimento social. São Paulo: Cortez, 2010.

NATIRUTS. Quero ser feliz também. Rio de Janeiro: Sony Music, 2012. 1 CD e 1 DVD.

NEGRÃO, J. J. O consenso de Washington. In: Para conhecer o Neoliberalismo. Publisher Brasil, 1998. Disponível em

<http://www.cefetsp.br/edu/eso/globalizacao/consenso.html>. Acesso: 16/05/2014.

NEVES, A. V. Espaços públicos participativos, construção democrática e políticas públicas: riscos de despolitização da participação da sociedade civil na cultura política brasileira. In: Ser Social. Brasília, SER Social UnB, 2005: p. 197-218.

OLIVEIRA, B.A. e HÚNGARO, E.M. Esporte e lazer como direitos sociais e a ofensiva neoliberal: primeiras aproximações in: SOLAZZI, J.L e RODRIGUES, J. P. Neoliberalismo e políticas de lazer: apontamentos críticos: 5 anos de pesquisa do Observatório de Políticas Sociais de Educação Física, Esporte e Lazer. Santo André, SP: Alpharrabio, 2008. P. 33-44

PAULO NETTO, J. Marxismo impenitente: contribuição à história das ideias marxistas. São Paulo: Cortez, 2004.

- Introdução ao estudo do método de Marx. São Paulo:

Expressão Popular, 2011. 
. O leitor de Marx. Rio de Janeiro: Civilização Brasileira, 2012.

PEREIRA, P. A. P. Discussões conceituais sobre política social como política pública e direito de cidadania. Em: BOSCHETTI, I.; BEHRING, E. R.; SANTOS, S. M. M.; MIOTO, R. C. T. Política social no capitalismo: tendências contemporâneas. São Paulo: Cortez, 2008a. p. 87-108

Necessidades humanas: subsídio à crítica dos mínimos sociais.

5. ed. São Paulo: Cortez, 2008b

. Porque também sou contra a focalização das políticas públicas.

Disponível em <http://www.neppos.unb.br/publicacoes/contra focal.pdf> Acesso:

12/02/2015). Núcleo de Estudos e Pesquisas em Política Social. Brasília, UnB.

Política social: temas \& questões. 3. Ed. São Paulo: Cortez,

2011.

PEREIRA, P.A. P. e STEIN, R. H. Política Social: Universalidade versus focalização. Um olhar sobre a América latina. In: BOSCHETTI, I. et. al. (orgs.): Capitalismo em crise, política social e direitos. São Paulo: Cortez, 2010. p. 106 a 130

PIRES, G. L.; SILVEIRA, J. Esporte educacional ... existe? Tarefa e Compromisso da Educação Física com o esporte na escola. In: SILVA, M. R. (Org.) Esporte, educação, estado e sociedade: as políticas públicas em foco. Chapecó: Argos, 2007.

QUIRINO, M. G et. al. Proposta de Avaliação dos Centros de Iniciação Desportiva (CID) no Distrito Federal com base na metodologia MCDA. Disponível em <http://www.abepro.org.br/biblioteca/ENEGEP2012_TN_STO_167_969_20671.pdf>. Acesso em 09/05/2014

RIBEIRO JR., A. et al. O lado sujo do futebol: a trama de propinas, negociatas e traições que abalou o esporte mais popular do mundo. São Paulo: Planeta, 2014.

RUA, M. da G. Análise de Políticas Públicas: Conceitos Básicos. Disponível em<http://webcache.googleusercontent.com/search?q=cache:WI81p2KN3nUJ:portal .mda.gov.br/o/1635738+\&cd=1\&hl=pt-BR\&ct=clnk\&gl=br>. Acesso: 29/10/2015.

Brasília, 2012.

SADER, E. Estado e política em Marx. São Paulo: Boitempo, 2014.

SAMPAIO, J.O. A Educação Física e a perspectiva histórico-cultural: as apropriações de Vigotski pela produção acadêmica da área. Dissertação de Mestrado apresentada à Faculdade de Educação Física da Universidade de Brasília. Brasília, DF, 2013.

SECRETARIA DE ESTADO DE EDUCAÇÃO DO DISTRITO FEDERAL. Orientação Pedagógica Centro de Iniciação Desportiva. Brasília, DF, 2012a 
Projeto

Político-Pedagógico Professor Carlos Mota. Brasília-DF, 2012b. Portaria $\mathbf{N}^{\circ}$

71 de 09 de abril de 2013.

Currículo

em Movimento da Educação Básica. Brasília, 2014a. Projeto

Cidade Escola Candanga: Educação Integral. Brasília, 2014b.

SERON, T.D. Reflexões sobre o desporto escolar a partir do decreto $\mathbf{N}^{\circ}$

7.984/2013. Revista da ASLEDE, Curitiba - PR, v.3 n. 2, p. 31-45, outubro/2013.

SIMÕES, C. Teoria \& crítica dos direitos sociais: o Estado social e o Estado democrático de direito. São Paulo: Cortez, 2013.

SINGER, A.V. Os sentidos do lulismo: reforma gradual e pacto conservador. $1^{\text {a } e d ., ~}$ $1^{\mathrm{a}}$ reimpressão. São Paulo: Companhia das Letras, 2012.

SOUZA, Carlos Eduardo de. A formação do Estado capitalista no Brasil e a institucionalização do esporte na aparelhagem estatal: entre os anos de 1930 a 1990. Anais Eletrônicos do IX Seminário Nacional de Estudos e Pesquisas "História, Sociedade e Educação no Brasil". UFPB, João Pessoa - PB, 2012. Disponível em: $<$ http://www.histedbr.fae.unicamp.br/acer histedbr/seminario/seminario9/PDFs/2.79. pdf> Acesso: 15/05/2014

STAREPRAVO, F. A. Políticas públicas de esporte e lazer no Brasil: aproximações, intersecções, rupturas e distanciamentos entre os subcampos político/burocrático e científico/acadêmico. Tese de doutorado apresentada no Departamento de Educação Física, Setor de Ciências Biológicas da UFPR. Curitiba, PR: 2011.

TAFFAREL, N.C.Z. Desporto educacional: realidade e possibilidade das políticas governamentais e das práticas pedagógicas nas escolas públicas. Movimento, v. 6 , $\mathrm{N}^{\circ} 13$, p. 15 a 35, 2000. Disponível em:

$<$ http://www.seer.ufrgs.br/index.php/Movimento/article/view/11788/6986>. Acesso em 01/04/2014.

TAVARES, O. Olimpismo. In: GONZÁLEZ, F.J. e FENSTERSEIFER, P.E.

Dicionário Crítico de Educação Física. ljuí: Ed . Unijuí, 2005: p. 305-307.

TONET, I. Cidadania ou emancipação humana? Espaço Acadêmico, n. 44, 2005. Disponível em $<$ http://ivotonet.xpg.uol.com.br/arquivos/CIDADANIA OU EMANCIPACAO HUMAN A.pdf>Acesso: 03/03/2015

TRIVIÑOS, A. N. S. Introdução à pesquisa em ciências sociais: a pesquisa qualitativa em educação. $1^{\mathrm{a}}$ ed. $-17^{\mathrm{a}}$ reimpr. - São Paulo: Atlas, 2008. 
TUBINO, M. J. G. As dimensões sociais do esporte. São Paulo: Cortez/Autores Associados, 1992.

Estudos brasileiros sobre o esporte: ênfase no esporte educação. Maringá: Eduem, 2010.

VERONEZ, Luiz Fernando Camargo. Quando o Estado joga a favor do privado: as políticas de esporte após a Constituição de 1988. 2005. 386 f. Tese (Doutorado em Educação Física) - Faculdade de Educação Física. Universidade Estadual de Campinas, Campinas, 2005.

VIEIRA, E. Os direitos e a política social. 3. ed. São Paulo: Cortez, 2009. 


\section{APÊNDICE I}

\section{ROTEIRO DE ENTREVISTAS}

\section{ROTEIRO DE ENTREVISTA I - Gestores do Projeto}

1- Quem são as pessoas beneficiadas pelo projeto? Quais são as Regiões administrativas onde funcionam o CID?

2- Como é atualmente o acesso ao CID?

3- Quais são os critérios utilizados para ampliar o CID no que concerne à seleção de professores, seleção de modalidades, locais de execução? Quais são as ações que a SEDF precisa tomar para que isso seja garantido?

4- Como se dá o controle do CID sobre as ações pedagógicas dos professores?

5- Como é financiado o Projeto? Quais são os caminhos legais, normativos e políticos para se alcançar esse financiamento?

6- Qual o valor estimado de gasto per capita por unidade de CID? Como são direcionados os gastos desse financiamento?

7- Qual articulação o CID estabelece com outras políticas da SEDF? E com políticas de outras esferas governamentais?

8- Há alguma participação e/ou influência dessas esferas governamentais na construção do projeto pedagógico do CID?

9- Quais pessoas ou instituições têm acesso aos instrumentos de execução ou avaliação das ações do CID? Que tipo de ações esses personagens podem exercer?

10-Qual a infraestrutura material, física ou de recursos humanos o SEDF disponibiliza para o funcionamento do CID?

11-Em sua opinião, quais são as diferenças quantitativas e qualitativas encontradas no Projeto CID nos últimos 3 anos (sob a planejamento do último PPA)?

ROTEIRO DE ENTREVISTA II - Gestores das Unidades Educacionais

1- Quantos estudantes são matriculados no CID que funciona Esta Unidade Educacional? Os estudantes são apenas desta escola? De que outras escolas são? Qual a proporcionalidade? Há somente uma unidade do CID em sua escola? Quais outros?

2- O CID é divulgado em sua escola? A comunidade escolar conhece o Projeto? Eles têm acesso ao CID?

3- $O$ CID que funciona nesta escola se articula com outras instituições educacionais, não-educacionais, públicas ou privadas? Quais e de que forma?

4- De que forma o CID nesta escola se articula com as aulas de Educação Física? 
5- Há algum financiamento para esta unidade do CID? Em caso afirmativo, o Sr. (Sra.) pode descrever o valor e o direcionamentos do gastos desse financiamento?

6- Quem executa este financiamento?

7- Quais pessoas ou instituições têm acesso aos instrumentos de execução ou avaliação das ações do CID nesta escola? Que tipo de ações esses personagens podem exercer?

8- Qual a infraestrutura material, física ou de recursos humanos a escola disponibiliza para o funcionamento do CID?

9- Em sua opinião, quais são as diferenças quantitativas e qualitativas encontradas no Projeto CID nos últimos 3 anos (sob a planejamento do último PPA)?

\section{ROTEIRO DE ENTREVISTA III - Professores(as)}

1- Quantos alunos o Sr.(Sra.) atende em seu pólo? Quem são esses alunos (faixa etária, gênero, escola de origem, quantidade de atendimentos)?

2- Como ao Sr.(à Sra.) foi possibilitado a atuação no CID? Há quanto tempo atua? Quais suas atribuições além da sala de aula e como as exerce?

3- Que articulações sua aula estabelece com outras instituições educacionais, não-educacionais, públicas ou privadas? Quais e de que forma? E com outras unidades do CID?

4- Há alguma espécie de financiamento direto ou indireto à sua unidade do CID? O Sr. (Sra.) pode descrever o valor e o direcionamento dos gastos deste financiamento?

5- Quais pessoas ou instituições têm acesso aos instrumentos de execução ou avaliação das ações do CID nesta escola? Que tipo de ações esses personagens podem exercer?

6- Qual a infraestrutura física, material e de recursos complementares o Sr. (Sra.) tem acesso? Acredita que é adequada para o cumprimento das funções do Projeto CID, de acordo com a OP?

7- Em sua opinião, quais são as diferenças quantitativas e qualitativas encontradas no Projeto CID nos últimos 3 anos (sob a planejamento do último PPA)? 


\title{
APÊNDICE II - TERMO DE CONSENTIMENTO LIVRE E ESCLARECIDO
}

\author{
$\underbrace{}_{\mathrm{UnB}}$ \\ Universidade de Brasília \\ Faculdade de Educação Física \\ Programa de Pós-Graduação em Educação Física
}

Termo de Consentimento Livre e Esclarecido - TCLE

Convidamos o(a) Senhor(a) a participar do projeto de pesquisa "O esporte educacional no contexto das políticas esportivas do Distrito Federal: uma proposta de análise do Projeto Centro de Iniciação Desportiva (CID)", sob a responsabilidade do pesquisador Samir Almeida Santos. O projeto tem como objetivo avaliar e analisar a experiência do Projeto CID como uma política de esporte educacional no Distrito Federal, inserindo-o no contexto das demais políticas esportivas e avaliando suas características frente ao que estipulam os preceitos constitucionais e normativos para as políticas de esporte educacional.

O objetivo desta pesquisa é, portanto, analisar e avaliar a experiência do CID no Distrito Federal, buscando compreender seu modelo conceitual, a concepção dessa política e seu modelo de gestão.

$\mathrm{O}(\mathrm{a})$ senhor(a) receberá todos os esclarecimentos necessários antes e no decorrer da pesquisa e lhe asseguramos que seu nome não aparecerá sendo mantido o mais rigoroso sigilo pela omissão total de quaisquer informações que permitam identificá-lo(a)

A sua participação se dará por meio de uma entrevista semiestruturada, onde um roteiro prévio de perguntas foi elaborado. A entrevista será gravada em áudio e será transcrita por este pesquisador. A entrevista será realizada em seu ambiente de trabalho na data combinada, com um tempo máximo estimado de uma hora para sua realização em uma única visita.

Segundo o item V da Res. CNS 466/2012: "Toda pesquisa com seres humanos envolve risco em tipos e gradações variados." e "Il.22 - risco da pesquisa - possibilidade de danos à dimensão física, psíquica, moral, intelectual, social, cultural ou espiritual do ser humano, em qualquer pesquisa e dela decorrente". Para minimizar esses riscos, que no procedimento de pesquisa (entrevista) possam trazer ao $\mathrm{Sr}(\mathrm{a})$ constrangimento, insegurança, desconforto, ou ansiedade por se sentir vítima de preconceito ou discriminações, o pesquisador responsável procurará contornara situação de forma cordial, preservando a identidade e sigilo do entrevistado(a) e do conteúdo da entrevista, além permitir imediatamente ao Sr.(Sra.) total acesso ao conteúdo da entrevista (gravada, transcrita como analisada).

Todas as despesas que você tiver relacionadas diretamente ao projeto de pesquisa (passagem para o local da pesquisa, alimentação no local da pesquisa ou exames para realização da pesquisa) serão cobertas pelo pesquisador responsável.

Caso haja algum dano direto ou indireto decorrente de sua participação na pesquisa, você poderá ser indenizado, obedecendo-se as disposições legais vigentes no Brasil, conforme os itens IV.3, subitens g e h, e IV.4.c, da Res. CNS 466/2012. 
Se o Sr. (Sra.) aceitar participar, estará contribuindo para o fortalecimento do direito ao esporte educacional do Distrito Federal. O(a) Senhor(a) pode se recusar a responder qualquer questão que lhe traga constrangimento, podendo desistir de participar da pesquisa em qualquer momento sem nenhum prejuízo para o(a) senhor(a). Sua participação é voluntária, isto é, não há pagamento por sua colaboração.

Os resultados da pesquisa serão divulgados no repositório institucional da Universidade de Brasília, podendo ser publicados em Periódicos Científicos posteriormente. Os dados e materiais utilizados na pesquisa ficarão sob a guarda do pesquisador por um período de no mínimo cinco anos, após isso serão destruídos ou mantidos na instituição.

Se o(a) Senhor(a) tiver qualquer dúvida em relação à pesquisa, por favor telefone para: Samir Almeida Santos, na Faculdade de Educação Física da Universidade de Brasília nos telefones $61.3107-2252,61.8447-2627$, de segunda a sexta-feira no horário de $08 \mathrm{~h}$ às $18 \mathrm{~h}$, ou o prof. Orientador desta pesquisa, Dr. Fernando Mascarenhas nos telefones 61. 3107-2252 ou 61.8175-1172 nos mesmos horários.

Este projeto foi Aprovado pelo Comitê de Ética em Pesquisa da Faculdade de Ciências da Saúde (CEP/FS) da Universidade de Brasília. O CEP é composto por profissionais de diferentes áreas cuja função é defender os interesses dos participantes da pesquisa em sua integridade e dignidade e contribuir no desenvolvimento da pesquisa dentro de padrões éticos. As dúvidas com relação à assinatura do TCLE ou os direitos do participante da pesquisa podem ser obtidos através do telefone: (61) 3107-1947 ou do e-mail cepfs@unb.br ou cepfsunb@gmail.com, horário de atendimento de $10 \mathrm{hs}$ às $12 \mathrm{hs}$ e de $13 \mathrm{~h} 30 \mathrm{~m}$ às $15 \mathrm{~h} 30 \mathrm{~m}$, de segunda a sexta-feira.

Este documento foi elaborado em duas vias, uma ficará com o pesquisador responsável e a outra com o Senhor(a).

Nome / assinatura

Pesquisador Responsável

Samir Almeida Santos

Brasília, de de 


\section{APENDICE III - TERMO DE AUTORIZAÇÃO PARA UTILIZAÇÃO DE SOM DE VOZ PARA FINS DE PESQUISA}

$\mathrm{Eu}$, _ autorizo a utilização de meu som de voz, na qualidade de participante/entrevistado(a) no projeto de pesquisa intitulado "O esporte educacional no contexto das políticas esportivas do Distrito Federal: uma proposta de análise do Projeto Centro de Iniciação Desportiva (CID)", sob responsabilidade de Samir Almeida Santos vinculado(a) ao Programa de Pós-Graduação da Faculdade de Educação Física da universidade de Brasília.

Meu som de voz pode ser utilizado apenas para análise do pesquisador e sua posterior transcrição/reprodução no(s) trabalho(s) oriundos desta pesquisa como a Dissertação de Mestrado, apresentações em conferências profissionais e/ou acadêmicas, atividades educacionais, etc.

Tenho ciência de que não haverá divulgação de meu som de voz por qualquer meio de comunicação, sejam elas televisão, rádio ou internet, exceto nas atividades vinculadas ao ensino e a pesquisa explicitadas acima. Tenho ciência também de que a guarda e demais procedimentos de segurança com relação aos sons de voz são de responsabilidade do pesquisador responsável.

Deste modo, declaro que autorizo, livre e espontaneamente, o uso para fins de pesquisa, nos termos acima descritos, de meu som de voz.

Este documento foi elaborado em duas vias, uma ficará com o(a) pesquisador(a) responsável pela pesquisa e a outra com o(a) participante.

Assinatura do (a) participante

Assinatura do (a) pesquisador (a)

Brasília, de de 


\title{
ANEXO I - CARTA DE APROVAÇÃO DO COMITÊ DE ÉTICA EM PESQUISA DA $\mathrm{FS} / \mathrm{UnB}$
}

\author{
stom \\ Unvervitade de B.aslia \\ Facultiule de Ciéncias da Sariche \\ Comic de fulica em Pesquisil Ci.Pils \\ PROCESSO DE ANALISE DE PROJETO DE PESQUISA
}

Titulo do Prijeto: 0 ESPORTT. TDDTCACIONAL NO CONTEXTY DAS HOLFTTCAS ESIPORLIVAS DO DISTRITO FEIDIRAI: IMA PROPOSTA DI: ANAITSE DO PROITTO CTNTTRO DE INICIACÄO DTSPORTIVA (CIT)".

Pesquisadora Roxpmoxivcl: SAMIR ALMEIDA SANTOS

Data de Entrada: 09703;2015

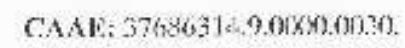

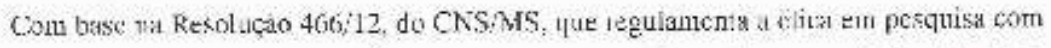
scres humanus, o Conie de Étice em Pesquisa com Seres Humanos da Ficulatate de

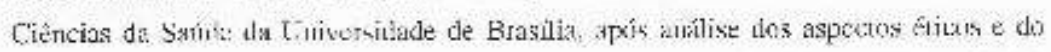

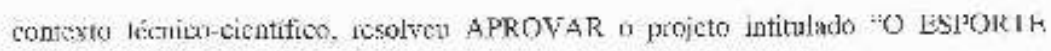
EDUTCACIONAL NO CONIEXIO DAS POLITICAS ISPCIRIIVAS DO DISTRTTO FEDERAL: UMA PROPOSTA LE ANÁLIST: DO PROJEIU CENTRO DI!

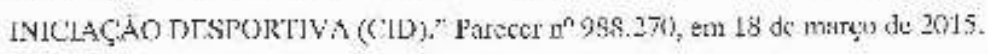

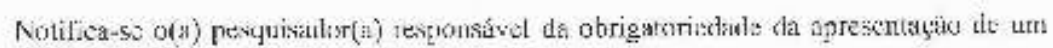

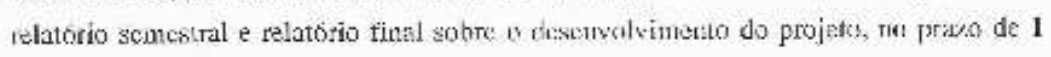
(um) ancs a contar da dare de aprovitŭăt.

Brasilia, 23 de marox du: 201 .

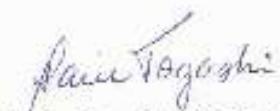

Profa. Dra. Maric Togashi

Coordonador do CEP-FSiUnB 